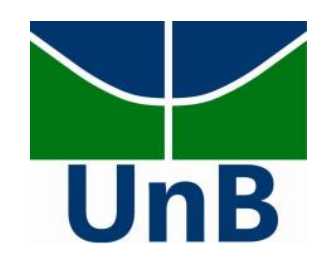

UNIVERSIDADE DE BRASÍLIA - UnB

FACULDADE DE PLANALTINA - FUP

PROGRAMA DE PÓS-GRADUAÇÃO EM GESTÃo PÚBLICA - PPGP MESTRADO PROFISSIONAL EM GESTÃO PÚBLICA

\title{
A COMISSÃO DE ÉTICA COMO PRÁTICA EDUCATIVA: O CASO DA UNIVERSIDADE DE BRASÍLIA
}

PRISCILLA KETTILYN ROSA DE FRANÇA SOUSA

BRASÍLIA - DF 
PRISCILLA KETTILYN ROSA DE FRANÇA SOUSA

\title{
A COMISSÃO DE ÉTICA COMO PRÁTICA EDUCATIVA: O CASO DA UNIVERSIDADE DE BRASÍLIA
}

\author{
Dissertação apresentada ao Programa de Pós- \\ Graduação em Gestão Pública, para conclusão do \\ Mestrado Profissional em Gestão Pública da \\ Faculdade de Planaltina da Universidade de Brasília, \\ como requisito para obtenção do título de Mestre em \\ Gestão Pública.
}

Orientadora: Andréa de Oliveira Gonçalves

BRASÍLIA - DF 
S725c Sousa, Priscilla Kettilyn Rosa de França.

A Comissão de Ética como prática educativa: o caso da Universidade de Brasília / Priscilla Kettilyn Rosa de França Sousa. - 2015.

223 f. : il. ; $30 \mathrm{~cm}$.

Dissertação (mestrado) - Universidade de Brasília, Faculdade de Planaltina, Programa de Pós-Graduação em Gestão Pública, 2015.

Inclui bibliografia.

Orientação: Andrea de Oliveira Gonçalves. 
PRISCILLA KETTILYN ROSA DE FRANÇA SOUSA

\section{A COMISSÃO DE ÉTICA COMO PRÁTICA EDUCATIVA: O CASO DA UNIVERSIDADE DE BRASÍLIA}

Dissertação apresentada ao Programa de PósGraduação em Gestão Pública para conclusão do Mestrado Profissional em Gestão Pública da Faculdade de Planaltina da Universidade de Brasília, como requisito para obtenção do título de Mestre em Gestão Pública. Aprovada em sua versão final pelos professores doutores abaixo assinados.

Aprovada em $/ 2015$

COMPOSIÇÃO DA BANCA EXAMINADORA

Professora Doutora Andréa de Oliveira Gonçalves - Orientadora Programa de Pós-Graduação em Gestão Pública - Universidade de Brasília

Professora Doutora Annita Valléria Calmon Mendes - Membro Interno Programa de Pós-Graduação em Gestão Pública - Universidade de Brasília

Professor Doutor César Augusto Tibúrcio Silva - Membro Externo Programa de Pós-Graduação em Ciências Contábeis - Universidade de Brasília

Professor Doutor Jonilto Costa Sousa - Membro Interno (suplente) Programa de Pós-Graduação em Gestão Pública - Universidade de Brasília 
Dedico este trabalho a Deus, para que seja um instrumento de sua providência aos homens. 


\section{AGRADECIMENTOS}

Em primeiro lugar, a Deus por ter me sustentando durante esse árduo percurso, por ter me inspirado a escrever sobre o tema desse estudo e por ter me capacitado a chegar até aqui.

À UnB, através do Programa de Pós-Graduação em Gestão Pública - PPGP, representado pela Coordenadora e Professora Doutora Andrea de Oliveira Gonçalves, pela oportunidade que representou para mim a abertura de incontáveis oportunidades de acesso ao conhecimento.

Ao Professor Doutor Emérito Elioenai Dornelles Alvez (in memoriam), por ter me apoiado no início deste estudo, como meu orientador e sobretudo amigo, depositando em mim sua confiança, que possibilitou despertar o meu potencial.

À Professora Doutora Annita Valléria Calmon Mendes, por ter contribuído significativamente para a minha pesquisa com suas sugestões fundamentais, e ao Mestre Edimilson Antônio de Oliveira por franquear seu tempo e conhecimento de modo a possibilitar o meu desenvolvimento na construção dessa dissertação.

Aos meus amigos mestrandos, Aristides Alvares Dourado Junior, Lussara Ribeiro Vieira Marques e Pedro Vieira da Silva, pela amizade e apoio em todos os momentos dessa caminhada.

À minha amiga do Gabinete do Reitor - UnB, Vera Regina Ferreira Telles, pelo apoio fundamental à realização desse sonho.

À minha mãe, Tânia Maria Rosa, por transferir a mim um pouco de sua garra e coragem, para que eu superasse todas as adversidades da vida e chegasse até aqui.

Às minhas irmãs, Stephane Michelle Rosa de França e Anna Beatriz Rosa de Sousa Silva, pelo carinho e incentivo.

Ao meu marido, Marcus Vinicius de Sousa França, por respeitar a minha dedicação ao longo dessa pesquisa. 
Mas o fruto do Espírito é amor, alegria, paz, paciência, amabilidade, bondade, fidelidade, mansidão e domínio próprio. Contra essas coisas não há lei.

Gálatas 5:22,23 


\section{RESUMO}

A ética se apresenta como importante instrumento, senão o mais importante, capaz de influenciar e promover um melhor ambiente laboral e das relações interpessoais e que, assim sendo, necessariamente irá passar pela cultura organizacional da instituição. Pesquisar sobre a importância de uma gestão ética, bem como mecanismos que auxiliem à sua implementação, favorece a aplicação de trabalhos que contribuam para uma gestão democrática. Este estudo de caso, portanto, envolve a Universidade de Brasília e sua Comissão de Ética. Trata de um estudo que objetiva avaliar a Comissão de Ética como prática educativa para o exercício da gestão ética e democrática na comunidade universitária da UnB. Foi realizado um estudo de caso de natureza qualitativa, exploratória e descritiva. Os dados foram coletados por meio de entrevistas e documentos. A análise dos dados utilizou os princípios da análise de conteúdo (Bardin, 1977). Os resultados, provenientes de categorias ex post, apontaram para uma necessária mudança de concepção da própria Comissão de Ética da UnB, partindo para a criação de um modelo aplicável à sua realidade, retratando que a organização deve priorizar as relações humanas que ocorrem no contexto da Universidade de Brasília e assim promover um ambiente ético e continuado, posto que a função educativa não tenha alcançado o devido desenvolvimento para a educação ética dos servidores da universidade. Constatou-se, ainda, que os normativos das Comissões de Ética ressaltam mais o processo de apuração ética, dando maior visibilidade à função punitiva, entretanto os resultados apontaram para uma maior conscientização ética nacional advinda de leis, órgãos de controle, bem como do próprio Sistema de Gestão da Ética, no qual a Comissão de Ética da UnB esta inserida.

Palavras-chave: Comissão de Ética; Universidade de Brasília; Ética; práticas educativas; resultado. 


\section{ABSTRACT}

Ethic is shown as an important instrument, capable of influence and promote a better working environment, and contribute with improving interpersonal relations, acting, therefore, straight on the organizational culture of the institution. To search about the importance of an ethical management, as well as of mechanisms that assist the implementation of that management, favour the application of studies that contribute with a democratic management. In this research, the University of Brasilia and its ethic committee were taken as object of study. It consists of a study that aims to evaluate the ethic committee as an educative practice for the exercise of an ethic and democratic management at UnB`s university community. In in, it was made a qualitative, exploratory and descriptive case study, which data was collected through interviews and documents. The analysing data was based in the perspective of Bardin content analysis (BARDIN, 1977). The results, obtained from ex post categories, pointed to a necessary change of conception of the UnB's Ethics Commission itself, which starts from the creation of a model that could be applied to their reality, depicting that the organization should prioritize the human relationships that occur in the context of the University of Brasilia, and, thus, promote an ethical and continued environment since the educational function has not achieved the expected development of ethical education of university workers. It was also found that the regulations of the Ethics Committees emphasize more the ethical determination process, prioritizing more the punitive function, rather than, as the results indicate, highlight a greater national ethical awareness arising from laws, regulatory agencies, as the Ethical Management System itself, in which the UnB's Ethics Committee is inserted.

Key words: Ethics Committee; University of Brasilia; Ethics; educational practices; result. 
LISTA DE FIGURAS

Figura 1. Página inicial do Site da Comissão de Ética/ UnB . 


\section{LISTA DE QUADROS}

Quadro 1. Comparação entre a pesquisa de ensino pedagógico tradicional e andragógico .....73

Quadro 2. Modelo de Gestão da Ética: três pilares e duas camadas 78

Quadro 3. Classificação dos Instrumentos de Gestão da Ética - Nível Fundamental e

Complementar 78

Quadro 4. Perfil dos 23 entrevistados .98

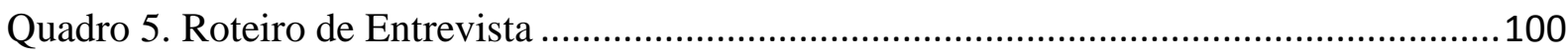

Quadro 6. Modelo Analítico da Pesquisa .............................................................................111

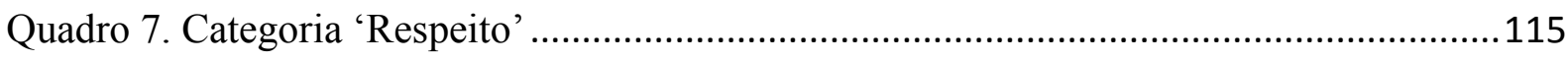

Quadro 8. Categoria ‘Boa Comunicação' ...........................................................................117

Quadro 9. Categoria 'Comportamento Adequado' ...........................................................119

Quadro 10. Categoria 'Compromisso com a instituição' ....................................................120

Quadro 11. Categoria 'Responsabilidade' .......................................................................121

Quadro 12. Categoria 'Parâmetros de Boa Convivência' .....................................................123

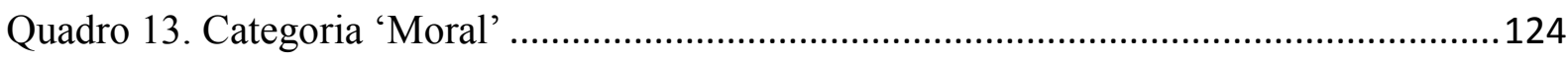

Quadro 14. Categoria 'Tolerância' .................................................................................... 126

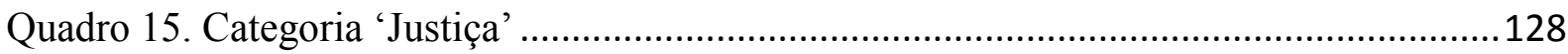

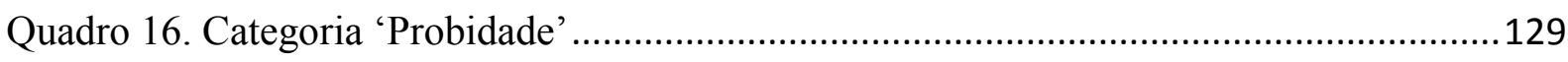

Quadro 17. Quadro Geral da Primeira Subdimensão ........................................................... 130

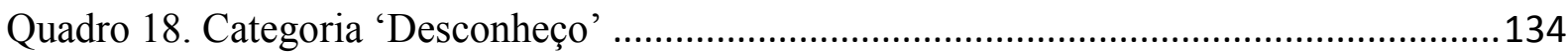

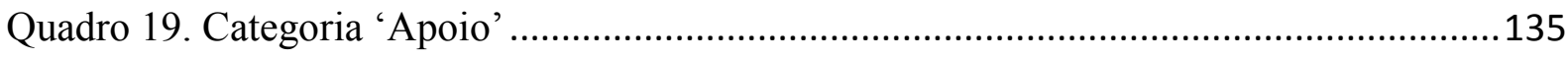

Quadro 20. Categoria 'Concordo Parcialmente' ...............................................................137

Quadro 21. Categoria 'Ampliação dos Programas' ............................................................. 138

Quadro 22. Categoria 'Apoio de Fachada' .......................................................................139

Quadro 23. Quadro Geral da Segunda Subdimensão - Questão 2 .......................................141

Quadro 24. Categoria 'Divulgar o Trabalho da Comissão de Ética' .....................................145

Quadro 255. Categoria 'Investimento da Administração Superior' - Questão 3 ...................147

Quadro 26. Categoria 'Palestras' - Questão 3..................................................................148 


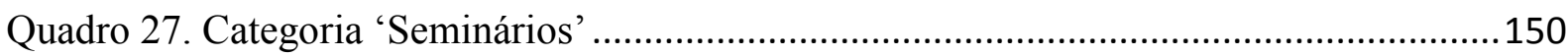

Quadro 28. Quadro Geral da Segunda Subdimensão - Questão 3 .......................................151

Quadro 29. Categoria 'Resistência das Pessoas' - Questão 4 .............................................154

Quadro 30. Categoria 'Falta de Apoio da Administração Superior' - Questão 4 ..................156

Quadro 31. Categoria ‘Obstáculos a Serem Vencidos' - Questão 4 .....................................157

Quadro 32. Quadro Geral da Segunda Subdimensão - Questão 4 .......................................158

Quadro 33. Categoria 'Equipe' - Facilitadores .................................................................162

Quadro 34. Categoria ‘Canais de Comunicação’ - Facilitadores..........................................164

Quadro 35. Categoria 'Divulgação' - Facilitadores ........................................................... 165

Quadro 36. Categoria ‘Ambiente Acadêmico' - Facilitadores ...........................................166

Quadro 37. Categoria 'Legislação' - Facilitadores ............................................................167

Quadro 38. Categoria 'Mediação' - Facilitadores.............................................................169

Quadro 39. Categoria 'Reconhecimento' - Facilitadores .................................................171

Quadro 40. Categoria 'Implementação' - Facilitadores .................................................... 172

Quadro 41. Quadro Geral da terceira Subdimensão (Questão 5 - Facilitadores)...................173

Quadro 42. Categoria 'Falta de Apoio da Administração Superior' - Dificultadores .......176

Quadro 43. Categoria 'Espaço Físico’ - Dificultadores .....................................................177

Quadro 44. Categoria 'Servidores da UnB - Dificultadores ................................................179

Quadro 45. Categoria ‘Marco Regulatório Frágil' - Dificultadores ....................................181

Quadro 46. Categoria 'Dificuldades do Trabalho em Equipe' - Dificultadores ....................182

Quadro 47. Quadro Geral da terceira Subdimensão (Questão 5 - Dificultadores) .................183 


\section{LISTA DE SIGLAS E ABREVIATURAS}

ACPP: Acordo de Conduta Pessoal e Profissional

BDTD: Biblioteca Digital Brasileira de Teses e Dissertações

CPF: Cadastro de Pessoas Físicas

CEP/PR : Comissão de Ética da Presidência da República

CE-UnB: Comissão de Ética da Universidade de Brasília

CEP: Comissão de Ética Pública

OEA: Convenção Interamericana Contra a Corrupção da Organização dos Estados Americanos

CAPES: Coordenação de Aperfeiçoamento de Pessoal de Nível Superior

CPAD: Coordenação de Processo Administrativo Disciplinar

PROCAP: Coordenadoria de Capacitação e Educação

PROCAP/DGP: Coordenadoria de Capacitação e Educação do Decanato de Gestão de Pessoas

DGP: Decanato de Gestão de Pessoas

ENAP: Escola Nacional de Administração Pública

GRE: Gabinete do Reitor

IBGE: Instituto Brasileiro de Geografia e Estatística

IBICT: Instituto Brasileiro de Informação em Ciência e Tecnologia 
NPM: New Public Management

ONU: Organização das Nações Unidas

OCDE: Organização para a Cooperação e o Desenvolvimento Econômico

RSP: Revista do Serviço Público

SIC: Serviço de Informação ao Cidadão

TCLE: Termo de Consentimento Livre e Esclarecido

UnB: Universidade de Brasília 


\section{SUMÁRIO}

1 INTRODUÇÃO

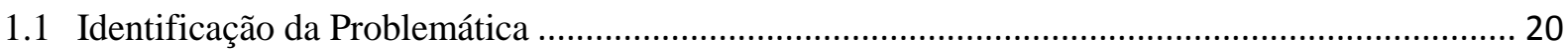

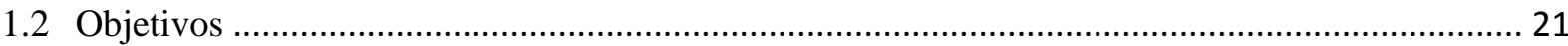

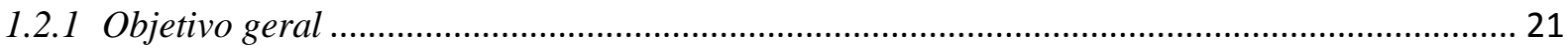

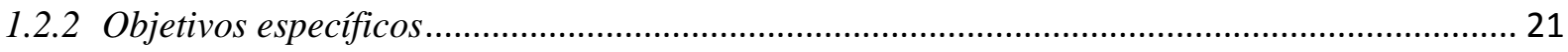

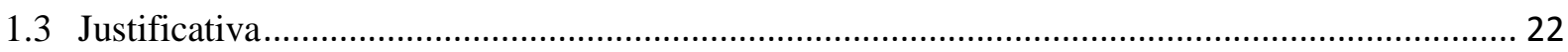

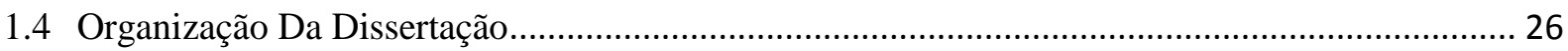

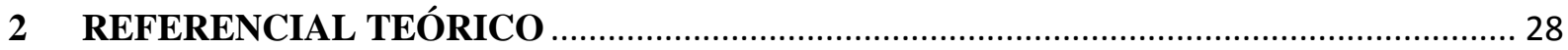

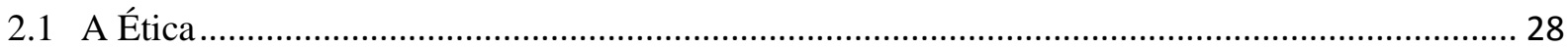

2.2 Gestão Pública e a Introdução da Atividade Administrativa Ética no Ordenamento Administrativo Brasileiro

2.3 A Nova Gestão Pública: Criação de Comissões de Ética no Contexto da Descentralização da Gestão Intergovernamental

2.4 Gestão da Ética como Pratica que Favorece a Gestão Democrática

2.5 Eficiência, Eficácia: Correlação Necessária, como Um dos Fatores, para a Implementação da

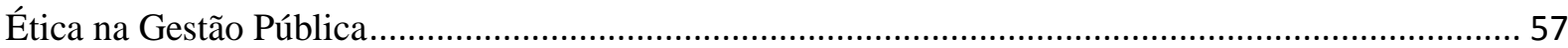

2.6 O Processo Decisório nas Organizações e a Sua Dimensão Ética.................................................... 63

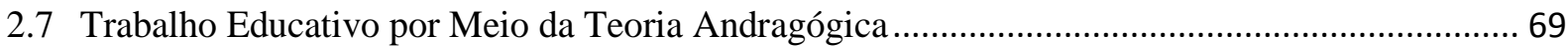

2.8 Instrumentos de Gestão da Ética como Proposta de Práticas Educativas ....................................... 80

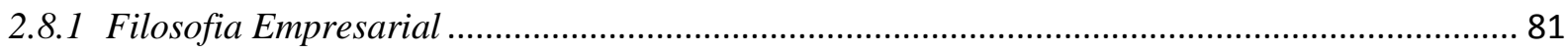

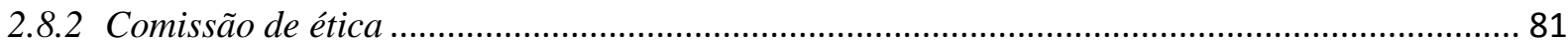

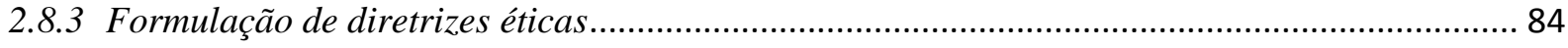

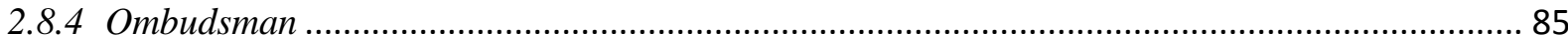

2.8.5 Auditorias éticas- avaliações periódicas sobre condutas empresariais ................................... 88

2.8.6 Promoções Educacionais - Aproximação da Empresa com seus Públicos - internos e externos88 


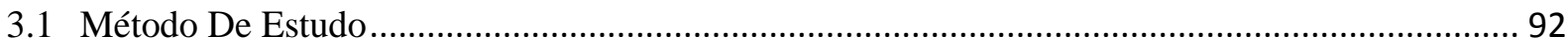

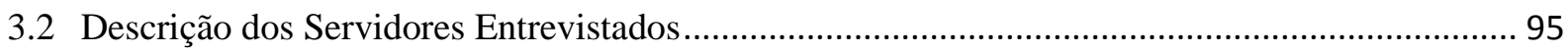

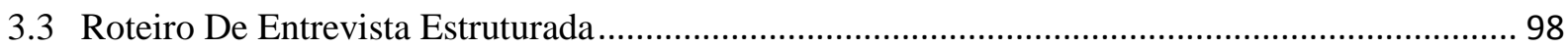

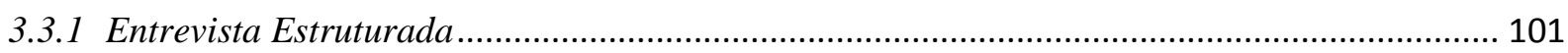

3.3.2 Apresentação da Comissão de Ética na UnB Segundo os Normativos e como Está Estruturada

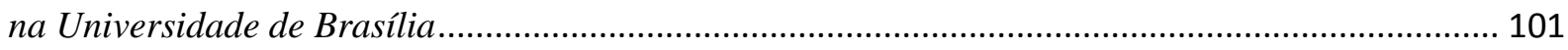

3.4 A Construção das Dimensões da Pesquisa ......................................................................... 104

3.5 Estratégia Utilizada Para O Exame Dos Dados ................................................................. 107

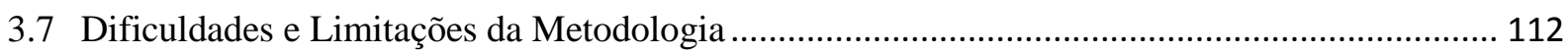

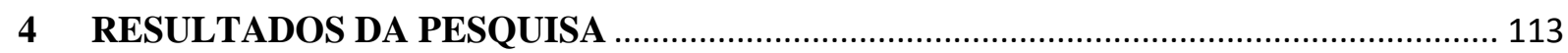

4.1 Apresentação das Dimensões e suas Categorias........................................................................... 113

4.1.1 Primeira Subdimensão: Ética no Ambiente Laboral …........................................................... 114

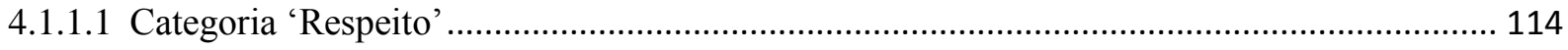

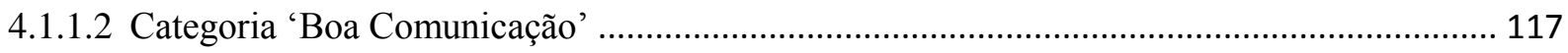

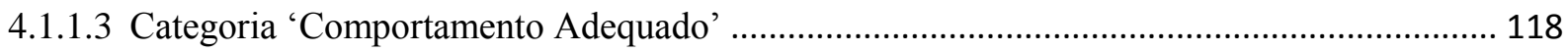

4.1.1.4 Categoria 'Compromisso com a Instituição' ......................................................................... 120

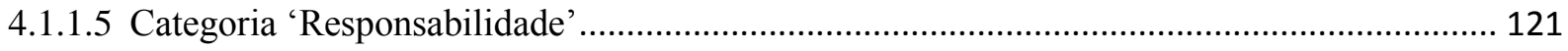

4.1.1.6 Categoria 'Parâmetros de Boa Convivência' ............................................................................ 122

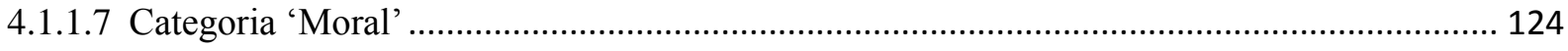

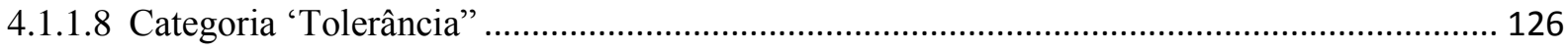

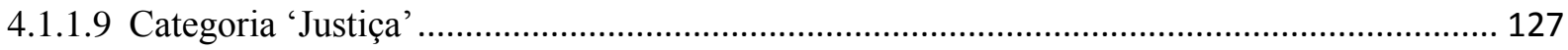

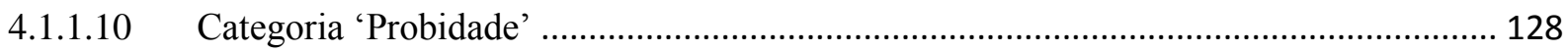

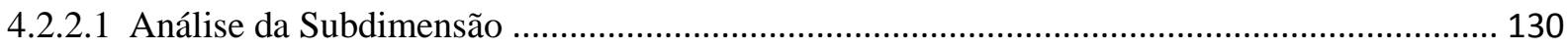


4.2.3 Segunda Subdimensão: Práticas Educativas e Instrumentos de Gestão da Ética na Universidade

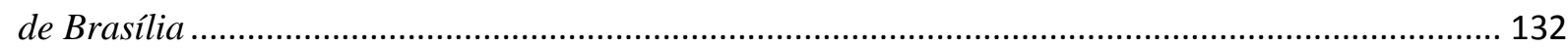

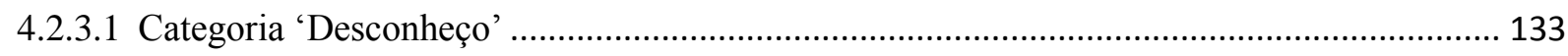

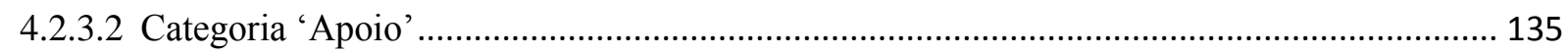

4.2.3.4 Categoria ‘Ampliação dos Programas' .............................................................................. 138

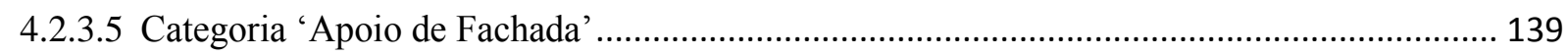

4.2.3.6 Categoria ‘Divulgar o Trabalho da Comissão de Ética - Questão 3 ..................................... 145

4.2.3.7 Categoria 'Investimento da Administração Superior' - Questão 3 ....................................... 147

4.2.3.8 Categoria ‘Palestras' - Questão 3 ............................................................................... 148

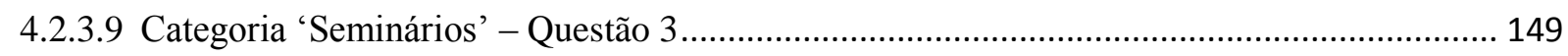

4.2.3.10 Categoria 'Resistência das Pessoas' - Questão 4 ........................................................... 154

4.2.3.11 Categoria 'Falta de Apoio da Administração Superior' - Questão 4 ............................... 155

4.2.3.12 Categoria ‘Obstáculos a Serem Vencidos’ - Questão 4 ................................................ 157

4.2.4 Terceira Subdimensão: Gestão da Ética em Relações de Trabalho ......................................... 161

4.2.4.1 Categoria ‘Equipe' - Facilitadores............................................................................... 162

4.2.4.2 Categoria ‘Canais de Comunicação' - Facilitadores ........................................................... 164

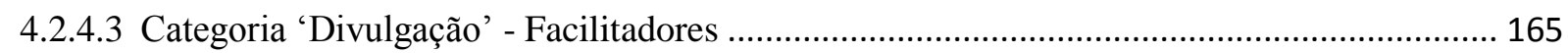

4.2.4.4 Categoria ‘Ambiente Acadêmico' - Facilitadores ................................................................... 166

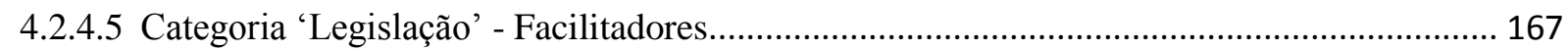

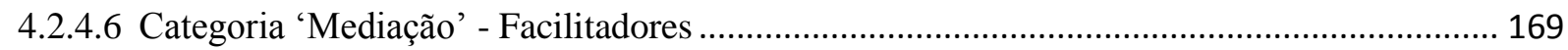

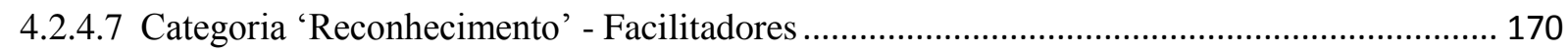

4.2.4.8 Categoria 'Implementação' - Facilitadores ........................................................................ 172

4.2.4.9 Categoria 'Falta de Apoio da Administração Superior' - Dificultadores ................................ 176

4.2.4.10 Categoria ‘Espaço Físico' - Dificultadores ....................................................................... 177

4.2.4.11 Categoria ‘Servidores da UnB - Dificultadores...................................................... 179

4.2.4.12 Categoria ‘Marco Regulatório Frágil - Dificultadores .................................................... 180

4.2.4.13 Categoria 'Dificuldades do Trabalho em Equipe'- Dificultadores.................................. 182 


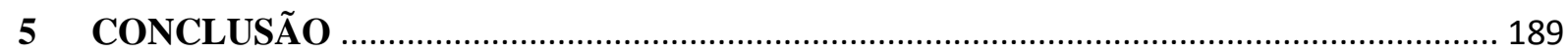

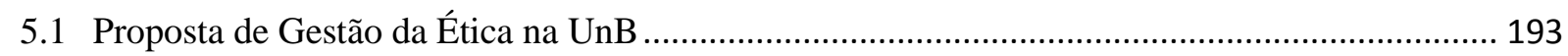

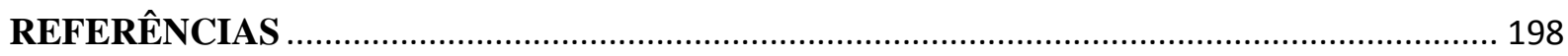

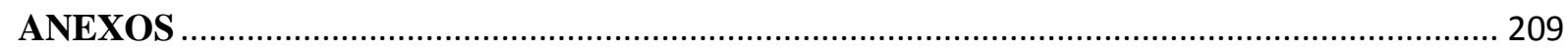

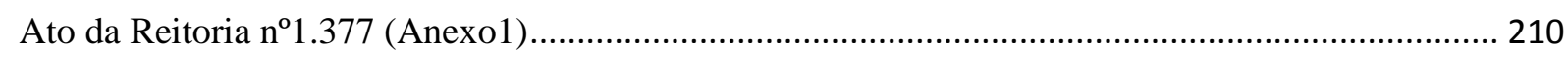

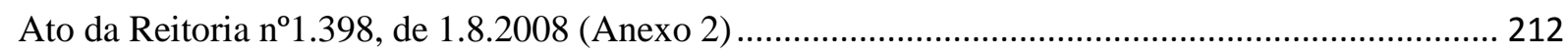

Regimento Interno da Comissão de Ética da UnB (Anexo 3), de 13.11.2008 ……........................... 213

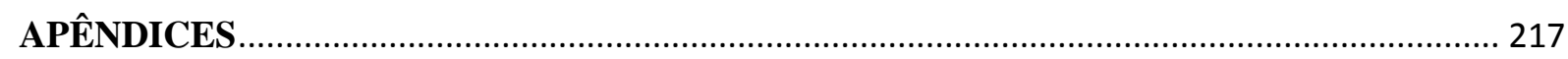

Apêndice A -Roteiro De Entrevista Estruturada …...................................................................... 218

Apêndice B - Termo De Consentimento Livre E Esclarecido ........................................................ 220 


\section{INTRODUÇÃO}

No contexto atual, em que os problemas de desvios éticos, cada vez mais, influenciam o ambiente laboral, causando o adoecimento das relações interpessoais, verificase a necessidade de se buscar medidas alternativas para a melhoria desses relacionamentos, os quais influenciam a cultura organizacional. Pesquisar sobre a importância de uma gestão ética, bem como sobre os mecanismos que auxiliem à sua implementação, favorece à aplicação de trabalhos que contribuam para uma gestão democrática.

O presente estudo revela a importância do trabalho em analisar perspectivas de formação para a ética em âmbito institucional, uma vez que através da pesquisa aqui realizada foram levantados instrumentos de gestão da ética e princípios da teoria andragógica, a qual prescreve como deve ocorrer a educação do público adulto.

O descontentamento com condutas antiéticas não é uma questão pontual de relacionamentos interpessoais, mas afeta as gestões das organizações tanto no Brasil, quanto no mundo, suscitando a tomada de decisões em âmbito internacional para a adoção de medidas que favoreçam a gestão ética.

Nesse sentido, a questão 'ética' se mostrou latente, de modo a viabilizar o estabelecimento de um clima organizacional favorável a melhores tomadas de decisões para a instituição.

A ética deve estar arraigada às atitudes cotidianas de todos os servidores públicos, conforme reza o Capítulo I, Seção I, Das Regras Deontológicas do Código de Ética Profissional do Servidor Público Civil do Poder Executivo Federal, que afirma:

I- $\quad$ A dignidade, o decoro, o zelo, a eficácia e a consciência dos princípios morais são primados maiores que devem nortear o servidor público, seja no exercício do cargo ou função, ou fora dele, já que refletirá o exercício da vocação do próprio poder estatal. Seus atos, comportamentos e atitudes serão direcionados para a preservação da honra e da tradição dos serviços públicos. 
II- $\quad$ o servidor público não poderá jamais desprezar o elemento ético de sua conduta. Assim, não terá que decidir somente entre o legal e ilegal, o justo e o injusto, o conveniente e o inconveniente, o oportuno e o inoportuno, mas principalmente entre o honesto e o desonesto, consoante às regras contidas no art.37, caput, e $\$ 4^{\circ}$, da Constituição Federal (BRASIL, 1994).

A gestão ética é como peça fundamental para o estabelecimento da ordem nas organizações, no sentido de moralizar os trabalhos e as instituições, e de atender com eficiência aos anseios do público, haja vista ser essa a sua finalidade.

Nesta dissertação, enfatiza-se o estudo da comissão de ética, em uma proposta de trabalho que poderá ser desenvolvida de modo contínuo dentro da Universidade de Brasília. Nela, busca-se o desenvolvimento de uma análise que aborde mecanismos para a disseminação da gestão da ética, de modo a prevenir conflitos em relacionamentos no ambiente de trabalho, e portanto, contribuir para o sucesso das organizações, em especial da UnB.

Matos (2008) relata que quando não há uma cultura ética, em que as pessoas são indiferentes às questões morais, tudo passa a ser permitido, e o lucro norteia todas as ações de modo a subjugar todos os valores. A competição que ocorre provoca comportamentos predatórios, em que todos os valores e concorrentes são subjugados e eliminados, respectivamente.

Problemas relacionais influenciam significativamente no processo decisório das organizações, bem como no estabelecimento da gestão ética e democrática. E quando se fala de adoecimento de relações, refere-se à fala de Passos (2010), em que atualmente verifica-se um verdadeiro culto ao poder e prazer, o que tem provocado o isolamento, a depressão e a falta de perspectiva para o futuro, haja vista o desenvolvimento de um hedonismo que, de longe, leva essas pessoas ao bem-estar.

Outro fator é o poder econômico em que o ser humano está totalmente voltado para a busca do lucro. Desse modo, a sociedade capitalista dividiu a população em classes adversas, em que uma colhe os frutos do poder e a outra sofre com os efeitos desse poder, e embora os integrantes dessa sociedade desejem o bem-estar material, somente alguns desfrutarem dele.

E é nessa disputa pelo bem-estar material que é gerado grande parte dos conflitos, ocasionados por condutas egoístas e hipócritas, em que os fins justificam os meios para se alcançar o poder, mesmo que ocorra em detrimento de outras pessoas. O respeito e a partilha são abnegados em busca de objetivos pessoais, haja vista que, se a meta é a autovalorização, 
para que então se preocupar como o próximo? E assim, ocorre a deterioração das relações em sociedade.

A respeito da necessidade de se criar cultura ética organizacional, Passos (2010) coloca a importância de trabalhar a formação ética em organizações, pois segundo a autora, a criação dessa cultura auxilia no enfrentamento de problemas, de modo a resolvê-los, evitando, assim, que outros problemas ocorram. Afirma ainda que orienta o caminho a ser percorrido, limitando o espírito impetuoso, além de incentivar a crítica e as práticas responsáveis e coerentes. Logo, é imperativo que tal prática seja recorrente e esteja aliada ao compromisso de todos os integrantes da organização.

Desse modo, é necessário que haja a prática constante da ética, que deve ser reconhecida pelos dirigentes da organização, bem como implementada, cabendo aos dirigentes máximos dar o exemplo, comportando-se de modo adequado, com vistas a estimular as condutas éticas, e favorecer a promoção e implementação de um clima ético na instituição.

Aguilar (1996) recomenda que o custo da conduta antiética pode ir muito além das penalidades legalísticas, notas desfavoráveis na imprensa e prejuízo nas relações com a clientela e de ordem financeira. Comumente, a implicação mais danosa é o dilaceramento do clima organizacional.

Para que haja a efetivação da Ética, Soares (2014) argumenta ser necessária a adoção de metodologias e instrumentos com condução e acompanhamento que promoverão a participação das pessoas, gerando por esse caminho, uma cidadania que seja ativa. $\mathrm{O}$ progresso da eficácia da administração pública ocorre com a indução pela qualidade ética das tomadas de decisões.

Assim sendo, o presente estudo visa sugerir ações, por meio de instrumentos de Gestão da Ética, articulada ao método da Andragogia, que objetiva a educação de adultos. No 
caso proposto, revela-se como educação para a ética institucional, uma vez que será implementada com os instrumentos de Gestão da Ética levantados nesse estudo, e, assim, ratificar a ideia de que a constituição de uma comissão de ética pode contribuir como prática educativa para o exercício da Gestão da Ética e, dessa forma, responder positivamente a questão da pesquisa.

O presente estudo buscou acrescentar ao referencial teórico estudado medidas alternativas que funcionam como práticas educativas para a gestão da ética na UnB, identificando propostas por meio do estudo de caso aqui realizado, para um projeto educacional que possa ser desenvolvido pela Comissão de Ética da Universidade de Brasília.

As pessoas são diferentes e, portanto, estas diferenças contribuem para a formação de conflitos, uma vez que os indivíduos tiveram uma determinada educação familiar e vivenciaram experiências diferentes de vida. Por isso, é necessário buscar medidas que ajudem a prevenir os conflitos e guie as pessoas para uma cultura ética. Neste sentido, em concordância com Passos (2010), o desejo é o de se encontrar uma nova ordem moral, em que não haja injustiças, em que o tratamento entre as pessoas seja mais humano, respeitoso, urbano e digno, na ideia de não prejudicar a ninguém, de respeitar o espaço e os seus limites e os do próximo, de seguir, dentro do possível, o máximo dessa linha reta invisível que são as ações humanas, de agir no sentido de criar as condições para com que esta 'nova' ordem moral seja realidade. Se houver permanência na inércia, na passividade, nada irá mudar ou acontecer.

A pesquisa apresentada considera o tema de fundamental importância para a configuração da ética no âmbito da Administração Pública Federal. A promoção de atividades andragógicas constitui a essência de todo o programa de promoção da ética, e necessita de articulação teórico-metodológica. Por isso, foram estudados os princípios da teoria 
andragógica nessa dissertação, de modo que o levantamento dos instrumentos de gestão da ética, aqui realizado, pudesse efetivar essa política de educação para a ética institucional.

Nesse sentido, a pesquisa propõe uma análise por meio de estudo de caso. Nele, buscase implementar os instrumentos de gestão da ética como prática educativa e com o respaldo teórico-metodológico da Andragogia, que apresenta técnicas de aprendizagem interativas para o público adulto, e, assim, iniciar um trabalho educacional, através da Comissão de Ética da UnB.

Assim, e considerando-se o baixo número de publicações acadêmicas deste assunto, justifica-se a temática abordada nesse trabalho. Diante desta constatação, e atendendo às reflexões de Amorim (2000),

1. que a Comissão de Ética trata de um ente que deve promover a reflexão sobre os valores e padrões de conduta no âmbito das instituições;

2. que a Comissão de Ética fomenta a reflexão sobre as bases para uma nova ética na esfera pública, sustentada em valores orientadores das relações entre o Estado e a Sociedade, a equidade, a justiça, a liberdade e a accountability;

3. é a Comissão de Ética que apresenta instrumentos normativos e disciplinadores da questão ética no trato da 'coisa pública'.

\subsection{Identificação da Problemática}

A problemática desse estudo se manifesta por meio da seguinte questão: a constituição de uma Comissão de Ética contribui como prática educativa para o exercício da gestão ética e democrática na comunidade universitária da Universidade de Brasília? 


\subsection{Objetivos}

\subsubsection{Objetivo geral}

Avaliar a Comissão de Ética como prática educativa para o exercício da gestão ética e democrática na comunidade universitária da UnB.

\subsubsection{Objetivos específicos}

Do objetivo geral desdobram-se os objetivos específicos, que seguem uma lógica que perfazem a análise dos dados colhidos para identificação dos resultados apresentados. Os objetivos específicos não são colocados de forma aleatória, mas estão inseridos em uma sequência crescente em que primeiro se descreve; depois, investiga-se; a seguir, enuncia-se; e, e, por fim, recomenda-se. São eles:

a) descrever atribuições da Comissão de Ética, segundo os normativos, para a gestão ética da Universidade;

b) descrever a compreensão da dimensão ética nas relações de trabalho no âmbito da Comissão de Ética da Universidade de Brasília;

c) investigar os aspectos facilitadores e dificultadores do processo de trabalho educativo da Comissão de Ética da UnB;

d) enunciar as possibilidades de implantação de instrumentos de gestão da ética;

e) recomendar ações que contribuam para a educação ética na Universidade de Brasília. 


\subsection{Justificativa}

A justificativa desta pesquisa sobre práticas educativas, por meio de instrumentos de Gestão da Ética, que possam contribuir para os trabalhos educativos da Comissão de Ética da UnB, revela-se em três contribuições: pessoal, social e científico.

A justificativa sob a percepção pessoal tem por relevância contribuir com propostas de práticas educativas que visem à conscientização ética dos servidores da UnB.

A justificativa sob a percepção social tem por relevância o sentido de que poderá servir como um manual orientador das comissões de ética na sociedade, apesar de ser um estudo de caso na UnB, haja visto o levantamento de propostas aliadas aos instrumentos de Gestão da Ética e da teoria Andragógica, as quais oferecem respaldo teórico para subsidiar os planos de trabalho destas comissões. Soma-se a isto, a possibilidade de que, caso essas propostas aqui levantadas sejam implementadas, a instituição poderá ser beneficiada com menos processos administrativos disciplinares, que são bastante onerosos para a instituição, além de outros benefícios, relatados no decorrer deste estudo, e que serão provenientes de uma efetiva gestão ética e educativa.

Quanto à relevância para a Ciência, esta se dá no atual contexto em que são poucas as produções acadêmicas sobre o tema desta dissertação, conforme o estudo bibliométrico realizado, em que foram feitas buscas, em âmbito nacional, nos seguintes bancos de dados de teses e dissertações:

- $\quad$ Coordenação de Aperfeiçoamento de Pessoal de Nível Superior (Capes) “que coloca à disposição da comunidade acadêmica o Banco de Teses, na qual será possível 
consultar todos os trabalhos defendidos na pós-graduação brasileira ano a ano" (CAPES, 2011);

- $\quad$ Biblioteca Digital Brasileira de Teses e Dissertações (BDTD) que "tem por objetivo reunir, em um só portal de busca, as teses e dissertações defendidas em todo o país e por brasileiros no exterior" (BDTD, IBICT, 2015);

- $\quad$ BDTD, concebida e mantida pelo Instituto Brasileiro de Informação em Ciência e Tecnologia (IBICT), e como o presente trabalho está situado no âmbito da Administração Pública, Escola Nacional de Administração Pública - ENAP (ENAP, 2015); e,

- Universidade de Brasília, no Repositório Institucional de Teses e Dissertações da UnB (UNB, 2015 (c)).

A busca nos bancos de dados citados foram realizadas observando um intervalo de cinco anos, de 2010 até 2015; por título, haja vista o que revela Lakatos e Marconi (2003) quando relatam que o título de um estudo não corresponde ao tema, nem a demarcação do tema, mas procede dos objetivos geral e específicos quase como uma 'síntese' dos próprios". Assim, a pesquisa nos bancos de dados aqui citados foi realizada preferencialmente pelos títulos de teses e dissertações, posto que em alguns casos não foram apresentados registros referentes à busca por títulos, o que acarretará a busca por todos os dados.

Os descritores utilizados para a realização de buscas foram a Gestão de Ética AND Educação, Educação Ética, Comissão de Ética, Comissão de Ética AND Educação Continuada, Educação Ética AND Administração Pública e Educação Ética AND Gestão Pública.

No Banco de Teses da Capes foram encontrados os seguintes resultados em títulos, na busca avançada, para "gestão de ética AND educação": nenhum registro. Ao colocar no campo de busca o título "educação ética", apareceu apenas um registro na área 
médica. Em seguida, ao pesquisar por “comissão de ética”, no título, a pesquisa mais uma vez retornou apenas um registro, também na área da saúde. A pesquisa por "Comissão de Ética AND educação continuada" não resultou em nenhuma tese pertinente aos descritores, em nenhuma área de conhecimento. Por "Educação ética AND Administração Pública", novamente não foi encontrada nenhuma tese pertinente aos descritores utilizados em nenhuma área de conhecimento. Por fim, ao se pesquisar por "educação ética AND Gestão Pública" verificou-se apenas um registro referente ao Mestrado Profissional em Teologia. Entretanto, na BDTD, ao pesquisar por títulos, a pesquisa retornou um registro, no campo da Administração, logo não há registro nas outras áreas de conhecimento em relação à "gestão de ética AND educação". De igual modo, ao digitar "educação ética”, também em títulos, foram localizados cento e dezoito registros, sendo que deste resultado, apenas dois se encontram na área da Administração.

Em seguida, de modo a manter a simetria, em relação aos termos buscados na pesquisa realizada no Banco de Dados da CAPES, buscou-se também pelo termo “comissão de ética", tendo como resultado os seguintes dados: um registro na área da Administração e um registro na área da saúde. Dando continuidade na pesquisa por outros descritores, dessa vez, buscou-se por "Comissão de Ética AND educação continuada", e nenhuma tese pertinente aos descritores foram encontrados em nenhuma área de conhecimento. Ao pesquisar por "Educação Ética AND Administração Pública" foi encontrado os seguintes resultados: um registro em Administração Pública, um registro em Informática na educação, um registro em Educação e, por fim, um registro em Teologia. No último descritor "Educação ética AND Gestão Pública" foi encontrado o seguinte resultado: um registro para Administração Pública, um registro para Teologia, um registro para Educação e, por fim, um registro para Informática na Educação. 
Quanto ao repositório digital da ENAP, ao listar os títulos das produções científicas por "gestão de ética AND educação" no período de 2010 até 2015, em que continha no assunto da pesquisa avançada a palavra 'ética', não foram localizados registros. Ao escrever "educação ética" com os mesmos critérios de pesquisa citados anteriormente, a busca novamente não apresentou resultados.

Ao digitar "comissão de ética” em Produção Cientifica: Teses e Dissertações, com o filtro de 2010 até 2015, não foi encontrado nenhum registro dentro do assunto deste trabalho. Seguindo com outros descritores, "Comissão de Ética AND educação continuada" de cento e trinta e nove resultados, foram encontrados somente 7 relacionados aos descritores nos títulos. Ao se pesquisar por "educação ética AND Administração Pública” de 80 resultados, foram encontrados somente sete relacionados aos descritores em títulos. Por fim, ao se pesquisar "educação ética AND Gestão Pública”, dos noventa e quatro resultados, foram encontrados novamente sete registros relacionados os descritores.

Na pesquisa realizada no Repositório Institucional de Teses e Dissertações da UnB, pelos mesmos descritores utilizados nos bancos de dados anteriores, verificaram-se os seguintes resultados: "gestão de ética", de noventa e quatro resultados, somente dois eram relacionados. Quanto ao título "educação ética", de quinhentos e noventa resultados, apenas nove eram relacionados. Já na busca sobre "Comissão de Ética”, dos vinte resultados, nenhum registro era relacionado. Buscando-se por "Comissão de Ética AND educação continuada", dos quinze resultados, nenhum registro era relacionado. Quanto à "educação ética AND Administração Pública", dos quatrocentos e trinta e sete resultados, somente quatro eram relacionados. Por fim, sobre o título "educação ética AND Gestão Pública”, dos setenta e oito resultados, só foram encontrados dois registros relacionados.

Assim, a temática deste trabalho se justifica uma vez que existem poucas publicações acadêmicas sobre o assunto no âmbito da Administração, além da importância da 
instituição das comissões de ética em órgãos públicos, como também de um trabalho educativo que vise ao desenvolvimento de condutas éticas, que, por sua vez, contribuirão para a saúde nas relações interpessoais. Justifica-se, por fim, por ser um trabalho que contribui para a função educativa, na medida em que esta seja essencial para a superação do papel coercitivo das comissões.

\subsection{Organização da Dissertação}

Para alcançar os objetivos propostos, a Dissertação está estruturada em cinco partes.

O primeiro capítulo é a Introdução, em que se relata a importância de estudar a dimensão da ética nas relações de trabalho, perfazendo tal, pela necessidade de se buscar medidas alternativas que possam ser executadas pela Comissão de Ética/UnB, para a melhoria dos relacionamentos interpessoais no ambiente laboral. Nela, realizou-se a justificativa, sob a ordem pessoal, social e científica dessa pesquisa, bem como a identificação do problema, objetivos geral e específicos. Espera-se neste estudo contribuir para uma gestão ética e democrática.

No segundo capítulo encontra-se o Referencial Teórico, apresentado sob os seguintes subitens: Ética; Gestão Pública e a Introdução da Atividade Administrativa ética no ordenamento administrativo brasileiro; A Nova Gestão Pública: criação de comissões de ética no contexto da descentralização da gestão intergovernamental; Gestão da Ética como Prática que Favorece a Gestão Democrática; Eficiência, eficácia: correlação necessária como um dos fatores para a implementação da ética na gestão pública; O Processo Decisório nas Organizações e a sua Dimensão Ética: trabalho educativo por meio da teoria Andragógica. 
Esses assuntos foram abordados por orientarem a análise, compreensão e implementação do presente estudo.

No terceiro capítulo, trabalhou-se o percurso metodológico, bem como os métodos de estudo, revelando tratar-se de uma pesquisa empírica com abordagem de um estudo de caso com aplicação prática e dirigida à solução de problemas. Realizou-se também, sob a metodologia aplicada, uma pesquisa bibliográfica em relação às produções acadêmicas referentes a teses e dissertações relacionadas ao título deste estudo, o qual encontra-se presente no item justificativa desse trabalho. Para o referencial teórico e interpretação dos dados realizou-se um estudo por meio de pesquisa bibliográfica e documental, assim como outros que serão detalhados no decorrer da pesquisa. Nesse mesmo capítulo, foram revelados a descrição dos servidores entrevistados, bem como: o roteiro de entrevista estruturada; a entrevista estruturada; a análise e interpretação dos dados e a estratégia utilizada para o exame dos dados referentes à caracterização pessoal dos entrevistados; e as dificuldades e limitações em termos metodológicos da pesquisa.

No quarto capítulo, apresentaram-se os resultados da pesquisa: instrumentos de gestão da ética como proposta de práticas educativas, bem como a análise de conteúdo, através da apresentação das dimensões e suas categorias, que foram levantadas na entrevista estruturada realizada com vinte e três servidores da UnB. Nesse mesmo capítulo, apresentouse a conclusão da análise dos dados levantados na análise de conteúdo. Por fim, no quinto e último capítulo são expostos a conclusão e as sugestões para futuros estudos, além de proposta para a gestão da ética na UnB. 


\section{REFERENCIAL TEÓRICO}

A escolha pelos temas que compõem o Referencial Teórico desta dissertação se fundamenta em ideias que foram desenvolvidas nas disciplinas cursadas no curso de PósGraduação em Gestão Pública. Essas ideias foram acrescidas, de modo a atingir o objetivo geral, proposto pela pesquisa.

O arcabouço teórico apresentado buscou auxiliar no entendimento da questão abordada nesta dissertação, e em compreender as dimensões e categorias elencadas, a partir do tratamento dos dados. Ressalta-se que a literatura levantada poderá, inclusive, ser utilizada como respaldo teórico para ações que contribuam para a educação ética na Universidade de Brasília. Este capítulo objetiva, então, caracterizar os conceitos de ética à luz de alguns filósofos - Sófocles (2005) e Platão (2014) -, bem como das teorias deontologistas e utilitaristas, e de outros autores, tais como Farias (2013), Passos (2010) Caluri (2011) e uma entrevista feita por Jô Soares a Mário Sérgio Cortella (op.cit.)

Estes conceitos foram relevantes para a obtenção de respostas ao problema delimitado, uma vez que analisar a Comissão de Ética da Universidade de Brasília e a compreensão da dimensão como prática educativa impôs uma análise cuidadosa na investigação.

\subsection{A Ética}

A Ética é uma ciência estudada pela Filosofia e há muito tempo vem sendo analisada por vários estudiosos, com o objetivo de melhorar a interação social entre as pessoas. As normas éticas norteiam o bom relacionamento com o próximo. A ética é uma 
questão de escolha, ou seja, não se nasce com ela, pode-se agir ou não eticamente. No entanto, todos os atos cometidos têm as suas implicações, e é por isso, que se torna necessário ficar atento às consequências causadas ao se tomar determinadas atitudes.

A ética é fundamentada por algumas teorias, tais como a Ética Deontológica. A palavra deontologia é originária do vocábulo deon, do grego, cuja tradução para a língua portuguesa é ‘obrigação’. A respeito dessa ética, Farias (2013:5) diz que “[...] uma ação será considerada correta se tiver como motivo princípios universais, auto evidentes, que independem das consequências. Exemplos destes princípios são: ser honesto, cumprir as promessas, não mentir."

Pode-se verificar, no campo da Filosofia, que a Ética Deontológica está embasada na tragédia de Antígona, escrita por Sófocles. Nela, Creonte adverte Antígona sobre o descumprimento de sua determinação e Antígona responde que as leis divinas são superiores à sua ordem e que sempre existiram, enfatizando que estas leis nunca foram escritas, mas são irrevogáveis (SÓLFOCLES, 2005 apud FARIAS, 2013).

Outro relato que fundamenta a ética deontológica é o Diálogo de Criton, escrito por Platão, em que Sócrates afirma não ser justo retribuir a injustiça com injustiça, pois o procedimento injusto é sempre inadmissível (PLATÃO, 2006 apud FARIAS, 2013). Farias (2003:8) interpreta o que Kant disse da seguinte forma: "Somente pode ser considerada ética a ação que puder ser universalizada." Diante do exposto, pode-se verificar que valores morais universalizados constituíram a ética deontológica.

As leis do Brasil, em especial o Decreto $\mathrm{n}^{\circ} 1.171 / 94$, do Código de Ética do Servidor Público Civil do Poder Executivo Federal, são influenciadas pela ética deontológica e também utilitarista. Verifica-se, no capitulo I, páginas iniciadas pelo título 'Das Regras Deontológicas', Seção II, Inciso XV, alínea $c$, a constatação desta influência: “ser probo, reto, leal e justo, demonstrando toda a integridade do seu caráter, escolhendo sempre, quando 
estiver diante de duas opções, a melhor e a mais vantajosa para o bem comum" (BRASIL, 1994). Quanto à concepção utilitarista a qual será detalhada mais à frente, no entanto, por hora, diz Passos:

\begin{abstract}
A Seção II do referido Código destina-se a explicitar os deveres do servidor público. Seu artigo XIV [...] enfatiza que o servidor precisa ser cortês, atencioso, cuidadoso e respeitoso com os usuários do serviço público. Também que é seu dever ser rápido, assíduo, reto, justo, leal e íntegro, escolhendo sempre a opção que for beneficiar o maior número de pessoas. Essa é, sem dúvida, uma orientação moral importante. [...] O código nos remete à concepção utilitarista que afirma que o bom é o útil ou vantajoso para o maior número de pessoas (PASSOS, 2010:160). [grifo nosso]
\end{abstract}

O Código de Ética Profissional do Servidor Público Civil do Poder Executivo Federal está pautado em Regras deontológicas e utilitaristas. Outra teoria que fundamenta a ética é a Ética Teleológica, em que os resultados de ações cometidas justificam se a ação foi ética ou não. Os princípios convencionados como antiéticos são desconsiderados para a análise da atitude ética. A motivação desta teoria está em Aristóteles, com sua ética das virtudes, em que revela o significado da palavra 'virtude' como uma pré-disposição do ser humano para o cometimento do bem.

A virtude, segundo o autor, estaria no meio de dois extremos, em que o excesso constitui a deficiência moral, exemplo: valentia/prepotência (deficiência moral); coragem (virtude); covardia (deficiência moral). Nota-se, por meio desse exemplo, que a coragem, considerada virtude, está entre os dois extremos, os quais constituem deficiência moral (ARISTÓTELES, 1980 apud FARIAS, 2013:12). A virtude seria, então, o domínio racional sobre as emoções, sendo considerada virtuosa uma pessoa que se esforça repetidamente em busca da virtude. De acordo com Aristóteles, as virtudes aperfeiçoam-se com o hábito. Além de nortearem o bom convívio em relações interpessoais, conforme revela De La Taille:

[...] somente a vivência de relações sociais que se sustentam por relações de reciprocidade e respeito mútuo pode levar os indivíduos a compreender e legitimar tal reciprocidade e tal forma de respeito. Logo, para além de lições de moral que explicam e com as virtudes da justiça, da generosidade, da dignidade, da liberdade, por melhores que sejam, deve imperativamente haver uma "vida social" na qual tais virtudes regulem as relações interpessoais. (DE LA TAILLE, 2009:257)

Outra virtude, que merece ser aqui mencionada é a tolerância, citada por Lopes: 
a prática da tolerância deve começar em cada um de nós, com um exercício de coragem ao encarar as nossas limitações e assumir por elas a responsabilidade, sem nos culparmos. Sendo tolerantes com os nossos próprios defeitos, e animados pelo sincero propósito de nos modificarmos, começamos lentamente a compreender que os outros também merecem essa tolerância e essa compreensão que dedicamos a nós mesmos e que, por isso mesmo, sabemos ser suave e curativa como um bálsamo. E somente assim, depois de mobilizarmos a paz dentro de nós, podemos dedicar-nos a compartilhá-la com os outros (LOPES, 2004:3).

De acordo com Vaz (2011:445), tem-se também a virtude da justiça, considerada a mais alta das virtudes:

“Como hábito, porém, o ethos regido pelo critério do justo é a virtude, ou bem do indivíduo que se submete à norma da reta razão (orthos logos). Eis porque a justiça é a mais alta das virtudes na esfera do agir ético" (CALURI, 2011:72). Desta forma, verifica-se o grau de importância da justiça para o agir ético, o que corrobora com o que diz a ética aristotélica quando "propõe a superação do conflito pela prática das virtudes morais." (CALURI, op. cit.).

Caluri (op. cit:72,73) também afirma que "viver com ética é viver em conformidade com a justiça. [...] A justiça é o centro da reflexão ética".

Há também a concepção utilitarista da ética segundo Farias, que diz que "[...] o principal lema dos utilitaristas ingleses como Jeremy Benthan (1748-1832), John Stuart Mill (1806-1873) e Henry Sigdwick (1830-1900) pode ser interpretado da seguinte forma: 'o maior bem para o número maior possível de pessoas" (FARIAS, 2013:15).

Esta teoria é contrária à ética deontológica, pois os utilitaristas analisam as circunstâncias e são mais tolerantes, ao contrário dos deontologistas, que se apoiam no pensamento socrático. Os deontologistas são radicais em relação ao que é definido como ético, seguindo as normas fielmente em qualquer contexto, como, por exemplo, mentir jamais. Ao passo que para os utilitaristas, a mentira é permitida quando o ato for em benefício da maioria. 
Essas teorias revelam as diferentes linhas de entendimento a respeito do que deve ser considerado ético. Contudo, pode-se verificar que a promoção do bem social é o foco da ética.

De modo a ampliar esta pesquisa, traz-se à tona a definição de ética, conforme Mário Sérgio Cortella em entrevista ao programa do Jô, na Rede Globo de televisão, no dia 18 de março de 2013, onde explicou o conceito de ética em resposta ao entrevistador:

$$
\begin{aligned}
& \text { é um conjunto de valores e princípios que você e eu usamos para decidir as três } \\
& \text { grandes questões da vida, quais são elas: Quero? Devo? Posso? Isso é ética. Quais } \\
& \text { são os princípios que uso? Tem coisa que quero, mas não devo. Tem coisa que eu } \\
& \text { devo, mas não posso. Tem coisa que eu posso, mas não quero. (CORTELLA, 2013) }
\end{aligned}
$$

Logo após, o entrevistador Jô Soares questiona como a ética deveria ser definida, e o entrevistado responde: "pelo modular, exemplar, princípios da sociedade, sendo religiosos ou não". Afirmou também que "não existe ninguém sem ética", dando o exemplo de uma pessoa fraudadora, que para ele, essa pessoa tem uma ética contrária da considerada correta, o que a torna antiética.

O apresentador Jô Soares pergunta, ainda: “o que é moral, amoral e imoral?”. Cortella responde: "amoral é a pessoa que não pode decidir, escolher e julgar", e cita o exemplo de crianças até determinada idade, pessoas com algum tipo de patologia cerebral, pessoas consideradas dementes socialmente. "Já a moral é a prática de uma ética", e a ética, por sua vez, seria, segundo o entrevistado, “o princípio”.

Cortella segue dizendo: “portanto, eu tenho o princípio ético de não pegar o que não me pertence, meu comportamento moral é: se eu roubo ou não". O princípio se traduz em um moral. "Uma pessoa amoral teria de ser alguém incapaz de decidir, julgar e avaliar, aliás, a lei chama de incapaz. Você tem gente que é imoral, o que é imoral? Há pessoas que consideram um beijo entre dois homens imoral, outras pessoas consideram moral". E seguiu sua reflexão dizendo que "depende da moral que você pratica e ela está na referência da ética 
que você tem por trás e da época [...]; já a ética ela é sempre de uma época, de um grupo, mas ela tem uma tentativa de ser universal".

A luz do que foi dito por Cortella (2013), a moral é relativa, dependendo da concepção dominante do que é aceito como correto. Discussões que perduram ao longo do tempo, em meio à sociedade, como, por exemplo, o respeito às pessoas sem qualquer discriminação, têm por objetivo a conscientização de todos, como atitudes que deverão ser seguidas. Assim, tem-se a ética como tentativa constante de se tornar universal. A este respeito, Passos relata que

toda sociedade, por menor que seja e por menos desenvolvida que pareça, possui seus valores morais, que vão sendo ensinados a seus membros através da família, da escola, da igreja, dos meios de comunicação de massa. Isso porque eles desempenham um papel fundamental como elementos reguladores do comportamento das pessoas. Em outras palavras, como um elemento dominante do tipo de conduta necessária à sociedade. Logicamente, esses valores não são claramente impostos pela sociedade. O processo é de certa forma, sutil e dá-se lentamente. (PASSOS, 2010:25)

Sobre o comportamento moral, Vásquez (1992:5) aponta o seguinte conceito: “[...] moral vem do latim mos ou mores, "costumes" ou costumes", no sentido de conjunto de normas ou regras adquiridas por hábito. A moral se refere, assim, ao comportamento adquirido ou modo de ser conquistado pelo homem."

Em relação ao depoimento de Cortella (2013), Vazquez relata sobre o comportamento e a relação do homem e a moral, afirmando que

as respostas sobre o que é bom variam, evidentemente, de uma teoria para a outra: para uns, o bom é a felicidade ou o prazer, para outros, o útil, o poder, a autocriação do ser humano, etc. Mas, justamente com este problema central, colocam-se também outros problemas éticos fundamentais, tais como o de definir a essência ou os traços essenciais do comportamento moral à diferença de outras formas de comportamento humano, como a religião, a política, o direito, a atividade científica, a arte, o trato social, etc.

Os homens não só agem moralmente (isto é, enfrentam determinados problemas nas suas relações mútuas, tomam decisões e realizam certos atos para resolvê-los e, ao mesmo tempo, julgam ou avaliam de uma ou de outra maneira estas decisões e estes atos), mas também refletem sobre esse comportamento prático e o tomam como objeto da sua reflexão e do seu pensamento. (VAZQUEZ, 1992:2,3) 
Os valores morais vão sendo repassados através de um processo de comunicação em que Silva (2009) revela ser o resgate da compreensão do ser humano como alguém que possui códigos psicossociais (linguísticos) e psicobiológicos (seu comportamento que é a expressão não-verbal). Dessa forma, pode-se entender que os valores morais não só foram criados com a intenção de discursar, mas também como um meio de se estabelecer a ordem que é necessária para a boa convivência entre os indivíduos, evitando o estabelecimento do caos. Ainda em relação a esse assunto, Vasquez relata que

a ética é a teoria ou ciência do comportamento moral dos homens em sociedade. Ou seja, é a ciência de uma forma específica de comportamento humano. Assim, "o ético transforma-se [...] numa espécie de legislador do comportamento moral dos indivíduos ou da comunidade. [...]. Desta maneira temos, pois, de um lado, atos e formas de comportamento dos homens em face de determinados problemas, que chamamos morais, e, do outro lado, juízos que aprovam ou desaprovam moralmente os mesmos atos. Mas, por sua vez, tanto os atos quanto os juízos morais pressupõem certas normas que apontam o que se deve fazer (VASQUÉZ, 1992:1, 3 e 5).

Quando a sociedade está em crise, no sentido de que perdeu o cerne dos valores

fundamentais para sua organização pacífica, ainda assim, o sentimento de sobrevivência dentro da moralização surge como necessidade. É o que revela Passos:

Nossa sociedade vive na atualidade uma redescoberta da ética. Há exigências de valores morais em todas as instâncias sociais, sejam elas científicas, políticas ou econômicas. Certamente essa situação não se dá por acaso; basta observamos que ela surge no mesmo momento em que a sociedade passa por uma grave crise de valores, identificada pelo senso comum como falta de decoro, de respeito pelos outros e de limites e, pelos estudiosos, como dificuldades de os indivíduos internalizarem normas morais, respeito às leis e regras sociais. (PASSOS, 2010:21)

Essas exigências morais feitas pelas pessoas são as reivindicações de seres humanos que, como humanos, são constituídos de sentimentos que exigem a presença de valores morais que possam garantir a ordem e o respeito no tratamento para com o outro e a si mesmo. Em relação à aproximação conceitual, Passos relata:

$\mathrm{Na}$ atualidade a palavra virtude está em desuso e a palavra moral foi substituída por ética, por ser mais geral e menos identificada com a religião. Entretanto, mantém inalterada a certeza de que a vida humana é constitutivamente moral, pois ela se estrutura em torno de valores. Os projetos de vida sejam eles individuais ou coletivos, configuram-se a partir de ideias que outra coisa não são senão valores. (PASSOS, 2010:22) 
Diante do exposto, verifica-se que as ações partem de valores que quando internalizados conduzem às atitudes praticadas pelos seres humanos. Por isso, a importância do estabelecimento de valores morais que conduzam as pessoas para o bom relacionamento. A autora afirma que a moral foi substituída pela ética, mas as duas têm significados diferentes, apesar da etimologia da palavra moral explicar que ela vem do latim mores, que quer dizer costume, conduta, modo de agir. Passos segue dizendo, com base em sua interpretação do teórico Vásquez, "que a moral, enquanto norma de conduta, refere-se às situações particulares e quotidianas, não chegando à superação desse nível. A ética destituída do papel normatizador, ao menos no que diz respeito aos atos isolados, torna-se examinadora da moral" (PASSOS, 2010: 22).

A ética estuda a moral, teorizando comportamentos, criando o suporte necessário para o entendimento do valor moral. Diante do exposto, tem-se concepções diferentes, em que a moral assume o status de objeto e a ética de ciência. Deduz-se que a Ética é a ciência da moral, como afirma Vasquez (1975:12): “a ética é a ciência que estuda o comportamento moral dos homens na sociedade". Porém, há situações em que a ética também pode ser considerada de maneira distorcida, como sendo da dissimulação e do engodo. Conforme explica Matos,

as distorções conceituais, criadas para que a Ética se ajuste a circunstâncias e interesses egoísticos, fazem lembrar o papa Pio XII ao denunciar o "mal do século": "O homem criou Deus a sua imagem e semelhança." A ética é a ciência da verdade; não existe uma ética da mentira, nem a meia-ética. A Ética e a verdade são a essência da consciência humana. Ninguém lhes pode ser indiferente. (MATOS, 2008:2)

Para o autor, a ética e a verdade, por habitarem a consciência, vêm de dentro, e têm a ver com o 'ser'. Ou, se é ou não se é! Logo não têm 'meia-ética' e nem ética distorcida por mentira. Se é ética, ela deve estar pautada na verdade. Matos segue revelando o que foi dito até aqui em relação a importância do exercício ético para o bom convívio em sociedade.

Não há possibilidade de vida social sem que haja observância de princípios éticos. A sociedade apoia-se em três conceitos, seus pilares éticos: é essencial que ela seja 
justa - que haja oportunidade para todos; é necessário que ela seja livre - que a vontade educada torne a liberdade responsável; é vital que ela seja solidária - que haja compromisso com o bem pessoal e o bem comum. (MATOS, 2008:2)

Nessa dimensão, o teórico se refere a uma Sociedade eticamente comprometida com o respeito à dignidade humana. O ideal seria que todas fossem, pois sociedades que primam pela sua maior riqueza, o material humano, são sociedades mais promissoras e felizes. Matos (2008: 3) revela que “a Ética está na essência da cultura coorporativa e a Educação é o fator determinante de sua educação e de garantia de excelência. A educação e a cultura éticas tornam a sociedade ética". Ao passo que, se falta o respeito, pode-se incorrer no que revela Azevedo et al., (2012:136): “expressar-se com a intenção de oprimir, humilhar ou ofender alguém repetidas vezes é bullying”. Logo, além de ser falta de ética constitui também prática criminosa, que aniquila o bom relacionamento em sociedade.

Eis o desafio das comissões de ética: educar para a ética, haja vista este princípio não estar sendo seguido pelas organizações. Matos (2008:3) afirma que "valorizam-se exteriorizações, o marketing da ética, a aparência do ser. Daí os modismos dos códigos de ética e de suas inconsequências. São imprescindíveis a conscientização, a gestão e a estratégia, não o código".

É necessário que haja o marco regulatório, embora de nada valerá se não for seguido de uma prática educativa persistente a respeito da ética, que, portanto, motive uma cultura ética. Matos explica porque a ética é rejeitada:

Certo dia, a Ética desceu do Olimpo na forma de uma linda mulher e dirigiu-se a um reino poderoso. Todos ao vê-la, à distância, ficavam maravilhados, mas à medida que se aproximava, fechavam-lhe a porta. A Ética tentava comunicar-se, mas em vão: ninguém queria defrontar-se com ela. Bastava sua visão longínqua. Finalmente, acabrunhada, ao retirar-se, encontrou a Verdade, que se espantou com a sua profunda tristeza: - "Que foi, minha irmã? O que tanto a magoou? -"Cheguei em missão de paz, mas ninguém quis receber-me”, disse a Ética, não entendendo as razões porque foi rejeitada. - "Olhe-me de frente! - Adverte a Verdade. Ninguém, nem mesmo você, minha cara Ética, foi capaz de perceber a Verdade: nós somos espelhos. As pessoas têm medo de se verem refletidas em nós." (MATOS, 2008:4). 
Conforme já visto, a ética deve pautar as relações pessoais de modo a proporcionar o bom convívio entre as pessoas. Até aqui foram utilizados argumentos visando ao suporte teórico para a ética individual, uma vez que, desse assunto, parte-se para o entendimento macro de como alcançar a ética institucional. Segundo Bittar (2010:130), a teoria assim revela:

A penetração da ideia de moralidade nos âmbitos privado, individual e público é um mister social. Para além de se pensar que simplesmente os esforços individuais são capazes de erradicar os modelos antiéticos da sociedade, para além de se considerar que somente as entidades públicas são responsáveis por mudanças morais na sociedade, deve-se entrever que todas as instituições sociais (públicas e privadas), ao lado dos indivíduos, devem se afinar no sentido da conquista da cultura da moralidade. Assim, como a moralidade é algo importante para a administração da res publica (moralidade administrativa), é também para as relações entre particulares. [grifo nosso]

É necessário que haja um equilíbrio entre os valores do indivíduo e da coletividade, na figura do corpo institucional, logo,

somente a postura equilibrada que permite a identificação de uma cultura colonizadora dos instintos extremistas (extremo coletivista, que massacra a identidade individual; extremo individualista, que impede o crescimento da consciência coletiva) seria capaz de estabelecer a equitativa sensação de justo meio nos interesses sociais, institucionais, privados e públicos, individuais e coletivos (op. cit:132).

Em relação a uma ética das instituições, Bittar desejando fundar uma ordem de raciocínio para designar realidades específicas de contemporaneidade, cita Rawls (1995:254) ao dizer que ele forjou uma proposta teórica neocontratualista que se propagou pelos quatro continentes, e que conquistou a mentalidade dos principais governos hodiernos.

Trata-se de uma ética deontológica, porém diferenciada por não se restringir a enfatizar somente os deveres, mas sobretudo os direitos, ou melhor trata-se de um estudo que enuncia e grifa a importância dos deveres das instituições como molas propulsoras dos direitos dos cidadãos ( sic). Isso tudo porque se parte da tese da necessidade do comum para a sobrevivência e o desenvolvimento do individual. (BITTAR, 2010:429)

Bittar (op. cit.) reforça que isto ocorre porque a ética importa enquanto problema francamente social que se destaca na medida em que a organização contratual da sociedade requer determinados padrões de comportamento em sociedade. Portanto, a questão da ética 
institucional não só comunica a harmonia de seus colaboradores, como também reflete a postura de determinada organização frente a tensões éticas.

Em relação a esta questão de ética institucional, Cortella (2013:136) diz que "há empresas que têm uma visão estratégica de futuro, em que há uma conexão muito forte entre ética e negócios. Há outras, no entanto, que encaram a ética como cosmética e transformam a responsabilidade social em mero mecanismo de fachada". O estudioso revela que a ética cosmética não comunica a realidade da organização, uma vez que está voltada para a prestação social, que não reflete a postura interna de seus integrantes, e portanto, o clima organizacional.

Em relação a essa temática, Patrus-Pena e Castro (2010) expõem que a ética empresarial pode ser um atrativo para clientes exigentes que prezam a ética em suas atuações, ao ponto de fidelizar estas pessoas, e assim fazer com que a organização seja mais competitiva em meio aos concorrentes.

Tanto Cortella como Patrus-Pena e Castro defendem a visão de que uma empresa ética é uma empresa que se prepara estrategicamente para o futuro, apoiada em sua preocupação com os negócios e a imagem organizacional junto aos clientes.

Uma das preocupações do Governo em instituir as comissões nos órgãos se deve ao anseio de moralização do ambiente laboral e na melhor forma de prestação dos serviços públicos, embora haja outros motivos pelos quais as comissões de ética, de um modo geral, foram criadas, conforme a seguir. 


\subsection{Gestão Pública e a Introdução da Atividade Administrativa Ética no Ordenamento Administrativo Brasileiro}

Esta seção apresenta o novo modelo de administração pública, a partir do pensamento internacional, que tem como característica a diminuição do Estado, o movimento do gerencialismo, o corte de gastos públicos, a responsabilização de políticos, além de uma gestão baseada em resultados. Neste subitem, poder-se-á perceber como se deu a evolução da Gestão Pública, como acontece a New Public Management na história da Administração Pública brasileira, e uma das bases dessa evolução, que é a construção de um Sistema de Gestão da Ética. Assim, tem-se por objetivo contribuir para a obtenção de respostas ao problema delimitado, uma vez que analisar a Comissão de Ética da Universidade de Brasília e a compreensão da dimensão como prática educativa impôs uma análise cuidadosa na investigação. Para isso, buscou-se a fundamentação em autores, tais como, Martino Júnior (2010), Pereira (1997), Mendes (2010), Peci et al., (2014).

Antes do modelo gerencial, que prima pela gestão eficiente e mais transparente remetendo à ética, o modelo vigente no país era o burocrático, o qual ao longo dos anos demonstrou-se ineficiente, corruptível e distante dos anseios da sociedade, conforme revela Amorin:

O modelo burocrático produziu ao longo dos anos, uma imensa e onerosa estrutura, isolada da sociedade e voltada para si mesma, imobilizada pela obediência a rígidos procedimentos e, por conseguinte, incapaz de fazer frente às mudanças do ambiente, e impermeável às reivindicações da sociedade. O insulamento burocrático, a ineficiência, a despreocupação com os resultados e o descompromisso com a sociedade tornaram-se seus principais atributos. Suas intenções moralizantes frustraram-se, face ao excessivo formalismo dos controles internos e a falta de transparência dos atos públicos, abrindo espaço para a formação interna de grupos de interesse e para a ampliação dos níveis de corrupção no aparelho estatal. A reação a essa situação irrompeu sob a forma de um conjunto de propostas de transformação do Estado e de suas relações com a sociedade que buscavam superar as limitações impostas pelo modelo burocrático. (AMORIN, 2000:96) 
Na busca pela superação dos limites impostos pelo modelo burocrático que surgiu a Reforma Gerencial, a qual “promoveu mudanças nos paradigmas da administração pública brasileira, com a inserção de conceitos e técnicas gerenciais, rompendo assim, o obsoleto modelo burocrático e patrimonialista" (MARTINO JUNIOR, 2010:1).

Pereira (1997) relata que a reforma do Estado foi tema central em todo o mundo nos anos 90, haja vista o processo de globalização vigente, bem como a crise do Estado, sofrida por quase todo o mundo em princípio da década de 70, com confirmação da crise nos anos 80. Este mesmo autor acrescenta que "no Brasil, a reforma do Estado começou nesse momento, em meio a uma grande crise econômica, que chega ao auge em 1990 com um episódio hiperinflacionário" (PEREIRA, 1997:5).

Em relação a tal período, Mendes relata o contexto em que o Brasil se encontrava, e que impulsionou o país para a implementação do Sistema de Gestão da Ética, uma vez que está sendo observado internacionalmente em relação a suas ações para o cumprimento de seus acordos com os organismos, conforme o que segue:

No início dos anos 2000, em meio ao processo de reestruturação do Estado, o Brasil ratifica três convenções internacionais contra a corrupção, no âmbito dos foros multilaterais. Em 2000, promulga a Convenção sobre o combate da corrupção de funcionários públicos estrangeiros em transações comerciais internacionais da Organização para a Cooperação e o Desenvolvimento Econômico - OCDE; em 2002, a Convenção Interamericana Contra a Corrupção da Organização dos Estados Americanos - OEA, em 2006, a Convenção das Nações Unidas - ONU (MENDES, 2010:39).

Cabe salientar que tal processo de reestruturação ocorre após o período do mandato presidencial de 15.03.1990 até 29.12.1992, do então Presidente da República Fernando Collor de Mello. Sobre isso, Amorin relata que

nos anos 93 e 94, sob o impacto negativo do Governo Collor, buscou-se, sem grande êxito, elaborar e implantar um código geral de ética para os servidores federais, visando coibir práticas explícitas de má conduta no serviço público.

Em 21 de agosto de 2000, o Presidente da República aprovou o Código de Conduta para a Alta Administração Federal. (AMORIN, 2000:101) 
A instituição de Comissões de Ética surge pelo reconhecimento de que o aparato legal não é suficiente para promover a ética. Iyer revela em que contexto político surge a Comissão de Ética Pública:

During the 1990s, conflict-of-interest scandals in Brazil weakened public trust in civil servants. Cronyism, nepotism, and special interests made processes like procurement, privatization, and employment inefficient. In 1999, President Fernando Henrique Cardoso created a Public Ethics Commission to confront those problems (IYER, 2013).

Na época, o pós-impeachment do ex-presidente Fernando Collor de Mello foi ápice das denúncias relativas a corrupção, potencializando a falta de confiança do cidadão brasileiro em relação ao serviço público. O ex-presidente Fernando Henrique Cardoso criou a Comissão de Ética Pública, como passo inicial para a promoção da ética em órgãos públicos.

Foi no contexto do pós-impeachment que a reforma do Estado se tornou imperiosa, como revela Pereira:

A reforma administrativa, entretanto, só se tornou um tema central no Brasil em 1995, após a eleição e a posse de Fernando Henrique Cardoso. Nesse ano ficou claro para a sociedade brasileira que essa reforma tornara-se condição, de um lado, da consolidação do ajuste fiscal do Estado brasileiro, e, de outro, da existência no país de um serviço público moderno, profissional e eficiente, voltado para o atendimento das necessidades dos cidadãos. (PEREIRA, 1997:5)

O objetivo dessa reforma, segundo Pereira (2003:11) era o de "[...] reconstruir o Estado brasileiro, por meio de uma ampla reestruturação (com descentralização, privatização e valorização da esfera pública não governamental), do controle fiscal e da implantação de técnicas gerenciais que melhorassem a performance do Estado". Esta reforma foi partidária ao New Public Management - NPM, que visa à diminuição da máquina estatal, o corte de gastos públicos, a responsabilização de políticos, além de uma gestão baseada em resultados. Entretanto sua proposta não foi a primeira, conforme revela Peci et al.:

\footnotetext{
${ }^{1}$ No Brasil, durante a década de 1990, escândalos sobre conflitos de interesse levou a um enfraquecimento da confiança dos cidadãos na função pública. Compadrios, lobbies (interesses particulares, lobbying) e nepotismo tornaram o/a aprovisionamento/aquisição, a privatização e o emprego processos ineficientes. Para combater estes problemas o Presidente da República Fernando Henrique Cardoso cria em 1999 a Comissão de Ética Pública. [tradução livre]
} 
Além da adoção acrítica do receituário internacional em prol da NPM, no processo da Reforma do Aparelho de Estado de 1995, não foi recorrente a lembrança de que todas as manifestações semelhantes e anteriores buscaram, também, a eficiência da administração pública - cada qual, é certo, ao seu modo, como redução de gastos, diminuição ou criação de novas estruturas, descentralização ou centralização. $O$ conceito de eficiência, pois, pouco contribui para uma iniciativa de reforma, já que é impreciso. Não se tem notícia de reforma feita com vistas à ineficiência da administração pública, porém nem todas as que empunharam a bandeira da eficiência conseguiram, independentemente dos métodos empregados, alcançá-la em um grau aceitável para os próprios governos (PECI et al., 2014:52).

A Reforma do Aparelho de Estado de 1995 "que defendia com entusiasmo a transparência e eficiência" (PECI et al., op. cit.:39) corroborava com os ideais do movimento New Public Management, o qual trouxe para a administração pública um novo modelo de gestão baseado na descentralização do Estado, bem como outras características principais. “A NPM é ideologicamente marcada pelo neoliberalismo e busca tornar as organizações públicas similares às privadas", assim como o "principal foco são as práticas intraorganizacionais" (op. cit.:42). Tal movimento não foi amplamente recepcionado, por causa da descentralização, por ser a reforma "vista como perda de controle, pois ameaça a ordem burocrática, uma vez que modifica a estrutura de importância e prestígio profissional e político (op. cit.:47). Os autores acrescentam que

No Brasil, é cíclico o embate entre descentralização e centralização das reformas brasileiras como condicionante natural do grau de autonomia a ser concedido pelo Estado. A um período altamente centralizado, segue-se uma iniciativa de descentralização, a qual se segue outro período de centralização. Não foi diferente com a Reforma do Aparelho de Estado de 1995, que apresentou propostas em que a autonomia era ponto central. (op.cit)

Aliado ao aqui exposto, Gonçalves relata que

por outro lado, a nova gestão pública procura colocar à disposição do cidadão instrumentos eficientes para possibilitar uma fiscalização dos serviços prestados e das decisões tomadas pelos governantes. As ouvidorias instituídas nos Órgãos da Administração Pública direta e indireta, bem como junto aos Tribunais de Contas e os sistemas de transparência pública que visam a prestar informações aos cidadãos sobre a gestão pública são exemplos desses instrumentos fiscalizatórios.

Tais instrumentos têm possibilitado aos Órgãos Públicos responsáveis pela fiscalização e tutela da ética na Administração apresentar resultados positivos no desempenho de suas funções, cobrando atitudes coadunadas com a moralidade pública por parte dos agentes públicos. Ressaltando-se que, no sistema de controle atual, a sociedade tem acesso às informações acerca da má gestão por parte de alguns agentes públicos ímprobos. (GONÇALVES, 2011:4) 
Conforme a explanação de Gonçalves (2011), as Ouvidorias, Tribunais de Contas e os sistemas de transparência pública contribuem como instrumentos fiscalizatórios e, portanto, para a atividade administrativa ética no citado modelo de gestão pública. Outras ações que contribuem para a introdução da atividade administrativa ética é o investimento da alta administração em preparar seus agentes públicos para agir em prol do Sistema de Gestão da Ética. Dessa forma, a instituição do código de ética ajuda a balizar a atuação de seus agentes, de modo mais eficaz, e assim cobranças de um comportamento condizente com a moralidade administrativa são facilitadas.

Em relação a tais ações para a promoção da ética, Mendes expõe que

não obstante, existe uma crescente mudança no sentido da conscientização para a ética, perceptível tanto para os servidores públicos quanto para a sociedade organizada. O fato não pode ser atribuído exclusivamente ao Sistema de Gestão da Ética. É o conjunto de ações com diferentes atores e políticas que está promovendo mudanças incrementais. (MENDES, 2014:6)

Do exposto, extrai-se que há uma premente necessidade de capacitar os agentes públicos para que tais órgãos e comissões funcionem de maneira eficaz e eficiente para a promoção da ética. Esta concepção de preparo dos agentes públicos é ratificada por Caluri (2011:74), ao afirmar que, “dentre vários requisitos do profissional ético, podemos destacar os mais importantes: a lealdade, a moderação e a probidade". Aqui percebe-se que a probidade é um requisito essencial ao profissional que deseja ser ético. Para que ocorra esse ajustamento, é necessário que o indivíduo seja educado para adquirir tais valores, através de um processo de reflexão contínuo e facilitado por constantes ações educativas. Gonçalves acrescenta ainda que outra forma para moralizar a administração tem sido a aplicação da Leis como por exemplo, a de Improbidade Administrativa (Lei $n^{\circ}$ 8.429/92) e da Lei de Responsabilidade Fiscal (Lei Complementar $n^{\circ}$ 101/00) leis que possibilitam a responsabilização dos infratores, permitindo à sociedade reaver uma gestão sem vícios e voltada à sua finalidade maior que é o interesse social (GONÇALVES, 2011). 
Verifica-se que o modelo gerencial trouxe a proposta de dissipar antigos paradigmas consubstanciados em uma burocracia adulterada e eivada de corrupção e desvio de finalidade. Gonçalves (2011) afirma que é assim que se gere a administração pública, com ética e eficiência.

Todas as ações reveladas pela reforma gerencial, incluindo as ações de outros países, demonstram a necessidade das sociedades em ter uma Gestão Pública que administre suas atividades eticamente. Certo é que o estabelecimento da ética na sociedade proporciona o bom convívio entre as pessoas, situação esta também reconhecida e estabelecida pela Carta Magna, ao explicitar a intenção de harmonia.

\subsection{A Nova Gestão Pública: Criação de Comissões de Ética no Contexto da Descentralização da Gestão Intergovernamental}

Em decorrência da crise do petróleo e à grande crise financeira internacional que pôs fim à era de prosperidade que se iniciara depois da $2^{\mathrm{a}}$ Guerra, em meados dos anos 70 , surge um marco no novo contexto dos governos. Trata-se de um momento econômico que gerou governos com menos recursos e mais déficits, além de colocar o modelo de sucesso então vigente, o do Welfare State, em xeque. Com a diminuição dos benefícios sociais, desemprego em alta e renda em baixa, ocorreu um aumento de pressão sobre as estruturas governamentais, momento em que o modelo burocrático passou a ser visto como lento e excessivamente apegado a normas (ABRUCCIO, 1997). A burocracia não respondia mais às necessidades da sociedade contemporânea (POLLITT, 2010). 
Nesse contexto, em que passaram a ser buscadas alternativas ao modelo burocrático, surge o movimento conhecido por New Public Management - NPM, que no Brasil foi denominado como Nova Gestão Pública.

$\mathrm{Na}$ sua primeira fase, a de desenvolvimento, que no Brasil envidou inúmeros esforços, os proponentes do NPM tinham como principal objetivo a economia-eficiência (produtividade) e defendiam uma espécie de "modelo gerencial puro" (managerialism) aplicado à administração pública, nos moldes das práticas realizadas na iniciativa privada, em sua primeira fase. No eixo central dessa nova proposta estavam três conceitos. De acordo com Abrucio (1997) buscava-se o aumento da produtividade e eficiência no setor público (fazer mais com menos), com foco no corte de custos, principalmente de pessoal; assim como, o aumento da consciência dos servidores sobre o valor dos recursos públicos (utilização e gasto racional); e a adoção de instrumentos de avaliação de desempenho organizacional.

Esse novo modelo também estimulava e exigia um modelo de descentralização da gestão intergovernamental, que propagava a ideia de transparência e voltava a atenção para os valores inerentes à administração pública. Nesse momento, a discussão sobre a criação de entes descentralizados como os conselhos e comissões tornaram-se um dos grandes apelos da Administração Pública (SILVA, 1999). Segundo Radim (2010:609), a criação das comissões no sistema federal é uma projeção dessa descentralização de gestão, dado que "as comissões são ferramentas estruturais que podem ser usadas para quaisquer quantidades de propósitos intergovernamentais. São frequentemente uma ferramenta de integração horizontal, mas muitas vezes podem deslocar o poder para um nível centralizado".

As Comissões de Ética foram criadas pelo governo federal para instituir a gestão democrática, de modo a minimizar a antiga tradição totalitária, que não abria espaço para demais participações quanto a decisões tomadas em relação à gestão da ética nos órgãos do poder executivo federal. Em princípio, a Comissão de Ética da Presidência da República - 
CEP/PR era uma instância de consulta do Presidente, mas depois passou a ter funções executivas, como, por exemplo, a liderança e coordenação de um sistema de Gestão de Ética institucionalizado em todo o país, por intermédio de órgãos do Poder Executivo Federal. Observa-se que a CEP - Comissão de Ética da Presidência da República foi criada em Maio de 1999, por Decreto do Presidente da República, como decorrência de proposta específica do Conselho de Reforma do Estado, e,

a princípio, ela se restringiu à instância de consulta do Presidente da República em
questões de natureza ética. Com a aprovação do Código de Conduta da Alta
Administração Federal, ela passou a ter também funções executivas. Com isso
agregou também o papel de liderança e coordenação na promoção de ações para
assegurar a adequação e efetividade dos padrões éticos em 193 entidades e órgãos
que integram o Executivo federal. (PEREIRA, 2002:13)

A ideia da descentralização, no entanto, não é algo recente, pois desde os anos 50 é objeto de estudo no campo da Administração. De acordo com Silva (1999), a descentralização, neste caso, promove a proximidade das decisões por serem efetuadas em nível local, podendo resolver problemas característicos de cada organização. Dessa forma, “[...] descentralizar implica em um processo que fortalece as estruturas políticoadministrativas locais efetivarem a formulação das políticas de natureza local” (MACIEL, 2007:13). Matos (2008) revela que a descentralização visa ao deslocamento da consideração convencional de onde está a autoridade para onde está a informação e os resultados, e diz ainda que, “é a autoridade do conhecimento que conduz à decisão. Deste modo, o que antes era a obediência cega à hierarquia, hoje tende para a auto direção e o autocontrole - sinais de maturidade corporativa” (MATOS, 2008:60).

A partir da Comissão de Ética da Presidência da República, daqui pra frente, CEP, deu-se início a uma rede de ética nos órgãos públicos federais de forma descentralizada objetivando a instrução e fiscalização de questões ligadas à ética. As Comissões de Ética Setoriais têm a sua autonomia legalmente instituída, no entanto, estão vinculadas ao normativo do órgão central da Presidência da República, CEP/PR. 
Há décadas a gestão intergovernamental era tratada em relações verticais e poucas vezes em relações horizontais entre os níveis de governo e de modo direto e simples “[...] também ficou claro que muitos dos comportamentos descritos nos sistemas federais eram encontrados, além disso, em sistemas políticos unitários” (RADIM, 2010:597).

Esta antiga estrutura, segundo Radim (op.cit.:598) permanece como base para as atuais análises das mudanças ocorridas. O formato inicial de um único nível de governo se revelou insuficiente para atender as diversas demandas que foram surgindo ao longo do tempo, de modo a necessitar de uma nova percepção.

\begin{abstract}
Os gestores perceberam que o paradigma tradicional de comando e controle que acentua a autoridade dos indivíduos no topo da hierarquia não fornecia uma estrutura adequada para lidar com os principais assuntos encontrados nos debates intergovernamentais nos Estados Unidos e em outros países. Nem apreende a tensão entre unidades governamentais nacionais e locais em sistemas unitários. Esse é o debate autonomia versus controle - pergunta-se em que medida os níveis mais elevados de governo deveriam empoderar os níveis mais baixos do governo e deixar o caminho livre para que realizem suas tarefas. Isso envolve a questão contínua sobre o nível de descentralização a ser desenvolvido [...]. (RADIM, 2010:600)
\end{abstract}

Desse modo, verifica-se a direção de uma integração entre indivíduo e organização no alcance dos alvos pré-estabelecidos. O que é mais vantajoso do ponto de vista organizacional, haja vista que a não verticalização de conhecimento proporciona maior participação de todos os envolvidos e, portanto, maior inserção de criatividade e conhecimento na resolução de problemas. Para esta compreensão, Matos (2008:60) revela que objetivos e metas são fixados em uma integração indivíduo-organização, ao
contrário da prática tradicional da descentralização administrativa. A comunicação,
antes voltada para um só sentido pela linha hierárquica, é orientada em todos os
sentidos (vertical, horizontal e sistêmico). Todos precisam estar informados para
poderem participar e espontaneamente poder contribuir com suas habilidades e
conhecimentos. Ainda em relação ao Sistema de Gestão da Ética, pode-se dizer que é composto por vários órgãos participantes, e de forma descentralizada, e, por ser assim, auxilia a difundir essa conscientização ética, que deve nortear a convivência nas instituições, conforme revela Costa (2003:1): 
o relacionamento interpessoal - necessidade social, conforme Maslow (2000), ou fator higiênico, segundo a teoria herzbergiana - deve se pautar pelo diálogo, sem o qual, as relações entre os indivíduos resvalam para conflitos vários. A dignidade jamais deve ser esquecida ou colocada em segundo plano. A prática da humanização deve ser observada ininterruptamente. O comportamento ético deve ser o princípio de vida da organização, uma vez que ser ético é preocupar-se com a felicidade pessoal e coletiva.

A inovação, que antes era rejeitada por medo de se perder o controle, poder, da direção da organização, em uma centralização autoritária, atualmente vem sendo substituída pela descentralização, que garante a valorização da mão de obra humana, dignificando o homem e garantindo a continuidade dos trabalhos e a sobrevivência da organização. A esse respeito Matos (2008:60) afirma que

a inovação, que era considerada ameaça à segurança e à normalidade, reprimindo-se as ideias novas, hoje é a própria garantia de sobrevivência. A organização precisa ser inovadora, o que exige que a gerência seja criativa. Este é o cenário ético da gestão direcionada ao futuro.

As Comissões de Ética viabilizam a participação dos indivíduos, integrantes dessas comissões, no Sistema de Gestão da Ética, bem como descentralizam e simplificam a estrutura burocrática que engessa as ações do governo e que mesmo que estejam submetidas a órgãos centrais são dotadas de autonomia ao ponto de terem prerrogativas deliberativas e fiscalizatórias, além de efetivarem a formulação das políticas de natureza local. É nessa direção, que a ideia das comissões de ética tornou-se instrumento referencial que pode avaliar os alcances e possibilidades de suas práticas, a partir de suas políticas implementadas, e adotar soluções mais adequadas à sua realidade.

\subsection{Gestão da Ética como Prática que Favorece a Gestão Democrática}

Neste tópico destaca-se a importância de praticar a ética nos órgãos públicos, posto que eles alcançam o cidadão de forma mais próxima, e, assim sendo, permite que a sociedade, de uma forma geral, sinta a Gestão Democrática do Governo Federal. Esse patamar 
é alcançado mediante a capacitação dos seus servidores. O tópico tem ainda por objetivo contextualizar a importância das Comissões de Ética para o alcance da gestão democrática no âmbito das relações de trabalho.

O conhecimento da ética e a sua prática favorecem a implementação da gestão democrática em órgãos públicos, posto que um comportamento ético é o meio mais eficaz para a manutenção de bons relacionamentos. Dessa forma, existe a necessidade de implementação de uma pedagogia voltada para o exercício contínuo da atitude ética no ambiente laboral, bem como a afirmação das Comissões de Ética nos órgãos federais. Segundo Soares,

\begin{abstract}
A gestão da ética transita por um eixo bem definido. Em uma de suas pontas, temos os valores e princípios éticos que se deseja norteadores da administração pública. No meio as regras de conduta, um caminho prático para que os valores e princípios sejam observados. Na outra ponta a administração, que deve funcionar como um instrumento garantidor da eficácia dos valores e regras. (SOARES, 2002:17)
\end{abstract}

A gestão da ética eficaz se dá por meio do sentimento de confiança da sociedade em relação às atitudes dos servidores públicos e da capacitação desses servidores no que diz respeito a agir de forma ética. Diante do exposto, verifica-se a importância de programas educativos, que capacitem os servidores. Sobre o tema, Sovienski e Stigar afirmam ser necessário

[...] reconhecer o potencial humano como o recurso estratégico mais importante para o desenvolvimento e sucesso institucional; envolver e comprometer todos os servidores no trabalho de melhoria do serviço público, com ênfase na participação dos mesmos no processo de gestão, reconhecer que é necessário capacitar e profissionalizar o servidor para que desenvolva e utilize seu pleno potencial de modo coerente e convergente com os objetivos estratégicos da instituição [...]. (SOVIENSKI e STIGAR, 2008:55) [grifo nosso]

“O termo gestão da ética é utilizado para denominar a política pública para a promoção da ética. Sistema de Gestão da Ética do Poder Executivo federal” (MENDES, 2014:16). A promoção da ética aqui mencionada envolve as relações de trabalho. 
O Sistema de Gestão da Ética do Poder Executivo Federal é um sistema mais abrangente, haja vista partir da Comissão de Ética da Presidência da República - CEP/PR para as Comissões de Ética locais. A esse respeito, Almeida (2007:69) afirma que “[...] para os sistemas formais influenciarem o comportamento, eles devem ser parte de um sistema mais abrangente, culturalmente coordenado, que apoie a conduta ética em cada momento". Esta citação aplica-se em parte ao caso concreto das Comissões de Ética locais, uma vez que elas apresentam autonomia em suas deliberações. Portanto, não há que se falar de um controle finalístico por parte da CEP/PR, pois não se trata de um órgão recursal dessas comissões locais.

Verifica-se a necessidade do Sistema de Gestão da Ética, posto que "a maioria das pessoas é o produto do contexto ao qual descobrem pertencer. Elas tendem a olhar para cima e para os lados, e fazem o que os outros ao redor fazem ou esperam que elas façam" (ALMEIDA, 2007: 69).

Matos faz algumas recomendações essenciais ao modelo de gestão da ética. Em primeiro lugar, ele diz ser necessário definir a filosofia da empresa: “é imprescindível que todos na empresa tenham plena consciência dos valores fundamentais que orientam os comportamentos. Significa tornar palpáveis os traços fundamentais da cultura corporativa" (MATOS, 2008:122).

Em segundo lugar, o autor (op.cit) diz ser necessário “definir as diretrizes éticas. Explicitar os padrões de comportamento esperados, consoante aos valores da cultura corporativa". A esse respeito, o código, ele recomenda criar instrumentos institucionais para a gestão da ética, uma das propostas desta Dissertação, haja vista o levantamento dos dados na análise de conteúdo e na pesquisa bibliográfica. Em relação a esses instrumentos, Matos (op.cit.:122) acrescenta que "a viabilização do comportamento ético depende fortemente da instituição de meios adequados. Sem os espaços à reflexão e ao exercício participativo da 
decisão, a gestão torna-se centralizadora e autocrática. Nesses casos, a cultura corporativa fechada inibe a gestão da ética".

Em relação à cultura corporativa fechada, esse aspecto é um dificultador dos trabalhos, embora o fato de que a Comissão de Ética conta com sua instituição por Decreto Presidencial $n^{0}$ 6.029/2007 já abre possibilidades de uma inserção nesta cultura "fechada". O autor revela ainda, ser importante o desenvolvimento contínuo, por meio da educação, para alcançar a consciência ética. Em relação a esta orientação, Matos (2008:122) diz ser necessário, “exercícios permanentes de percepção e competência criativas por intermédio de técnicas e metodologias dinâmicas de aprendizagem que reforcem os valores e a práxis da ética no trabalho, contribuindo para a consolidação de uma cultura corporativa aberta".

Soares (2002:17) revela a importância da educação para a gestão da ética, ao dizer que, "a gestão da ética compreende o exercício de quatro funções básicas: normatização, educação, monitoramento e aplicação de sistema de consequências".

A função da normatização é tornar as informações as mais claras possíveis, de modo a abranger as frequentes situações de conflito no ambiente organizacional. A educação é necessária para a consolidação da ética; o monitoramento é necessário para coibir os desvios éticos; e a aplicação de sistema de consequência constitui as infrações que devem ser penalizadas.

Tem-se, a seguir, a colocação de educadores renomados, a respeito da educação para a ética. Anísio Spínola Teixeira, por exemplo, um dos idealizadores da Universidade de Brasília, e reitor entre junho de 1963 e abril de 1964, revela que

uma sociedade móvel, cheia de canais distribuidores de todas as mudanças ocorridas em qualquer parte, deve tratar de fazer que seus membros sejam educados de modo a possuírem iniciativa individual e adaptabilidade. Se não fizerem assim, eles serão esmagados pelas mudanças em que se virem envolvidos e cujas as associações ou significações eles não percebem. (TEIXEIRA apud CAMPOS 2007, p. 119) 
Se os homens são capacitados para a obtenção da conduta ética e exercitam as orientações frequentemente, a gestão democrática é instalada no ambiente público. Teixeira (op.cit.:113) afirma também que "toda a educação ministrada por um grupo tende a socializar seus membros, mas a qualidade e o valor da socialização dependem dos hábitos e aspirações do grupo". Por essa razão, é necessário o exercício frequente da conduta ética, de modo a se tornar um hábito e influenciar as aspirações.

Alledi e Quelhas (2002:01) revelam que "a função de uma universidade é pesquisar, ampliar e disseminar o conhecimento", o que se pretende conceber com este estudo, de forma a promover os trabalhos educativos da Comissão de Ética na Universidade de Brasília, de modo que seu ambiente acadêmico seja um fator favorável para capacitar o seu quadro de pessoal. Essa concepção ratifica a importância da criação e manutenção de uma cultura ética na organização, ainda mais em se tratando de uma universidade, que tem as atribuições de pesquisar e disseminar o conhecimento, mesmo que um dos maiores desafios da administração universitária seja a de garantir os meios e recursos necessários para manter cursos de capacitação contínuos para o seu quadro de pessoal (BERNARDES, 2003). Nesse sentido, Amaral (2014:551) corrobora com essa ideia, ao afirmar que, "para que a administração pública brasileira seja, de fato, um dos fatores de riqueza e de vantagem competitiva no país, será imprescindível investir nos servidores".

A respeito da necessidade de criação de uma cultura ética organizacional, Passos (2010:70) coloca a importância de se trabalhar a formação ética em organizações:

Ajuda a enfrentar problemas, a resolvê-los e a evitar que outros ocorram, pois ela, além de orientar o caminho a ser seguido, também limita o espírito aventureiro e estimula a crítica e as ações coerentes e responsáveis. Portanto, faz-se necessário que seja uma prática constante e um compromisso de todas as pessoas que vivem a realidade da organização.

É necessário que haja a prática constante da ética, que deve ser reconhecida pelos dirigentes da organização, bem como implementada, uma vez que “à alta administração 
compete dar o exemplo, portando-se de forma correta, estimulando comportamentos éticos, promovendo e implantando um clima ético na organização. " (op.cit.:71).

Aguilar (1996:15), por sua vez, aconselha que "o custo da conduta antiética pode ir muito além das penalidades legais, notícias desfavoráveis na imprensa e prejuízo nas relações com os clientes. Muitas vezes, a consequência mais grave é o dilaceramento do espírito organizacional”. Para os órgãos públicos, além dos prejuízos citados por Aguilar, ocorre também um significativo dispêndio financeiro, assinalado por Léo da Silva Alves (2015) [Presidente do Centro Ibero-Americano de Administração e Direito], que afirma que “a realização de um processo administrativo disciplinar custa, em média, $\mathrm{R} \$ 25.023 .33$ aos cofres públicos”. Tal valor poderia ser economizado e direcionado para a implementação eficiente e educativa de instrumentos da gestão ética nas organizações.

TEIXEIRA apud CAMPOS(2007:39) acrescenta que “[...] se o olhar for constantemente alegrado por objetos harmoniosos, graciosos de forma e cor, desenvolve-se naturalmente o sentimento do bom gosto" e de responsabilidade, haja vista ser este um dos requisitos para que se tenha uma cultura ética. A este respeito, Vásquez registra que

o problema da essência do ato moral envia a outro problema importantíssimo: o da responsabilidade. É possível falar em comportamento moral somente quando o sujeito que assim se comporta é responsável pelos seus atos, mas isto, por sua vez envolve o pressuposto de que pôde fazer o que queria fazer, ou seja, de que pôde escolher entre duas ou mais alternativas e agir de acordo com a decisão tomada. $\mathrm{O}$ problema da liberdade da vontade, por isso é inseparável o da responsabilidade. (VÁSQUEZ, 1992:2,3)

A prática da boa moral é necessária, pois a sociedade está presenciando a destruição das relações interpessoais, que, por sua vez, estão desencadeando o aniquilamento do ambiente laboral e de outros ambientes em que o ser humano esteja inserido, como, por exemplo, a natureza; esquecendo-se que o homem também faz parte dela. Conforme afirma Passos (2010:28),

ao afirmarmos que o ato moral é exclusivo do ser humano, somos levados a admitir que a moral possui raízes nele, pois dele depende a decisão quanto ao tipo de comportamento a ser assumido. Contudo, como fizemos ver ao longo destas 
reflexões, os valores morais não são criados por acaso; eles servem a determinados fins. Assim, sua manutenção ou superação não são frutos da escolha livre do agente, mas da estrutura social, política e econômica da sociedade a que ele se ache vinculado.

Depreende-se desta citação, que a implementação de uma boa moral deve ser seguida de bastante esforço, para criar inclusive condições adequadas, para esta conscientização, haja vista a interferência que deverá ocorrer na consciência coletiva, provocando assim o efeito desejável e duradouro, mas não só isso. O trabalho deve ser contínuo e motivador, de modo a influenciar as aspirações dos indivíduos, posto que as pessoas tendem a participar efetivamente de algo se estiverem motivadas, conforme revela o estudo da motivação, em que Maslow (1954, apud SAMPAIO, 2009:8) afirma que "o homem é um animal desejante e raramente atinge um estado de completa satisfação exceto por um curto período de tempo. Assim que um desejo é satisfeito, outro explode e assume o seu lugar".

O ambiente não pode ser hostil, pois quanto mais complicadas forem as relações de trabalho, mais problemas a instituição terá, não só de ordem financeira, mas também do desenvolvimento de um trabalho bom e eficiente. Assim, "caso se esteja verdadeiramente interessado em promover o desenvolvimento do ser humano, especificamente daquele que trabalha em organizações, deve-se cultivar, além da técnica, a atenção e o afeto pelas pessoas" (BERGAMINI e BERALDO, 2010:38).

Paulo Freire fala de ética e democracia nas instituições de ensino:

Precisamos hoje no Brasil, talvez mais do que ontem, de uma prática educativa exemplarmente democrática. Precisamos de campanhas realizadas, por exemplo, através de estudos da democracia em escolas públicas, privadas, universidades, escolas técnicas, sindicatos. Campanhas que encharcassem a cidade de democracia. Semanas em que se apresentassem a história da democracia, em que se debatessem a relação entre democracia e ética, e classes populares e econômicas. Eleições, direitos e deveres que elas implicam. Inexperiência democrática brasileira. Democracia e tolerância. Gosto da liberdade e democracia; forças inconciliavelmente contraditórias, forças conciliavelmente diferentes; unidade na diversidade. (FREIRE, apud CAMPOS, 2007:39) [grifo nosso] 
Essa prática educativa democrática de Paulo Freire é registrada como a ação correta que o Estado deve ter para moralizar a administração pública. Campanhas e debates são instrumentos de conscientização, os quais devem ser adotados pelo gestor democrático. Segundo Chagas (2010:73), “a instrução sem educação e o desenvolvimento das qualidades profissionais sem a dimensão cívica podem produzir indivíduos ainda mais antidemocráticos que os sem estudo". Esta afirmação pode ser considerada como um alerta para a real necessidade de um programa educativo sobre ética no ambiente organizacional. Um dos princípios basilares do Estado Democrático de Direito deve ser a constante busca e aplicação de elevados padrões éticos que facilitem o exercício da cidadania.

Neste ínterim, Passos (2010:28) revela quais seriam as características necessárias para uma nova ordem moral: “em primeiro lugar, faz-se necessário respeitar a pluralidade dos valores, porque a liberdade só pode manifestar-se eficazmente quando existe igualdade de oportunidades”. Essa igualdade remete ao Estado democrático. O autor segue dizendo que

a liberdade é o cerne dessa nova ética. Entendida como a supressão de todo tipo de coação, interna e externa, e de toda repressão imposta pela lei ou pela necessidade. Em outras palavras, o ser humano torna-se livre quando consegue olhar a realidade de forma mais simples, mais alegre e menos séria. Quando ele consegue ultrapassar o modelo de trabalho alienado, centrado na seriedade e na falta de prazer. Livre da repressão e da exploração, representativas de uma sociedade comprometida apenas com a produtividade com o lucro desmedido e com o sucesso a qualquer preço. (PASSOS, 2010:28)

Mesmo que o sistema capitalista tenha forte influência no mundo atual, verifica-se

a real necessidade, não só por questões de boa convivência, como também de saúde, de que as pessoas possam primar pelas boas práticas, por comportamentos que demonstrem o respeito e que promovam a paz. Passos também afirma que

além das necessidades físicas, os indivíduos possuem as espirituais (amizade, prazer, cultura e descanso). O novo discurso filosófico (pós-modernidade) partilha desse ideal voltando para a vida prática e distanciando-se das fórmulas e saberes estabelecidos. É no bojo dessas possibilidades que essa nova moral, que pode ser identificada como emancipatória, se coloca. Essa ética pode ser assumida como a da justiça social, ao colocar em primeiro plano o bem, em detrimento da defesa da lei moral (PASSOS, 2010:29). 
Depreende-se que uma sociedade aspirante de um presente e futuro digno deve primar por essa transformação social, pautada na moral de bons costumes, honestidade, igualdade, solidariedade e amor (PASSOS, op.cit.). Assim, na ética de valores que agregam para a sociedade, boas atitudes a serem seguidas devem ser disseminadas. Passos revela outra questão importante para a construção de consciências éticas:

[...] não devemos lutar contra a individualidade e sim contra o individualismo. As qualidades individuais devem ser respeitadas e assumidas dentro da esfera pública, criando condições para que seus anseios e desejos possam ser realizados desde que não se transformem em egoísmo e individualismo. Situações que deixariam de reconhecer a existência do outro e passariam por cima de qualidades como tolerância, cooperação social e equidade (PASSOS, 2010:30).

Ética exige gestão participativa, diz Matos (2008) em que "sem se acreditar verdadeiramente nas potencialidades e na motivação humana, nada de grandioso pode ser construído, pois a força estará limitada pelo individualismo".

As Comissões de Ética têm como missão acrescentar valor à instituição, bem como de assegurar o conhecimento do que é um comportamento ético, de acordo com a legislação, por meio de uma educação preventiva e constante. "Não basta ter o marco regulatório. A implementação das normas de conduta tem exigências próprias" (CARNEIRO et al., 2002:21). Estas comissões são referenciais da supremacia da ética no ambiente de trabalho. Estes grupos viabilizam o aconselhamento de questionamentos éticos e tomam decisões relacionadas às situações que envolvam o comportamento de desvio ético de servidores.

As Comissões de Ética locais estão ligadas à Comissão de Ética da Presidência da República (CEP/PR), a qual funciona como órgão central e disseminador da ética nos órgãos públicos, mas não funciona como órgão recursal de decisões dos processos de desvio ético relacionados a tais órgãos, haja vista a autonomia das Comissões de Ética locais, como foi dito anteriormente neste estudo. O trabalho dessas comissões está voltado para os prestadores de serviços e servidores do quadro de pessoal (agentes públicos), excluindo, no campo das 
universidades públicas, a análise dos conflitos entre discentes. Entretanto, se um docente incorre em falta de ética para como seu aluno, este pode acionar a Comissão de Ética, ou seja, o discente poderá figurar como denunciante, mas na Comissão de Ética, nunca irá figurar como denunciado, posto a sua condição de não agente público.

O estabelecimento destas comissões revela aos funcionários que a ética é uma questão séria na instituição, e para que seja vista dessa forma é necessário que esteja acompanhada da eficiência, bem como da eficácia, princípios estes que foram propostos pelo Programa Nacional de Gestão Pública e Desburocratização - Gespública.

\subsection{Eficiência, Eficácia: Correlação Necessária como Um dos Fatores para a Implementação da Ética na Gestão Pública}

Este item objetiva, inicialmente, caracterizar os conceitos de eficiência e eficácia, uma vez que são vistos como fatores fundamentais à implementação da ética na gestão pública, especificamente neste caso, na instituição de ensino, Universidade de Brasília. O item tem por objetivo evidenciar que esses conceitos se fazem relevantes para a obtenção de respostas ao problema delimitado, uma vez que analisar a Comissão de Ética da Universidade de Brasília e a compreensão da dimensão como prática educativa impôs uma análise cuidadosa na investigação. O tópico apresenta também, a norma legal que institui o Sistema de Gestão da Ética do Poder Executivo Federal - o Decreto nº 6.029/2007 -, que promove e direciona as atividades das Comissões de Ética.

Acerca desses temas para o bom desempenho na gestão, outra estratégia de governo que tem sido implementada no alcance dessas práticas, como por exemplo, a criação 
do Programa Nacional de Gestão Pública e Desburocratização - Gespública, o qual foi instituído em 23 de fevereiro de 2005 pelo Decreto Federal n ${ }^{\circ} 5.378$, trazendo a proposta de implementação de práticas de excelência em gestão. Trata-se de um programa federal que visa alcançar toda a federação, e apresenta como um dos seus principais objetivos, a eficiência na prestação de serviços, além da eficácia na aplicação do dinheiro público (SILVA e FADUL, 2011).

Em relação à excelência em gestão, vale salientar que a exigência da excelência jamais poderá ser satisfeita, pois sempre é possível melhorar - o vocábulo excelência esconde-se sob o conceito de qualidade (MORAES, 2012). Assim, o conceito de qualidade “aparece sempre como melhoria, como progresso e não como pressão. Entretanto, esta noção de qualidade é uma utopia de perfeição que remete a um paraíso perdido" (MORAES, 2012:87-288). Depreende-se destas citações que as exigências por qualidade enquanto excelência será sempre algo utópico, haja vista as pessoas não estarem inseridas em um "mundo harmônico e sem contradições" (GAULEJAC, apud MORAES, 2012: 288). Entretanto, faz-se necessário levantar alternativas que se aproximem do ideal desejado, para obter-se um bom desempenho na gestão. Gaulejac acrescenta:

Hoje, a gestão é um modo de relação com o mundo e consigo mesmo que busca racionalizar e otimizar o tempo, o corpo, a mente, a subjetividade, as relações de modo a tornar a vida mais rentável, mais útil e competitiva na perspectiva de empregabilidade. O novo modelo empresarial de organização se impõe à sociedade, substituindo antigos padrões do exército e das fábricas. As forças produtivas já não estão no corpo, estão na psique. Já não se trata de uma empresa disciplinar, nos moldes descritos por Foucault, mas de um modelo gestionário flexível que pretende seduzir o corpo e a alma, envolver a psique e orientá-la para a capitalização das empresas. (GAULEJAC, 2007:110)

O modelo de gestão atual acompanha as mudanças da sociedade e relaciona o mundo com o indivíduo, em que o trabalhador passa a ser visto em sua totalidade com contribuições físicas e psicológicas para a sua Instituição. A partir desta concepção é que se faz necessária a implementação eficiente e eficaz de programas como o Gespública e o Sistema de Gestão da Ética do Poder Executivo Federal. 
Desse modo, para que o Gespública alcance a eficiência desejada em seus resultados é necessário que o Governo Federal preste o suporte necessário para melhorar a eficiência da Administração Pública. Uma das ações do governo está voltada para um trabalho de conscientização da ética no serviço público. Cabe salientar que por mais que tais ações de promoção da ética na rede pública e o programa Gespública estejam desvinculados quanto à sua origem, ambos se encontram vinculados pelo alcance de seus objetivos, uma vez que o trabalho de um facilita o de outro e vice-versa.

Assim, como houve a introdução do princípio da eficiência na legislação federal, houve também a implementação de outras ferramentas para subsidiar a eficiência nestes órgãos, como dito anteriormente. Porém, é importante salientar que as Comissões de Ética locais, instituídas pelo Decreto $\mathrm{n}^{\circ} 6.029$, de $1^{\text {o }}$ de fevereiro de 2007, devem proferir decisões sobre a conduta ética no âmbito do Executivo Federal.

Art. 16. As Comissões de Ética não poderão excursar-se de proferir decisão sobre matéria de sua competência, alegando omissão do Código de Conduta da Alta Administração Federal, do Código de Ética Profissional do Servidor Público Civil do Poder Executivo Federal ou do Código de Ética do órgão ou entidade que, se existente, será suprida pela analogia e invocação aos princípios da legalidade, impessoalidade, moralidade, publicidade e eficiência (BRASIL, 2007). [grifo nosso]

Depreendesse deste artigo, que até mesmo em deliberações dessas Comissões, o elemento eficiência deverá se fazer presente. A resolução no 10 de 29 de setembro de 2008 , Cap. 1, Das Competências e Atribuições, Art. $2^{\circ}$ inciso VI, diz respeito a competências dessas comissões de ética, a saber: orientar e aconselhar sobre a conduta do servidor, inclusive no relacionamento com o cidadão e no resguardo do patrimônio público.

Deste normativo, deduz-se que a ética deve permear as ações dos servidores, não só em relação aos cidadãos, mas também para com o patrimônio público que deve ser tratado também sobre a ótica da eficiência e melhor custo e benefício para a administração pública.

De modo a esclarecer o significado de eficiência e eficácia, verificasse a seguinte explicação, "a eficiência é um conceito utilizado por diferentes ciências (ciências econômicas, 
pela sociologia, pelas ciências da gestão e da administração), portanto, um conceito polissêmico" (VIANA, 2010:301). A eficiência refere-se, ainda, à relação entre meios e fins e a eficácia designa a relação entre os objetivos e fins. No que diz respeito à eficiência de desempenho, Bergamini e Beraldo revelam ser

o produto do grau de adequação e qualidade com que uma pessoa realiza determinada atividade ou tarefa. O desempenho eficiente é, portanto, aquele que atende em alto grau às manifestações dos traços de personalidade, utilizados adequadamente na realização de uma tarefa. (BERGAMINI e BERALDO, 2010:37)

Pode-se inferir que um desempenho eficiente é aquele que está calcado em ações bem-feitas. Então, pode-se fazer alguma distinção entre estes dois "es" (eficiência e eficácia) na Gestão Pública. Segundo Bilhin (2008:399), “a eficiência preocupa-se com os meios, os procedimentos e os métodos utilizados, que precisam ser planejados e organizados, a fim de concorrerem para a otimização dos recursos disponíveis, não sendo dada relevância aos fins".

A afirmação indica que para alcançar a eficiência é necessário se preocupar em fazer as coisas de forma certa, e é aí que entra a ética do servidor público; enquanto a eficácia se preocupa em fazer o que satisfaz as necessidades da organização (BILHIN, op.cit.).

O artigo 37 da Constituição Federal/88 diz que a Administração pública direta e indireta de qualquer dos poderes da União dos Estados, do Distrito Federal e dos Municípios, obedecerá aos princípios de legalidade, impessoalidade, moralidade, publicidade e eficiência. O Decreto-Lei no 200/1967 visa à implementação da eficiência nas organizações públicas, no que se refere à prestação de serviços.

Do exposto, verifica-se que há necessidade de se fazer Gestão Pública com mais eficiência, e assim, seguir com o desenvolvimento de que o Brasil precisa, de modo a ir deixando, aos poucos, os pontos negativos do modelo burocrático, implantado pelo Presidente Getúlio Vargas desde a década de 30. Entretanto, para que a eficiência (1E dos 2Es apresentados neste estudo) tenha efeito na Gestão Pública, é imprescindível que os atores envolvidos na gestão estejam comprometidos com este conceito e que a eficiência seja 
considerada critério de desempenho, de modo a se verificar o nível de utilização de recursos frente aos seus objetivos. Sano e Montenegro Filho (2013) relatam que a eficiência faz parte do discurso de melhoria da gestão pública e é, inclusive, um princípio constitucional que rege a administração pública.

A atenção a este princípio constitucional na prática laboral constitui a adoção de uma postura ética do servidor público por agir de acordo com o que preconiza a lei maior. Entretanto, para que ocorra este desenvolvimento social na Gestão Pública é importante que haja o estabelecimento de métodos que visem convencer e capacitar os envolvidos, como revelam Sano e Montenegro Filho (op.cit.). Os mesmos autores também destacam que a busca pela eficiência implica uma melhor utilização dos recursos, resultando no combate à corrupção. Diante dessa afirmação, o Decreto nº 1.171, de 22 de junho de 1994, Capítulo I, Seção I, Das Regras Deontológicas, reza o seguinte:

VIII - Toda pessoa tem direito à verdade. O servidor não pode omiti-la ou falseá-la, ainda que contrária aos interesses da própria pessoa interessada ou da Administração Pública. Nenhum Estado pode crescer ou estabilizar-se sobre o poder corruptivo do hábito do erro, da opressão ou da mentira, que sempre aniquilam até mesmo a dignidade humana quanto mais a de uma Nação (BRASIL, 1994) [grifo nosso]

Em suma, o serviço público, qualquer que seja ele, deve pautar por princípios básicos, capazes de doar-lhe substancialidade e eficácia, inclusive, com inserção de valores em infraestrutura (CARMO, 2004:9). No dia do servidor público, a presidente Dilma Rousself pediu ética e eficiência aos servidores públicos, conforme relatado pela colunista, Monteiro, no Jornal Estadão de São Paulo:

Em mensagem alusiva ao dia do servidor público, comemorado neste domingo (28), a presidente Dilma Rousseff pediu "ética", "eficiência", "empenho" e "comprometimento" aos funcionários. "Persistir no atendimento das justas e legítimas demandas de todos brasileiros e brasileiras exige uma gestão pública de excelência, pautada pela ética e pela eficiência. Exige servidores públicos empenhados, competentes e comprometidos", comentou a presidente..." (MONTEIRO, 2012). [grifo nosso] 
A implementação de um Sistema de Gestão da Ética do Poder Executivo Federal contribui para o alcance da eficiência na gestão. A ética deve ser introduzida pelo estabelecimento de métodos que visem convencer e capacitar os envolvidos, e assim ser interiorizada na conduta dos servidores públicos, os quais estarão mais bem preparados para prestar um serviço público que vise ao alcance do melhor custo e benefício (eficiência) para a Administração Pública, por meio de decisões mais acertadas e pautadas em princípios éticos. O processo decisório pode ser dimensionado pela ética, conforme expõe-se no próximo item.

As Comissões de Ética locais devem observar que a Comissão de Ética Pública$\mathrm{CEP}$, foi criada em um momento pós "cenário de insatisfação da sociedade civil em relação às imperfeições dos sistemas políticos, especificamente quanto ao comportamento das autoridades. Existiu, nesse limiar, uma fase nebulosa quanto aos conflitos de interesse, gerada pela inerente dificuldade da separação das esferas público e privada" (BRASIL, 2015). Essa lembrança constitui uma necessidade de coibir os desvios éticos, bem como melhorar a imagem do serviço público no Poder Executivo Federal, assim como a criação de uma instância que faça, além da prevenção, a orientação contra práticas de desvio éticos. Lembrase também que, dentre os fatores de motivação da Comissão de Ética da Presidência da República, tem-se às experiências internacionais que:

refletidas nas convenções multilaterais contra a corrupção surgidas nos âmbitos da Organização dos Estados Americanos - OEA (1996), da Organização para a Cooperação e o Desenvolvimento Econômico - OCDE (1997), aliada às necessidades internas do Estado brasileiro, tornou-se imprescindível a criação da Comissão (BRASIL, 2015).

O sítio eletrônico da CEP/PR, na seção histórico, revela que as experiências internacionais se tornaram espelho para a determinação dos padrões éticos no Código de Ética então criado, de forma a assegurar ou restabelecer a confiança da sociedade nas instituições governamentais (BRASIL,2015). Assim, após a criação da CEP, as comissões de ética locais foram instituídas em cumprimento ao disposto no Decreto no 6.029 /2007 ao dizer: 
Art. $8^{\circ}$ Compete às instâncias superiores dos órgãos e entidades do Poder Executivo Federal, abrangendo a administração direta e indireta: II - constituir Comissão de Ética; III - garantir os recursos humanos, materiais e financeiros para que a Comissão cumpra com suas atribuições; e IV-atender com prioridade às solicitações da CEP.

A constituição dessas Comissões integra a Rede de Ética do Poder Executivo Federal na intenção de promover a ética na Administração Pública (DECRETO 6.029/2007), e que, junto ao Gespública, propende ao alcance da promoção da eficiência na realização das atividades administrativas com a aspiração de que tais ações sejam eficazes.

\title{
2.6 O Processo Decisório nas Organizações e a Sua Dimensão Ética ${ }^{2}$
}

O capítulo trata de forma breve sobre o processo decisório, posto que a ênfase se dá sobre a ética no processo decisório. A ideia é transmitir essa necessária simbiose da relação entre ética e processo decisório organizacional, uma vez que se evidencia que há uma interdependência entre os dois conceitos para a melhor e mais acertada tomada de decisão daqueles que estão inseridos em um contexto organizacional.

A relação entre ética e processo decisório organizacional se faz necessária, uma vez evidenciada a interdependência para que sejam acertadas a tomada de decisão. Nesse sentido, Freitas (2006:105) enfatiza que

\begin{abstract}
não existe moral nem ética de empresa. O que existe é ética de pessoas e são elas que podem alterar o comportamento chamado organizacional. É claro que o comportamento não é um mero decalque do individual, mas uma gestão exercida por pessoas que valorizam um comportamento mais humano, mais responsável e mais honesto e saudável. Tal comportamento tenderá a produzir decisões em que os aspectos éticos serão considerados relevantes.
\end{abstract}

\footnotetext{
${ }^{2}$ Este subitem integra o artigo produzido com o mesmo nome que foi publicado na Revista Eletrônica Gestão \& Saúde (2015), sob a denominação de 'O processo decisório nas Organizações e a sua Dimensão Ética”.
} 
Para que haja sucesso em processos decisórios, é necessário que haja a valorização da ética nas organizações, seja através da constituição de códigos de ética e palestras motivacionais, seja no trato diário para com o outro. Todos tendem a ganhar com a instituição da ética: trabalhadores, contribuintes e gestores, assim como a imagem geral da organização.

É necessário contextualizar a importância da Ética em meio ao processo decisório organizacional, visando alcançar o aprimoramento de comportamentos comunicativos, os quais, por sua vez, influenciam nos processos decisórios de ambientes organizacionais. Afinal, como dito anteriormente, "não basta ter o marco regulatório. A implementação das normas de conduta tem exigências próprias” (CARNEIRO et al., 2002:21). Além do que,

advogam-se hoje, ante os clamorosos insucessos decorrentes da inércia burocrática, mudanças radicais. Considera-se preciso quebrar rapidamente essas estruturas verticalizadas e caducas. Não é possível conviver impunemente com um processo decisório emperrado ante os reclames de um público cada vez mais exigente (MATOS, 2008:62).

O Processo Decisório Organizacional será discutido aqui em sua questão conceitual, bem como nos aspectos relevantes para a tomada de decisões em ambientes organizacionais. Segundo Braga (1987:38), “o processo decisório é definido como o processo de pensamento e ação que culminará com uma escolha, a qual consiste em selecionar dentre cursos alternativos de ação ou mesmo aceitar ou rejeitar uma ação específica.

Sob esse prima, tanto o pensamento quanto a ação norteiam o processo decisório, especificando os problemas e as soluções que culminarão em uma tomada de decisão. Esta tomada de decisão pode ocorrer de forma programada (rotineira) ou não (estas são pouco estruturadas e de natureza complexa). "A maior parte das decisões nas organizações recai nas categorias de decisões programadas e não programadas" (SIMON, 1965 apud BRAGA, 1987:48). Este último tipo, as não programadas, por não existir um método predeterminado para lidar com elas ou executá-las, evidenciam as fragilidades do processo decisório. Por isso, 
demanda-se uma maior sustentação ou formação nesse processo decisório, sendo a ética parte fundamental desta sustentação de decisão (SIMON, 1965 apud BRAGA, 1987).

Simon (op.cit.:38) afirma que o processo decisório em organizações é uma situação complexa que envolve muitas pessoas, na qual o sucesso a ser alcançado por alguns pode significar a derrota de outros. Essa complexidade revela-se, por exemplo, nos vários interesses pessoais de indivíduos que compõem as estruturas organizacionais. Para a resolução desses conflitos, é necessário que haja mais decisões programadas com mais objetividade e imparcialidade, Simon (op.cit.). Segundo Braga,

o processo decisório são os procedimentos de definição de problemas, avaliação de alternativas e escolha de uma diretriz de ações e/ou soluções. Diferentes tipos de decisão, ao que parece, requerem tipos diversos de comportamentos de definição e de solução de problemas (BRAGA, 1987:45).

Do exposto, depreende-se que é necessário o servidor estar preparado tecnicamente e com formação suficiente para atuar adstrito à ética em seus processos decisórios, tanto em uma decisão programada, bem como, e principalmente, em decisões não programadas. Ou seja, deseja-se correlacionar o processo decisório com a ética, vez que, para o que se pretende, é indispensável confrontar o processo decisório com o que reza a ética.

Para fazer compreender a relação entre ética e processo decisório e o quanto ele pode ser prejudicado sem ela, clama-se pelos ensinamentos de Hebert Simon, que apresenta como postulado fundamental a limitação da racionalidade humana, revelada na necessidade de o conhecimento ser completo e antecipado das consequências de uma determinada decisão. Essas consequências pertencem ao futuro, e a imaginação deve atribuir valores a elas. A racionalidade humana estará na identificação das opções alternativas, que serão definidas pelo possível comportamento alternativo. Apenas uma fração de todas essas possíveis alternativas é levada em consideração (SIMON, 1965, apud GOMES 1999). É esta que deverá estar repleta de ética, pois é ela que se efetivará na realidade, ou seja, há uma premente necessidade de suprir a limitação da racionalidade humana, de modo que o processo decisório de uma 
organização deva estar permeado por condutas éticas, que são postuladas pelo estabelecimento de valores.

Para a tomada de decisões objetivamente racionais, em que Simon descreve como aquela que representa de fato o comportamento correto para maximizar certos valores numa dada situação, é dado pela ética. "O processo decisório deve partir de alguma premissa ética considerada pré-existente. Essa premissa ética descreve o objetivo da organização em pauta" (SIMON, 1979, apud GOMES, 1999:52). A questão ética está sendo suscitada neste trabalho "por viabilizar a introdução de valores morais nas decisões em sociedade, onde a competitividade atinge níveis de selvageria que merece a atenção dos teóricos" (GOMES, 1999:23).

Nessa visão, pode-se constatar a complexidade das organizações na tomada de decisões, por isso, a ética se faz necessária, uma vez que traz à tona os valores fundamentais que facilitam a concretização dos objetivos organizacionais e a necessidade de ordem e estabilidade organizacional. Zylberstztajn afirma que

o comportamento ético representa um valor de sociedade moderna; no entanto existem falhas no comportamento ético dos indivíduos, das organizações e das sociedades. Todos os desvios possíveis e conhecidos do comportamento humano podem estar presentes nas organizações, sejam elas empresas, sejam organizações não governamentais, seja o próprio Estado (ZYLBERSTZTAJN 2002, apud GOMES, 1999:39).

Em relação ao comportamento ético, Vasquez revela ser a ética

\begin{abstract}
a teoria ou ciência do comportamento moral dos homens em sociedade. Ou seja, é a ciência de uma forma específica de comportamento humano, assim, o ético transforma-se [...] numa espécie de legislador do comportamento moral dos indivíduos ou da comunidade [...]. Desta maneira temos, pois, de um lado, atos e formas de comportamento dos homens em face de determinados problemas, que chamamos morais, e, do outro lado, juízos que aprovam ou desaprovam moralmente os mesmos atos. Mas, por sua vez, tanto os atos quanto os juízos morais pressupõem certas normas que apontam o que se deve fazer (VÁSQUEZ, 1992:1, 3, 5).
\end{abstract}

Por isso, tem-se a necessidade da introdução do estudo da ética nas instituições, “não necessariamente movidas por atitudes benignas e cooperativas, mas para manter o seu valor de reputação, as organizações tendem a preocupar-se crescentemente com o tema" 
(ZYLBERSZTAJN, 2002, apud GOMES, 1999:140). A introdução da ética nas organizações, segundo Passos,

possibilita que os indivíduos tenham alegria com o que fazem, além de fortalecer o compromisso com a organização, renovando e colocando em prática o poder criativo e produtivo que possuam além de solidariedade, estimulando, enfim, as condições necessárias à manutenção da organização (PASSOS, 2010:66).

Essa introdução da ética nas organizações deverá se apoiar nas lideranças, para que haja a necessária credibilidade, pois, conforme revela Matos (2005:4,5),

se as lideranças não confirmarem a lógica da atitude, a lógica formal não garante a necessária credibilidade. Ser ético, como atitude na gestão, significa, em essência: reconhecer o desempenho funcional, propiciar participação nos resultados, estimular o compromisso social e favorecer a educação continuada. [grifo nosso]

Em relação ao papel das lideranças na gestão da ética "a gestão ética e o desempenho social das organizações pode efetivamente constituir, ainda que parcialmente, um reflexo da maturidade moral dos seus dirigentes" (TREVIÑO e BROWN, 2005:112), o que corrobora com CARROL (apud Meira, 2010:15) quando diz que "enquanto os dirigentes não abraçarem completamente os conceitos da gerência moral, a transformação cultural nas empresas, que é essencial para o florescimento da gestão ética, não irá acontecer.”

Verifica-se a forte influência que os dirigentes têm sobre a cultura nas empresas, com isso, “os empregados devem ser 'levados' para a ética a partir do topo, da mesma forma que devem ser levados em matéria de qualidade, competitividade e a um conjunto de outros comportamentos esperados” (TREVIÑO e BROWN, 2005:74).

A reflexão ética é um instrumento fundamental que ajuda no processo decisório de organizações. Nesse sentido, Passos afirma que

o primeiro passo para superar a situação é a descoberta de valor de reflexão ética como orientação segura para que o indivíduo possa tomar melhores decisões, errar menos ou até mesmo, prevenir os erros. Por exemplo, nas relações profissionais, ela pode ser garantia de respeito a direitos básicos dos empregados, tais como: receber informações, poder reunir-se ou falar livremente (PASSOS, 2010:100). 
Nessa visão, a instituição da ética nas organizações possibilita a confiança de seus integrantes na participação do processo decisório organizacional, pelo fato de a organização com sua conduta ética admitir as opiniões ou sugestões sem críticas ou retaliações, mesmo que essas participações não venham a ser consideradas no processo. A organização que adere aos princípios éticos em sua estrutura respeita as participações de seus integrantes, garantindo processos decisórios mais justos e igualitários. Além disso, ser ético no comportamento de gestor com sua equipe significa: "delegar, delegar e delegar - a delegação, além de instrumento eficaz de gestão, implica dignificação do homem, pelo exercício do poder decisório" (MATOS, 2008:78).

Ao elaborar o processo decisório, em que muitas vezes, são poucos os envolvidos dentro da estrutura organizacional, é primordial atentar para a contribuição de todos os envolvidos no processo. A abertura para essas participações demonstra uma postura ética das organizações com seus associados, mesmo que tais sugestões não venham a ser consideradas para a tomada de decisão. Esta atitude ética se torna frutífera no interior das organizações por disseminar a democracia e o bom convívio entre os indivíduos com o órgão para qual trabalham.

Há complexidade na elaboração de um processo decisório, posto que as organizações são compostas por pessoas, as quais possuem interesses individuais e nem sempre estão imbuídos de intenção ética, o que favorece o caos organizacional. Logo, para que as decisões sejam tomadas de uma forma mais racional, é necessário que essas decisões sejam constituídas de premissas éticas na direção dos objetivos da organização, bem como outros fatores, como por exemplo, o contexto, o tempo, a objetividade, a imparcialidade, a boa comunicação e a política organizacional ética. Todos estes fatores afetam significativamente o processo decisório organizacional. Em relação à boa comunicação, Cardoso (2006:1132, 1133)) revela que 
cada vez mais, torna-se claro como os processos de comunicação contribuem para desenvolver formas de inter-relação mais participativas e, portanto, mais comprometidas, dando maior flexibilidade às organizações como base de sua permanente transformação e facilitando sua interação social de modo responsável para conjugar seus interesses com as condições culturais, econômicas e políticas nas quais se movem.

O fator comunicação institucional é um grande aliado para a gestão ética organizacional, haja vista poder ser utilizado como um instrumento de transparência, além de proporcionar maior integração dos trabalhadores em prol da organização, bem como por ser um processo decisório mais compartilhado em prol dos objetivos organizacionais.

\subsection{Trabalho Educativo por Meio da Teoria Andragógica}

O sistema de educação para adultos não se utiliza da teoria pedagógica, mas sim da teoria andragógica. Por se tratar de ensino para servidores públicos inseridos na Universidade de Brasília, este tópico explicita como se dá essa teoria em sua prática, evidenciando a importância da utilização de tais instrumentos de gestão ética dispostos pela teoria andragógica. A teoria é forma de alcançar um grande número de servidores, suprindo a lacuna de suas capacitações, no intuito de melhor explicitar e inserir práticas educativas-éticas no dia a dia dos funcionários públicos.

Assim, por meio do procedimento educativo da Andragogia e os instrumentos de gestão ética, busca-se desenvolver um trabalho educativo, contínuo, pela Comissão de Ética com os agentes públicos da UnB. Deve-se partir da premissa de que se estará desenvolvendo atividades educativas para adultos, logo, será necessário recorrer a uma teoria que proponha "métodos que explorem, principalmente a experiência do aprendiz" (KNOWLES 1978, apud: VOGT, 2007:43), facilitando, assim, o aprendizado desse público específico. 
O estudo parte do conceito da Teoria Andragógica, em que o desenvolvimento de seu conceito sobre o processo de aprendizagem de adultos se difundiu ao longo do século passado, tanto nos Estados Unidos quanto na Europa, e fundamentada como tal teria, posteriormente, por Knowles 1980, apud: VOGT, 2OO7:40).

Em relação à etimologia do vocábulo andragogia, é a junção do prefixo anner ou andrós, que significa adulto ou homem, ao sufixo agogos, que significa guia. Vogt cita Knowles(1980) na definição de Andragogia, afirmando que ela foi conceituada

[...] como a arte e a ciência de ajudar os adultos a aprenderem, em contraste com a pedagogia que é a arte e a ciência de ensinar as crianças, posteriormente, admitiu que a andragogia é simplesmente outro modelo de princípios sobre a aprendizagem, que pode ser usado em paralelo com os princípios do modelo pedagógico (KNOWLES, 1980 apud VOGT, 2007:40).

Vogt (op.cit.:26) afirma que o objetivo principal da educação de adultos continua o mesmo, ou seja, "permitir ao indivíduo uma integração a mais plena possível, nas circunstâncias da vida, ou seja, impulsionar o adulto para o autodesenvolvimento e, assim, gerar um potencial capaz de influenciar nas desigualdades, fruto da rápida evolução da sociedade". É certo que a capacitação pode influenciar nas desigualdades, vez que, para o que se pretende coibir os desvios éticos que influenciam o comportamento individual e social.

Adultos podem adquirir conhecimento em seu ambiente societário, pelas experiências diárias vivenciadas e no ambiente educativo formal. Neste último, identifica-se como educação de adultos quando há um programa educativo, sistemático e planejado, dedicado às pessoas adultas (VOGT, 2007:30). Quanto aos postulados básicos da andragogia, Vogt revela que:

enquanto teoria ou sistema de ideias, de conceitos e de aproximações com a aprendizagem do adulto, foi introduzida e muito difundida nos Estados Unidos, por Malcolm Knowles, ao longo da segunda metade do século passado. Indiscutivelmente, seus postulados constituem uma importante referência sobre o assunto, de tal forma que, para muitos, o termo andragogia e o nome Knowles tornaram-se intrinsecamente ligados (VOGT, 2007:36). 
Nessa vertente da difusão, com métodos e premissas próprias de educação para adultos, haja vista as distinções existentes do ponto de vista da aplicabilidade em relação à educação voltada para as crianças, que se faz necessária a aplicação da andragogia na educação de indivíduos amadurecidos, conforme os princípios detalhados por Vogt (op.cit::36) Pode-se dizer, partir dos fundamentos de Knowles(1980), em relação a esses indivíduos, que

a) seu autoconceito move-se de um ser de uma personalidade dependente para um autodirigido;

b) seu reservatório de experiência se acumula e se transforma em um recurso crescente para aprender;

c) sua prontidão a aprender torna-se orientada, cada vez mais, às tarefas de desenvolvimento de seus papéis sociais;

d) sua perspectiva de tempo muda de uma ação de procrastinação do conhecimento à imediata aplicação; já sua orientação para a aprendizagem deslocase de uma aprendizagem centrada nas disciplinas a uma focada no problema, o que situa o modelo de ensino orientado na resolução de situação- problema, ou em metas como educação em saúde, capacitação profissional, entre outras;

e) motivação e aprender, quinta premissa que foi adicionada mais tarde e que segundo Knowles (1980) é intrínseca ao indivíduo amadurecido.

Pode-se depreender dos princípios relatados, que a educação promove a auto direção; o conhecimento estará constantemente sendo agregado e constituirá valor; a capacitação será bem aproveitada em papéis sociais; o conhecimento se transformará em ação orientada para a resolução de problemas no seu trato diário com acontecimentos advindos da vida; e, por fim, quando o indivíduo estiver motivado, o processo de aprendizagem se tornará uma resultante.

A educação deveria ser um processo contínuo ao longo da vida e deveria ter, como objetivo, a autonomia no processo de aprendizagem (VOGT, 2007:1), mas, enquanto isso não ocorre, melhor voltar para a orientação que se faz necessária. Vogt, informa, ainda, que as características de aprendizagem de adultos devem ser exploradas com base em abordagens e métodos apropriados. Para Knowles (1978, apud VOGT, op.cit.:43) a dinâmica metodológica, no ensino de adultos, tende a se mover nos métodos tradicionais a favor dos métodos que exploram, principalmente, a experiência do aprendiz, em cenários educativos, 
tais como: grupo de discussão, jogo de papéis, workshops, e várias combinações de métodos interativos. Inclusive, as palestras, na maioria das vezes, são mais simples de preparar, posto que há um baixo investimento em relação a outras formações (GALINDO e INFORSATO, 2008) Acerca dessas ações de treinamento, Borges-Andrade et al., revelam que

as ações de treinamento, desenvolvimento e qualificação do trabalhador ocupam um dos papeis centrais no conjunto de práticas, que denominamos gestão de pessoas, em contexto organizacional. Seus impactos, por sua vez, são fundamentais (...) para o ajuste indivíduo - trabalho que se traduz em diferenças de desempenho individuais e coletivos (BORGES-ANDRADE et al., 2006:23) [grifo nosso]

Logo, se essas ações são fundamentais, devem ser priorizadas em uma organização, haja vista os ganhos provenientes com tais atos, tanto na esfera individual quanto na organizacional.

Vogt (2007) revela três princípios adicionais sobre o ensino - aprendizagem de adultos, a partir da interação face a face entre o professor e seus alunos. São eles:

a) adultos podem aprender: premissa central da andragogia. Estudos contemporâneos sobre a aprendizagem do indivíduo amadurecido advertem que a aptidão inata de instruir-se continua inalterada ao longo da existência, apenas ocorre um decaimento a celeridade de aprender, entretanto, não na disposição intelectual. Tal decaimento pode ser minimizado pelo hábito em estudar;

b) a aprendizagem é um processo interno: ao longo do tempo, acreditava-se que o processo de aprendizagem era externo, haja vista o conteúdo assimilado partir do professor e a qualidade de recursos didáticos, o aluno seria um acumulador destas informações, porém Vogt (2007) revela o desenvolvimento de pesquisas sobre o que realmente acontece na aprendizagem. Embora não haja precisão na definição do que realmente ocorre, há o consenso de que um processo interno controlado pelo sujeito, que inclui a função intelectual, emocional, e psicológica influenciam neste processo. Afirma também, que a aprendizagem é descrita, psicologicamente, como um processo do encontro entre necessidade e meta de esforço dos estudantes;

c) existem condições superiores de aprendizagem e princípios de ensino: o conhecimento acumulado sobre o processo de aprendizagem do adulto indica que certas condições de aprendizagem são mais favoráveis ao crescimento e ao desenvolvimento que outras (VOGT, 2007:50).

Knowles 1978, apud VOGT(2007) apresenta um resumo de um projeto de ensino no modelo pedagógico e no andragógico, conforme demonstrado no Quadro 1. 
Quadro 1. Comparação entre a pesquisa de ensino pedagógico tradicional e andragógico

\begin{tabular}{|c|c|c|}
\hline & \multicolumn{2}{|c|}{ PROJETOS } \\
\hline & Pedagógico tradicional & Projeto andragógico \\
\hline Clima & $\begin{array}{l}\text { Orientado na autoridade } \\
\text { Formal } \\
\text { Competitivo }\end{array}$ & $\begin{array}{c}\text { De mutualidade } \\
\text { De respeito } \\
\text { Colaborativo } \\
\text { Informal }\end{array}$ \\
\hline Planejamento & Pelo professor & Mecanismo para planejamento mútuo \\
\hline $\begin{array}{l}\text { Diagnóstico de } \\
\text { necessidades }\end{array}$ & Pelo professor & Autodiagnóstico mútuo \\
\hline $\begin{array}{c}\text { Formulação de } \\
\text { objetivos }\end{array}$ & Pelo professor & Negociação mútua \\
\hline Plano/projeto & $\begin{array}{l}\text { Lógica da importância de conteúdo } \\
\text { Unidades por conteúdo }\end{array}$ & $\begin{array}{l}\text { Sequenciado de acordo com a prontidão } \\
\text { Unidades de problema }\end{array}$ \\
\hline Atividades & Técnicas de transmissão & Técnicas experimentais (questionamento) \\
\hline Avaliação & Pelo professor & $\begin{array}{l}\text { Rediagnosticar as necessidades } \\
\text { mutuamente. } \\
\text { Avaliação mútua do programa }\end{array}$ \\
\hline
\end{tabular}

Fonte: Knowles, 1978.

Pode-se inferir do Quadro 1, que o processo de ensino-aprendizagem em adultos ocorre com a participação desses indivíduos, uma vez que ser necessário levar-se em consideração o processo interno de aprendizagem citado anteriormente, além do préconhecimento de cada pessoa, como contribuição importante para a facilitação de entendimento do conteúdo repassado.

Ainda sobre a importância de um trabalho educativo sobre a ética, Bittar (2010) afirma que a discussão ética está entrelaçada à discussão educacional. Bittar(2010) justifica que isso ocorre, porque é impossível dissociar, ao fim do processo de formação de uma pessoa, ou grupo, a questão educacional do conjunto de predicados éticos que reúne(m). $\mathrm{O}$ autor segue seu relato fundamentando que

de fato, a educação é o implemento da formação não só intelectual, mas moral dos indivíduos. A partir do conhecimento, que de fato é de se reconhecer infinito e inexaurível, daí a consciência de que ars longa, vita brevis, se abrem múltiplas possibilidades de escolha, se descortinam múltiplas opções, profissionalizantes ou não. É a abundância de informações, qualitativamente gerenciadas que gera a liberdade de escolha. Em contrapartida, a escassez de informações engendra a falta de consciência crítica e, por consequência, a fácil manipulação do indivíduo. A ignorância na base de muitos erros (BITTAR, 2010:133). 
Sem o conhecimento do que seriam atitudes éticas desejáveis, não há que se falar em modos inadequados e em punições, haja vista o nosso ordenamento jurídico ser democrático. É preciso educar para então conscientizar, e assim afastar a ignorância que motiva os erros. O estudo, em si, não positiva a ação; é necessário que haja a conscientização e a prática. Nesse sentido, Bittar (2010: 31, 32) relata que

a ética como prática consiste na atuação concreta e conjugada da vontade e da razão, de cuja interação se extraem resultados que se corporificam por diversas formas. Se as ações humanas são dotadas de intencionalidade e finalidade, releva-se sobretudo a aferição prática da concordância entre atos exteriores e intenções. A realização mecânica de atos exteriores pelo homem deve estar em pertinente afinidade com a atitude interna, de modo que, da consciência à ação, exista uma pequena diferença de consumação. No fundo, a ação externa, modificativa do mundo (ação discursiva, ação profissional, ação política...), nada mais é que a ultimação de um programa intencional preexistente à própria ação; o programa ético é o correspondente guia da ação moral.

Verifica-se que a prática ética deve buscar conscientizações, ação interna, derivadas do estudo da ética e ações externas (consciência que motiva a ação), ou seja, atitudes dirigidas pela razão que se sobrepõem aos impulsos de ordem emocional. Diante do exposto pela teoria andragógica, quanto a ferramentas educacionais que podem ser aplicadas ao público adulto e diante do levantamento dos instrumentos de gestão da ética realizado neste estudo, verifica-se que há sinergia entre eles. Assim, concorda-se com Mendes, quando afirma que

a perspectiva sistêmica adotada assume que a efetividade da gestão da ética depende mais da sinergia entre os instrumentos que dos efeitos produzidos por cada um. Assim, a combinação entre as diferentes medidas, produzem efeito significativo, em que o conjunto dos efeitos é muito maior que a soma dos efeitos de cada instrumento (MENDES, 2014:101).

Várias são as ferramentas que poderão ser utilizadas e que provocarão um impacto maior juntas do que se forem aplicadas isoladamente, o que corrobora com a fala de Mendes (op.cit.:101) ao citar que "a combinação entre as diferentes medidas produz efeito significativo, em que o conjunto dos efeitos é muito maior do que a soma dos efeitos de cada instrumento". A mesma autora afirma que 
[...] os resultados desta pesquisa demonstram que a função educacional estabelecida como prioritária não atingiu o desenvolvimento necessário para promover a formação para a ética em todos os níveis hierárquicos da administração pública. Apenas o grupo de servidores que trabalha nas Comissões está sendo capacitado de forma sistemática (MENDES, 2014:232).

Diante do exposto, e conforme já dito, o interesse em trabalhar os instrumentos de gestão ética, em uma perspectiva andragógica, busca suprir esta lacuna, capacitando o maior número possível de servidores, sistematicamente. Propõe-se, por meio do procedimento educativo da Andragogia e dos instrumentos de gestão ética, apontados pelos teóricos, nesta pesquisa, uma construção de conscientização ética, de modo a colaborar para um ambiente laboral mais ético e democrático dentro da UnB, além de acrescentar para a área da administração mais estudos neste campo.

Para maiores esclarecimentos sobre os instrumentos de Gestão da Ética, que foram levantados nesse estudo, verificou-se também o documento da OCDE - Towards a sound integrity framework: instruments, processes, structures and conditions for implementation OECD - Public Governance Committee, 2009, através dos relatos de Mendes (2014), em que a autora revela o significado da palavra integrity no contexto de uma organização, o qual é recorrente nesse relatório. Para ela,

\begin{abstract}
integridade de gestão refere-se às atividades desenvolvidas para estimular e reforçar a integridade e prevenir a corrupção e outras violações de integridade dentro de uma organização particular. A estrutura de uma organização de gerenciamento de integridade, então, se refere ao conjunto desses instrumentos dessa organização, levando em consideração a sua interdependência, bem como os processos e as estruturas que trazem esses instrumentos para a vida. O contexto de integridade de uma organização refere-se a todos os fatores, além da estrutura de gerenciamento de integridade, que podem ter um impacto sobre a integridade dos membros em organizações do setor público. Isso inclui fatores e instrumentos, tanto no interior (o contexto interno) e fora (o contexto externo) da organização (MENDES, 2014:17).
\end{abstract}

Esse relatório, prescrito pela Organização para Cooperação e Desenvolvimento Econômico (OCDE), em 1998, expõe que as reformas gerenciais devem prover ferramentas que desenvolvam um elevado modelo de conduta e que tais mecanismos sejam promovidos no serviço público. Tal documento recomenda aos governos que se esforcem na promoção da 
responsabilidade e discrição dos seus agentes públicos. Essa foi uma medida tomada para estimular o combate à corrupção. Além da OCDE, a Organização das Nações Unidas (ONU), bem como a Organização dos Estados Americanos (OEA) fizeram acordos que o Brasil ratificou no começo dos anos 2000 (MENDES, 2014).

Em momento anterior nesta Dissertação, apresentou-se o contexto em que o Brasil se encontrava quando confirmou esse acordo internacional. O país estava em um contexto conturbado, quanto ao cenário político e também econômico, e que urgia a necessidade de uma reforma gerencial que trouxesse uma maior participação popular nas tomadas de decisões. "Assim, pressões em nível externo e interno indicam a necessidade de promover ação específica de combate à corrupção e promoção da ética” (MENDES, 2014:14).

O documento Towards a sound integrity framework: instruments, processes, structures and conditions for implementation OECD - Public Governance Committee, 2009, presta maiores esclarecimentos sobre os instrumentos de gestão da ética, a partir do entendimento de Mendes (2014), a saber:

a gestão da ética é a capacidade de reunir e compatibilizar instrumentos de natureza normativa, pedagógica e estrutural que proporcionem a promoção da ética no ambiente organizacional. Os valores definidos como próprios da instituição integrados às regras que disciplinam a conduta e orientam as ações dos agentes criam condições tanto para promover a ética quanto para coibir desvios (MENDES, 2014:19).

Do exposto, verifica-se que esses instrumentos possuem três características: normativa, pedagógica e estrutural, e que essas três vertentes devem buscar a promoção da ética na organização. Ainda em relação aos instrumentos de Gestão da Ética, Mendes descreve que o relatório "Towards a sound integrity framework: instruments, processes, structures and conditions for implementation", elaborado pela OCDE (2009), é

um modelo para a implementação da ética em instituições públicas. O olhar mais detido sobre o referido texto possibilita encontrar consonância do modelo proposto com os parâmetros adotados pelo Governo Federal. A base teórica utilizada nesse modelo traz influências da teoria ética empresarial - Linda Klebe Treviño; Lynn Sharp Paine e Gary R. Weaver e está fundamentado na orientação por cumprimento e por valores. Verificou-se, ainda, que a União Europeia também utiliza esse 
modelo. Para Nastase (2013), é provável que a OCDE tenha sido a mais proeminente defensora da utilização de ferramentas para gestão da ética como resposta frente aos desafios da decadência dos padrões éticos na administração pública em virtude de práticas de mercado (MENDES, 2014:90).

Assim, verifica-se que tal relatório representa um guia de como implementar a ética nas organizações públicas, e que, portanto, tem sido usado pelos governos como orientação para a elaboração de seus normativos, com instruções de ferramentas, para a Gestão da Ética, além de trazer a proposta de um padrão global que promova a ética, representa um instrumento de resistência à corrupção em órgãos públicos (MENDES, 2014)

A autora, acrescenta que "O modelo da OCDE (2009) se fundamenta em três pilares: 1) instrumentos; 2) processos; 3) estruturas. Os instrumentos têm o objetivo de estimular, aplicar e prevenir violações à ética por meio de organização específica." (MENDES, op. cit.:99).

Os três pilares, representam medidas de prevenção em relação a condutas antiéticas praticadas nas organizações. Verifica-se que normas de funcionamento da Comissão de Ética como o código 1171/94 e a Resolução n. 10, de 29 de setembro de 2008, da Comissão de Ética Pública, apoiam-se nos preceitos desse documento ao "padronizar as ações das comissões integrantes do Sistema de Gestão da Ética" (MENDES, op.cit:140). A autora explica que esses instrumentos se organizam em quatro funções principais: determinar e prevenir, orientar, monitorar e aplicar a ética. O segundo pilar refere-se à atividade contínua de planejar, implementar, avaliar e adaptar. Por fim, as estruturas são os aspectos organizacionais da gestão da ética, ou seja, definir responsáveis e como coordenar iniciativas de diversos atores cujas ações impactam na conduta ética dos membros da organização.

Com relação aos três pilares, Mendes (2014:101) apresenta o seguinte quadro: 
Quadro 2. Modelo de Gestão da Ética: três pilares e duas camadas

\begin{tabular}{|c|c|c|c|}
\hline & Instrumentos & Processos & Estruturas \\
\hline $\begin{array}{l}\text { Medidas } \\
\text { Fundamentais }\end{array}$ & $\begin{array}{l}\text { Códigos, regras, orientações, } \\
\text { capacitação e recomendações para } \\
\text { ética, divulgação de conflito de } \\
\text { interesses, etc. }\end{array}$ & $\begin{array}{l}\text { Processo de desenvolvimento } \\
\text { global e contínuo da ética. } \\
\text { Processo de desenvolvimento } \\
\text { contínuo em cada } \\
\text { instrumento, projeto único } \\
\text { para introduzir ou modificar } \\
\text { instrumentos. }\end{array}$ & Atores éticos, gestão. \\
\hline $\begin{array}{l}\text { Medidas } \\
\text { Complementares }\end{array}$ & $\begin{array}{l}\text { Ética como critério de seleção e } \\
\text { promoção de pessoas. Aspectos } \\
\text { éticos como procedimento de } \\
\text { gestão de compras e contratos, } \\
\text { inclusão da ética como ferramenta } \\
\text { de avaliação de qualidade, etc. }\end{array}$ & $\begin{array}{l}\text { Processos em gestão de } \\
\text { pessoas, gestão de compras e } \\
\text { contratos, gestão financeira, } \\
\text { etc. }\end{array}$ & $\begin{array}{l}\text { Gestão de pessoas, } \\
\text { gestão de contratos, } \\
\text { gestão financeira, etc. }\end{array}$ \\
\hline
\end{tabular}

Fonte: OCDE (2009:22)

Mendes (op.cit:101) apresenta mais dois outros quadros, elaborados pela OCDE, com tradução da autora, em que são classificados os instrumentos de Gestão da Ética em nível fundamental e complementar, conforme o que segue.

\section{Quadro 3. Classificação dos Instrumentos de Gestão da Ética - Nível Fundamental e}

Complementar

\begin{tabular}{|c|c|c|c|c|c|}
\hline & & $\begin{array}{c}\text { Determinar e definir } \\
\text { ética }\end{array}$ & $\begin{array}{c}\text { Orientar para a } \\
\text { ética }\end{array}$ & Monitorar a ética & Aplicar a ética \\
\hline 焉 & 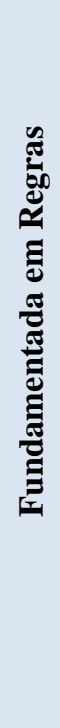 & $\begin{array}{l}\text { - Análise de risco } \\
\text { - Código de conduta } \\
\text { - Política sobre } \\
\text { conflito de interesses } \\
\text { - Política sobre } \\
\text { brindes e presentes } \\
\text { - Procedimentos sobre } \\
\text { afastamentos } \\
\text { - Medidas Estruturais }\end{array}$ & $\begin{array}{l}\text { - Capacitação ética, } \\
\text { fundamentada em } \\
\text { regras } \\
\text { - Juramento, } \\
\text { assinatura de } \\
\text { "Declaração de } \\
\text { ética" } \\
\text { - Orientação; } \\
\text { Aconselhamento }\end{array}$ & $\begin{array}{l}\text { - Política de } \\
\text { denúncia } \\
\text { - Política de } \\
\text { reclamações } \\
\text { - Inspeções } \\
\text { - Testes de ética } \\
\text { - Sistema de alerta } \\
\text { prévio } \\
\text { - Registro } \\
\text { sistemático de } \\
\text { reclamações e } \\
\text { investigações } \\
\text { - Pesquisas de } \\
\text { medida de } \\
\text { violações e clima } \\
\text { organizacional }\end{array}$ & $\begin{array}{l}\text { Sanções formais } \\
\text { Procedimentos para } \\
\text { lidar com desvios } \\
\text { éticos }\end{array}$ \\
\hline
\end{tabular}




\begin{tabular}{|c|c|c|c|c|c|}
\hline 苞 & 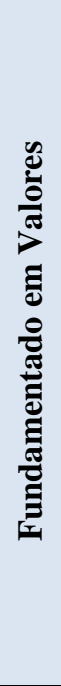 & $\begin{array}{l}\text { Análise dos dilemas } \\
\text { éticos } \\
\text { Consultas a membros } \\
\text { e colaboradores } \\
\text { Código de ética } \\
\text { Conjunto de padrões } \\
\text { não escritos }\end{array}$ & $\begin{array}{l}\text { - Capacitação ética } \\
\text { fundamentada em } \\
\text { valores } \\
\text { - Integração da } \\
\text { ética no discurso } \\
\text { (divulgar a política } \\
\text { de promoção da } \\
\text { ética dos canais de } \\
\text { comunicação } \\
\text { interno e externo) } \\
\text { - Conduta exemplar } \\
\text { dos dirigentes } \\
\text { - Treinamento e } \\
\text { aconselhamento } \\
\text { para ética }\end{array}$ & $\begin{array}{l}\text { - Medidas de } \\
\text { pesquisa para } \\
\text { dilemas éticos } \\
\text { - Sondagens } \\
\text { informais sobre } \\
\text { dilemas éticos e } \\
\text { questões entre } \\
\text { membros }\end{array}$ & Sanções informais \\
\hline \multirow[b]{2}{*}{ 离 } & & $\begin{array}{l}\text { Determinar e } \\
\text { definir ética }\end{array}$ & $\begin{array}{c}\text { Orientar para a } \\
\text { ética }\end{array}$ & Monitorar a ética & Aplicar a ética \\
\hline & & \multicolumn{2}{|c|}{$\begin{array}{l}\text { - Aplicar justiça como recompensa e sistema } \\
\text { de promoção. } \\
\text { - Procedimentos apropriados para aquisição, } \\
\text { contratos administrativos e pagamentos. } \\
\text { - Medidas de administração de pessoal (ética } \\
\text { com critério de seleção, avaliação e } \\
\text { promoção na carreira). } \\
\text { - Medidas de administração financeira } \\
\text { - Medidas de administração de informação } \\
\text { (proteção automática de bases de dados). } \\
\text { - Medidas de administração de qualidade } \\
\text { (revisão das ferramentas e avaliação das } \\
\text { qualidades). }\end{array}$} & $\begin{array}{l}\text { Controle e } \\
\text { auditoria interna } \\
\text { Controle e auditoria } \\
\text { externa }\end{array}$ & \\
\hline
\end{tabular}

Fonte: OCDE (2009:28).

Assim, verifica-se que o relatório da OCDE prescreve instrumentos de Gestão da Ética, os quais estão organizados em quatro funções principais, como dito anteriormente: determinar e definir ética, orientar para a ética, monitorar a ética e aplicar a ética. Essas recomendações podem ser acrescidas aos instrumentos levantados neste estudo, e com a teoria andragógica, haja vista a teoria da andragogia tratar de procedimento educativo para adultos e os instrumentos de gestão indicados pelos teóricos, atenderem a função de orientar para a ética. As classificações dos instrumentos de gestão da ética expostas nesses quadros da OCDE, revelam a quantidade de ferramentas que podem ser utilizadas pelas Comissões na busca por uma gestão eficaz da ética. 


\title{
2.8 Instrumentos de Gestão da Ética como Proposta de Práticas Educativas
}

No âmbito de uma organização, tem-se o material humano que representa a força motora da instituição, pessoas que carregam consigo toda uma história de vida, bem como determinado caráter e costumes, posto que vivenciaram culturas diferentes e educações familiares distintas. Muitas vezes, o conflito é inevitável, haja vista os posicionamentos diversos dos partícipes da organização. A confusão instaura-se não só de funcionário para funcionário, mas também em afronta aos valores e objetivos organizacionais. Portanto, é necessário que sejam adotadas medidas inibidoras e preventivas. Os instrumentos que serão apresentados, a seguir, funcionam como práticas educativas a serem adotadas.

Desse modo, são propostas algumas práticas da ética aplicadas por Matos (2008) em organizações, as quais representam iniciativas concretas e que poderão ser utilizadas pela Comissão de Ética da UnB, embora algumas dessas práticas, de certa forma, já estejam sendo implementadas, nada impede o seu aprimoramento. Matos (2008:78) destaca as seguintes práticas:

\begin{abstract}
Filosofia empresarial - por meio da clara conceituação de missão, princípios e orientações; comitê de ética - criação de grupo para definir e avaliar políticas e estratégias - formulação de diretrizes éticas; credos - divulgação das crenças institucionais - perfil e padrões - para funcionários e clientes; diretrizes éticas coletânea de preceitos sobre comportamentos esperados - como temos afirmado preferimos "Diretrizes Éticas" a "Códigos"; ombudsman - ouvidores colocados ao alcance dos clientes para atenderem a seus reclamos; auditorias éticas - avaliações periódicas sobre condutas empresariais; linhas diretas - circuito aberto a críticas, reclamações e sugestões; promoções educacionais - aproximação da empresa com seus públicos - internos e externos - por meio de iniciativas que eduquem; balanço social - divulgação dos investimentos da empresa, realizados em benefício do público interno e da comunidade.
\end{abstract}

Sendo assim, com base nas práticas éticas citadas por Matos (op.cit.), realiza-se um paralelo do que já vem sendo feito pela Comissão de Ética da UnB, e o que poderá ser aplicado, conforme descrito a seguir. 


\subsubsection{Filosofia Empresarial}

A Universidade de Brasília - UnB tem como missão

"produzir, integrar e divulgar conhecimento, formando cidadãos comprometidos com a ética, a responsabilidade social e o desenvolvimento sustentável. Seus valores incluem: ética e respeito à diversidade, autonomia institucional com transparência e responsabilidade social. Busca permanente de excelência. Universalização do acesso. Respeito à dignidade, à liberdade intelectual e às diferenças. Preservação e valorização da vida. Negócio da UnB: Conhecimento" (UnB, 2014). [grifo nosso]

Do exposto, verifica-se que a questão ética faz parte da missão e dos valores da

UnB, e, sendo assim, essa pesquisa contribui para o cumprimento dessa missão.

\subsubsection{Comissão de ética}

Nesta sessão, transcrevessem-se os itens de 1 a 4, expostos pelo Presidente da Comissão de Ética, Marcel Bursztyn, em entrevista à UNBAGENCIA, em que explica o papel da Comissão e seus fundamentos legais, afirmando que

1. A Comissão de Ética foi criada em 23.7.2008, pelo reitor pro tempore, Roberto Armando Ramos de Aguiar, em ato da Reitoria n. 1.377/2008. O fundamento legal é o Decreto 1.171/1994, que aprovou o Código de Ética Profissional do Servidor Público Civil do Poder Executivo Federal e deu prazo de 60 dias para que os órgãos da administração direta e indireta constituíssem as suas Comissões de Ética. A UnB demorou 14 anos para dar cumprimento a essa determinação (BURSZTYN, In: UNBAGÊNCIA, 2011)

O item 1 mostra o que já havia sido dito em momento precedente no presente trabalho, acrescentado pela fala do então Presidente da Comissão o prazo dado para que os órgãos instituíssem as Comissões em 60 dias, o mesmo cabendo a Universidade de Brasília, um órgão público da administração indireta, por meio da Fundação, a FUB, mas que não realizou no tempo hábil determinado a concretização da norma legal para instituição de sua Comissão de Ética, cumprindo a determinação, somente 14 anos depois. Isso revela que por 
muito tempo permaneceu esse eco, ou lacuna, na personalidade da Universidade de Brasília. A norma, porém, foi efetivada em vinte e três de setembro de dois mil e oito, conforme texto abaixo:

2. a Comissão de Ética tem como missão divulgar e zelar pelo cumprimento do Código de Ética Profissional do Servidor Público Civil e, complementarmente, do Código de Conduta próprio da instituição, além de atuar como órgão consultivo interno às instituições. O país já conta com mais de 100 comissões de ética cadastradas no Sistema de Gestão da Ética. O Sistema de Gestão da Ética foi instituído pelo Decreto 6029/2007, cujo detalhamento de rito processual foi estabelecido pela Resolução 10/2008, da Comissão de Ética Pública da Presidência da República (BURSZTYN, In: UNBAGÊNCIA, 2011).

Isso evidencia que a Universidade de Brasília, ainda que considerada em atraso, conforme visto anteriormente, fez parte em 2008 de uma corrente de integração ao Sistema de Gestão de Ética ocorrida no país, quando então já se contava com mais de 100 comissões de ética cadastradas no referido sistema. Quanto à finalidade da Comissão de Ética, Bilhin e Gonçalves (2012:4) afirmam que

a Comissão de Ética tem como finalidade promover valores e princípios prevalentes
na sociedade brasileira que reflitam a conduta ética do servidor público federal. A
instituiçãa da Secretaria-Executiva formaliza, assim, o processo de
institucionalização da ética no serviço público que passa a ser representado na
estrutura organizacional do órgão com recursos definidos para a execução das
atividades. De modo a acrescentar, pode-se dizer que os 'valores e princípios que a Comissão tem como finalidade promover' está positivado no código 1.171/94, que corrobora com a citação acima, 'valores e princípios prevalentes na sociedade brasileira'.

A institucionalização da Secretaria-Executiva se faz necessária, por ser a secretária a única que não possui mandato temporário, como nos casos dos membros, o que faz perdurar no tempo uma memória maior dos trabalhos e deliberações das comissões, facilitando, assim, os trabalhos futuros que serão desenvolvidos por novos membros, além de 'formalizar o processo de institucionalização'. 
A UnB não tem ainda um Código de Ética próprio, mas utiliza a dos servidores públicos (Decreto n ${ }^{\circ}$ 1.171/94). A divulgação do Código de Ética tem ocorrido através do site da Comissão no portal da UnB e por meio de palestras.

3. A Comissão de Ética atua quando provocada pela comunidade institucional ou pelos usuários dos serviços da UnB. As denúncias podem ser apresentadas por qualquer pessoa física ou jurídica. A fase inicial de recepção das denúncias é chamada de "Procedimento Preliminar, etapa em que se analisa a admissibilidade e, em caso positivo, inicia-se o "Processo de Apuração Ética" (PAE). O resultado de um PAE pode ser: a) arquivamento, comprovada a inocência; b) proposição ao investigado de "Acordo de Conduta Pessoal e Profissional" (ACPP); c) aplicação de censura ética, respeitado o direito à ampla defesa e contraditório (BURSZTYN, In: UNBAGÊNCIA, 2011).

Do exposto, verifica-se o cumprimento do disposto no rito processual da

Comissão de Ética, presente na Resolução n ${ }^{\circ}$ 10/ 2008. O rito é seguido pelas Comissões de Ética locais (antiga denominação era: Comissões de Ética Setoriais) em atendimento a essa Resolução, assim como pela Comissão de Ética da UnB, posto que esta também é uma Comissão de Ética local.

4. A Comissão de Ética é constituída por 3 membros titulares e respectivos membros suplentes, com mandatos não coincidentes de 3 anos, escolhidos entre servidores do quadro permanente e designados pelo dirigente máximo da instituição. A Comissão de Ética não é um órgão político ou tribunal judicial. Há uma diferença entre lei e ética que cabe à Comissão de Ética, com independência, zelar e promover institucionalmente. A Comissão de Ética da Universidade de Brasília conta com 5 professores e 1 servidora técnica administrativa como membros. Nenhum de seus membros é remunerado pelo exercício das funções e devem realizar o ofício com discrição e confidencialidade. Os membros da Comissão de Ética - UnB dedicam os seus melhores esforços no sentido do fiel cumprimento dos mandatos a eles confiados e estarão sempre empenhados em levar adiante sua missão em favor da ética e pelo aprimoramento das relações humanas dentro desta grande comunidade que convive diariamente nos quatro Campi da Universidade (BURSZTYN, In: UNBAGÊNCIA, 2011; UNB, 2014).

A configuração apresentada pelo entrevistado continua sendo a mesma, em relação ao número de membros professores e uma técnica administrativa. Quanto à diferença de lei e ética referenciada, isso se dá porque cabe à comissão analisar e deliberar apenas em sua matéria, ou seja, fazer o recorte ético no processo, e caso a matéria extrapole a sua competência, ela deve encaminhar o caso para o dirigente máximo da instituição, que, por sua vez, fará os devidos encaminhamentos. 


\title{
2.8.3 Formulação de diretrizes éticas
}

Os dias atuais são de tecnologias em tempo real, de globalização, de quebra de fronteiras, de diversidade e responsabilidade social. Nesse cenário, serão respeitados, aqueles que prementemente adotarem posturas absolutamente corretas nas relações pessoais, na política e nos negócios. Durante o II Congresso Nacional sobre Investimento Social Privado, promovido pelo GIFE (Grupo de Institutos, Fundações e Empresas), em abril de 2002, o representante da Organização das Nações Unidas para a Educação, a Ciência e a Cultura UNESCO, no Brasil, revelou o necessário estabelecimento de um Código de Ética Universal:

\begin{abstract}
esse novo cenário de harmonia multicultural que todos nós desejamos requer sacrifícios continuados e uma visão estadista, para trabalharmos o advento de uma nova ética universal. Para tanto, torna-se essencial e imperativo 'identificar um núcleo de valores e princípios éticos comuns' a todas as culturas para serem aceitos e colocados como 'pontos de referência partilhados de forma a estabelecer um guia mínimo de moral a ser considerada pela comunidade mundial' [...] (TARAPANOFF, 2006; UNESCO, 2015)
\end{abstract}

O que se deseja transmitir é que conceitos [ou valores] tais como ética e moral sejam vistos como adequados e necessários, e que sem esses valores [ou conceitos] não há como se promover um prosseguimento seguro, justo e sustentável nas organizações, e, assim por dizer, na própria sociedade tanto na sua forma intrínseca (particular) como na extrínseca (aqui entendida, como o da administração pública que rege o Estado Democrático de Direito). Nas palavras de Pedro Lenza,

no âmbito das relações particulares, pode-se fazer tudo o que a lei não proíbe, vigorando o princípio da autonomia da vontade, lembrando a possibilidade de ponderação desse valor com o da dignidade da pessoa humana e, assim, a aplicação horizontal dos direitos fundamentais nas relações entre particulares, conforme estudado", também elucida que "em relação à administração, ela só poderá fazer o que a lei permitir. Deve andar nos "trilhos da lei" (LENZA, 2012:979). [grifo nosso] 
Depreende-se do exposto, que a Ética é um conceito integrante das relações humanas, bem como das relações nas organizações pessoais, na política e nos negócios, não havendo espaço para que o ser humano aja de modo divergente. Em especial, o servidor público, na fala de Lenza (op.cit.), deve andar nos 'trilhos da lei'.

\subsubsection{Ombudsman (Ouvidores)}

Quanto aos ouvidores colocados ao alcance dos clientes para atenderem a seus reclamos, a Comissão de Ética da UnB é acessível através dos seguintes canais: por telefone: (61) 3107-0234; por e-mail: < eticaunb@unb.br >; pessoalmente: Campus Universitário Darcy Ribeiro, Prédio da Reitoria, Gabinete do Reitor, $3^{\circ}$ andar, Sala A3-14/10; e através do site: $\langle\underline{\text { www.comissaodeetica.unb.br/ }}>$.

O Site < www.comissaodeetica.unb.br/ > passou por uma reformulação, com o objetivo de facilitar o acesso dos visitantes, quanto às seguintes informações: como demandar a Comissão de Ética/ UnB; Fale Conosco; Tire suas dúvidas/FAQ; Informação ética da semana, a qual visa à instrução ética contida no Decreto $\mathrm{n}^{\circ} 1.171$, de 22 de junho de 1994; Relatórios dos trabalhos da Comissão; Consulta e orientações; Ementas e decisões; Legislação, Regimento Interno; Composição da Comissão, com a indicação da presidente, membros e secretária- executiva, um breve relato sobre o que é a Comissão de Ética e qual a sua competência.

Las Casas (2006:377) revela que "ao divulgar um produto ou serviço, os consumidores poderão se sentir estimulados a comprá-lo, tanto pelo efeito da persuasão da comunicação, como pela informação que adquirem.” Ao trazer esta citação para realidade de um órgão público, os efeitos são os mesmos, haja vista a importância da divulgação de 
trabalhos, com vistas à efetividade de ações. Quanto à questão do 'comprar', o mesmo autor diz que pode ser usada em analogia ao acesso da comunidade universitária, por meio dessa ferramenta midiática, aos serviços da Comissão de Ética da UnB. A figura 1 apresenta a tela do site da Comissão de Ética da UnB.

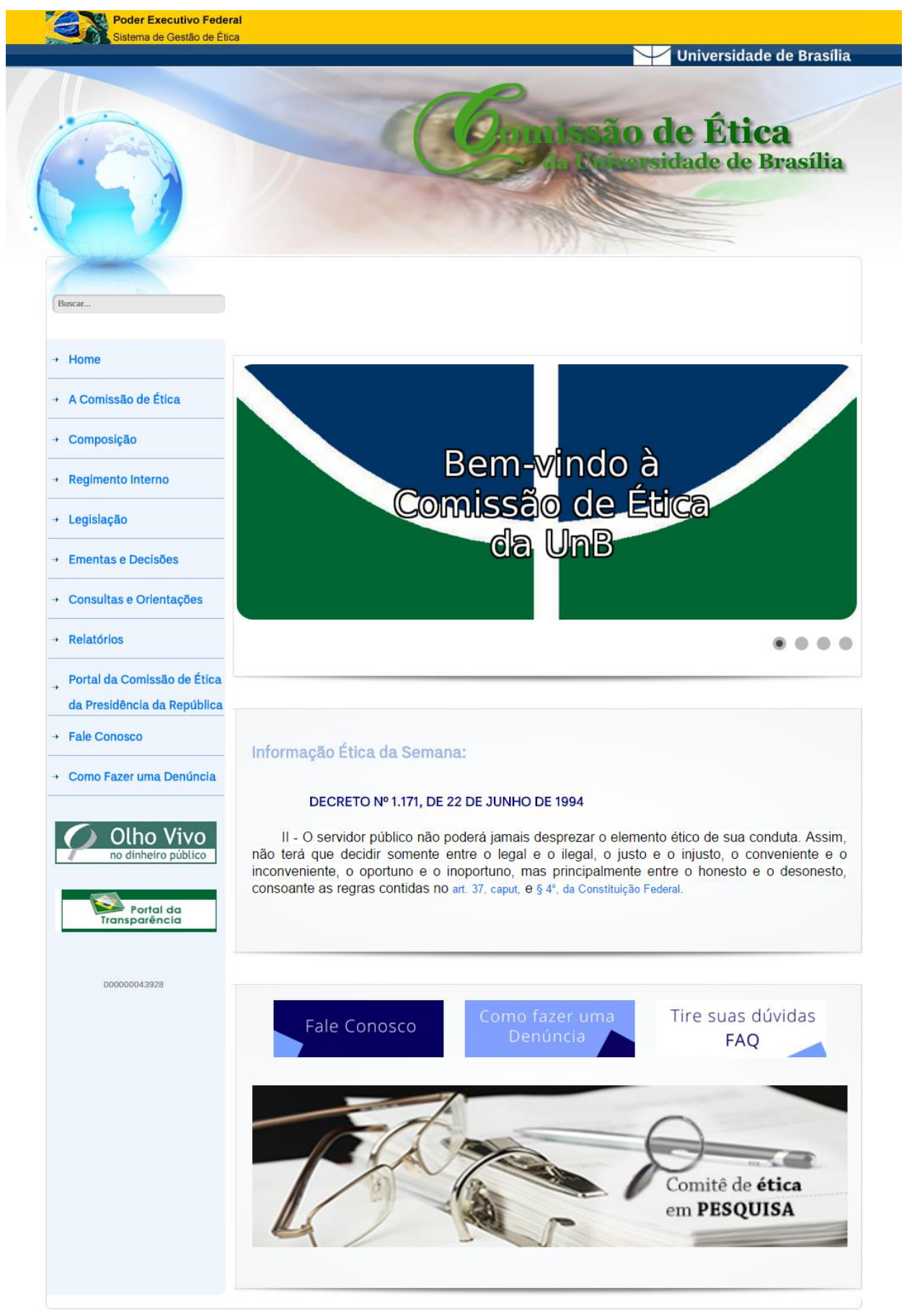

Figura 1. Página inicial do Site da Comissão de Ética/ UnB Fonte: Site da Comissão de Ética/UnB. 
O portal da Comissão de Ética tem por finalidade publicar as ações da Comissão de Ética da UnB, atendendo ao princípio ético da transparência e publicidade, ressalvados os dados sigilosos que são ocultados na publicação dos documentos desta comissão. O portal da Comissão de Ética da UnB é também um canal de comunicação com a comunidade acadêmica. A este respeito, Kunsch (2003:90) expõe que

\begin{abstract}
as organizações têm de se valer de serviços integrados nessa área, pautando-se por políticas que privilegiem o estabelecimento de canais de comunicação com os públicos vinculados. A abertura de fontes e a transparência das ações serão fundamentais para que as organizações possam se relacionar com a sociedade e contribuir para a construção da cidadania na perspectiva da responsabilidade social.
\end{abstract}

Em relação a divulgar os atos públicos Kant (apud BOBBIO \& NOGUEIRA, 1997:28) diz que, “todas as ações relativas ao direito de outros homens, cuja máxima não é suscetível de se tornar pública, são injustas". Soares (2007:65), por sua vez, relata que "a lei inclusive impõe ao administrador público o dever de publicar os atos [...]. A publicidade, no âmbito dos órgãos públicos, é exigência expressa da Constituição Brasileira, em diversos dispositivos”. "Quando se fala em 'publicidade', nesta seara do conhecimento, refere-se, ao 'ato de divulgar, de tornar público"”.

Conforme já dito, a Comissão de Ética da UnB é vinculada à Comissão de Ética Pública da Presidência da República, e é responsável por apurar eventuais violações ao Código de Ética do Servidor Público Civil do Poder Executivo Federal (Decreto $\mathrm{n}^{\mathrm{o}}$ 1.171/1994). Para a revisão ética de atividades de pesquisa, a UnB dispõe de Comitês de Ética em pesquisa. Em relação a esses comitês, o site da comissão disponibiliza uma página com a indicação de telefone e site respectivo, além de link da CGU e do Portal de Transparência Pública. 


\subsubsection{Auditorias Éticas - Avaliações Periódicas sobre Condutas Empresariais}

A Comissão de Ética Pública da Presidência da República faz visita a órgãos do poder executivo federal para verificar os trabalhos realizados por essas comissões. Registra-se aqui, que é possível qualquer instituição antever-se às auditorias externas e realizar sua própria auditoria interna. A ideia é de renovação e mudança de atitudes, inclusivamente para o Regimento Interno da Comissão de Ética da UnB, onde ficaria instituído a contratação de uma auditoria interna de forma terceirizada, ocorrendo periódica e anualmente.

\subsubsection{Promoções Educacionais - Aproximação da Empresa com seus Públicos Internos e Externos}

Em relação a esta prática ética realizada por Matos (2008), a Comissão de Ética da UnB já promoveu algumas palestras em conjunto com a Coordenadoria de Capacitação e Educação (PROCAP). Este é um ponto das categorias identificadas na análise de resultados a frente apresentada. Desde já, com base em Matos (2008), pode-se dizer que há uma necessidade de uma intensificação de ações educativas na UnB. Faz-se necessário investir em atividades pedagógicas capazes de promover o esclarecimento e imprimir uma nova mentalidade, novos valores e, consequentemente, nova relação da população com o serviço público. As normas codificadas e as punições podem ajudar, porém, são incapazes de fazer a passagem necessária (PASSOS, 2010:163).

Diante do exposto, Passos (2010) esclarece que imprimir uma nova mentalidade no ambiente organizacional, por meio de atividades pedagógicas, deve-se agir para que essas 
ações provoquem o 'meio envolvente'. Conforme revela Fonseca (1997:14) “o sucesso e a sobrevivência das organizações são atingidas se estes se adaptarem ao seu meio envolvente e se forem capazes de manter um equilíbrio estável naquele enquadramento". Assim, para alcançar o sucesso, bem como a sobrevivência, não basta apenas implementar e, assim adaptar ao meio, é necessário a "manutenção do sistema de trabalho". Se há resistência das pessoas em participar dessas promoções educacionais, Sales e Silva revelam a solução, a qual foi manifestada a partir de um estudo de caso:

[...] o mau planejamento, as falhas de comunicação, a ausência de um líder participativo e atuante são fatores geradores de resistência, portanto esta não é necessariamente um obstáculo a ser enfrentado, ela pode ser encarada como uma forma de evitar um mal resultado ao final da implantação de mudanças (p.15) e acrescenta "é preciso quebrar o paradigma da resistência, deixar de vê-la como a grande vilã ou algo que deva ser ultrapassado, eliminado. Já está chegada a hora de mudar a visão e encarar a resistência como algo que vá auxiliar o processo de mudanças, já que esta pode servir como ferramenta para identificar problemas, falhas e mau planejamento. Além disso, a resistência pode contribuir para proporcionar um clima altamente dinâmico, flexível e mutável dentro das organizações, observando-se novos modelos de gestão (SALES \& SILVA, 2007:15).

De modo a reforçar o exposto, Fischer et al. revelam que e necessário aprender a

administrar as diferenças de cultura organizacional e a compatibilizar os diversos níveis de poder econômico e político das organizações envolvidas. Assim, fatores como: superação de obstáculos práticos; resolução de dilemas estratégicos através de um diálogo aberto e regular; demonstração de que estes mecanismos adicionam valor ou trazem benefícios para os participantes e para a sociedade; desenvolvimento de rigorosas ferramentas gerenciais para lidar com os processos e impactos; quando combinados, podem aumentar o potencial das parcerias para a resolução de problemas [...] (FISCHER et al., 2003:8).

Fischer et al (op.cit.:8) relatam que para a superação das diferenças de uma cultura organizacional, é necessário adotar algumas medidas para a superação dos obstáculos práticos, são elas: “o diálogo aberto e regular; demonstração de que estes mecanismos adicionam valor ou trazem benefícios para os participantes; desenvolvimento de rigorosas ferramentas gerenciais". 


\subsubsection{Balanço Social}

Para que ocorra o balanço social, é necessário que haja a divulgação dos investimentos da empresa, realizados em benefício do público interno e da comunidade. Essa proposta é, na verdade, um direito da sociedade brasileira, bem como um dever da Gestão da Administração Pública, em observância aos princípios constitucionais fulcrados no art. 37 da Constituição Federal Brasileira, quais sejam: legalidade, impessoalidade, moralidade, publicidade e eficiência (FIGUEIREDO \& SANTOS, 2013).

A boa governança pública, que é a evolução do termo 'nova administração pública', que, segundo Souza e Siqueira (2007), está relacionada com a Nova Gestão Pública, é utilizada para o melhor gerenciamento de seus processos e atividades, a eficácia e efetividade nos seus resultados, promovendo a prestação de contas responsável (accountability) e a transparência de suas ações (BIZERRA, 2011).

O alcance dessa postura é uma das diretrizes que este trabalho busca alertar de forma pedagógica [ou melhor dizendo, andragógica] à Comissão de Ética da Universidade de Brasília. 


\section{PERCURSO METODOLÓGICO}

No dia a dia mais comum, há uma necessidade de organização. “A esta ordem, na esfera do conhecimento, da investigação (pesquisa) ou de qualquer outra atividade intelectual ocorre por meio de método, que associados ao termo metodologia traduz um processo de conhecimento" (MEZZAROBA \& MONTEIRO, 2004:49). Metodologia - méthodos -, significa o caminho a ser percorrido para chegar a um fim, enquanto logos indica estudo sistemático, investigação. Nesse sentido, metodologia significa o estudo dos caminhos a serem seguidos, incluindo, aí, os procedimentos escolhidos.

Três obras representam a âncora para a realização deste trabalho: Elizete Passos, com a obra ‘Ética nas organizações' (2010); Francisco Gomes de Matos, com a obra 'Ética na gestão empresarial' (2008) e Annita Valléria Calmon Mendes, com a tese 'A administração pública e o sistema de gestão da ética: uma análise da política de promoção da ética no Poder Executivo Federal' (2014).

Tais obras traduzem a evolução do pensamento acerca da importância que se fez perceber da ética dentro da administração, traduzida em uma questão de realização da justiça social, que hoje representa a concretização, e, ainda a materialização do direito ao desenvolvimento [de uma sociedade, de um cidadão, e também de uma instituição].

Parte-se da certeza de que o conhecimento científico não se distorce do mundo real. Em um mundo impregnado de tecnologia, e vítima da velocidade dos fatos - em tempo real -, entender a pessoa humana, em suas funções públicas, no contexto deste trabalho, capaz de transportar seus valores adquiridos por conhecimentos e práticas educativas, portanto, 
valores mais elevados, como é a ética, foi fonte constante de inspiração para o trabalho ora apresentado.

Dessa forma, neste capítulo são apresentados os procedimentos adotados na metodologia deste estudo; o perfil dos servidores entrevistados; como foi efetuada a entrevista; a apresentação da Comissão de Ética na UnB, segundo os normativos e como ela está estruturada na Universidade de Brasília.

\subsection{Método De Estudo}

A pesquisa realizada adotou como metodologia, a pesquisa empírica, a qual, segundo Prodanov e Freitas (2013:126), é o “modo científico para obter conhecimento da realidade empírica [...] tudo que existe e pode ser conhecido pela experiência”. Utilizou-se do método de pesquisa exploratória, posto que esta é assim aplicada por ser entendida como "fundamentalmente motivada pela necessidade de resolver problemas concretos, mais imediatos, ou não" (VERGARA, 2004:48).

A pesquisa realizada teve como finalidade "proporcionar mais informações sobre o tema investigado, possibilitando sua definição e seu delineamento" (PRODANOV \& FREITAS, 2013:51,52). Dessa forma, a pesquisa utilizou-se do estudo bibliométrico, pesquisa documental, pesquisa bibliográfica e análise de conteúdo.

A opção pelo uso dessas metodologias dá-se por haver a oportunidade de realizar uma análise do conteúdo em função dos resultados obtidos, permitindo, a partir disso, uma compreensão das percepções sobre o tema objeto em estudo, com vinte e três servidores públicos da Universidade de Brasília - UnB. A análise de conteúdo permite ao leitor uma absorção de conhecimento necessário, que será desdobrado e aplicado à pesquisa realizada. 
Foram utilizados os seguintes critérios relativos ao design da pesquisa: quanto à natureza, é aplicada, posto que segundo Prodanov e Freitas (2013:126):, “[...] procura produzir conhecimentos para aplicação prática, dirigidos à solução de problemas específicos”. Como esta pesquisa visa à melhoria nas relações de trabalho, ela enquadra-se na aplicação prática.

O método científico utilizado é o dedutivo, por ser o mais adequado à proposta da presente pesquisa, porquanto, apresenta em suas análises de resultados [a seguir apresentados no próximo capítulo], com "o intuito de produzir enunciados que fundamentem o entendimento proposto" (VIEIRA, 2005:96). Esse método sugere ainda "uma análise de problemas do geral para o particular, através de uma cadeia de raciocínio decrescente" (PRODANOV\&FREITAS, 2013:127). Assim, o método é utilizado de modo a revelar os problemas e subsidiar a implementação de uma andragogia voltada para a afirmação da educação de adultos em relação à ética na universidade de modo contínuo.

A abordagem é um estudo de caso que, por ser qualitativo, revela que "o ambiente natural é fonte direta para coleta de dados, interpretação de fenômenos e atribuição de significados" (PRODANOV \& FREITAS, 2013:128). Além disso, o estudo de caso tem a capacidade de lidar com uma ampla variedade de evidências, conforme revela Yin (2001:20):

documentos, artefatos, entrevistas e observações, sendo assim é uma estratégia de pesquisa que pode ser utilizada na seguinte situação, supervisão de dissertações e teses nas ciências sociais - disciplinas acadêmicas e áreas profissionais como administração empresarial, ciência administrativa e trabalho social, bem como nos estudos organizacionais e gerenciais (YIN, 2001:20).

Os procedimentos técnicos utilizados foram o estudo bibliométrico na etapa da 'justificativa' do referido trabalho e em relação ao perfil dos sujeitos entrevistados. Segundo Naseer e Mahmood,

a bibliometria inclui dois tipos de estudos: descritivos e avaliativos. Os estudos descritivos referem-se à produtividade obtida pela contagem dos livros, periódicos e outros formatos de comunicação, enquanto que os estudos avaliativos, estão relacionados, ao uso da literatura por meio da contagem de referências e citações em trabalhos de pesquisas (NASEER \& MAHMOOD, 2009:115). 
Aplica-se também a este estudo a pesquisa bibliográfica e a documental, as quais perfizeram o item 'referencial teórico', as quais serviram de sustentação à análise dos resultados, mas à frente apresentada, e com base na coleta de dados de registros (em relação à instituição da Comissão de Ética - UnB), que foram extraídos de normas, decretos, resoluções, atos. Aplicou-se um roteiro de entrevista estruturada, seguindo os postulados de Aguiar e Medeiros que revelam que

este tipo de entrevista baseia-se na utilização de um questionário como
instrumento de coleta de informações, o que garante que a mesma pergunta será
feita da mesma forma a todas as pessoas que forem pesquisadas. Gil (1999:121)
explica que "a entrevista [...] desenvolve-se a partir de uma relação fixa de
perguntas, cuja ordem e redação permanece invariável para todos os entrevistados,
que geralmente são em grande número"”. (AGUIAR \& MEDEIROS, 2009). [grifo
nosso]

A utilização do instrumento de pesquisa, roteiro de entrevista estruturada (também denominada questionário), foi aplicada aos 23 entrevistados, sob um mesmo roteiro de entrevista, o que garantiu uma constância: "mesma pergunta foi feita da mesma forma às pessoas que foram entrevistadas" (AGUIAR \& MEDEIROS, 2009:10710). Assim, verifica-se que a entrevista estruturada geralmente é empregada nos censos, como, por exemplo, os do Instituto Brasileiro de Geografia e Estatística - IBGE, nas investigações de opinião, nas pesquisas eleitorais, nas investigações mercadológicas, observações de audiência, etc. (BONI \& QUARESMA, 2005). Desse modo, como objetivou-se realizar um levantamento de opiniões, optou-se pela entrevista estruturada.

Segundo esses teóricos, algumas das principais vantagens de um questionário é que nem sempre é necessário a presença do pesquisador para que o informante responda as perguntas. Ele garante também uma maior liberdade das respostas em razão do anonimato, evitando viés potenciais do entrevistador. Boni e Quaresma (2005) afirmam também que geralmente, através do questionário, obtêm-se respostas rápidas e precisas. 
Apesar do presente estudo apresentar a análise bibliométrica no levantamento de publicações, teses e dissertações, em bancos de dados - no item: 'Justificativa' deste estudo, e também em relação à parte inicial da entrevista estruturada, com dados estatísticos, tais como: gênero, idade e tempo de serviço - o estudo bibliométrico representa um papel menor na análise desse trabalho. Dalfovo e Lana (2008) complementam o entendimento ao explicarem que quando a pesquisa é qualitativa, assim o é porque trabalha predominantemente com dados qualitativos, ou seja, a informação coletada pelo pesquisador não é expressa em números, ou então os números e as conclusões neles baseados representam um papel menor na análise.

Em relação à análise de conteúdo, trata-se de uma técnica de tratamento de dados qualitativos que se aplica a 'discursos' bem diversificados. "A análise de conteúdo oscila entre a objetividade e a subjetividade" (BARDIN, 1977:9). Analisar o conteúdo das entrevistas consiste numa tarefa de 'desocultação', em que se é “agente duplo, detective, espião" (BARDIN, 1977:9). "Porquanto detrás de um qualquer texto, de uma qualquer opinião aparentemente clara esconde-se um significado, um sentido que é importante desvendar" (BARDIN, 1977:14).

\subsection{Descrição dos Servidores Entrevistados}

Com a predisposição em buscar estratégias para a efetiva implementação de práticas éticas educativas, no âmbito da UnB, e de modo a assegurar a qualidade da informação, fizeram parte da população deste estudo, 23 servidores públicos da UnB, a saber: os membros da Comissão de Ética, que atualmente está composta por cinco docentes e uma técnica administrativa; técnico-administrativos da Coordenação de Processo Administrativo Disciplinar - CPAD/ GRE, a qual é ligada diretamente ao Gabinete do Reitor (os servidores 
da CPAD/GRE trabalham em funções estratégicas na UnB, no sentido de desenvolverem atividades de cunho disciplinar na universidade, assim como os servidores que têm relação de trabalho com a comissão); as populações da Ouvidoria da Universidade de Brasília; a Coordenadoria de Capacitação e Educação - PROCAP do Decanato de Gestão de Pessoas DGP; o Serviço de Informação ao Cidadão (SIC). Todos os participantes foram convidados pessoalmente pela pesquisadora, para integrarem a presente pesquisa.

Ao observar os princípios éticos em pesquisa, o servidor que não concordou em participar da investigação não integrou a população. Assim, na busca de informações complementares e de modo a dar continuidade à estratégia de fazer um levantamento de sugestões para a implementação de práticas educativas para a ética na Universidade de Brasília foram feitos os seguintes levantamentos, por meio de estudo bibliométrico.

Ao fazer o levantamento dos dados, de verificação do gênero predominante entre os entrevistados, verificou-se que a maioria dos entrevistados são mulheres, haja vista dos 23 entrevistados, 14 serem do gênero feminino, o que corresponde a $61 \%$ do total. Esta representação corresponde à realidade da maioria dos departamentos entrevistados, com exceção da Coordenação de Processo Administrativo Disciplinar - CPAD, em que todos os entrevistados são do gênero masculino.

Em relação à idade, verifica-se que a faixa etária da maioria correspondente a $43 \%$ do total, entre 26 e 35 anos de idade, e que essa representação corresponde à realidade da maioria dos departamentos entrevistados, com exceção da Comissão de Ética da UnB em que a maioria dos membros possui mais de 36 anos, sendo que há um membro com 30 anos (do sexo feminino). Do total de 23 entrevistados, a faixa etária de 18-20 anos corresponde à 13\%; a de 21-25 anos, corresponde à 9\%; e a de 36-50 anos, $35 \%$.

No que diz respeito ao tempo de serviço no setor, verifica-se que o maior tempo de serviço, da maioria, correspondente a $74 \%$ do total, entre 0 e 3 anos de atividade. Essa 
representação corresponde à realidade da totalidade dos departamentos entrevistados. Do total de 23 entrevistados, no que diz respeito a tempo de serviço, observa-se que entre 4-6 anos, corresponde a $22 \%$ e de $7-9$ anos, apenas $1 \%$.

Sobre a lotação dos servidores, verifica-se que o departamento com maior número de servidores é a Coordenadoria de Capacitação e Educação - PROCAP, do Decanato de Gestão de Pessoas - DGP, que correspondente a 35\% do total. Essa representação corresponde a $13 \%$ a mais do que o departamento, imediatamente inferior, em número de servidores: CPAD e Comissão de Ética/UnB, e 27\% a mais que o setor com menor número de servidores: SIC. O quantitativo de entrevistados da Ouvidoria, por sua vez, representa $13 \%$ do total. Vale salientar que no levantamento desses dados não foram considerados os que não responderam ao questionário, pelos motivos a seguir: na CPAD um servidor estava afastado; na Comissão de ética, uma servidora estava em férias; na Ouvidoria, uma servidora se encontrava em licença saúde por acompanhamento; e na PROCAP/ DGP, dois servidores com estavam com licença por motivo de saúde. 
Quadro 4. Perfil dos 23 entrevistados

\begin{tabular}{|c|c|c|c|}
\hline Departamento & Gênero & Idade & $\begin{array}{c}\text { Tempo de serviço no } \\
\text { setor em que está } \\
\text { lotado } \\
\end{array}$ \\
\hline \multirow{5}{*}{$\begin{array}{c}\text { COMISSÃO DE } \\
\text { ÉTICA/UnB }\end{array}$} & Feminino & 30 & 1 ano \\
\hline & Feminino & 40 & 2 meses \\
\hline & Feminino & 45 & 5 anos com recondução \\
\hline & Masculino & 58 & 2 anos \\
\hline & Masculino & 36 & 4 anos com recondução \\
\hline \multirow[t]{2}{*}{ SIC } & Feminino & 48 & 3 anos \\
\hline & Feminino & 32 & 2 anos e meio \\
\hline \multirow{5}{*}{ CPAD/GRE } & Masculino & 27 & 1 ano e 4 meses \\
\hline & Masculino & 49 & 3 anos \\
\hline & Masculino & 25 & 3 anos e 4 meses \\
\hline & Masculino & 71 & 5 anos \\
\hline & Masculino & 28 & 9 anos \\
\hline \multirow{3}{*}{ OUVIDORIA } & Feminino & 50 & 2 anos \\
\hline & Feminino & 35 & 2 anos \\
\hline & Feminino & 34 & 2 anos \\
\hline \multirow{8}{*}{ PROCAP/DGP } & Feminino & 56 & 4 anos \\
\hline & Feminino & 47 & 4 anos \\
\hline & Feminino & 49 & 2 anos e 3 meses \\
\hline & Masculino & 34 & 1 ano \\
\hline & Masculino & 33 & 1 ano e 2 meses \\
\hline & Feminino & 35 & 3 dias \\
\hline & Feminino & 29 & 6 meses \\
\hline & Feminino & 25 & 6 meses \\
\hline
\end{tabular}

Fonte: elaborado pela autora, a partir dos dados da pesquisa, 2015.

\subsection{Roteiro De Entrevista Estruturada}

A primeira parte da coleta teve por objetivo fazer um levantamento da caracterização pessoal dos entrevistados, quanto à verificação do gênero predominante dos servidores que trabalham com a questão disciplinar e de informação à Comunidade Universitária, assim como a faixa etária da maioria, o tempo de serviço no atual setor, e o número de servidores 
por departamento. Esses dados contribuíram para a identificação do perfil dos entrevistados, dando suporte para as perguntas que compõem a segunda parte do roteiro.

A segunda parte do roteiro, por sua vez, objetivou levantar categorias que explicassem as seguintes subdimensões de estudo: Ética no Ambiente Laboral; Práticas Educativas e Instrumentos de Gestão da Ética Institucional; e Gestão da ética nas relações de trabalho; subdimensões, essas, que compõe a segunda macro dimensão, Gestão da Ética, haja vista a primeira macro dimensão tratar da legislação.

As perguntas (abertas), abaixo relacionadas, fazem parte da segunda parte do roteiro de entrevista estruturada, e estão relacionadas a uma determinada dimensão. As respostas a essas perguntas, por parte dos entrevistados, é que permitem a coleta de categorias que auxiliaram no entendimento dessas dimensões. Eis as perguntas do questionário:

1. O que você entende por ética nas relações interpessoais no ambiente laboral? Justifique.

2. Você acha que a Universidade apoia programas educativos para os servidores? Em caso positivo, como é dado esse apoio?

3. Partindo da premissa de que a educação ética, de uma forma geral, propicia uma vida melhor para as pessoas, o que você acha que a Comissão de Ética pode fazer para transformar essa expectativa em realidade?

4. Em caso negativo, em que na sua opinião, seria impossível o desenvolvimento de um trabalho de conscientização da ética na UnB, quais os motivos que impediriam essa implementação?

5. Em quais aspectos você considera como facilitadores e dificultadores do trabalho da Comissão de Ética na UnB? Justifique.

De modo a correlacionar as perguntas aplicadas nesse roteiro de entrevista estruturada às dimensões de estudo, e assim buscar atender aos objetivos específicos deste trabalho, haja 
vista que as perguntas elaboradas no roteiro da entrevista estruturada foram feitas com base nos objetivos aqui apresentados, elaborou-se o quadro a seguir:

Quadro 5. Roteiro de Entrevista

\begin{tabular}{|c|c|c|}
\hline DIMENSÕES DO ESTUDO & \multicolumn{2}{|c|}{ OBJETIVOS ESPECÍFICOS DO PRESENTE ESTUDO } \\
\hline LEGISLAÇÃO & \multicolumn{2}{|c|}{$\begin{array}{l}\text { Descrever atribuições da Comissão de Ética, } \\
\text { segundo os normativos, para a gestão ética da } \\
\text { Universidade de Brasília; }\end{array}$} \\
\hline GESTÃO DA ÉTICA & \multicolumn{2}{|c|}{$\begin{array}{l}\text { - } \quad \begin{array}{l}\text { Descrever a compreensão da dimensão ética nas } \\
\text { relações de trabalho no âmbito da Comissão de Ética } \\
\text { da Universidade de Brasília; }\end{array} \\
\text { - Investigar os aspectos facilitadores e dificultadores } \\
\text { do processo de trabalho educativo da Comissão de } \\
\text { Ética da UnB. } \\
\text { - Enunciar as possibilidades de implantação de } \\
\text { instrumentos de gestão da ética } \\
\text { - Recomendar ações que contribuam para a educação } \\
\text { ética na Universidade de Brasília. }\end{array}$} \\
\hline SUBDIMENSÕES DO ESTUDO & $\begin{array}{l}\text { OBJETIVOS ESPECÍFICOS } \\
\text { DO PRESENTE ESTUDO }\end{array}$ & \begin{tabular}{|c|} 
ROTEIRO DE \\
ENTREVISTA \\
ESTRUTURADA \\
\end{tabular} \\
\hline Ética no ambiente laboral & $\begin{array}{c}\text { Recomendar ações que } \\
\text { contribuam para a educação } \\
\text { ética na Universidade de } \\
\text { Brasília. }\end{array}$ & $\begin{array}{l}\text { QUESTÃO NÚMERO 01: } \\
\text { Busca identificar o que os } \\
\text { respondentes entendem por } \\
\text { ética nas relações } \\
\text { interpessoais em ambiente } \\
\text { laboral. Está associado ao } \\
\text { fato desse estudo contribuir } \\
\text { para a educação ética na } \\
\text { Instituição. }\end{array}$ \\
\hline $\begin{array}{l}\text { Práticas Educativas e Instrumentos } \\
\text { de Gestão da Ética }\end{array}$ & $\begin{array}{l}\text { Enunciar as possibilidades de } \\
\text { implantação de instrumentos de } \\
\text { Gestão da Ética }\end{array}$ & $\begin{array}{l}\text { QUESTÃO NÚMERO 02: } \\
\text { Verifica através dos } \\
\text { respondentes se a } \\
\text { Universidade de Brasília } \\
\text { apoia programas educativos, } \\
\text { para assim enunciar as } \\
\text { possibilidades de implantação } \\
\text { de instrumentos de gestão da } \\
\text { ética por meio da } \\
\text { Andragogia. } \\
\text { QUESTÃO NÚMERO 03 E } \\
\text { 04: } \\
\text { Obter dos entrevistados } \\
\text { sugestões para a difusão da } \\
\text { educação ética na UnB, } \\
\text { mesmo com os impedimentos } \\
\text { citados pelos entrevistados, } \\
\text { como obstáculos ao processo } \\
\text { de trabalho educativo na } \\
\text { Universidade. }\end{array}$ \\
\hline $\begin{array}{l}\text { Gestão da ética em relações de } \\
\text { trabalho }\end{array}$ & $\begin{array}{l}\text { Investigar os aspectos } \\
\text { facilitadores e dificultadores do } \\
\text { processo de trabalho educativo } \\
\text { da Comissão de Ética da UnB. }\end{array}$ & $\begin{array}{l}\text { QUESTÃO NÚMERO 05: } \\
\text { De modo a obter uma } \\
\text { confirmação das sugestões } \\
\text { para a implementação da } \\
\text { educação ética na UnB, por } \\
\text { meio dessa última questão, } \\
\text { obteve-se a coleta dos } \\
\text { aspectos facilitadores e } \\
\text { dificultadores dos trabalhos } \\
\text { educativos da comissão, na } \\
\text { visão de quem trabalha com a } \\
\text { questão disciplinar nar na } \\
\text { Universidade. }\end{array}$ \\
\hline
\end{tabular}

Fonte: Elaborado pela autora, a partir dos dados da pesquisa, 2015. 


\subsubsection{Entrevista Estruturada}

A entrevista foi realizada no dia 20 de maio de 2015, no período da manhã e da tarde, conforme a presença do entrevistado no seu setor de trabalho. As respostas foram coletadas nos dias 21, 22, 25, 26 e 27 de maio de 2015, em hora combinada com o entrevistado e conforme a sua disponibilidade de entrega.

Foram entregues aos respondentes, ainda, o Termo de Consentimento Livre e Esclarecido - TCLE, que contém explicações sobre o tema da pesquisa, além de ser um convite ao entrevistado, para que seja voluntário, em uma pesquisa que tem por objetivo verificar a aplicabilidade dos trabalhos educativos da Comissão de Ética na UnB, sendo que sua aplicação representa também o respeito aos princípios éticos, para a realização deste estudo, quanto à participação dos entrevistados.

Uma vez que o respondente tenha aceitado fazer parte do estudo, ele assinou o TCLE consentindo sua participação na pesquisa, e com a sua assinatura e o número de seu documento pessoal, RG/CPF, declara que foi suficientemente informado sobre as informações do estudo "A Comissão de Ética como Prática Educativa: o Caso da Universidade de Brasília”. Cabe salientar que todos os convites feitos aos servidores presentes foram aceitos.

\subsubsection{Apresentação da Comissão de Ética na UnB, Segundo os Normativos e Como Está Estruturada na Universidade de Brasília}

A Comissão de Ética da UnB atua em consonância com as orientações da Comissão de Ética Pública da Presidência da República - CEP/PR, e tem como objetivo a orientação e o aconselhamento da ética no serviço, não só no que diz respeito às relações de 
trabalho entre os servidores públicos e prestadores de serviço, mas também para com o patrimônio da universidade. A Comissão de Ética funciona como uma instância consultiva de dirigentes e servidores e executa as normas do Código de Ética do Servidor Público Federal.

Quanto à maneira como está composta e organizada, o Regimento Interno da Comissão assim disciplina em seu Capítulo II - Composição e Estrutura Organizacional:

Art. $1^{\circ}$ - A Comissão será composta por três membros titulares e três suplentes, escolhidos entre servidores do quadro permanente de pessoal da Universidade de Brasília, designados pelo Magnífico Reitor, para mandatos de um, dois e três anos.

Art. $2^{\circ}$ - Os membros da Comissão não perceberão remuneração de qualquer natureza pelo exercício da função.

Art. $3^{\circ}$ - A Comissão de Ética conta com uma Secretaria-Executiva, vinculada administrativamente ao Gabinete do Reitor e tecnicamente à Comissão.

Art. $4^{\circ}$ - A Secretaria Executiva será chefiada por um Secretário-Executivo, integrante do quadro permanente de pessoal da Universidade de Brasília, nomeado pelo Magnífico Reitor (UnB, 2008).

Cabe ressaltar que tal regimento está de acordo com o Código de Conduta do Servidor Público Civil do Poder Executivo Federal e com o Decreto n ${ }^{\circ}$. 6.029/2007. Outra informação cabível é que conflitos éticos entre os discentes da UnB não são competência da comissão.

Quanto às normas internas relacionadas à ética na Universidade de Brasília, em vinte e três de Setembro de dois mil e oito, por meio do Ato da Reitoria n $^{\circ} 1.377$ (ANEXO1), o então Reitor pro tempore da UnB, Roberto Armando Ramos de Aguiar, instituiu a Comissão de Ética da Universidade de Brasília, tendo como base o disposto no Decreto ${ }^{\circ}$ 1.171/94, já mencionado anteriormente, sendo esta ação o primeiro cumprimento às normas que regem a gestão ética aplicada na UnB.

O Decreto $\mathrm{n}^{\circ}$ 1.171/94 explicita que o servidor deve primar pela atitude ética, ao dizer, em seu capítulo I, Seção I, Das Regras Deontológicas, Art. I, C, que

a dignidade, o decoro, o zelo, a eficácia e a consciência dos princípios morais são primados maiores que devem nortear o servidor público, seja no exercício do cargo ou função, ou fora dele, já que refletirá o exercício da vocação do próprio poder estatal. Seus atos, comportamentos e atitudes serão direcionados para a preservação da honra e da tradição dos serviços públicos (UNB, 2008). 
Outro cumprimento na Universidade de Brasília foi o Ato da Reitoria nº 1.398 , de primeiro de Agosto de dois mil e oito (ANEXO 2), que criou a Secretaria Executiva da Comissão de Ética, com base no disposto nos parágrafos $1^{\circ}$ e $2^{\circ}$ do artigo $7^{\circ}$ do Decreto $n^{\circ}$ 6.029, de 1/2/2007, já mencionado nesta Disseretaçãon. A Universidade dispõe, também, do Regimento Interno da Comissão de Ética da UnB (ANEXO 3), de 13.11.2008, elaborado a partir da Resolução no 10/2008 da Comissão de Ética Pública da Presidência da República. Essa Resolução, prescreve:

Capitulo I, Das Competências e Atribuições, Art. $2^{\circ}$ Compete às Comissões de Ética: XXV - indicar, por meio de ato interno, representantes locais da Comissão de Ética, que serão designados pelos dirigentes máximos dos órgãos ou entidades, para contribuir nos trabalhos de educação e de comunicação. (UNB, op.cit.) [grifo nosso]

O Regimento Interno da Comissão de Ética tem como finalidade regulamentar as disposições relativas à Comissão de Ética Setorial no âmbito da Universidade de Brasília, de acordo com o Código de Conduta do Servidor Público Civil do Poder Executivo Federal número 1171/94 e do Decreto $n^{\circ}$ 6029/2007, no que se refere à competência, estrutura organizacional, atribuições, deveres e responsabilidades de seus membros, funcionamento e disposições gerais. O decreto reza o seguinte:

Capitulo V - Competências - Art. 10 - Compete à Comissão de Ética, no âmbito da Universidade de Brasília:

II - Atuar como instância consultiva de dirigentes e servidores no âmbito da Universidade de Brasília;

IV - Aconselhar sobre a ética profissional do Servidor Público no trato com pessoas e com o patrimônio público, com vistas ao fortalecimento da ética pública e ao restabelecimento da confiança nas instituições públicas;

VI - Orientar os servidores no sentido de adotar uma conduta conforme os princípios reitores da Administração Pública; inspirando o respeito pelos seus pares e pelo Serviço Público;

XII - propor Acordo de Conduta Pessoal e Profissional.

Do exposto, o Regimento Interno dá sustentação para que a Comissão de Ética da

UnB possa intervir para a resolução de lides. Apresentou-se, aqui, a Comissão de Ética na UnB, segundo a legislação, e como ela se estruturada na UnB, bem como foram descritas as 
atribuições dessa comissão, segundo os normativos, para a gestão ética da Universidade de Brasília.

\subsection{A Construção das Dimensões da Pesquisa}

Inicialmente são apresentados dados de caracterização dos sujeitos extraídos dos formulários que constituem o roteiro de entrevista estruturada, haja vista o que revela Lakatos e Marconi (2003:223) sobre "a delimitação do universo que consiste em explicar que pessoas ou coisas, fenômenos etc. serão pesquisados, enumerando suas características comuns, como, por exemplo, sexo, faixa etária, organização a que pertencem, comunidade onde vivem, etc."

Os departamentos dos servidores públicos envolvidos com a questão disciplinar na UnB foram relatados, e estão sendo reafirmados aqui para facilitar a leitura, são eles: Coordenação de Processo Administrativo Disciplinar - CPAD; Gabinete do Reitor - GRE, Ouvidoria da Universidade de Brasília, também ligada ao GRE; Coordenadoria de Capacitação e Educação - PROCAP, ligada ao Decanato de Gestão de Pessoas - DGP; Serviço de Informação ao Cidadão (SIC), ligada ao GRE e membros da Comissão de Ética da UnB, em que a sua secretaria está localizada no GRE.

No total participaram da entrevista 23 servidores. Os dados referentes às quatro perguntas iniciais do questionário: gênero, idade, tempo de serviço e departamentos da UnB em que estão lotados, foram tratados como caracterização dos sujeitos, e realizou-se aqui o estudo bibliométrico.

Quanto à análise e interpretação dos dados, buscaram-se as orientações de Bardin (1977:37), em relação aos procedimentos para uma análise de conteúdo, que, para a autora, significa, "um conjunto de técnicas de análise das comunicações que visa obter, por 
procedimentos sistemáticos e objetivos de descrição do conteúdo das mensagens, indicadores que permitam a inferência de conhecimentos relativos às condições de produção dessas mensagens.” Em sequência aos passos descritos pela autora, realiza-se a análise categorial ou por categorização:

O critério da categorização pode ser semântico (categorias temáticas: por exemplo, todos os termos que significam a ansiedade, ficam agrupados na categoria "ansiedade", enquanto que os que significam a descontracção, ficam agrupados sob o título conceptual "descontracção", sintático (os verbos, os adjetivos), léxico (classificação de suas palavras segundo o seu sentido, com emparelhamento dos sinônimos e dos sentidos próximos. [...] A categorização é um processo de tipo estruturalista e comporta duas etapas: - O inventário: isolar os elementos; e, - A classificação: repartir os elementos, e portanto, procurar ou impor uma certa organização às mensagens (BARDIN, 1977:117, 118).

Camargo contribui para o entendimento da metodologia aplicada ao explicar que

os passos a serem seguidos para a categorização proposta por Bardin, são assim apresentados:

(1) descrição: enumeração das características do texto, resumida após tratamento analítico; (2) inferência: operação lógica, pela qual se admite uma proposição em virtude da sua ligação com outras proposições já aceitas como verdadeiras (3) interpretação: a significação concedida a estas características; a etapa (2) 'inferência' permite a passagem, explícita e controlada, da etapa 'descrição' para a etapa 'interpretação'. Dessa forma, as iniciativas que a partir de um conjunto de técnicas consistam na explicitação e sistematização do conteúdo das mensagens e da expressão deste conteúdo, pertencem ao domínio da análise de conteúdo. A referida abordagem objetiva efetuar deduções lógicas e justificadas, referentes à origem das mensagens consideradas (BARDIN, 1977 apud CAMARGO, 2015).

Para o cumprimento dos três passos, propostas por Bardin (op.cit.) no primeiro passo referente à ‘descrição' foram feitas exclusões mútuas para alcançar a objetividade da informação, nos dados que apresentaram repetição da informação, em relação às respostas dos entrevistados. Portanto, a categoria inicial obedece a duas triagens que são demonstradas por meio dos quadros elaborados pela autora.

O segundo passo, referente à 'inferência' em que o autor apresenta como sendo a ligação das proposições apresentas com outras reconhecidas como de igual valor, diz respeito ao que é realizado neste trabalho em relação à escolha dos nomes das categorias que irão constituir a segunda triagem da categoria inicial, bem como da categoria intermediária, em 
que a partir dos vocábulos e expressões compostas de um mesmo campo semântico pode-se retirar a unidade de contexto, explica Bardin.

Na hipótese de existir ambiguidades na referenciação do sentido dos elementos codificados, Bardin (1977, p. 37) afirma que para a realização da análise, as unidades de codificação podem ser agrupadas em função de unidades superiores e mais abrangentes, denominadas unidades de contexto, unidades estas que 'permitem compreender a significação dos itens obtidos, repondo-os no seu contexto' (BARDIN, 1977 apud CAMARGO, 2015).

No terceiro e último passo foram escritas as categorias finais de acordo com a fala dos entrevistados, a partir das categorias iniciais e intermediárias, bem como as interpretações que serão feitas das categorias iniciais (primeira e segunda triagem, e das palavras-chaves e expressões compostas das categorias intermediárias) abaixo dos quadros, os quais permitiram uma melhor visualização; a categoria final será uma síntese das respostas das categorias que a precedem.

Desse processo metodológico orientado por Bardin (1977) resultaram duas macro dimensões: legislação e Gestão da Ética, sendo que esta última foi subdividida por três subdimensões assim classificadas: 1) Ética no ambiente laboral; 2) Práticas Educativas e Instrumentos de Gestão Ética Institucional; 3) Gestão da Ética em relações de trabalho. A dimensão legislação é explicada pelas normas descritas nesse estudo e que prescrevem a função educativa da Comissão de Ética. Sendo assim, foi considerada uma macro dimensão, haja vista a obrigatoriedade em atender ao que está prescrito na legislação da Comissão de Ética.

A primeira subdimensão teve por fundamento a primeira questão -1 . O que entende por ética nas relações interpessoais no ambiente laboral? -, e resultou em dez categorias: respeito, boa comunicação, comportamento adequado, compromisso com a instituição, responsabilidade, parâmetros de boa convivência, moral, tolerância, justiça, probidade. 
A segunda subdimensão teve por fundamento a segunda, a terceira e a quarta questões. Questão - 2. Você acha que a universidade apoia programas educativos para os servidores? Em caso positivo, como é dado esse apoio? -, resultando em cinco categorias: desconheço, apoia, concordo parcialmente, ampliação dos programas, apoio de fachada. Questão - 3. Partindo-se da premissa de que a educação ética, de uma forma geral, propicia uma vida melhor para as pessoas, o que você acha que a Comissão de Ética pode fazer para transformar essa expectativa em realidade? Questão 4. Em caso negativo, em que, na sua opinião, seria impossível o desenvolvimento de um trabalho de conscientização da ética na UnB, e quais os motivos que impediriam essa implementação? Para a terceira questão identificaram-se quatro categorias: divulgar o trabalho da Comissão de Ética, investimento da Administração Superior, palestras, seminários. Para a quarta questão, obteve-se três categorias: resistência das pessoas, falta de apoio da Administração Superior, obstáculos a serem vencidos.

A terceira subdimensão tem por fundamento a questão 5 - 5. Em quais aspectos você considera facilitadores e dificultadores do trabalho da Comissão de Ética na UnB? -, obtendo-se daí duas vertentes de categorias: uma sob os aspectos facilitadores com oito categorias: equipe, canais de comunicação, divulgação, ambiente acadêmico, legislação, mediação, reconhecimento, implementação; e uma segunda vertente, sob os aspectos dificultadores, com cinco categorias: falta de apoio da Administração Superior, espaço físico, servidores da UnB, marco regulatório frágil, problemas que dificultam o trabalho em equipe.

\subsection{Estratégia Utilizada Para O Exame Dos Dados}


A partir da compreensão e aplicação da análise categorial de Bardin (1977) é que foram constituídos os quadros aqui apresentados - no subitem 'resultado' -, e dessa maneira utiliza-se a fundamentação teórica abordada neste estudo para explicar as dimensões elencadas; em seguida codificou-se os sujeitos entrevistados pelas letras iniciais: 'M' para o segmento masculino e ' $\mathrm{F}$ ' para o segmento feminino, haja vista todos os entrevistados serem servidores da UnB; a codificação do gênero foi seguida de numeração relativa à ordem do roteiro de entrevista estruturada, da seguinte maneira: M01, F02.

Posteriormente, realizou-se um levantamento de todas as respostas, em que foram recortadas por questões e em seguida agrupadas por subdimensão para melhor leitura, e consequentemente, na melhor interpretação de todo o material coletado. A preparação dos dados permitiu o refinamento do estudo, para a interpretação, bem como facilitou sua visualização, haja vista a disposição organizada visualmente das subdimensões, com as respostas dos entrevistados, das quais foram retiradas as categorias que auxiliaram a análise das subdimensões neste estudo.

Ao desenvolver a metodologia de análise de conteúdo, pesquisou-se em outros textos o desenvolvimento desse método, ou seja, como foi delineado o estudo de caso no trabalho, ao tempo em que foram encontradas as seguintes produções acadêmicas: Silva e Fossá (2015) utilizaram a análise de conteúdo para desenvolver um estudo intitulado 'Exemplo de Aplicação da Técnica para a Análise de Dados Qualitativos'; Wagner (2009) utilizou o método de análise de conteúdo em sua pesquisa intitulada: 'Eu e o Outro' Executivos Expatriados e Itinerantes vivenciando uma nova realidade cultural no âmbito profissional e pessoal"; Pinto (2012) também utilizou o referido método em sua dissertação 'Gestão Universitária e a Política da Informática: o caso de conselho de informática na Universidade'. Por fim, Faria e Alencar (1996) também optaram pelo mesmo método ao produzir o estudo sobre: 'Estímulos e barreiras à criatividade no ambiente de trabalho'. Outro 
estudo que foi pesquisado, quanto a forma de levantar os dados bibliométricos em banco de teses e dissertações, e assim verificar a incidência do tema deste estudo em publicações acadêmicas, da maneira que está sendo tratado nesta pesquisa como uma das obras âncoras, foi a tese de Mendes (2014) intitulada 'A Administração Pública e o Sistema de Gestão da Ética: uma análise da política de promoção da ética no Poder Executivo Federal’.

Esses estudos foram orientadores para a organização e análise dos resultados desta pesquisa, haja vista a procura por delineamentos que melhor demonstrassem à aplicação da técnica de análise de conteúdo, bem como no levantamento das produções acadêmicas, assim como nas citações, aqui utilizadas, as quais foram proeminentes para a elaboração desta Dissertação. A seguir, será apresentado o quadro analítico dessa pesquisa.

\subsection{Quadro Modelo Analítico da Pesquisa}


Quadro 6. Modelo Analítico da Pesquisa

MODELO ANALÍTICO DA PESQUISA

PROBLEMA DA PESQUISA

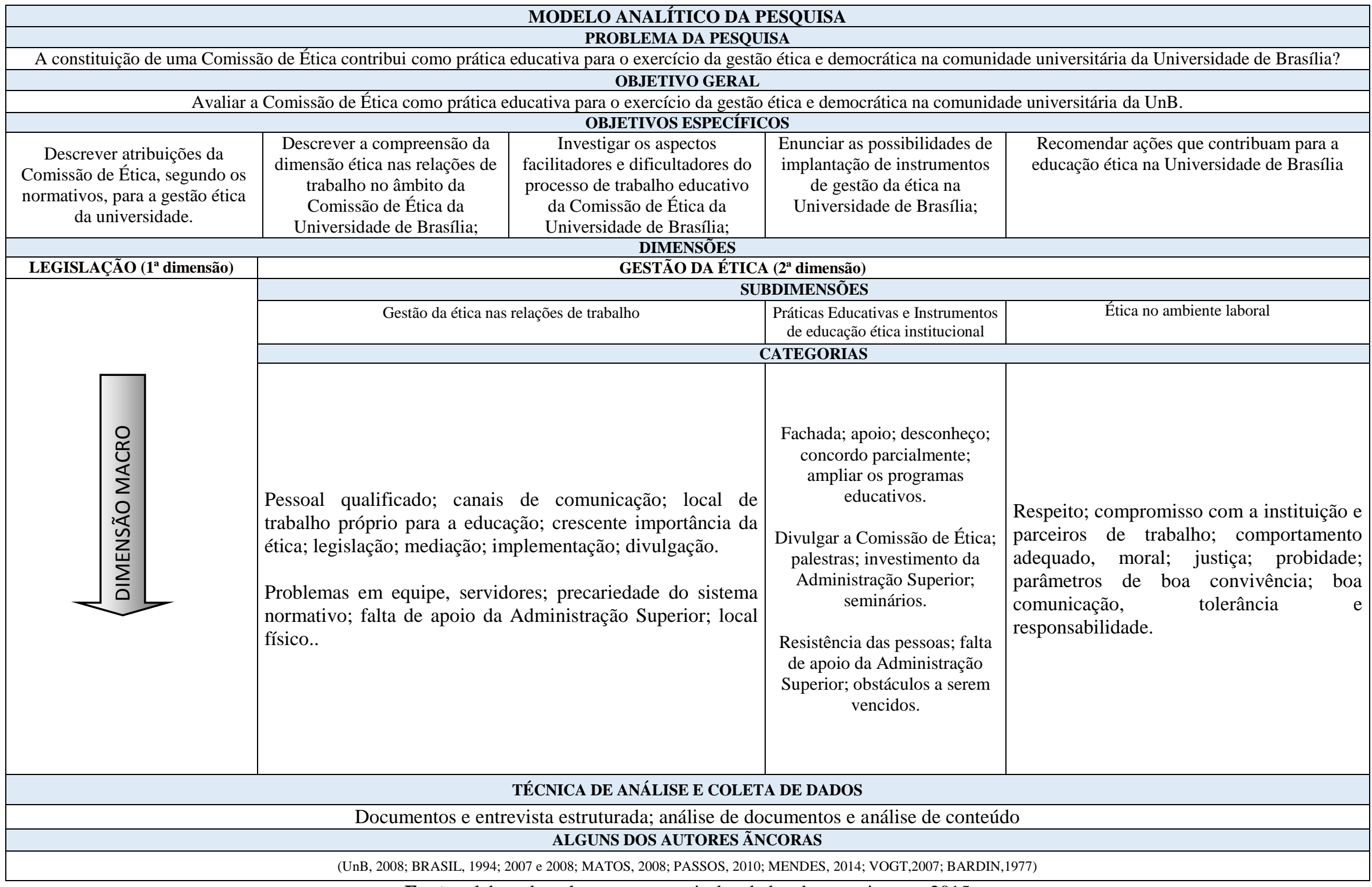

Fonte: elaborado pela autora, a partir dos dados da pesquisa, em 2015 


\subsection{Dificuldades e Limitações da Metodologia}

Existem poucas produções acadêmicas relacionadas ao tema desse estudo, conforme a pesquisa bibliométrica apresentada na Justificativa desta Dissertação. O caráter exploratório da pesquisa comprova dificuldades próprias de um elemento a ser conhecido; assim é por meio do entendimento dos agentes públicos que se almeja compreender o fato (MENDES, 2014).

Do mesmo modo, através das entrevistas, pode-se levantar categorias a posteriori, ou ex post, a partir da coleta dos dados (BARDIN, 1977) que ajudaram a explicar as dimensões deste estudo. Outra constatação vai ao encontro dessa citação: “a dificuldade encontrada para configurar o quadro teórico desse estudo expressa também a necessidade de aprofundar as pesquisas sobre o tema no campo da administração pública inclusive para a formulação de uma teoria ética pública” (MENDES, 2014:226). A subjetividade dos resultados se apresenta como outra limitação da pesquisa, haja vista tratar-se de uma pesquisa qualitativa, em que (Bardin, 1977:9) relata que "a análise de conteúdo oscila entre a objetividade e a subjetividade" [grifo nosso].

Outra limitação está relacionada ao tempo de serviço no setor em que estão lotados alguns dos entrevistados recém-empossados, com tempo mínimo de serviço de 3 dias e máximo de 6 meses, posto que optou-se por entrevistar a população dos setores e não amostras. Quando se trabalha com a população, entrevista-se todos os integrantes de um grupo, ao contrário da amostra. 


\section{RESULTADOS DA PESQUISA}

\subsection{Apresentação das Dimensões e suas Categorias}

Este capítulo apresenta os resultados obtidos a partir de entrevista estruturada, a qual foi aplicada por meio de um roteiro de entrevista a vinte e três servidores públicos da UnB. Este estudo está dividido em duas dimensões: legislação e Gestão da Ética, em que da macro dimensão, Gestão da Ética, foram extraídas três subdimensões. Assim, a primeira parte dos resultados apresenta a subdimensão "Ética no ambiente laboral”. Essa subdimensão foi caracterizada pela primeira pergunta da entrevista estruturada, que buscou identificar o que os respondentes entendem por ética no ambiente laboral; a pergunta está associada ao objetivo especifico: "Recomendar ações que contribuam para a educação ética na Universidade de Brasília", uma vez que, a partir da percepção dos respondentes, possa ser obtido uma conceituação mais clara e objetiva [mais direcionada também ao contexto da realidade existente na Comissão de Ética da Universidade de Brasília] para, então, ser disseminada nas ações educativas que poderão ser desenvolvidas pela Comissão de Ética.

A primeira triagem dos quadros seguintes é composta por fragmentos das respostas dos 23 entrevistados nesta pesquisa, e por apresentarem várias palavras-chaves, em um mesmo fragmento de resposta, poderão aparecer repetidamente nos quadros a seguir, até o isolamento dos padrões repetitivos, e, portanto, a escolha do fragmento mais significativo, o qual irá compor a segunda triagem da categoria inicial, tratada como resultado da categoria inicial. 


\subsubsection{Primeira Subdimensão: Ética no Ambiente Laboral}

A análise da subdimensão 'Ética no ambiente laboral' retratou a resposta à questão ' $\mathrm{O}$ que você entende por ética nas relações interpessoais no ambiente laboral? Justifique'. Foram identificadas 10 categorias: respeito, boa comunicação, comportamento adequado, compromisso com a instituição, responsabilidade, parâmetros de boa convivência, moral, tolerância, justiça e probidade; as quais foram explicadas, conforme as descrições dispostas nos dez quadros que seguem.

\subsubsection{Categoria 'Respeito'}

Esta subdimensão revelou na primeira triagem doze fragmentos, conforme quadro a seguir, em relação a categoria 'respeito'. Todos os fragmentos de resposta da primeira triagem foram codificados por letra e número, em que, por exemplo, 'F' representa o gênero do entrevistado e o número ' 02 ' representa a ordem da entrevista. Nesta primeira análise, 'F02' foi definido por ser o mais representativo.

O método de seleção isolou os padrões repetitivos nos fragmentos codificados por M01, F04, M07, M08, F10, F11, F12, M13, M16, F19 e F23, especificamente, em relação a categoria 'respeito'; em seguida foi feita a escolha pelo fragmento mais representativo, que é F02, em relação à categoria inicial, até a próxima triagem, referente a outra palavra-chave ou expressão composta, conforme demonstra o quadro a seguir. 
Quadro 7. Categoria 'Respeito'

\begin{tabular}{|c|c|}
\hline Categorial Inicial & $\begin{array}{l}\text { Resultado da Categoria } \\
\text { Inicial }\end{array}$ \\
\hline $\begin{array}{l}\text { "[...] respeito com os colegas [...] justiça [...] zelo com o bem público" } \\
(\mathrm{M} 01)\end{array}$ & \multirow{12}{*}{$\begin{array}{l}\text { "[...] comportamento } \\
\text { respeitoso entre colegas de } \\
\text { trabalho }[\ldots] \text { boa comunicação, } \\
\text { discrição }[\ldots] \text { saber viver e } \\
\text { conviver bem num restrito } \\
\text { espaço com diversas culturas" } \\
\text { (F02) }\end{array}$} \\
\hline $\begin{array}{l}\text { "[...] comportamento respeitoso entre colegas de trabalho (...) boa } \\
\text { comunicação, discrição [...] saber viver e conviver bem num restrito espaço } \\
\text { com diversas culturas." (F02) }\end{array}$ & \\
\hline $\begin{array}{l}\text { "[...] respeitar as opiniões dos colegas, observando-se o tom de voz e } \\
\text { expressões que serão utilizadas." (F04) }\end{array}$ & \\
\hline $\begin{array}{l}\text { "[...] respeito, responsabilidade e compromisso com a instituição e parceiros } \\
\text { de trabalho." (M07) }\end{array}$ & \\
\hline $\begin{array}{l}\text { "Relacionar-se [...] respeitosamente não perdendo a dimensão humana nos } \\
\text { processos e princípios da Administração Pública." (M08) }\end{array}$ & \\
\hline $\begin{array}{l}\text { "Respeito nas relações interpessoais [...] respeito às leis [...] e a hierarquia, } \\
\text { trabalho para a instituição e não no interesse pessoal." (F10) }\end{array}$ & \\
\hline $\begin{array}{l}\text { "Atitude respeitosa, transparente [...] diálogo, compreensão das diferenças } \\
\text { de opiniões, maneiras de agir..." (F11) }\end{array}$ & \\
\hline $\begin{array}{l}\text { “[...] forma como se comporta }[\ldots] \text { respeito }[\ldots] \text { dar o melhor de si, ouvir, } \\
\text { responder com clareza e objetividade }[\ldots] \text { ensinar sem humilhar ou ofender } \\
{[\ldots] \text { fazer o bem. Cumprir com deveres funcionais, fazendo sempre o melhor }} \\
\text { que possa e consiga no ambiente de trabalho (F12) }\end{array}$ & \\
\hline $\begin{array}{l}\text { "[...] atitudes positivas }[\ldots] \text { perante os colegas de trabalho }[\ldots] \text { seguir valores } \\
\text { como respeito, ser justo }[. . .] \text { para que o ambiente de trabalho seja um local } \\
\text { adequado e até prazeroso para estar." (M13) }\end{array}$ & \\
\hline $\begin{array}{l}\text { "[...] agir com probidade e respeito às leis [...] atentar aos procedimentos } \\
\text { realizados para adequá-los ao interesse público." (M16) }\end{array}$ & \\
\hline $\begin{array}{l}\text { "[...] relações sociais respeitosas e que não levem os sujeitos a viverem } \\
\text { situações de constrangimento e medo." (F19) }\end{array}$ & \\
\hline $\begin{array}{l}\text { "[...] respeito as relações humanas }[\ldots] \text { baseados nas regras de valor e moral } \\
\text { nas relações de trabalho }(\mathrm{F} 23)\end{array}$ & \\
\hline
\end{tabular}

Fonte: elaborado pela autora, a partir dos dados da pesquisa, em 2015.

Nesse quadro, os entrevistados falam em relação ao campo semântico do vocábulo ‘respeito'. Nessa categoria, eles revelam o que entendem por ética em relações interpessoais 
no ambiente laboral, em que o vocábulo 'respeito está presente repetidamente nos fragmentos de respostas de M01, F02, F04, M07, M08, F10, F11, F12 e M13 da primeira triagem, da categoria inicial. De La Taille (2009:257) afirma que

[...] somente a vivência de relações sociais que se sustentam por relações de reciprocidade e respeito mútuo pode levar os indivíduos a compreender e legitimar tal reciprocidade e tal forma de respeito. Logo, para além de lições de moral que explicam e com as virtudes da justiça, da generosidade, da dignidade, da liberdade, por melhores que sejam, deve imperativamente haver uma 'vida social' na qual tais virtudes regulem as relações interpessoais. [grifo nosso]

Esta citação corrobora com a fala de F02, quando diz que é necessário "saber viver e conviver bem num restrito espaço com diversas culturas.” Inclusive, essa consideração foi escolhida como a fala mais significativa para o resultado, presente na segunda triagem da categoria inicial.

Em relação aos fragmentos encontrados que não apresentaram uma resposta apropriada à pergunta, identificou-se, apenas um fragmento, que é M13, o qual entende que a ética em relações interpessoais se dá com "atitudes positivas perante os colegas de trabalho", como requisito para a ética. Essa resposta deve ser questionada, haja vista a busca de sua definição, posto que esta resposta depende de um referencial, em que a atitude que é positiva para um sujeito, pode não ser positiva para outro.

Outra informação retirada de M13 é que ao "ter atitudes positivas e seguindo valores como respeito e justiça" se alcançará "um local de trabalho adequado e até prazeroso de se estar". Mais uma vez, a afirmação depende do referencial, pois algo pode ser prazeroso e adequado para uma pessoa, mas para outra não, o que relaciona-se com o estudo da motivação, em que Maslow (1954, apud SAMPAIO, 2009:8), conforme visto anteriormente nesta Dissertação, afirma que "o homem é um animal desejante e raramente atinge um estado de completa satisfação, exceto por um curto período de tempo. Assim que um desejo é satisfeito, outro explode e assume o seu lugar". 
Em relação ao fragmento que acrescenta informação aos objetivos deste estudo, F23 aponta para a atenção às "regras de valor e moral nas relações de trabalho", que para a Comissão de Ética, o agir eticamente é justamente a observância aos preceitos do Código de Ética aplicado (Decreto n ${ }^{\mathrm{o}}$ 1.171/94), do Servidor Público Civil do Poder Executivo Federal. É importante salientar que os agentes públicos que trabalham neste Poder também estão abarcados por este código, no que diz respeito ao cometimento de desvios éticos e suas implicações.

\subsubsection{Categoria 'Boa Comunicação'}

Em relação a categoria 'boa comunicação', foram encontrados quatro fragmentos, F02, F04, F11 e F12, dos quais F02 foi selecionado como o mais significativo, conforme pode-se visualizar no quadro a seguir.

\section{Quadro 8. Categoria 'Boa Comunicação'}

\begin{tabular}{|c|c|}
\hline Categorial Inicial & Resultado da Categoria Inicial \\
\hline $\begin{array}{l}\text { “...comportamento respeitoso entre colegas de trabalho(...)boa } \\
\text { comunicação, discrição(...)saber viver e conviver bem num } \\
\text { restrito espaço com diversas culturas.” (F02) }\end{array}$ & \multirow{4}{*}{$\begin{array}{l}\text { “...comportamento respeitoso entre colegas } \\
\text { de trabalho(...)boa comunicação, } \\
\text { discrição(...)saber viver e conviver bem num } \\
\text { restrito espaço com diversas culturas" }(\mathbf{F 0 2})\end{array}$} \\
\hline $\begin{array}{l}\text { "[...] respeitar as opiniões dos colegas, observando-se o tom de } \\
\text { voz e expressões que serão utilizadas." (F04) }\end{array}$ & \\
\hline $\begin{array}{l}\text { "Atitude respeitosa, transparente [...] diálogo, compreensão das } \\
\text { diferenças de opiniões, maneiras de agir..." (F11) }\end{array}$ & \\
\hline $\begin{array}{l}\text { "[...] forma como se comporta }[\ldots] \text { respeito }[\ldots] \text { dar o melhor de } \\
\text { si, ouvir, responder com clareza e objetividade [...] ensinar } \\
\text { sem humilhar ou ofender }[\ldots] \text { fazer o bem. Cumprir com deveres } \\
\text { funcionais, fazendo sempre o melhor que possa e consiga no } \\
\text { ambiente de trabalho }(\mathrm{F} 12)\end{array}$ & \\
\hline
\end{tabular}

Fonte: elaborado pela autora, a partir dos dados da pesquisa, 2015 
A expressão composta 'boa comunicação' é falada diretamente ou através de outras palavras de mesmo valor, ou seja, que estão dentro do mesmo campo semântico, pelos entrevistados, F02, F04, F11 e F12, como sendo um dos requisitos para se agir eticamente. A esse respeito, Silva (2009) revela que a comunicação é "o resgate da compreensão do ser humano como alguém que possui códigos psicossociais (linguísticos) e psicobiológicos (seu comportamento expressão não-verbal) ".

Verifica-se que a boa comunicação não se restringe à expressão verbal, como também ao comportamento não-verbal do falante, o que justifica inclusive a escolha de F02, como a mais significativa por citar 'boa comunicação' e reforçar a ideia de comunicação ao citar outro vocábulo, que no caso é ‘comportamento'.

F12 acrescenta uma importante informação, quando diz "[...] ensinar sem humilhar ou ofender [...] fazer o bem”. A este respeito, Azevedo et al., (2012:136) diz que “expressar-se com a intenção de oprimir, humilhar ou ofender alguém repetidas vezes é bullying”. Logo, além de ser falta de ética, constitui também prática criminosa.

\subsubsection{Categoria 'Comportamento Adequado'}

Quanto à categoria 'comportamento adequado', identificada em cinco fragmentos de respostas, F02, F03, F11, F12, F18, o mais representativo foi F03, conforme observa-se no Quadro 9. 
Quadro 9. Categoria 'Comportamento Adequado'

\begin{tabular}{|c|c|}
\hline Categorial Inicial & Resultado da Categoria Inicial \\
\hline $\begin{array}{l}\text { "[...] comportamento respeitoso entre colegas de trabalho }[. . .] \text { boa } \\
\text { comunicação, discrição }[. . .] \text { saber viver e conviver bem num restrito } \\
\text { espaço com diversas culturas." (F02) }\end{array}$ & \multirow{5}{*}{$\begin{array}{l}\text { "[...] postura considerada adequada } \\
\text { pelos membros de uma comunidade, } \\
\text { maioria dos servidores, técnicos, } \\
\text { docentes e discentes." (F03) }\end{array}$} \\
\hline $\begin{array}{l}\text { "[...] postura considerada adequada pelos membros de uma } \\
\text { comunidade, maioria dos servidores, técnicos, docentes e } \\
\text { discentes.”(F03) }\end{array}$ & \\
\hline $\begin{array}{l}\text { "Atitude respeitosa, transparente [...] diálogo, compreensão das } \\
\text { diferenças de opiniões, maneiras de agir...” (F11) }\end{array}$ & \\
\hline $\begin{array}{l}\text { "[...] forma como se comporta }[\ldots] \text { respeito }[\ldots] \text { dar o melhor de si, } \\
\text { ouvir, responder com clareza e objetividade }[\ldots] \text { ensinar sem humilhar } \\
\text { ou ofender }[\ldots] \text { fazer o bem. Cumprir com deveres funcionais, fazendo } \\
\text { sempre o melhor que possa e consiga no ambiente de trabalho }(\mathrm{F} 12)\end{array}$ & \\
\hline $\begin{array}{l}\text { “[...] conduta positiva }[. . .] \text { em relação aos colegas de trabalho para } \\
\text { que o ambiente seja de harmonia e paz }[\ldots] \text { e resultado do trabalho } \\
\text { mais produtivo (F18) }\end{array}$ & \\
\hline
\end{tabular}

Fonte: elaborado pela autora, a partir dos dados da pesquisa em 2015

Quanto à categoria 'comportamento adequado', os entrevistados F02, F03, F11, F12, F18, na primeira triagem de categoria inicial, falam sobre o 'comportamento', embora tenha sido referido também no quadro anterior, por estar dentro do campo semântico de 'boa comunicação', justamente por acrescentar a informação de 'adequado', e a de que seria o adequado. Na visão de Vasquez,

a ética é a teoria ou ciência do comportamento moral dos homens em sociedade. Ou seja, é a ciência de uma forma específica de comportamento humano, assim o ético transforma-se [...] numa espécie de legislador do comportamento moral dos indivíduos ou da comunidade. [...] Desta maneira temos, pois, de um lado, atos e formas de comportamento dos homens em face de determinados problemas, que chamamos morais, e, do outro lado, juízos que aprovam ou desaprovam moralmente os mesmos atos. Mas, por sua vez, tanto os atos quanto os juízos morais pressupõem certas normas que apontam o que se deve fazer (VÁSQUEZ, 1992:1, 3, 5). 
Depreende-se que o 'comportamento adequado' é aquele que já foi ditado ou normatizado por um grupo em que o indivíduo está inserido. Esse entendimento é ratificado pela resposta codificada por F03, escolhido como a fala mais significativa, a qual está na segunda triagem, como resultado da categoria inicial e que irá compor o quadro final.

\subsubsection{Categoria 'Compromisso com a Instituição'}

‘Compromisso com a Instituição' apareceu em dois fragmentos, M07 e F12, sendo o mais representativo, o M07, conforme quadro a seguir.

Quadro 10. Categoria 'Compromisso com a instituição'

\begin{tabular}{|c|c|}
\hline Categorial Inicial & $\begin{array}{c}\text { Resultado da } \\
\text { Categoria Inicial }\end{array}$ \\
\hline $\begin{array}{l}\text { "[...] respeito, responsabilidade e compromisso com a instituição e } \\
\text { parceiros de trabalho". (M07) }\end{array}$ & \multirow{2}{*}{$\begin{array}{c}\text { “[...] respeito, responsabilidade e } \\
\text { compromisso com a instituição e } \\
\text { parceiros de trabalho". (M07) }\end{array}$} \\
\hline $\begin{array}{l}\text { "[...] forma como se comporta }[\ldots] \text { respeito }[\ldots] \text { dar o melhor de si, ouvir, } \\
\text { responder com clareza e objetividade }[\ldots] \text { ensinar sem humilhar ou ofender } \\
{[\ldots] \text { fazer o bem. Cumprir com deveres funcionais, fazendo sempre o }} \\
\text { melhor que possa e consiga no ambiente de trabalho (F12) }\end{array}$ & \\
\hline
\end{tabular}

Fonte: elaborado pela autora, a partir dos dados da pesquisa em 2015

Os entrevistados, M07 e F12, revelaram que a categoria 'compromisso com a Instituição’ significa ter ética nas relações interpessoais no ambiente laboral, ao passo que M07 acrescenta que esse compromisso deve ocorrer também com 'parceiros de trabalho', completando a resposta, dada as seguintes palavras da questão: 'ética nas relações interpessoais'. Costa diz que 
o relacionamento interpessoal - necessidade social, conforme Maslow (2000), ou fator higiênico, segundo a teoria herzbergiana - deve se pautar pelo diálogo, sem o qual, as relações entre os indivíduos resvalam para conflitos vários. A dignidade jamais deve ser esquecida ou colocada em segundo plano. A prática da humanização deve ser observada ininterruptamente. O comportamento ético deve ser o princípio de vida da organização, uma vez que ser ético é preocupar-se com a felicidade pessoal e coletiva (COSTA, 2003:1).

Compreende-se que é vital saber relacionar-se, e que o diálogo deve ser a 'via de regra' para a manutenção de bons relacionamentos e o alcance de uma humanização. O ‘compromisso com a instituição' é uma atitude ética, haja vista ser o local de onde se retira o sustento diário, necessário à vida. O ambiente laboral é aquele em que a maioria das pessoas passam grande parte do dia, às vezes, até mais tempo do que com a própria família.

\subsubsection{Categoria 'Responsabilidade'}

'Responsabilidade' também apareceu em dois fragmentos de resposta, nas falas de F09 e M07, sendo o mais representativo F09, conforme quadro a seguir.

Quadro 11. Categoria 'Responsabilidade'

\begin{tabular}{|c|c|}
\hline Categorial Inicial & Resultado da Categoria Inicial \\
\hline $\begin{array}{l}\text { "[...] conduta responsável }[\ldots] \text { agir de forma } \\
\text { sociavelmente aceita sem prejudicar os outros, buscando } \\
\text { integridade e harmonia das relações". (F09) }\end{array}$ & \multirow{2}{*}{$\begin{array}{l}\text { "[...] conduta responsável }[\ldots] \text { agir de forma } \\
\text { sociavelmente aceita sem prejudicar os outros, } \\
\text { buscando integridade e harmonia das relações". (F09) }\end{array}$} \\
\hline $\begin{array}{l}\text { "[...] respeito, responsabilidade e compromisso com a } \\
\text { instituição e parceiros de trabalho". (M07) }\end{array}$ & \\
\hline
\end{tabular}

Fonte: elaborado pela autora, a partir dos dados da pesquisa em 2015 
Para F09 e M07, agir com 'responsabilidade' é ter uma atitude ética em relacionamento interpessoal no ambiente laboral. Em relação a esse vocábulo, Vásquez $(1992: 2,3)$ revela que

o problema da essência do ato moral envia a outro problema importantíssimo: o da responsabilidade. É possível falar em comportamento moral somente quando o sujeito que assim se comporta é responsável pelos seus atos, mas isto, por sua vez envolve o pressuposto de que pôde fazer o que queria fazer, ou seja, de que pôde escolher entre duas ou mais alternativas e agir de acordo com a decisão tomada. $\mathrm{O}$ problema da liberdade da vontade, por isso, é inseparável do da responsabilidade.

Verifica-se que ter responsabilidade e ter a ciência que determinada ação terá uma consequência, e que ela incidirá diretamente em uma responsabilização. Logo, a conduta deve ser responsável, conforme a fala de F09.

\subsubsection{Categoria 'Parâmetros de Boa Convivência'}

'Parâmetros de boa convivência' apareceu como uma unidade maior que agrupa as outras palavras grifadas, por pertencerem ao mesmo campo semântico, em quatro fragmentos de respostas, as saber, F12, M13, M14, F17, sendo o mais representativo F17, conforme o quadro a seguir. 


\section{Quadro 12. Categoria 'Parâmetros de Boa Convivência'}

\begin{tabular}{|c|c|}
\hline Categorial Inicial & $\begin{array}{c}\text { Resultado da } \\
\text { Categoria Inicial }\end{array}$ \\
\hline $\begin{array}{l}\text { "[...] forma como se comporta [...] respeito [...] dar o melhor } \\
\text { de si, ouvir, responder com clareza e objetividade [...] ensinar } \\
\text { sem humilhar ou ofender [...] fazer o bem. Cumprir com } \\
\text { deveres funcionais, fazendo sempre o melhor que possa e } \\
\text { consiga no ambiente de trabalho". (F12) }\end{array}$ & \multirow{4}{*}{$\begin{array}{l}\text { “[...] trabalhar dentro de um padrão probo, } \\
\text { moral, em todas relações estabelecidas [...] há } \\
\text { alguns parâmetros de boa convivência que são } \\
\text { de abrangência maior e podem direcionar tais } \\
\text { relações”. (F17) }\end{array}$} \\
\hline $\begin{array}{l}\text { “....atitudes positivas }[\ldots] \text { perante os colegas de trabalho [...] } \\
\text { seguir valores como respeito, ser justo [...] para que o } \\
\text { ambiente de trabalho seja um local adequado e até prazeroso } \\
\text { para estar". (M13) }\end{array}$ & \\
\hline $\begin{array}{l}\text { "[...] atos com vista ao bom e o justo, sempre evitando a } \\
\text { maldade e a injustiça com seus colegas de trabalho". (M14) }\end{array}$ & \\
\hline $\begin{array}{l}\text { "[...] trabalhar dentro de um padrão probo, moral, em todas } \\
\text { relações estabelecidas [...] há alguns parâmetros de boa } \\
\text { convivência que são de abrangência maior e podem direcionar } \\
\text { tais relações". (F17) }\end{array}$ & \\
\hline
\end{tabular}

Fonte: elaborado pela autora, a partir dos dados da pesquisa em 2015

Pode-se verificar que os entrevistados F12, M13, M14, F17 entendem que para perpetrar a ética em relações interpessoais no ambiente laboral deve-se atentar para a prática de atos bons de acordo com parâmetros de boa convivência. Sobre isso, Vásquez (1992:3) defende que

as respostas sobre o que é bom variam, evidentemente, de uma teoria para a outra: para uns, o bom é a felicidade ou o prazer, para outros, o útil, o poder, a autocriação do ser humano, etc. Mas, justamente com este problema central, colocam-se também outros problemas éticos fundamentais, tais como o de definir a essência ou os traços essenciais do comportamento moral à diferença de outras formas de comportamento humano, como a religião, a política, o direito, a atividade científica, a arte, o trato social, etc.

Verifica-se que, para que haja uma definição da essência de um comportamento moral, é necessário saber quais são os parâmetros de boa convivência que devem nortear um comportamento ético, haja vista a compreensão do que é ‘bom’ ser diferente entre os sujeitos, 
conforme revela Vásquez (1992). Os parâmetros que F17 diz ser "de abrangência maior que podem direcionar tais relações" corroboram com a fala de Vásquez, e por esse motivo é que foi escolhida como a mais significativa para compor o quadro da segunda triagem, resultado das Categorias Iniciais.

\subsubsection{Categoria 'Moral'}

A categoria 'moral' apareceu em quatro fragmentos: F06, M15, F17 e M20, sendo que o mais representativo foi M20, conforme quadro a seguir.

Quadro 13. Categoria 'Moral'

\begin{tabular}{|c|c|}
\hline Categorial Inicial & $\begin{array}{c}\text { Resultado da } \\
\text { Categoria Inicial }\end{array}$ \\
\hline $\begin{array}{l}\text { "[...] transparência, coerência }[\ldots] \text { de acordo com } \\
\text { princípios morais com colegas...". (F06) }\end{array}$ & \multirow{4}{*}{$\begin{array}{l}\text { "[...] conjunto de regras morais que se } \\
\text { estabeleceram socialmente [...] preocupação com o } \\
\text { outro e o entendimento de que somos seres } \\
\text { sensivelmente interdependentes nas nossas relações } \\
{[\ldots] \text { controle individual dos ímpetos naturais. [...] olhar }} \\
\text { generoso e de um altruísmo espontâneo sem } \\
\text { expectativa de receber nada em troca [...] tolerância e } \\
\text { paciência. Essas atitudes de relativização [...] } \\
\text { minimizam a brutalidade da vida". (M20) }\end{array}$} \\
\hline $\begin{array}{l}\text { "Tratar com urbanidade, imparcialidade, moralidade e } \\
\text { legalidade as pessoas [...]". (M15) }\end{array}$ & \\
\hline $\begin{array}{l}\text { "[...] trabalhar dentro de um padrão probo, moral, em } \\
\text { todas relações estabelecidas [...] há alguns parâmetros } \\
\text { de boa convivência que são de abrangência maior e } \\
\text { podem direcionar tais relações". (F17) }\end{array}$ & \\
\hline $\begin{array}{l}\text { "[...] conjunto de regras morais que se estabeleceram } \\
\text { socialmente [...] preocupação com o outro e o } \\
\text { entendimento de que somos seres sensivelmente } \\
\text { interdependentes nas nossas relações [...] controle } \\
\text { individual dos ímpetos naturais. [...] olhar generoso e } \\
\text { de um altruísmo espontâneo sem expectativa de } \\
\text { receber nada em troca [...] tolerância e paciência. Essas } \\
\text { atitudes de relativização [...] minimizam a brutalidade } \\
\text { da vida". (M20) }\end{array}$ & \\
\hline
\end{tabular}

Fonte: elaborado pela autora, a partir dos dados da pesquisa em 2015 
Os entrevistados F06, M15, F17 e M20 relatam que agir de acordo com a moral é praticar a ética em relações interpessoais. Para corroborar esse entendimento, Vásquez revela que

[...] moral vem do latim mos ou mores, "costume" ou "costumes", no sentido de conjunto de normas ou regras adquiridas por hábito. A moral se refere, assim, ao comportamento adquirido ou modo de ser conquistado pelo homem" (VÁSQUEZ, 1992:5).

Esta citação reforça, então, o entendimento expresso por M20, quando afirma ser o "[...] conjunto de regras morais que se estabeleceram socialmente"; embora aqui o entrevistado tenha usado a palavra 'socialmente', enquanto o 'hábito' da citação apresente sinônimo de costume e tradição, o que retoma às palavras ditas pelo entrevistado "que se estabeleceram socialmente". Por isso, essa resposta foi escolhida como a mais significativa.

Quando M20 relata a 'preocupação com o outro e o entendimento de que somos seres sensivelmente interdependentes nas nossas relações', ele também está se referindo à prática da ética nas relações interpessoais, uma vez que o entendimento de que 'somos seres sensivelmente interdependentes nas nossas relações' possa provocar sentimentos de respeito e tolerância que são fundamentais para o agir eticamente. Ainda em relação ao que Vásquez considera sobre o homem e a moral, temos que

os homens não só agem moralmente (isto é, enfrentam determinados problemas nas suas relações mútuas, tomam decisões e realizam certos atos para resolvê-los e, ao mesmo tempo, julgam ou avaliam de uma ou de outra maneira estas decisões e estes atos), mas também refletem sobre esse comportamento prático e o tomam como objeto da sua reflexão e do seu pensamento (VÁSQUEZ, op.cit.:02).

A compreensão é de que o homem que age moralmente reflete sobre as suas ações, e age eticamente, inclusive, no ambiente de trabalho. 


\subsubsection{Categoria 'Tolerância'}

Os vocábulos sinônimos 'tolerância' e 'paciência' e outros de mesmo núcleo semântico apareceram em cinco fragmentos, F12, F11, F09, F05 e M20, dos quais M20 é o mais representativo, conforme quadro a seguir.

Quadro 14. Categoria 'Tolerância'

\begin{tabular}{|c|c|}
\hline Categorial Inicial & $\begin{array}{c}\text { Resultado da } \\
\text { Categoria Inicial }\end{array}$ \\
\hline $\begin{array}{l}\text { "[...] tratar os colegas com urbanidade e dentro dos } \\
\text { padrões éticos institucionais". (F05) }\end{array}$ & \multirow{5}{*}{$\begin{array}{l}\text { "[...] conjunto de regras morais que se estabeleceram } \\
\text { socialmente [...] preocupação com o outro e o } \\
\text { entendimento de que somos seres sensivelmente } \\
\text { interdependentes nas nossas relações [...] controle } \\
\text { individual dos ímpetos naturais. [...] olhar generoso e } \\
\text { de um altruísmo espontâneo sem expectativa de } \\
\text { receber nada em troca [...] tolerância e paciência. } \\
\text { Essas atitudes de relativização [...] minimizam a } \\
\text { brutalidade da vida". (M20) }\end{array}$} \\
\hline $\begin{array}{l}\text { "[...] conduta responsável }[\ldots] \text { agir de forma } \\
\text { sociavelmente aceita sem prejudicar os outros, } \\
\text { buscando integridade e harmonia das relações". (F09) }\end{array}$ & \\
\hline $\begin{array}{l}\text { "Atitude respeitosa, transparente }[\ldots] \text { diálogo, } \\
\text { compreensão das diferenças de opiniões, maneiras de } \\
\text { agir...". (F11) }\end{array}$ & \\
\hline $\begin{array}{l}\text { "[...] forma como se comporta[...] respeito [...] dar o } \\
\text { melhor de si, ouvir, responder com clareza e } \\
\text { objetividade }[\ldots] \text { ensinar sem humilhar ou ofender }[\ldots] \\
\text { fazer o bem. Cumprir com deveres funcionais, fazendo } \\
\text { sempre o melhor que possa e consiga no ambiente de } \\
\text { trabalho". (F12) }\end{array}$ & \\
\hline $\begin{array}{l}\text { "[...] conjunto de regras morais que se estabeleceram } \\
\text { socialmente [...] preocupação com o outro e o } \\
\text { entendimento de que somos seres sensivelmente } \\
\text { interdependentes nas nossas relações [...] controle } \\
\text { individual dos ímpetos naturais. [...] olhar generoso e } \\
\text { de um altruísmo espontâneo sem expectativa de } \\
\text { receber nada em troca }[. . .] \text { tolerância e paciência. } \\
\text { Essas atitudes de relativização [...] minimizam a } \\
\text { brutalidade da vida". (M20) }\end{array}$ & \\
\hline
\end{tabular}

Fonte: elaborado pela autora, a partir dos dados da pesquisa em 2015 
Para os entrevistados F12, F11, F09, F05 e M20 agir com tolerância - palavra escolhida como uma unidade de significado maior para abarcar os outros vocábulos falados, tais como urbanidade, harmonia, compreensão, ouvir, paciência - é agir de maneira ética, em uma relação interpessoal no ambiente laboral. Em relação à prática da tolerância, de modo a alcançar a atitude ética, Lopes (2004:3) assim afirma que

a prática da tolerância deve começar em cada um de nós, com um exercício de coragem ao encarar as nossas limitações e assumir por elas a responsabilidade, sem nos culparmos. Sendo tolerantes com os nossos próprios defeitos, e animados pelo sincero propósito de nos modificarmos, começamos lentamente a compreender que os outros também merecem essa tolerância e essa compreensão que dedicamos a nós mesmos e que, por isso mesmo, sabemos ser suave e curativa como um bálsamo. E somente assim, depois de mobilizarmos a paz dentro de nós, podemos dedicar-nos a compartilhá-la com os outros.

Verifica-se que tal atitude deve ser intrínseca ao homem que é ético em suas relações. A prática da tolerância deve começar com o próprio ser, para assim ser praticada com os demais. De acordo com o entrevistado M20, “essas atitudes de relativização [...] minimizam a brutalidade da vida”.

\subsubsection{Categoria 'Justiça'}

A categoria 'justiça' revelou-se em três fragmentos: M01, M13 e M14, dos quais o mais representativo foi M14, conforme quadro a seguir. 
Quadro 15. Categoria 'Justiça'

\begin{tabular}{|c|c|}
\hline Categorial Inicial & $\begin{array}{l}\text { Resultado da } \\
\text { Categoria Inicial }\end{array}$ \\
\hline $\begin{array}{l}\text { "[...] respeito com os colegas }[\ldots] \text { justiça }[\ldots] \text { zelo com o bem } \\
\text { público". (M01) }\end{array}$ & \multirow{3}{*}{$\begin{array}{l}\text { "[...] atos com vista ao bom e o justo, } \\
\text { sempre evitando a maldade e a injustiça } \\
\text { com seus colegas de trabalho". (M14) }\end{array}$} \\
\hline $\begin{array}{l}\text { "[...] atitudes positivas }[\ldots] \text { perante os colegas de trabalho }[\ldots] \\
\text { seguir valores como respeito, ser justo }[\ldots] \text { para que o ambiente de } \\
\text { trabalho seja um local adequado e até prazeroso para estar". (M13) }\end{array}$ & \\
\hline $\begin{array}{l}\text { "[...] atos com vista ao bom e o justo, sempre evitando a maldade e } \\
\text { a injustiça com seus colegas de trabalho". (M14) }\end{array}$ & \\
\hline
\end{tabular}

Fonte: elaborado pela autora, a partir dos dados da pesquisa em 2015

Os entrevistados M01, M13 e M14 entendem que a justiça é necessária para o agir ético em relações interpessoais no ambiente laboral. Vaz (2011:445), em relação à justiça, revela que, “como hábito, porém, o ethos regido pelo critério do justo é a virtude, ou bem do indivíduo que se submete à norma da reta razão (orthos logos). Eis porque a justiça é a mais alta das virtudes na esfera do agir ético [...]”. Dessa forma, verifica-se o grau de importância da justiça para o agir ético, o que corrobora com o que diz a ética aristotélica quando "propõe a superação do conflito pela prática das virtudes morais” (CALURI, 2011:72).

Caluri (op.cit.:72, 73) também afirma que "viver com ética é viver em conformidade com a justiça. [...] A justiça é o centro da reflexão ética”.

\subsubsection{Categoria 'Probidade'}

A categoria 'Probidade' aparece em dois fragmentos, M16 e F17, dos quais o mais representativo foi M16, conforme quadro a seguir. 
Quadro 16. Categoria 'Probidade'

\begin{tabular}{|c|c|}
\hline Categorial Inicial & $\begin{array}{l}\text { Resultado da } \\
\text { Categoria Inicial }\end{array}$ \\
\hline $\begin{array}{l}\text { "[...] agir com probidade e respeito às leis }[\ldots] \text { atentar aos } \\
\text { procedimentos realizados para adequá-los ao interesse público". } \\
\text { (M16) }\end{array}$ & "[...] agir com probidade e respeito às leis \\
\hline $\begin{array}{l}\text { "[...] trabalhar dentro de um padrão probo, moral, em todas } \\
\text { relações estabelecidas [...] há alguns parâmetros de boa } \\
\text { convivência que são de abrangência maior e podem direcionar } \\
\text { tais relações". (F17) }\end{array}$ & $\begin{array}{l}\text { [...] atentar aos procedimentos realizados para } \\
\text { adequá-los ao interesse público". (M16) }\end{array}$ \\
\hline
\end{tabular}

Fonte: elaborado pela autora, a partir dos dados da pesquisa em 2015

Os dois entrevistados M16 e F17 falaram sobre a categoria 'probidade', como requisito para o agir ético. Em relação a esse vocábulo, Caluri (2011:74) revela que "dentre vários requisitos do profissional ético, podemos destacar os mais importantes: a lealdade, a moderação e a probidade". Assim, verifica-se que a probidade é um requisito essencial ao profissional que deseja ser ético.

'Padrões Éticos Institucionais', ‘integridade' e 'discrição', por apresentarem apenas uma ocorrência, foram eliminados do quadro da segunda triagem das categorias iniciais, por não apresentarem repetição nas respostas dos entrevistados. Com a eliminação dos padrões repetitivos que ocorreu em razão de palavras-chave ou expressões compostas, as categorias iniciais, aqui elencadas, foram encaminhadas para a categoria intermediária, através de um processo de aglutinação, que facilitou a criação do quadro das categorias intermediárias, bem como o das categorias finais. Todo este processo foi feito com base nas orientações de Bardin (1977) sobre a análise categorial. Cabe salientar que a sustentação para as inferências foram os autores abordados no referencial teórico da presente pesquisa. 


\subsubsection{Análise da Subdimensão}

\section{Quadro 17. Quadro Geral da Primeira Subdimensão}

\begin{tabular}{|c|c|c|c|}
\hline $\begin{array}{l}\text { Subdimensão de } \\
\text { Estudo }\end{array}$ & $\begin{array}{c}\text { Categorias Iniciais } \\
\text { Trechos e Expressões Compostas em Negrito }\end{array}$ & $\begin{array}{c}\text { Categorias } \\
\text { Intermediárias }\end{array}$ & Categorias Finais \\
\hline \multirow{8}{*}{$\begin{array}{l}\text { Ética no ambiente } \\
\text { laboral (MATOS, } \\
\text { 2008; PASSOS, } \\
\text { 2010; e BITTAR, } \\
\text { 2010.) }\end{array}$} & $\begin{array}{l}\text { "...comportamento respeitoso entre colegas de } \\
\text { trabalho [...] boa comunicação, discrição [...] } \\
\text { saber viver e conviver bem num restrito espaço } \\
\text { com diversas culturas" (F02) }\end{array}$ & $\begin{array}{l}\text { Respeito; } \\
\text { Boa } \\
\text { comunicação; }\end{array}$ & \multirow{8}{*}{$\begin{array}{l}\text { O entendimento por } \\
\text { ética no ambiente } \\
\text { laboral, ocorre ao } \\
\text { agir com respeito e } \\
\text { compromisso com a } \\
\text { instituição e } \\
\text { parceiros de } \\
\text { trabalho. Tendo um } \\
\text { comportamento } \\
\text { considerado } \\
\text { adequado, moral; ao } \\
\text { agir com justiça e } \\
\text { probidade, bem } \\
\text { como atentar para os } \\
\text { parâmetros de boa } \\
\text { convivência: como a } \\
\text { boa comunicação, a } \\
\text { tolerância e a } \\
\text { responsabilidade. }\end{array}$} \\
\hline & $\begin{array}{l}\text { "[...] postura considerada adequada pelos } \\
\text { membros de uma comunidade, maioria dos } \\
\text { servidores, técnicos, docentes e discentes" (F03) }\end{array}$ & $\begin{array}{l}\text { Comportamento } \\
\text { adequado }\end{array}$ & \\
\hline & $\begin{array}{l}\text { "[...] respeito, responsabilidade e } \\
\text { compromisso com a instituição e parceiros de } \\
\text { trabalho" (M07) }\end{array}$ & $\begin{array}{l}\text { Responsabilidad } \\
\text { e; Compromisso } \\
\text { com a } \\
\text { Instituição e } \\
\text { parceiros de } \\
\text { trabalho; }\end{array}$ & \\
\hline & $\begin{array}{l}\text { "[...] conduta responsável }[\ldots] \text { agir de forma } \\
\text { sociavelmente aceita sem prejudicar os outros..." } \\
(\mathrm{F} 09)\end{array}$ & & \\
\hline & $\begin{array}{l}\text { "[...] atos com vista ao bom e o justo, sempre } \\
\text { evitando a maldade e a injustiça com seus } \\
\text { colegas de trabalho" (M14) }\end{array}$ & Justiça; & \\
\hline & $\begin{array}{l}\text { "[...] trabalhar dentro de um padrão probo, } \\
\text { moral, em todas relações estabelecidas [...] há } \\
\text { alguns parâmetros de boa convivência que são } \\
\text { de abrangência maior e podem direcionar tais } \\
\text { relações." (F17) }\end{array}$ & $\begin{array}{l}\text { Parâmetros de } \\
\text { boa convivência }\end{array}$ & \\
\hline & $\begin{array}{l}\text { "[...] agir com probidade e respeito às leis } \\
{[\ldots] . "(\mathrm{M} 16)}\end{array}$ & Probidade & \\
\hline & $\begin{array}{l}\text { “...conjunto de regras morais que se } \\
\text { estabeleceram socialmente }[\ldots] \text { preocupação } \\
\text { com o outro e o entendimento de que somos } \\
\text { seres sensivelmente interdependentes nas nossas } \\
\text { relações [...] controle individual dos ímpetos } \\
\text { naturais. [...] olhar generoso e de um altruísmo } \\
\text { espontâneo sem expectativa de receber nada em } \\
\text { troca }[. . .] \text { tolerância e paciência. Essas atitudes } \\
\text { de relativização [...] minimizam a brutalidade da } \\
\text { vida." (M20) }\end{array}$ & $\begin{array}{l}\text { Moral; } \\
\text { Tolerância }\end{array}$ & \\
\hline
\end{tabular}

Fonte: elaborado pela autora, a partir dos dados da pesquisa em 2015 
Após analisar e interpretar os fragmentos de fala de todos os entrevistados, por meio da interpretação por palavras-chave ou expressões compostas, categorias iniciais, foram estabelecidas as intermediárias. A interpretação foi realizada com base no referencial bibliográfico deste trabalho, o que dá respaldo teórico à pesquisa. A categoria final resultou-se das categorias anteriores, constituindo uma síntese das ideias apresentadas pelos entrevistados, e assim escrita de forma coerente e coesa para o entendimento geral. É importante salientar que a análise dessas categorias ajuda a compreender a dimensão aqui tratada.

De acordo com os autores Matos, 2008; Passos, 2010; e Bittar, 2010, esta dimensão, numa perspectiva da ética, revela que não há possibilidade de vida social sem que haja observância de princípios éticos. A importância desse regramento é vital e se dá à medida em que os valores morais vão sendo passados de pai para filho, de geração em geração.

Para a manutenção de bons comportamentos necessários à sociedade é que estes valores funcionam como elementos capazes de regular o comportamento das pessoas (PASSOS, 2010). Esses comportamentos são necessários para o bom convívio em qualquer relacionamento, seja ele profissional, familiar e etc.

Passos (2010:21) também revela que a "exigência de valores morais em todas as instâncias sociais surge no mesmo momento em que a sociedade passa por uma grande crise de valores". Logo, a falta de respeito e de limites pelo outro ocasiona ruptura nas relações interpessoais, posto que somente a postura equilibrada poderá estabelecer "a equitativa sensação do justo meio nos interesses sociais, institucionais, privados e públicos, individuais e coletivos" (BITTAR, 2010:132).

É necessário que o indivíduo conheça os princípios éticos norteadores do bom convívio em sociedade e que faça contínuas reflexões éticas, de modo a tomar melhores 
decisões as quais acarretarão os melhores resultados, haja vista a diminuição ou até mesmo a prevenção de erros (PASSOS, 2010). Portanto, a subdimensão ética no ambiente laboral desvela o entendimento dos entrevistados, os quais foram corroborados com os autores da fundamentação teórica deste trabalho: a ética nas relações profissionais, pode ser garantia de respeito a direitos básicos dos empregados, tais como: receber informações, poder reunir-se ou falar livremente" (PASSOS, op.cit.:100). Essa garantia não só se revela na hierarquia profissional, mas também para com os pares em um relacionamento interpessoal.

\subsubsection{Segunda Subdimensão: Práticas Educativas e Instrumentos de Gestão da Ética na Universidade de Brasília}

A segunda parte dos resultados apresenta a subdimensão, Práticas Educativas no sentido de como ocorre os programas educativos na UnB, e instrumentos de Gestão da Ética que poderão ser utilizados junto a Andragogia, para difundir as práticas educativas éticas na Universidade. Esta subdimensão foi caracterizada pela segunda, terceira e quarta pergunta da entrevista estruturada, que buscaram identificar o que os entrevistados percebem em relação ao apoio da UnB quanto a programas educativos para servidores. As perguntas estão associadas ao objetivo deste estudo, qual seja, o de enunciar as possibilidades de implantação de instrumentos de Gestão da Ética, através da teoria elencada nesta pesquisa, à Andragogia, bem como das contribuições dos entrevistados.

A análise da subdimensão 'Práticas Educativas e Instrumentos de educação ética institucional' retratou a resposta à questão 'Você acha que a Universidade apoia programas educativos para os servidores? Em caso positivo, como é dado esse apoio?' Identificaram-se 
cinco categorias: desconheço, apoia, concordo parcialmente, ampliação dos programas, apoio de fachada, as quais foram explicadas, conforme descrições dispostas nos quadros que seguem, em esclarecimento a cada uma dessas categorias.

Foram revelados na primeira triagem dez fragmentos, conforme quadro a seguir, em relação ao vocábulo 'desconheço'. Todos os fragmentos de resposta da primeira triagem foram codificados por letra e número, em que, por exemplo, ' $M$ ' representa o gênero do entrevistado e o número '14' representa a ordem da entrevista. Nesta primeira análise, 'M14' foi escolhido por ser o mais representativo. Essa escolha encontra respaldo na seguinte citação: "infere-se aqui a subjetividade do pesquisador ao conceder a identificação das categorias" (SILVA \& FOSSÁ, 2013:9).

\subsubsection{Categoria 'Desconheço'}

Para a categoria 'desconheço' isolaram-se os padrões repetitivos nos fragmentos codificados por F06, M08, F10, M13, M14, F18, F19, F21, M22, F23, e, em seguida, realizou-se a escolha pelo fragmento mais representativo, M14, em relação à dimensão, conforme demonstra o quadro a seguir. 
Quadro 18. Categoria 'Desconheço'

\begin{tabular}{|c|c|}
\hline Categorial Inicial & Resultado da Categoria Inicial \\
\hline “não sei responder”. (F06) & \multirow{9}{*}{ “Desconheço" (M14) } \\
\hline “não". (M08) & \\
\hline "Não conheço programas educativos sobre esse tema". (F10) & \\
\hline “Não”. (M13) & \\
\hline "Desconheço". (M14) & \\
\hline “[...] desconheço”. (F18) & \\
\hline “desconheço". (F21) & \\
\hline "Acho que sim, mas desconheço". (M22) & \\
\hline $\begin{array}{l}\text { “[...] nunca vi nenhum programa educativo para servidores...”. } \\
\text { (F23) }\end{array}$ & \\
\hline
\end{tabular}

Fonte: elaborado pela autora, a partir dos dados da pesquisa em 2015

Os entrevistados F06, M08, F10, M13, M14, F18, F21, M22, F23 desconhecem o apoio da UnB em relação aos programas educativos para os servidores, ao passo que F10 aponta para o desconhecimento de programas específicos, como em relação à ética. F10 desconhece regras hierárquicas em relações de trabalho e F23 afirma "nunca ter visto programas educativos para servidores."

A esse respeito, desconhecimento por parte dos servidores de programas ofertados pela organização, verifica-se um problema de comunicação organizacional, em que, Cardoso revela:

cada vez mais, torna-se claro como os processos de comunicação contribuem para desenvolver formas de inter-relação mais participativas e, portanto, mais comprometidas, dando maior flexibilidade às organizações como base de sua permanente transformação e facilitando sua interação social de modo responsável para conjugar seus interesses com as condições culturais, econômicas e políticas nas quais se movem (CARDOSO, 2006:1132, 1133). 
A importante contribuição que os processos de comunicação proporcionam à empresa devem ser vistos com maior responsabilidade, posto que, a partir deles, podem ser identificados os problemas e encontrado as soluções de forma mais rápida.

\subsubsection{Categoria 'Apoio'}

Dentro do campo semântico do vocábulo 'apoio', que foi dito por todos os respondentes, foram identificados sete fragmentos de respostas, por F04, F05, M07, F09, F11, F12 e F17, dos quais F11 foi o mais representativo diante da atual conjuntura da universidade. O quadro, a seguir, mostra este resultado.

\section{Quadro 19. Categoria 'Apoio'}

\begin{tabular}{|c|c|}
\hline Categorial Inicial & $\begin{array}{l}\text { Resultado da } \\
\text { Categoria Inicial }\end{array}$ \\
\hline $\begin{array}{l}\text { "[...] a universidade oferece programas educativos aos servidores } \\
{[\ldots] \text { percebe-se resistência das chefias em liberar os servidores para }} \\
\text { participar dos cursos". (F04) }\end{array}$ & \multirow{7}{*}{$\begin{array}{l}\text { “[...] apoia, por meio }[\ldots] \text { de cursos de } \\
\text { capacitação, outros eventos, como } \\
\text { palestras e seminários". (F11) }\end{array}$} \\
\hline $\begin{array}{l}\text { “[...] há vários seminários, oficinas, bem como cursos de } \\
\text { capacitação voltados para atender necessidades específicas da } \\
\text { instituição". (F05) }\end{array}$ & \\
\hline "Sim, apoio é dado". (M07) & \\
\hline $\begin{array}{l}\text { “Sim [...] ações de desenvolvimento e educação e capacitação } \\
\text { desenvolvidos pela Diretoria de Capacitação, Desenvolvimento e } \\
\text { Educação, [...] ações de extensão, canais de comunicação, UnB TV”. } \\
\text { (F09) }\end{array}$ & \\
\hline $\begin{array}{l}\text { "[...] apoia, por meio }[\ldots] \text { de cursos de capacitação, outros eventos, } \\
\text { como palestras e seminários". (F11) }\end{array}$ & \\
\hline “[...] sim, por intermédio do Programa de Capacitação DGP”. (F12) & \\
\hline $\begin{array}{l}\text { "[...] sim, por meio da PROCAP, talvez não tenham a efetividade } \\
\text { garantida, mas é sim forma de incentivo". (F17) }\end{array}$ & \\
\hline
\end{tabular}

Fonte: elaborado pela autora, a partir dos dados da pesquisa em 2015 
Para os entrevistados F04, F05, M07, F09, F11, F12 e F17, a Universidade de Brasília apoia programas educativos que capacitam os servidores. A resposta de F11 foi escolhida como a fala mais representativa, por sintetizar a forma como se dá esse apoio na UnB, quando diz: “[...] apoia, por meio [...] de cursos de capacitação, outros eventos, como palestras e seminários".

Em relação à a esses programas educativos, Sovienski e Stigar (2008:55) afirmam ser de fundamental importância

[...] conhecer o potencial humano como o recurso estratégico mais importante para o desenvolvimento e sucesso institucional; envolver e comprometer todos os servidores no trabalho de melhoria do serviço público, com ênfase na participação dos mesmos no processo de gestão, reconhecer que é necessário capacitar e profissionalizar o servidor para que desenvolva e utilize seu pleno potencial de modo coerente e convergente com os objetivos estratégicos da instituição". [grifo nosso]

A seriedade desse assunto para o futuro institucional é perceptível quando se identifica a necessária conciliação que deve ser feita entre os objetivos da organização com os devidos programas para a capacitação, pois o desejo é de que esses tragam melhorias para a cultura organizacional, bem como para a melhoria do ofício.

\subsubsection{Categoria 'Concordo Parcialmente'}

Dentro do campo semântico da expressão composta 'concordo parcialmente' foram identificados cinco fragmentos de respostas, M01, F02, F03, M15, e M20, dos quais M15 foi o mais representativo, visualizado no quadro a seguir. 


\section{Quadro 20. Categoria 'Concordo Parcialmente'}

\begin{tabular}{|c|c|}
\hline Categorial Inicial & $\begin{array}{c}\text { Resultado da } \\
\text { Categoria Inicial }\end{array}$ \\
\hline $\begin{array}{l}\text { "Muito pouco }[\ldots] \text { o valor anual destinado a } \\
\text { formação do servidor }[\ldots] \text { fachada que tem por } \\
\text { objetivo mascarar a realidade". (M01) }\end{array}$ & \multirow{5}{*}{$\begin{array}{l}\text { "Concordo parcialmente [...] seria importante que a } \\
\text { UnB investisse em programas educativos para a área } \\
\text { ética e disciplinar, tendo em vista que são áreas muito } \\
\text { importante para o desempenho organizacional e que } \\
\text { atualmente não recebem a devida importância da } \\
\text { Administração Superior". (M15) }\end{array}$} \\
\hline $\begin{array}{l}\text { "[...] falta mais divulgação e continuidade desses } \\
\text { programas. Há programas na UnB que envolvem } \\
\text { tratamento psicológico e reciclagem de condutas para } \\
\text { servidores". (F02) }\end{array}$ & \\
\hline “[...] apoio de fachada $[\ldots] ” .($ F03 $)$ & \\
\hline $\begin{array}{l}\text { "Concordo parcialmente [...] seria importante que a } \\
\text { UnB investisse em programas educativos para a área } \\
\text { ética e disciplinar, tendo em vista que são áreas muito } \\
\text { importantes para o desempenho organizacional e que } \\
\text { atualmente não recebem a devida importância da } \\
\text { Administração Superior". (M15) }\end{array}$ & \\
\hline “Considero insipiente esse apoio”. (M20) & \\
\hline
\end{tabular}

Fonte: elaborado pela autora, a partir dos dados da pesquisa em 2015

Os entrevistados, M01, F02, F03, M15, e M20, concordam parcialmente com o apoio dado pela UnB em relação a programas educativos, ao passo que M01 afirma que é “muito pouco [...] o valor anual destinado à formação do servidor [...]", o que justifica não concordar com a verdadeira implementação de programas educativos. Já F02 revela que "falta mais divulgação e continuidade desses programas”. F03 e M20 não reconhecem o apoio, concordando parcialmente. No entanto, M15, além de sintetizar as outras respostas ao dizer "concordo parcialmente", sugere à UnB que invista em programas educativos para a área ética e disciplinar, corroborando dessa forma, com a proposta deste estudo.

Em relação à importância de programas educativos para essas áreas, Matos (2005:4, 5) assim explica:

se as lideranças não confirmarem a lógica da atitude, a lógica formal não garante a necessária credibilidade. Ser ético, como atitude na gestão, significa, em essência: reconhecer o desempenho funcional, propiciar participação nos resultados, estimular o compromisso social e favorecer a educação continuada. 


\subsubsection{Categoria 'Ampliação dos Programas'}

Dentro do campo semântico de 'ampliação dos programas' foram identificados dois fragmentos de respostas na primeira triagem, F02 e M16, sendo que M16, na segunda triagem, apresenta-se como o mais representativo, conforme o quadro a seguir.

Quadro 21. Categoria 'Ampliação dos Programas'

\begin{tabular}{|c|c|}
\hline Categorial Inicial & $\begin{array}{c}\text { Resultado da } \\
\text { Categoria Inicial }\end{array}$ \\
\hline $\begin{array}{l}\text { "[...] falta mais divulgação e continuidade desses programas. } \\
\text { Há programas na UnB que envolvem tratamento psicológico e } \\
\text { reciclagem de condutas para servidores". (F02) }\end{array}$ & \multirow{2}{*}{$\begin{array}{l}\text { “[...] a Universidade deveria ampliar os } \\
\text { programas educativos }[\ldots] \text { o assunto não é } \\
\text { priorizado". (M16) }\end{array}$} \\
\hline $\begin{array}{l}\text { "[...] a Universidade deveria ampliar os programas educativos } \\
{[\ldots] \text { assunto não é priorizado". (M16) }}\end{array}$ & \\
\hline
\end{tabular}

Fonte: elaborado pela autora, a partir dos dados da pesquisa em 2015

Os entrevistados F02 e M16 expõem que, para que haja o apoio de programas educativos por parte da UnB, deverá ocorrer a "ampliação dos programas" já existentes; F02 acrescenta que "falta mais divulgação". No entanto, a mesma entrevistada, (F02), fala de "continuidade desses programas", assim sendo, a palavra "continuidade" é sinônima de “prosseguimento", a qual pertence ao mesmo campo semântico da palavra "ampliar" dita por M16, que é sinônima de "estender", que remete a ideia de "continuidade". Inclusive, M16 acrescenta que o "assunto não é priorizado" na UnB.

Em relação à ‘ampliação de programas', Alledi e Quelhas (2002:01) dizem que “a função de uma universidade é pesquisar, ampliar e disseminar o conhecimento"; assim, verifica-se que o atendimento à essa função corrobora com a necessidade de ampliação apontada pelos entrevistados F02 e M16. 


\subsubsection{Categoria 'Apoio de Fachada'}

'Apoio de fachada' apareceu em dois fragmentos, de M01 e F03, sendo que M01 é o mais representativo, conforme quadro a seguir.

\section{Quadro 22. Categoria 'Apoio de Fachada'}

\begin{tabular}{|l|l|}
\hline \multicolumn{1}{|c|}{ Categorial Inicial } & \multicolumn{1}{|c|}{$\begin{array}{c}\text { Resultado da } \\
\text { Categoria Inicial }\end{array}$} \\
\hline $\begin{array}{l}\text { "Muito pouco }[\ldots] \text { o valor anual destinado à formação } \\
\text { do servidor }[\ldots] \text { fachada que tem por objetivo } \\
\text { mascarar a realidade". (M01) }\end{array}$ & $\begin{array}{l}\text { Muito pouco }[\ldots] \text { o valor anual destinado à formação } \\
\text { do servidor }[\ldots] \text { fachada que tem por objetivo } \\
\text { mascarar a realidade". (M01) }\end{array}$ \\
\hline " $[\ldots]$ apoio de fachada $[\ldots] " .(\mathrm{F} 03)$ & \\
\hline
\end{tabular}

Fonte: elaborado pela autora, a partir dos dados da pesquisa em 2015

M01 e F03 afirmam que o apoio dado é de "fachada", ao passo que M01 acrescenta a informação de que é "muito pouco [...] o valor anual destinado à formação do servidor [...]". Ao pesquisar sobre a informação no Plano Anual de Capacitação (2015), promovido pela Diretoria de Capacitação, Desenvolvimento e Educação do Decanato de Gestão de Pessoas, verificou-se que "no ano de 2015, a projeção para investimento na capacitação e desenvolvimento dos servidores da UnB é de $\mathrm{R} \$ 1.500 .000,00$ (um milhão e quinhentos mil reais), sendo $\mathrm{R} \$ 1.000 .000,00$ (Um milhão de reais) oriundos dos recursos do Tesouro Nacional, gerenciados pela FUB e R\$ 500.000,00 (quinhentos mil reais), relativos aos recursos próprios da FUB” (UNB, 2015(a):5).

Desse contexto, extrai-se a seguinte informação: o número de docentes do quadro e o número de técnico-administrativos, segundo a página eletrônica do Decanato de Planejamento e Orçamento/UnB (UNB, 2014) era de 2.695 docentes em seu quadro 
(incluindo substitutos e visitantes), e 2.623 técnico-administrativos. O documento 'Plano Anual de Capacitação 2015' da Universidade de Brasília indica que há previsão do processo de capacitação para os "servidores públicos federais, docentes e técnico-administrativos, pertencentes ao quadro da FUB e em exercício na Instituição; Servidores Públicos Federais em exercício na FUB; Profissionais que estão em regime de contratação temporária regidos pela lei 8.745/93".

Diante dos dados disponíveis em tais documentos, realizou-se o seguinte cálculo: o valor de projeção para o ano de 2015 para capacitação e desenvolvimento dos servidores da UnB, dividido pelo número informado, 2.695 docentes, mais 2.623 técnico-administrativos. Verifica-se, com isso, a quantidade total de servidores, que é de 5.318. Assim, ao dividir $\mathrm{R} \$ 1.500 .000,00$ (um milhão e quinhentos mil reais) pelo número total de servidores, o valor encontrado é de $\mathrm{R} \$ 282,06$ (duzentos e oitenta e dois reais e seis centavos) por ano, para cada servidor, sem considerar os profissionais que estão em regime de contratação temporária regidos pela Lei 8.745/93. Registra-se que esse valor não é exato, haja vista a UnB também realizar treinamentos informais, como por exemplo, nos próprios setores de trabalho, de modo a capacitar os novos servidores para a realização do ofício, além de outros treinamentos pagos pela UnB, como os programas de pós-graduação para os servidores da FUB e treinamentos não ofertados pela PROCAP/DGP.

Assim, verifica-se que “o maior desafio da administração universitária é garantir os meios e os recursos necessários para investir no seu quadro de pessoal de forma contínua, quer na capacitação, quer nas condições de trabalho e na avaliação" (BERNARDES, 2003:3).

Foram excluídas as palavras-chave e expressões compostas 'pouco dinheiro para a educação do servidor', 'mais divulgação de programas educativos' e 'resistência das chefias', haja vista não ter tido repetição ou por terem apresentado apenas uma ocorrência, no 
sentido estrito dessas palavras nas respostas dos entrevistados. Por esse motivo, foram eliminados do quadro da segunda triagem resultado das categorias iniciais.

Quadro 23. Quadro Geral da Segunda Subdimensão - Questão 2

\begin{tabular}{|c|c|c|c|}
\hline Subdimensão de Estudo & $\begin{array}{c}\text { Categorias Iniciais } \\
\text { Trechos E Expressões } \\
\text { Compostas Em Negrito }\end{array}$ & $\begin{array}{c}\text { Categorias } \\
\text { Intermediárias }\end{array}$ & Categorias Finais \\
\hline \multirow{5}{*}{$\begin{array}{c}\text { Práticas educativas e } \\
\text { instrumentos de educação } \\
\text { ética institucional } \\
\text { (ANÍSIO TEIXEIRA } \\
\text { (1936); PASSOS (2010); } \\
\text { PAULO FREIRE (2007); } \\
\text { ZYLBERSTZTAJN (2002); } \\
\text { KNOWLES (1980); VOGT } \\
\text { (2007) }\end{array}$} & $\begin{array}{l}\text { "Muito pouco [...] o valor } \\
\text { anual destinado à formação } \\
\text { do servidor [...] fachada que } \\
\text { tem por objetivo mascarar a } \\
\text { realidade". (M01) }\end{array}$ & Fachada & \multirow{5}{*}{$\begin{array}{l}\text { O entendimento em } \\
\text { relação ao apoio da } \\
\text { UnB aos programas } \\
\text { educativos é } \\
\text { desconhecido. No } \\
\text { entanto, observa-se } \\
\text { que não há consenso } \\
\text { acerca da oferta, haja } \\
\text { vista que o apoio seja } \\
\text { de fachada. }\end{array}$} \\
\hline & $\begin{array}{l}\text { "[...] apoia, por meio [...] de } \\
\text { cursos de capacitação, outros } \\
\text { eventos, como palestras e } \\
\text { seminários". (F11) }\end{array}$ & Apoia & \\
\hline & "Desconheço". (M14) & Desconheço & \\
\hline & $\begin{array}{l}\text { "Concordo parcialmente } \\
\text { [...] seria importante que a } \\
\text { UnB investisse em } \\
\text { programas educativos para a } \\
\text { área ética e disciplinar, tendo } \\
\text { em vista que são áreas muito } \\
\text { importante } \\
\text { desempenho para } \\
\text { e que atualmente não } \\
\text { recebem a } \\
\text { importância } \\
\text { Administração }\end{array}$ & $\begin{array}{c}\text { Concordo } \\
\text { parcialmente }\end{array}$ & \\
\hline & $\begin{array}{l}\text { "[...] a universidade deveria } \\
\text { ampliar os programas } \\
\text { educativos [...] assunto não } \\
\text { é priorizado". (M16) }\end{array}$ & $\begin{array}{l}\text { Ampliar os } \\
\text { programas } \\
\text { educativos }\end{array}$ & \\
\hline
\end{tabular}

Fonte: elaborado pela autora, a partir dos dados da pesquisa em 2015

Após analisar e interpretar os fragmentos de fala de todos os entrevistados, por meio da interpretação por palavras-chaves ou expressões compostas que comportam as categorias iniciais, foram criadas as categorias intermediárias. A interpretação realizou-se 
com base no referencial teórico exposto na pesquisa. A categoria final foi resultado das categorias anteriores, constituindo uma síntese das ideias apresentadas pelos entrevistados, e assim escrita de forma coerente e coesa para o entendimento geral. É importante salientar que a análise destas categorias permite compreender a subdimensão aqui tratada.

Abaixo, seguem as considerações dos teóricos sobre esta subdimensão de estudo, os quais estiveram também presentes na fundamentação teórica deste trabalho.

De acordo com Passos (2010), esta subdimensão de 'Práticas Educativas e Instrumentos de educação ética institucional' revela que programas educativos devem ser priorizados nas organizações, principalmente em se tratando de um tema que envolve relacionamentos. Teixeira (1936), (Freire apud CAMPOS, 2007), (Zilberstztajn, 2002, apud GOMES 1999); (Knowles 1978 e 1980, apud VOGT 2007) ratificam tal entendimento.

O ambiente laboral deve estar composto por membros educados e que possuam iniciativa individual e de adaptabilidade (TEIXEIRA, 1936) para o bom andamento das organizações. TEIXEIRA apud CAMPOS (2007:39) acrescenta que, caso os integrantes não possuam as habilidades anteriormente citadas, "serão esmagados pelas mudanças em que se virem envolvidos e cujas as associações ou significados eles não percebem". A importância da educação para que os princípios éticos institucionais sejam difundidos perpassa também pela noção de que

\footnotetext{
faz-se necessário investir em atividades pedagógicas capazes de promover o esclarecimento e imprimir uma nova mentalidade, novos valores e, consequentemente nova relação da população com o serviço público. As normas codificadas e as punições podem ajudar, porem são incapazes de fazer a passagem necessária (PASSOS, 2010:163).
}

Esta citação sintetiza a importância da promoção da educação ética em uma organização, haja vista o marco regulatório ser insuficiente para a manutenção de comportamentos desejáveis à vida em sociedade. 
Outro aspecto, sobre este mesmo assunto, é o que revela Zylberstztajn (2002), quando diz que o comportamento ético representa um valor da sociedade atual e que existem falhas no comportamento ético dos indivíduos e como estas pessoas constituem as organizações. As organizações estão cheias de todos os desvios possíveis e conhecidos do comportamento humano. Por isto, a necessidade em lutar contra o individualismo e o egoísmo em deixar de reconhecer a existência do outro e passar por cima de qualidades como tolerância, cooperação social e equidade (PASSOS, 2010).

A introdução da ética nas organizações, por meio da educação que é necessária, possibilita aos indivíduos, como revela Passos (2010:166),

\footnotetext{
"que tenham alegria com o que fazem, além de fortalecer o compromisso com a organização, renovando e colocando em prática o poder criativo e produtivo que possuam, além de solidariedade, estimulando enfim, as condições necessárias à manutenção da organização".
}

Esta educação pode abrolhar por meio da Andragogia, haja vista ser a arte e a ciência de ajudar os adultos a aprenderem, conforme explica Knowles (1980), que a Andragogia é outro modelo de princípios, os quais foram abordados na fundamentação teórica desse estudo sobre a aprendizagem, e que pode ser usado como um paralelo aos princípios utilizados pela pedagogia para ensinar as crianças. Para Knowles (1978 apud VOGT, 2007:43) a dinâmica metodológica, no ensino de adultos, tende a se mover nos métodos tradicionais a favor dos métodos que exploram, principalmente a experiência do aprendiz, em cenários educativos como grupo de discussão, jogo de papéis, workshops e várias combinações de métodos interativos.

Paulo Freire (apud CAMPOS, 2007:39) também afirma que "precisamos hoje, no Brasil, talvez mais do que ontem, de uma prática educativa exemplarmente democrática [...]. 
Semanas em que se apresentasse a história da democracia, em que se debatessem a relação entre democracia e ética". Portanto, as citações dos teóricos aqui apresentadas, bem como todo o contexto da fundamentação teórica do presente estudo, desvelam a importância da educação ética de modo a coibir os desvios éticos que aniquilam os relacionamentos.

- Terceira parte dos resultados

A terceira parte dos resultados apresenta a mesma subdimensão descrita anteriormente, 'Práticas Educativas e Instrumentos de Educação Ética Institucional'. Esta subdimensão foi também caracterizada pela terceira e quarta perguntas da entrevista estruturada, que buscou obter dos entrevistados sugestões para a difusão da educação ética na UnB. Essas perguntas estão associadas ao objetivo específico de 'enunciar as possibilidades de implantação de instrumentos de Gestão da Ética', e, dessa forma, contribuir para a educação ética na instituição, uma vez que, a partir das sugestões dos respondentes sobre os instrumentos que poderão ser utilizados, podem-se verificar quais são os mais citados e quais funcionam, na visão da maioria, como uma melhor prática a ser adotada.

A análise da subdimensão 'Práticas Educativas e Instrumentos de Educação Ética Institucional' retratou a resposta à questão 'Partindo-se da premissa de que a educação ética, de uma forma geral, propicia uma vida melhor para as pessoas, o que você acha que a Comissão de Ética pode fazer para transformar essa expectativa em realidade?'. Foram identificadas quatro categorias: divulgar o trabalho da Comissão de Ética; investimentos da Administração Superior; palestras; e seminários; as quais são explicadas conforme descrições dispostas nos quatro quadros que se seguem. 


\subsubsection{Categoria 'Divulgar o Trabalho da Comissão de Ética - Questão 3'}

Foram revelados, na primeira triagem, sete fragmentos em relação à categoria 'Divulgar o trabalho da Comissão de Ética', em que buscaram-se isolar padrões repetitivos nos fragmentos codificados por F02, F03, F09, F11, M13 e F23, especificamente, em relação

a frase 'Divulgar o trabalho da Comissão de Ética', assim como outras dentro do mesmo campo semântico. Conforme já dito, mas por uma questão de Andragogia, todos os fragmentos de resposta da primeira triagem foram codificados por letra e número, em que, por exemplo, 'M' representa o gênero do entrevistado e o número '13' representa a ordem da entrevista, nesta primeira análise. Registra-se, para análise do quadro a seguir, que o 'M13' foi definido como o mais representativo.

Quadro 24. Categoria 'Divulgar o Trabalho da Comissão de Ética'

\begin{tabular}{|c|c|}
\hline Categorial Inicial & Resultado da Categoria Inicial \\
\hline Questão 03 & Questão 03 \\
\hline $\begin{array}{l}\text { "[...] divulgar a Comissão [...] eventos, e-mails no informe rede, } \\
\text { panfletos...". (F02) }\end{array}$ & \multirow{6}{*}{$\begin{array}{l}\text { 3- "Realizar atividades educativas } \\
{[\ldots] \text { divulgar o código de ética e a }} \\
\text { existência e papel da } \\
\text { Comissão }[\ldots] " \text { ". (M13) }\end{array}$} \\
\hline “[...] divulgação da Comissão e seu papel...”. (F03) & \\
\hline "Divulgar o trabalho e fazer seminários sobre o tema". (F05) & \\
\hline $\begin{array}{l}\text { "Divulgar ações da Comissão [...] para possibilitar a constante reflexão } \\
\text { de debates, filmes, palestras, elaborar manuais, cartazes...". (F09) }\end{array}$ & \\
\hline "Divulgar seu trabalho $[\ldots] " .(F 11)$ & \\
\hline $\begin{array}{l}\text { "Realizar atividades educativas }[\ldots] \text { divulgar o código de ética e a } \\
\text { existência e papel da Comissão }[\ldots] " \text {. (M13) }\end{array}$ & \\
\hline
\end{tabular}


"[...] divulgar seu trabalho $[\ldots] "$. (F23)

Fonte: elaborado pela autora, a partir dos dados da pesquisa em 2015

Os entrevistados F02, F03, F09, F11, M13 e F23 expõem que, ao “divulgar a Comissão de Ética na UnB”, a comissão estará desenvolvendo a educação ética, e assim transformando a expectativa de uma vida melhor para os servidores da UnB, haja vista que a pergunta quer justamente identificar, sob o olhar do entrevistado servidor da UnB, se é aplicada uma educação ética, e se ela propiciaria uma vida melhor para as pessoas, além de verificar o que este servidor acha que a Comissão de Ética pode fazer para transformar esta expectativa em realidade.

Em relação à importância da divulgação de serviços, realizou-se uma pesquisa na área de Marketing, em que o teórico Las Casas (2006:377) revela que "ao divulgar um produto ou serviço, os consumidores poderão se sentir estimulados a comprá-lo, tanto pelo efeito da persuasão da comunicação, como pela informação que adquirem”.

Ao trazer esta citação para realidade de um órgão público, os efeitos são os mesmos, haja vista a importância da divulgação de trabalhos, com vistas à efetividade de ações. Quanto à questão do 'comprar', informada por Las Casas (op.cit.), esta pode ser usada em analogia ao acesso da comunidade universitária aos serviços dessa comissão, por meio de consultas, demandas ou de busca por capacitação na área ética. 


\subsubsection{Categoria 'Investimento da Administração Superior' - Questão 3}

'Investimento da Administração Superior' aparece em dois fragmentos de respostas, M15 e M20, dos quais M20 se mostrou mais representativo.

\section{Quadro 255. Categoria 'Investimento da Administração Superior' - Questão 3}

\begin{tabular}{|c|c|}
\hline Categorial Inicial & Resultado da Categoria Inicial \\
\hline Questão 03 & Questão 03 \\
\hline $\begin{array}{l}\text { "[...] caso a administração superior queira }[\ldots] \\
\text { investimento para o alcance do objetivo". (M15) }\end{array}$ & $\begin{array}{l}\text { "A UnB poderia tratar e implementar os seguintes } \\
\text { aspectos: criar comitês locais de ética com atividades }\end{array}$ \\
\hline $\begin{array}{l}\text { "A UnB poderia tratar e implementar os seguintes } \\
\text { aspectos: criar comitês locais de ética com atividades } \\
\text { coordenadas pela CE-UnB [...] palestras e seminários de } \\
\text { grande expressão e legitimidade[...] formação de } \\
\text { gestores em ética (tanto de ética em pesquisa, como } \\
\text { ética nas relações laborais) }[\ldots] \text { fórum de discussão } \\
\text { online, fornecer estrutura, recursos financeiros e } \\
\text { recursos humanos ao CE/UnB para que este } \\
\text { implemente estas propostas". (M20) }\end{array}$ & $\begin{array}{l}\text { coordenadas pela CE-UnB [...] palestras e seminários } \\
\text { de grande expressão e legitimidade [...] formação de } \\
\text { gestores em ética(tanto de ética em pesquisa, como } \\
\text { ética nas relações laborais) [...] fórum de discussão } \\
\text { online, fornecer estrutura, recursos financeiros e } \\
\text { recursos humanos ao CE/UnB para que este } \\
\text { implemente estas propostas". (M20) }\end{array}$ \\
\hline
\end{tabular}

Fonte: elaborado pela autora, a partir dos dados da pesquisa em 2015.

Tanto o entrevistado M15 quanto o M20 afirmam a necessidade de investimento da Administração Superior para a efetivação dos trabalhos da comissão. Esse investimento é citado por M20, não só no aspecto financeiro, mas também em relação à 'criação de comitês locais de ética, com atividades coordenadas pela CE-UnB'. O entrevistado cita também ações educativas, inclusive com os gestores, "criação de um fórum de discussão online", e que o investimento da Administração Superior se dará também ao “fornecer estrutura”, uma vez que a comissão não dispõe de uma sala própria. Por fim, o entrevistado cita a necessidade de investimento ao obter "recursos humanos". 
Em relação aos investimentos da administração na capacitação dos servidores, posto que por meio de ações educativas da Comissão de Ética, esses servidores serão capacitados. Para compreensão da mensagem que se deseja transmitir, Amaral (2014:551) afirma que "[...] para que a administração pública brasileira seja, de fato, um dos fatores de riqueza e de vantagem competitiva no país, será imprescindível investir nos servidores”. Eis aí a necessária atenção a departamentos que trabalhem com a questão preventiva e disciplinar, posto que inúmeros processos administrativos poderão ser evitados, proporcionando-se, assim, economia, e celeridade aos processos tramitados em órgãos públicos.

\subsubsection{Categoria 'Palestras' - Questão 3}

O termo 'Palestras' aparece em cinco fragmentos de respostas: M01, F09, F10, F18, e M20, dos quais F18 é o mais representativo.

Quadro 26. Categoria 'Palestras' - Questão 3

\begin{tabular}{|c|c|}
\hline Categorial Inicial & Resultado da Categoria Inicial \\
\hline Questão 03 & Questão 03 \\
\hline
\end{tabular}




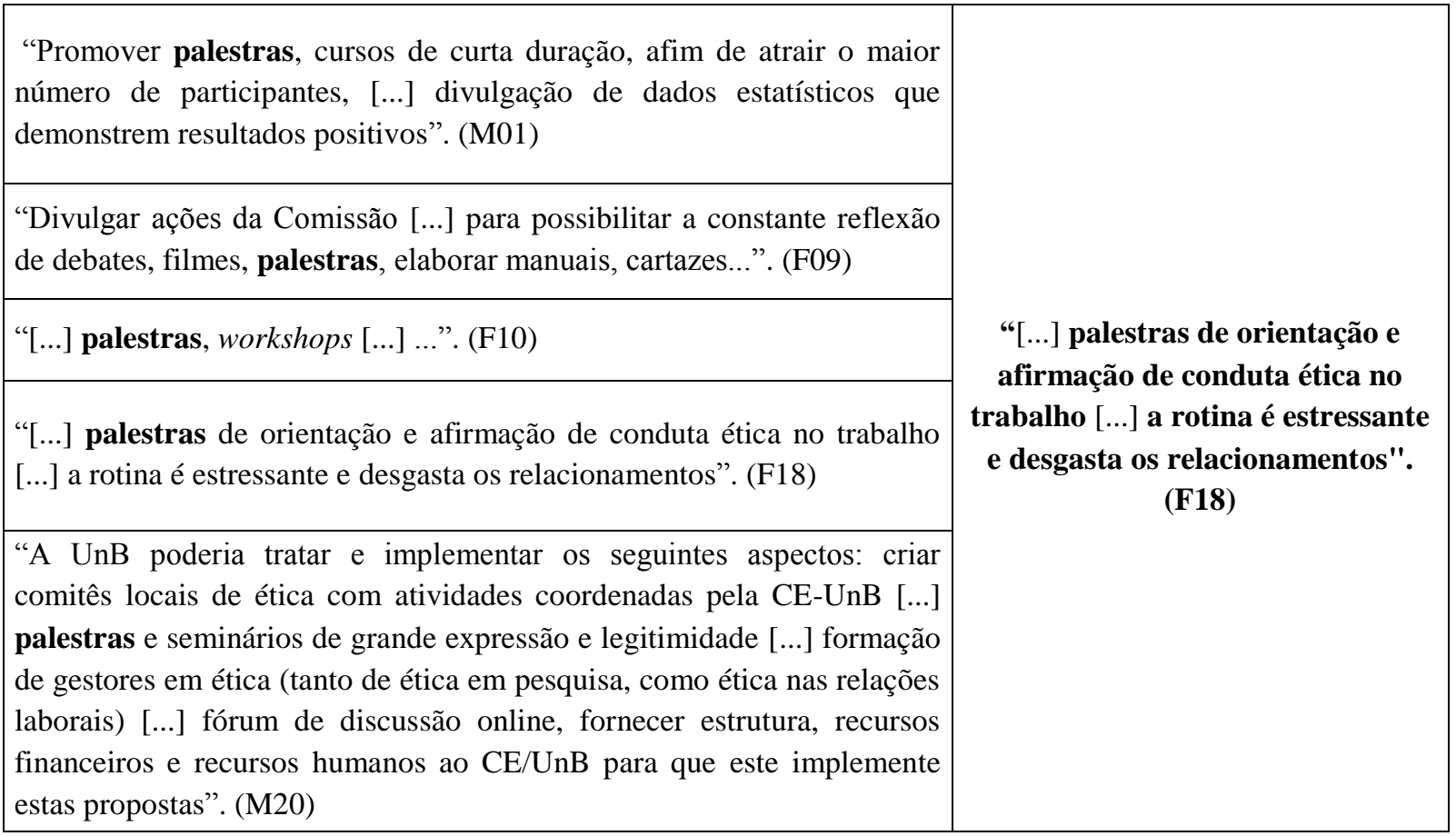

Fonte: elaborado pela autora, a partir dos dados da pesquisa em 2015

Os entrevistados M01, F09, F10, F18, e M20 citam 'palestras' como uma ação para a educação ética, ao passo que M01, acrescenta a "divulgação de dados estatísticos que demonstrem resultados positivos". Já F09 acrescenta a "elaboração de manuais e cartazes". Essas sugestões poderão ser somadas às palestras, haja vista seu caráter de reforço. F18, por sua vez, diz que "a rotina é estressante e desgasta os relacionamentos".

Diante do exposto, verifica-se a necessidade de palestras dirigidas aos servidores, em que o enfoque deveria ser a divulgação e a busca pela disseminação da informação para "o maior número de participantes", conforme a fala de M01. Palestras, na maioria das vezes, são mais simples de preparar, pelo baixo investimento em relação a outras formações (GALINDO e INFORSATO, 2008), o que demonstra mais uma vantagem, do ponto de vista educacional e econômico.

\subsubsection{Categoria 'Seminários' - Questão 3}


'Workshops' ou 'cursos de curta duração' e 'seminários' aparecem em seis fragmentos - M01, F04, F05, M08, F10 e M20 - dos quais o mais representativo foi M20, haja vista a ênfase dada pelo entrevistado de que os seminários sejam de grande expressão e legitimidade para uma real promoção da educação ética.

Quadro 27. Categoria 'Seminários'

\begin{tabular}{|c|c|}
\hline Categorial Inicial & Resultado da Categoria Inicial \\
\hline Questão 03 & Questão 03 \\
\hline $\begin{array}{l}\text { "Promover palestras, cursos de curta duração, afim } \\
\text { de atrair o maior número de participantes, [...] } \\
\text { divulgação de dados estatísticos que demonstrem } \\
\text { resultados positivos". (M01) }\end{array}$ & \multirow{6}{*}{$\begin{array}{l}\text { "A UnB poderia tratar e implementar os seguintes } \\
\text { aspectos: criar comitês locais de ética com atividades } \\
\text { coordenadas pela CE-UnB [...] palestras e seminários } \\
\text { de grande expressão e legitimidade [...] formação de } \\
\text { gestores em ética (tanto de ética em pesquisa, como } \\
\text { ética nas relações laborais) [...] fórum de discussão } \\
\text { online, fornecer estrutura, recursos financeiros } \\
\text { recursos humanos ao CE/UnB para que este } \\
\text { implemente estas propostas". (M20) }\end{array}$} \\
\hline “[...] workshop e oficinas $[\ldots] "$... (F04) & \\
\hline $\begin{array}{l}\text { "Divulgar o trabalho e fazer seminários sobre o } \\
\text { tema". (F05) }\end{array}$ & \\
\hline $\begin{array}{l}\text { "Promover e elaborar cursos e Workshops [...]". } \\
\text { (M08) }\end{array}$ & \\
\hline “[...] palestras, workshops $[\ldots] "$. (F10) & \\
\hline $\begin{array}{l}\text { "A UnB poderia tratar e implementar os seguintes } \\
\text { aspectos: criar comitês locais de ética com atividades } \\
\text { coordenadas pela CE-UnB [...] palestras e seminários } \\
\text { de grande expressão e legitimidade [...] formação de } \\
\text { gestores em ética (tanto de ética em pesquisa, como } \\
\text { ética nas relações laborais) [...] fórum de discussão } \\
\text { online, fornecer estrutura, recursos financeiros e } \\
\text { recursos humanos ao CE/UnB para que este } \\
\text { implemente estas propostas". (M20) }\end{array}$ & \\
\hline
\end{tabular}

Fonte: elaborado pela autora, a partir dos dados da pesquisa em 2015

Dentro do campo semântico de workshops e seminários, e eventos similares de curta duração, os quais foram citados por M01, F04, F05, M08, F10 e M20 como ações de 
treinamentos que promovem a educação ética, M20, por sua vez, acrescenta-se que para atingir o objetivo proposto pela pergunta de 'transformar esta expectativa em realidade' em relação a educação ética dos servidores, estes seminários devem ser de 'grande expressão e legitimidade'. Inclusive, M20 foi escolhido como o fragmento de fala mais representativa.

Acerca dessas ações de treinamento, Borges-Andrade et al., dizem que

as ações de treinamento, desenvolvimento e qualificação do trabalhador ocupam um dos papéis centrais no conjunto de práticas, que denominamos gestão de pessoas, em contexto organizacional. Seus impactos, por sua vez, são fundamentais [...] para o ajuste indivíduo - trabalho que se traduzem em diferenças de desempenho individuais e coletivos (BORGES-ANDRADE et al., 2006:23) [grifo nosso]

Verifica-se que, ao participar de ações de treinamento, a resultante dessa participação é a capacitação variável basilar para o ajuste dos servidores aos objetivos da organização. 'Serviço de orientação, criação de comitês locais, formação de gestores em ética, panfletos, cartazes e criação de manuais' tiveram apenas uma ocorrência em todas as respostas dos entrevistados, portanto, foram excluídas do quadro da segunda triagem de categorias iniciais, por não apresentarem repetição nas respostas dos entrevistados. Logo, não compõem o quadro resumido, a seguir.

Quadro 28. Quadro Geral da Segunda Subdimensão - Questão 3 


\begin{tabular}{|c|c|c|c|}
\hline $\begin{array}{l}\text { Subdimensão } \\
\text { do Estudo }\end{array}$ & $\begin{array}{c}\text { Categorias Iniciais } \\
\text { Trechos e Expressões Compostas em } \\
\text { Negrito }\end{array}$ & $\begin{array}{c}\text { Categorias } \\
\text { Intermediárias }\end{array}$ & Categorias Finais \\
\hline & & Questão 3 & \\
\hline & $\begin{array}{l}\text { "Realizar atividades educativas [...] divulgar } \\
\text { o código de ética e a existência e papel da } \\
\text { Comissão...". (M13) }\end{array}$ & $\begin{array}{c}\text { Divulgar a } \\
\text { Comissão de Ética }\end{array}$ & \multirow{3}{*}{$\begin{array}{l}\text { As sugestões de } \\
\text { instrumentos de } \\
\text { educação ética } \\
\text { institucional são: } \\
\text { divulgar o papel da } \\
\text { Comissão de Ética, } \\
\text { realizar palestras e } \\
\text { seminários de grande } \\
\text { expressão e } \\
\text { legitimidade e pelo } \\
\text { investimento da } \\
\text { administração } \\
\text { superior. }\end{array}$} \\
\hline $\begin{array}{l}\text { Educativas e } \\
\text { Instrumentos de } \\
\text { educação ética } \\
\text { institucional }\end{array}$ & $\begin{array}{l}\text { "[...] palestras de orientação e afirmação de } \\
\text { conduta ética no trabalho [...] a rotina é } \\
\text { estressante e desgasta os relacionamentos". } \\
\text { (F18) }\end{array}$ & Palestras & \\
\hline 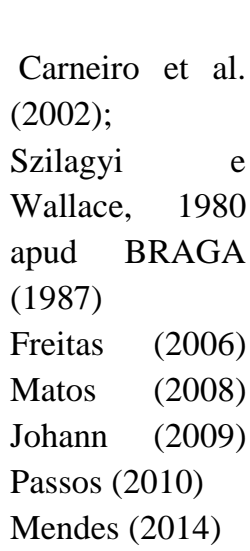 & $\begin{array}{l}\text { "A UnB poderia tratar e implementar os } \\
\text { seguintes aspectos: criar comitês locais de } \\
\text { ética com atividades coordenadas pela CE- } \\
\text { UnB }[\ldots] \text { palestras e seminários de grande } \\
\text { expressão e legitimidade }[\ldots . .] \text { formação de } \\
\text { gestores em ética (tanto de ética em pesquisa, } \\
\text { como ética nas relações laborais) [...] fórum de } \\
\text { discussão online, fornecer estrutura, recursos } \\
\text { financeiros e recursos humanos ao CE/UnB } \\
\text { para que este implemente estas propostas." } \\
\text { (M20) }\end{array}$ & $\begin{array}{l}\text { Investimento da } \\
\text { Administração } \\
\text { superior; } \\
\text { Seminários }\end{array}$ & \\
\hline
\end{tabular}

Fonte: elaborado pela autora, a partir dos dados da pesquisa em 2015

Após analisar e interpretar os fragmentos de fala de todos os entrevistados, por meio da interpretação por palavras-chaves ou expressões compostas - as categorias iniciais foram compostas as categorias intermediárias. A interpretação foi feita com base no que os autores afirmam a respeito, o que dá respaldo teórico à pesquisa. A categoria final foi o resultado das categorias anteriores, constituindo uma síntese das ideias apresentadas pelos entrevistados, e assim escrita de forma coerente e coesa para o entendimento geral. Importa salientar que a análise dessas categorias auxilia no exame da subdimensão aqui tratada.

Sobre esta subdimensão 'Práticas Educativas e Instrumentos de Educação Ética Institucional', Mendes diz que

a perspectiva sistêmica adotada assume que a efetividade da gestão da ética depende mais da sinergia entre os instrumentos que dos efeitos produzidos por cada um. 
Assim, a combinação entre as diferentes medidas produzem efeito significativo, em que o conjunto dos efeitos é muito maior que a soma dos efeitos de cada instrumento (MENDES, 2014:101).

Por isso, realizou-se este levantamento, por intermédio da entrevista estruturada, de sugestões dadas pelos entrevistados em relação aos instrumentos de educação ética, aqui tratado no campo de atividades de cunho educativo. Esse levantamento, como abordado anteriormente na análise das categorias iniciais, revelou ferramentas que poderão ser utilizadas e que provocarão um impacto maior juntas do que se forem aplicadas isoladamente, o que corrobora com a fala de Mendes (op.cit.:101), ao defender que "a combinação entre as diferentes medidas produzem efeito significativo, em que o conjunto dos efeitos é muito maior que a soma dos efeitos de cada instrumento". A autora assim explana que

[...] os resultados desta pesquisa demonstram que a função educacional estabelecida como prioritária não atingiu o desenvolvimento necessário para promover a formação para a ética em todos os níveis hierárquicos da administração pública. Apenas o grupo de servidores que trabalha nas Comissões está sendo capacitado de forma sistemática (MENDES, op.cit.: 232).

Diante do exposto, o interesse em trabalhar os instrumentos de gestão ética, em uma perspectiva andragógica, busca suprir essa lacuna, capacitando o maior número possível de servidores, sistematicamente.

A análise da subdimensão 'Práticas Educativas e Instrumentos de Educação Ética Institucional' retratou a resposta à questão 'Em caso negativo, em que, na sua opinião, seria impossível o desenvolvimento de um trabalho de conscientização da ética na UnB, e quais os motivos que impediriam essa implementação?”. Foram identificadas três categorias: resistência das pessoas, falta de apoio da administração superior, obstáculos a serem vencidos. Essas são explicitadas conforme descrições dispostas nos quadros que se seguem, em explicação a cada uma dessas categorias. 
Nesse momento, são feitas as triagens da questão número 4, em relação a mesma subdimensão das questões número 2 e 3, citadas anteriormente. A quarta pergunta apresentou 14 ocorrências 'sem resposta', as quais não serão consideradas na categoria intermediária, por não terem sugestões a acrescentar.

\subsubsection{Categoria 'Resistência das Pessoas' - Questão 4}

Dentro do campo semântico de 'resistência das pessoas' foram identificados dois fragmentos de respostas, M13 e F19, dos quais a de F19 é mais representativa, conforme quadro a seguir.

Quadro 29. Categoria 'Resistência das Pessoas' - Questão 4

\begin{tabular}{|c|c|}
\hline \multicolumn{1}{|c|}{ Categorial Inicial } & \multicolumn{1}{|c|}{ Resultado da Categoria Inicial } \\
\hline \multicolumn{1}{|c|}{ Questão 04 } & \multicolumn{1}{|c|}{ Questão 04 } \\
\hline $\begin{array}{l}\text { "Falta de interesse da comunidade universitária em } \\
\text { atuar nesse tipo de comissão". (M13) }\end{array}$ & $\begin{array}{l}\text { "Resistência das pessoas em participar de } \\
\text { qualquer tipo de ação educativa". (F19) }\end{array}$ \\
\hline $\begin{array}{l}\text { "Resistência das pessoas em participar de qualquer } \\
\text { tipo de ação educativa". (F19) }\end{array}$ & \\
\hline
\end{tabular}

Fonte: elaborado pela autora, a partir dos dados da pesquisa em 2015.

Os entrevistados M13 e F19 relatam que um dos motivos que impediria a implementação de uma conscientização ética na UnB seria a "falta de interesse da comunidade universitária" (M13), assim como a "resistência das pessoas em participar de qualquer tipo de ação educativa" (F19). 
A esse respeito, Sales e Silva manifestam a seguinte solução, revelada a partir de um estudo de caso, conforme o que segue:

o mau planejamento, as falhas de comunicação, a ausência de um líder participativo e atuante são fatores geradores de resistência, portanto esta não é necessariamente um obstáculo a ser enfrentado, ela pode ser encarada como uma forma de evitar um mal resultado ao final da implantação de mudanças (p.15) (...) é preciso quebrar o paradigma da resistência, deixar de vê-la como a grande vilã ou algo que deva ser ultrapassado, eliminado. Já está chegada a hora de mudar a visão e encarar a resistência como algo que vá auxiliar o processo de mudanças, já que esta pode servir como ferramenta para identificar problemas, falhas e mau planejamento. Além disso, a resistência pode contribuir para proporcionar um clima altamente dinâmico, flexível e mutável dentro das organizações, observando-se novos modelos de gestão (SALES \& SILVA, 2007:15).

Para identificar a resistência das pessoas em participar de atividades, deve-se verificar os motivos, para atuar diretamente nos fatores causadores da resistência, e assim fazer um planejamento inclusivo, pautado em novos modelos de gestão.

\subsubsection{Categoria 'Falta de Apoio da Administração Superior' - Questão 4}

'Falta de apoio da Administração Superior' e expressões compostas de mesmo campo semântico, aparecem em dois fragmentos - M14 e F23 - sendo que F23 é o mais representativo, haja a vista a necessidade que a comissão tem de ter uma provisão financeira proveniente da Administração Superior. 
Quadro 30. Categoria 'Falta de Apoio da Administração Superior' - Questão 4

\begin{tabular}{|c|c|}
\hline Categorial Inicial & Resultado da Categoria Inicial \\
\hline Questão 04 & Questão 04 \\
\hline $\begin{array}{l}\text { "[...] se não houver um diferencial de qualidade e conceito público para } \\
\text { consciência ética no comando, uma vez que, estamos vivendo um } \\
\text { momento moral ao esboçar uma nova conscientização de processo ético } \\
\text { para avaliar e julgar". (M14) }\end{array}$ & \multirow{2}{*}{$\begin{array}{l}\text { "Acredito que o principal } \\
\text { empecilho seria a falta de apoio da } \\
\text { Administração superior" (F23) }\end{array}$} \\
\hline $\begin{array}{l}\text { "Acredito que o principal empecilho seria a falta de apoio da } \\
\text { Administracão superior". (F23) }\end{array}$ & \\
\hline
\end{tabular}

Fonte: elaborado pela autora, a partir dos dados da pesquisa em 2015

Os entrevistados M14 e F23 afirmam que a falta de apoio da Administração Superior, bem como uma consciência ética no comando são fatores essenciais para o desenvolvimento de um trabalho de conscientização da ética na UnB.

O Estatuto e Regimento Geral da UnB, em seu Capítulo III, Art. 11, diz que "a Administração Superior da Universidade de Brasília tem como órgãos deliberativos, normativos e consultivos o Conselho Universitário, o Conselho de Ensino, Pesquisa e Extensão e o Conselho de Administração; como órgão consultivo, o Conselho Comunitário, e, como órgão executivo, a Reitoria”. Assim, a partir do entendimento de quem é a Administração Superior podem ser trabalhadas as medidas necessárias para a obtenção do referido apoio.

É necessário o envolvimento da Administração Superior com os trabalhos educativos a serem realizados pela Comissão de Ética, haja vista serem programas de qualidade para a organização, por provocarem mudanças comportamentais. A esse respeito, Tolov Júnior (1994:07) diz que

não devemos ter assunto tão falado quanto o fracasso de programas de mudança pelo não envolvimento da alta administração. Qualidade é um programa de mudanças comportamentais, portanto, estamos e estaremos sempre falando de pessoas. Mudanças comportamentais exigem alto esforço, dedicação e perseverança e isto tem que vir do topo da organização. 


\subsubsection{Categoria 'Obstáculos a Serem Vencidos' - Questão 4}

Dentro do campo semântico da frase 'obstáculos a serem vencidos' aparecem três ocorrências, M07, F12 e M15, dos quais, o mais representativo foi M15, haja a vista a totalidade das respostas, conforme o quadro a seguir.

Quadro 31. Categoria 'Obstáculos a Serem Vencidos' - Questão 4

\begin{tabular}{|c|c|}
\hline Categorial Inicial & Resultado da Categoria Inicial \\
\hline Questão 04 & Questão 04 \\
\hline $\begin{array}{l}\text { "É possível desde que seja implementado ações e } \\
\text { aconselhando os servidores". (M07) }\end{array}$ & \multirow{3}{*}{$\begin{array}{l}\text { "Não vejo impedimentos, mas sim obstáculos a } \\
\text { serem vencidos". (M15) }\end{array}$} \\
\hline $\begin{array}{l}\text { “[...] não existe impossível, existe falta de vontade } \\
{[\ldots] " .(F 12)}\end{array}$ & \\
\hline $\begin{array}{l}\text { "Não vejo impedimentos, mas sim obstáculos a serem } \\
\text { vencidos". (M15) }\end{array}$ & \\
\hline
\end{tabular}

Fonte: elaborado pela autora, a partir dos dados da pesquisa em 2015

As respostas dos três entrevistados M07, F12 e M15 revelam que os obstáculos existentes para um trabalho de conscientização da ética na UnB são passíveis de serem vencidos. Nesse contexto, de lidar com o poder, Fischer et al. (2003:08)

Assim, fatores como: superação de obstáculos práticos; resolução de dilemas estratégicos através de um diálogo aberto e regular; demonstração de que estes mecanismos adicionam valor ou trazem benefícios para os participantes e para a sociedade; desenvolvimento de rigorosas ferramentas gerenciais para lidar com os processos e impactos; quando combinados, podem aumentar o potencial das parcerias para a resolução de problemas. [grifo nosso]

Fischer et al., (op.cit.:8) relatam que para a superação das diferenças de uma cultura organizacional, é necessário adotar algumas medidas para a sobre-elevação dos obstáculos práticos, são elas: 
o diálogo aberto e regular; demonstração de que estes mecanismos adicionam valor ou trazem benefícios para os participantes; desenvolvimento de rigorosas ferramentas gerenciais; a combinação das ações pode aumentar o potencial das parcerias para a resolução de problemas.

A frase 'quantidade de departamentos e servidores' no sentido estrito dessas palavras, por apresentarem apenas uma ocorrência ou não repetição nas respostas dos entrevistados, será eliminada do quadro da segunda triagem, conforme quadro a seguir.

\section{Quadro 32. Quadro Geral da Segunda Subdimensão - Questão 4}

\begin{tabular}{|c|c|c|c|}
\hline $\begin{array}{l}\text { Dimensão de } \\
\text { Estudo }\end{array}$ & $\begin{array}{c}\text { Categorias Iniciais } \\
\text { Compostas em Negrito }\end{array}$ & $\begin{array}{c}\text { Categorias } \\
\text { Intermediárias }\end{array}$ & Categorias Finais \\
\hline & & Questão 4 & \\
\hline $\begin{array}{c}\text { Práticas } \\
\text { Educativas e } \\
\text { Instrumentos de } \\
\text { Educação Ética }\end{array}$ & $\begin{array}{l}\text { "Não vejo impedimentos, mas sim } \\
\text { obstáculos a serem vencidos". } \\
\text { (M15) }\end{array}$ & $\begin{array}{c}\text { Obstáculos a serem } \\
\text { vencidos }\end{array}$ & \multirow{3}{*}{$\begin{array}{l}\text { Os motivos, destacados, que } \\
\text { impediriam as ações } \\
\text { educativas na UnB são: } \\
\text { resistência das pessoas em } \\
\text { participar dessas ações e } \\
\text { falta de apoio da } \\
\text { Administração Superior. No } \\
\text { entanto, entende-se que são } \\
\text { obstáculos a serem vencidos. }\end{array}$} \\
\hline $\begin{array}{l}\text { Institucional. } \\
\text { Carneiro et al. } \\
\quad(2002) \\
\text { Szilagyi \& }\end{array}$ & $\begin{array}{l}\text { "Resistência das pessoas em } \\
\text { participar de qualquer tipo de ação } \\
\text { educativa". (F19) }\end{array}$ & $\begin{array}{l}\text { Resistência das } \\
\text { pessoas }\end{array}$ & \\
\hline $\begin{array}{c}\text { Wallace (1980) } \\
\text { aputd Braga } \\
\quad(1987) \\
\text { Freitas (2006) } \\
\text { Matos (2008) } \\
\text { Johann (2009) } \\
\text { Passos (201) }\end{array}$ & $\begin{array}{l}\text { "Acredito que o } \text { principal } \\
\text { empecilho seria a falta de apoio } \\
\text { da Administração superior". } \\
(\mathrm{F} 23)\end{array}$ & $\begin{array}{l}\text { Falta de apoio da } \\
\text { Administração } \\
\text { superior. }\end{array}$ & \\
\hline
\end{tabular}

Fonte: elaborado pela autora, a partir dos dados da pesquisa em 2015.

Após analisar e interpretar os fragmentos de fala de todos os entrevistados, por meio da interpretação por palavras-chaves ou expressões compostas, categorias iniciais, foram 
criadas as intermediárias. A interpretação realiza-se com respaldo na fundamentação teórica desta pesquisa. Já a categoria final é resultado das categorias anteriores, iniciais e intermediárias, constituindo, assim, uma síntese das ideias apresentadas pelos entrevistados, e escrita de forma coerente e coesa para o entendimento geral. Importa salientar que a análise dessas categorias auxilia na compreensão da subdimensão aqui tratada.

De acordo com os autores Carneiro et al., (2002); Braga, (1987); Freitas, (2006); Matos, (2008); Johann (2009); e Passos (2010) esta subdimensão 'Práticas Educativas e Instrumentos de Educação Ética Institucional' revela que, para que haja a implantação de práticas educativas em uma organização, é necessário antes passar por um processo decisório em que a troca de informações (a necessária 'boa comunicação') parece ser vital à sua efetivação (BRAGA, 1987). Esse processo decisório, muitas vezes, ocorre na medida em que as decisões possam ser tomadas de forma individual, em grupo, ou em níveis mais altos “em que os processos decisórios 'estabelecem' as metas e as estratégias organizacionais a serem atingidas" (SZILAGVI \& WALLACE, 1980 apud BRAGA, 1987:36).

Quando ocorre a troca de informações e a decisão é tomada em grupo, a aceitação das ações que serão executadas ocorre de maneira mais consensual. Assim, para que a educação ética ocorra não basta ter somente o marco regulatório, pois a implantação das normas de conduta tem exigências próprias (CARNEIRO et al., 2002). Freitas dá a indicação de quais seriam essas exigências, e a implementação de instrumentos de Gestão da Ética que possam ser bem recepcionados pelos servidores da universidade, de forma que todo o processo possa ser partilhado, também, com os gestores para a sua viabilização.

Não existe moral nem ética de empresa. O que existe é ética de pessoas e são elas que podem alterar o comportamento chamado organizacional. É claro que o comportamento não é um mero decalque do individual, mas uma gestão exercida por pessoas que valorizam um comportamento mais humano, mais responsável e mais honesto e saudável. Tal comportamento tenderá a produzir decisões em que os aspectos éticos serão considerados relevantes (FREITAS, 2006:105). 
Seguindo esta reflexão, em que a gestão ética é compartilhada por pessoas que valorizam um comportamento mais humano, verifica-se que são três os focos fundamentais para o estabelecimento da gestão ética: 1) os valores conscientizados da cultura corporativa; 2) o sistema integrado de liderança; e 3) as estratégias consensuais (MATOS, 2008), em que constata-se a importância de instrumentos de gestão ética que sejam aplicados e capazes de influenciar a conscientização dos integrantes, partícipes, de uma cultura corporativa, a começar pelas lideranças existentes na organização, as quais estão empossadas nos autos cargos e também aquelas que foram constituídas de modo informal pelos funcionários, haja vista essas pessoas terem a capacidade natural de liderança e de influenciar as decisões de um grupo.

Quanto às estratégias consensuais, elas ocorrerão pelo processo decisório de todos os partícipes que executarão as ações. Segundo Matos (2008), para se obter êxito na formulação e na condução das políticas corporativas é imperativo que haja a busca consensual pelo pensamento lógico e o relacionamento harmônico. O autor acrescenta que

\footnotetext{
para que haja a eficácia na aplicação de um novo modelo, deve-se considerar a cultura organizacional, uma vez que ambientes laborais flexíveis sejam mais receptíveis a novos condicionamentos e aceitação de novas políticas. Pouco adianta treinar em tecnologia e doutrinar sobre diretrizes, preceitos, normas, se o ambiente ético funciona como restritivo e inibidor (MATOS, op.cit.:59).
}

Sobre a aproximação entre ética e educação, Johann (2009:83), relata a importância de uma ação efetiva que faça a aproximação entre ética e educação em que "é preciso avançar na busca de uma atividade humana educativa que, de fato, apresente mais plenamente as possibilidades de uma aproximação entre ambas”.

Passos (2010) propõe que sejam realizadas práticas educativas formativas e informativas de modo a proporcionar a conscientização das pessoas, na medida em que elas possam ter espaço para que o assunto seja tratado, entendido e discutido. Matos (2008) 
também propõe algumas ações a serem seguidas para a renovação do ambiente laboral, como por exemplo, rodada de reflexões estratégicas com os gestores e o desafio da ética e outras que já foram listadas na fundamentação teórica deste trabalho.

\subsubsection{Terceira Subdimensão: Gestão da Ética em Relações de Trabalho}

- Aspectos Facilitadores

A última parte dos resultados apresenta a subdimensão 'Gestão da Ética em Relações de Trabalho'. Essa subdimensão foi caracterizada pela quinta pergunta da entrevista estruturada, que tem como propósito listar, por meio das respostas, os aspectos facilitadores e dificultadores para a Gestão da Ética na UnB. Esta pergunta está associada ao objetivo específico: investigar os aspectos facilitadores e dificultadores do processo de trabalho educativo da Comissão de Ética na Universidade. Para o alcance deste objetivo, além do estudo de caso, tem-se também a legislação como contributo favorável e norteador para a enumeração dos aspectos facilitadores da CE/UnB.

A análise da subdimensão "Gestão da Ética em Relações de Trabalho" retratou a resposta à questão 'Em que aspectos, você considera como facilitadores e dificultadores do trabalho da Comissão de Ética na UnB? Justifique'. Foram identificadas oito categorias referentes aos aspectos facilitadores, são elas: profissionais, canais de comunicação, divulgação, ambiente acadêmico, legislação, mediação, reconhecimento, implementação; as quais foram explicadas conforme descrições dispostas nos quadros que seguem. 


\subsubsection{Categoria 'Equipe' - Facilitadores}

Foram revelados na primeira triagem cinco fragmentos em relação ao vocábulo 'equipe'. Todos os fragmentos de resposta da primeira triagem foram codificados por letra e número, em que, por exemplo, ' $\mathrm{M}$ ' representa o gênero do entrevistado e o número ' 16 ' representa a ordem da entrevista. Nesta primeira análise, 'M16' foi escolhido por ser o mais representativo. Assim, buscaram-se isolar padrões repetitivos nos fragmentos codificados por M07, M13, M16, F19 e M20, especificamente em relação ao vocábulo 'equipe', bem como outros que estão associados por estarem dentro do mesmo campo semântico. Em seguida, foi feita a escolha pelo fragmento mais representativo, M16, em relação à categoria, conforme o quadro a seguir.

\section{Quadro 33. Categoria 'Equipe' - Facilitadores}

\begin{tabular}{|c|c|}
\hline Categorial Inicial & Resultado da Categoria Inicial \\
\hline Aspectos Facilitadores & Aspectos Facilitadores \\
\hline "Profissionais capacitados e empenhados". (M07) & \multirow{5}{*}{$\begin{array}{l}\text { “Pessoal qualificado e capaz de implementar } \\
\text { essa conscientização ética na UnB”. (M16) }\end{array}$} \\
\hline $\begin{array}{l}\text { “Quantidade de pessoas para compor a comissão, processo } \\
\text { menos burocrático, 'penalidades' mais leves (apenas } \\
\text { censura)”. (M13) }\end{array}$ & \\
\hline $\begin{array}{l}\text { "Pessoal qualificado e capaz de implementar essa } \\
\text { conscientização ética na UnB”. (M16) }\end{array}$ & \\
\hline $\begin{array}{l}\text { "Mediar uma resolução do problema entre as partes. A } \\
\text { presença de uma secretária que auxilia na dinâmica desse } \\
\text { processo". (F19) }\end{array}$ & \\
\hline "A boa vontade de todos os membros da CE/UnB)". (M20) & \\
\hline
\end{tabular}

Fonte: elaborado pela autora, a partir dos dados da pesquisa em 2015 
Os entrevistados M07, M13, M16, F19 e M20 consideram que um dos aspectos facilitadores para os trabalhos da Comissão de Ética da UnB é a equipe que a compõe, membros e secretária-executiva. Outro aspecto levantado por M13 faz referência 'à quantidade de pessoas que constituem a Comissão', como um aspecto facilitador. M16, por sua vez, afirma que o pessoal que trabalha na comissão é "qualificado e capaz de implementar essa conscientização ética na UnB”. Já F19 relata que "a presença de uma secretária que auxilia na dinâmica desse processo" também é um aspecto facilitador. Por fim, M20 diz que “a boa vontade de todos os membros da Comissão de Ética da UnB facilita a realização de trabalhos da Comissão".

Em relação à equipe que trabalha na Comissão, membros e secretária-executiva, é importante salientar que

\begin{abstract}
a Comissão de Ética tem como finalidade promover valores e princípios prevalentes na sociedade brasileira que reflitam a conduta ética do servidor público federal. A instituição da Secretaria-Executiva formaliza, assim, o processo de institucionalização da ética no serviço público que passa a ser representado na estrutura organizacional do órgão com recursos definidos para a execução das atividades (GONÇALVES \& BILHIN, 2012:4).
\end{abstract}

Acrescenta-se ao exposto, que os 'valores e princípios que a Comissão tem como finalidade promover' está positivado no Código de Ética (Decreto $\mathrm{n}^{\mathrm{o}} 1.171 / 94$ ), quando lembra dos 'valores e princípios prevalentes na sociedade brasileira'.

A institucionalização da Secretaria-Executiva faz-se necessária, haja a vista a secretária ser a única que não possui mandato temporário, como no caso dos membros, o que faz perdurar no tempo uma memória maior dos trabalhos e deliberações das comissões, facilitando, assim, os trabalhos futuros que serão desenvolvidos por novos membros, além de ‘formalizar o processo de institucionalização', conforme já registrado por Gonçalves e Bilhin (2012). 


\subsubsection{Categoria 'Canais de Comunicação' - Facilitadores}

Dentro do campo semântico de 'canais de comunicação' foram encontrados os seguintes fragmentos de respostas, F02 e F09, sendo que o mais representativo foi F09, conforme pode-se observar no quadro que segue.

Quadro 34. Categoria 'Canais de Comunicação' - Facilitadores

\begin{tabular}{|c|c|}
\hline \multicolumn{1}{|c|}{ Categorial Inicial } & Resultado da Categoria Inicial \\
\hline \multicolumn{1}{|c|}{ Aspectos Facilitadores } & \multicolumn{1}{|c|}{ Aspectos Facilitadores } \\
\hline $\begin{array}{l}\text { "Site bem construído detalhando o trabalho da CE na } \\
\text { UnB". (F02) }\end{array}$ & $\begin{array}{l}\text { "Legislação, código de ética, participação da } \\
\text { Ouvidoria, lei de acesso à informação, canais de } \\
\text { comunicação, ambiente com diversidades". (F09) }\end{array}$ \\
$\begin{array}{l}\text { "Legislação, código de ética, participação da } \\
\text { comunidoria, lei de acesso à informação, canais de }\end{array}$ \\
\hline
\end{tabular}

Fonte: elaborado pela autora, a partir dos dados da pesquisa em 2015

F02 e F09 relatam que ‘canais de comunicação' da Comissão de Ética facilitam os trabalhos da comissão, em relação a esses canais de comunicação que são disponibilizados. Por exemplo, tem-se um site, recentemente reformulado, para melhor atender à comunidade universitária, e que, segundo F02, é um "site bem construído detalhando o trabalho da CE/UnB. F09. Essa foi, por sua vez, escolhida como a fala mais representativa, uma vez que abarca nas palavras 'canais de comunicação', e todas as outras palavras citadas e pertencentes ao mesmo campo semântico, como, por exemplo, 'site'. 
Em relação aos canais de comunicação em uma organização, Kunsch (2003:90)

registra que

as organizações têm de se valer de serviços integrados nessa área, pautando-se por políticas que privilegiem o estabelecimento de canais de comunicação com os públicos vinculados. A abertura de fontes e a transparência das ações serão fundamentais para que as organizações possam se relacionar com a sociedade e contribuir para a construção da cidadania na perspectiva da responsabilidade social.

O site da Comissão de Ética busca atender essa necessidade de transparência das ações, bem como a abertura de mais um canal de comunicação, além do recebimento de correspondências, atendimento via telefone, e recepção na Secretaria da Comissão pela Secretária-Executiva.

\subsubsection{Categoria 'Divulgação' - Facilitadores}

O vocábulo 'divulgação' teve duas ocorrências em F03 e F23, em que F23 é mais representativo, conforme quadro a seguir.

\section{Quadro 35. Categoria 'Divulgação' - Facilitadores}

\begin{tabular}{|c|c|}
\hline \multicolumn{1}{|c|}{ Categorial Inicial } & \multicolumn{1}{|c|}{ Resultado da Categoria Inicial } \\
\hline \multicolumn{1}{|c|}{ Aspectos Facilitadores } & Aspectos Facilitadores \\
\hline $\begin{array}{l}\text { "Não visualizo um facilitador, talvez a divulgação da } \\
\text { existência". (F03) }\end{array}$ & $\begin{array}{l}\text { "Divulgação dos serviços prestados [...]". } \\
\text { (F23) }\end{array}$ \\
\hline "Divulgação dos serviços prestados[...]". (F23)
\end{tabular}

Fonte: elaborado pela autora, a partir dos dados da pesquisa em 2015

Os entrevistados F03 e F23 salientam a importância de divulgar a Comissão de Ética na universidade, como forma de facilitar os trabalhos da comissão, em relação a divulgar os atos públicos. Kant apud Bobbio e Nogueira (1997:28) afirma que "todas as ações 
relativas ao direito de outros homens, cuja máxima não é suscetível de se tornar pública, são injustas". Soares (2007:65), por sua vez, acrescenta que "a lei inclusive impõe ao administrador público o dever de publicar" os atos. A publicidade no âmbito dos órgãos públicos é exigência expressa da Constituição Brasileira, em diversos dispositivos, e quando se fala em 'publicidade', nessa seara do conhecimento, refere-se ao 'ato de divulgar, de tornar público'. Portanto, é obrigação da Comissão de Ética divulgar seus atos. A criação do site tem justo esta intenção de melhor atender aos demandantes. Entretanto, faz-se necessária a divulgação por toda a universidade de um modo mais incisivo e, portanto presencial que possa alcançar o maior número de pessoas com informação direta.

\subsubsection{Categoria ‘Ambiente Acadêmico' - Facilitadores}

Dentro do campo semântico de 'ambiente acadêmico' foram encontrados dois registros, F04 e F05, dos quais F05 é mais representativo, conforme evidencia o quadro a seguir.

\section{Quadro 36. Categoria 'Ambiente Acadêmico' - Facilitadores}

\begin{tabular}{|c|c|}
\hline \multicolumn{1}{|c|}{ Categorial Inicial } & \multicolumn{1}{|c|}{ Resultado da Categoria Inicial } \\
\hline \multicolumn{1}{|c|}{ Aspectos Facilitadores } & \multicolumn{1}{|c|}{ Aspectos Facilitadores } \\
\hline $\begin{array}{l}\text { “Ambiente acadêmico em que todos estão inseridos". } \\
\text { (F04) }\end{array}$ & $\begin{array}{l}\text { “[...] local de trabalho ser próprio para educação, } \\
\text { ensino e extensão". (F05) }\end{array}$ \\
\hline $\begin{array}{l}\text { "[...] local de trabalho ser próprio para educação, } \\
\text { ensino e extensão". (F05) }\end{array}$ & \\
\hline
\end{tabular}

Fonte: elaborado pela autora, a partir dos dados da pesquisa em 2015

F04 e F05 declaram que o ambiente acadêmico por ser um local de trabalho próprio para a educação, ensino e extensão" é um facilitador para os trabalhos da comissão. A esse respeito pesquisou-se no Estatuto e Regimento Geral da UnB e verificou-se que 


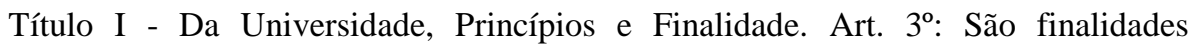
essenciais da Universidade de Brasília o ensino, a pesquisa e a extensão, integrados na formação de cidadãos qualificados para o exercício profissional e empenhados na busca de soluções democráticas para os problemas nacionais (UNB, 2008).

Do exposto, verifica-se uma afinidade deste estudo com as finalidades essenciais da UnB e concordância com a fala de F05, motivo pelo qual foi escolhido como a fala mais representativa.

\subsubsection{Categoria 'Legislação' - Facilitadores}

Dentro do campo semântico do vocábulo 'legislação' foram encontrados quatro registros, F09, M13, M15 e M22, dos quais F09 é o mais representativo, conforme quadro a seguir.

\section{Quadro 37. Categoria 'Legislação' - Facilitadores}

\begin{tabular}{|c|c|}
\hline Categorial Inicial & Resultado da Categoria Inicial \\
\hline Aspectos Facilitadores & Aspectos Facilitadores \\
\hline $\begin{array}{l}\text { "Legislação, código de ética, participação da } \\
\text { Ouvidoria, lei de acesso a informação, canais de } \\
\text { comunicação, ambiente com diversidades". (F09) }\end{array}$ & \multirow{3}{*}{$\begin{array}{l}\text { "Legislação, código de ética, participação da } \\
\text { Ouvidoria, lei de acesso a informação, canais de } \\
\text { comunicação, ambiente com diversidades". (F09) }\end{array}$} \\
\hline $\begin{array}{l}\text { "Casos menos graves que os disciplinares; processos } \\
\text { mais subjetivos (rito, forma)". (M15) }\end{array}$ & \\
\hline $\begin{array}{l}\text { "[...] menor formalidade [...] a norma traz poder de } \\
\text { ação a esta Comissão". (M22) }\end{array}$ & \\
\hline $\begin{array}{l}\text { "Quantidade de pessoas para compor a Comissão, } \\
\text { processo menos burocrático, 'penalidades' mais } \\
\text { leves (apenas censura)". (M13) }\end{array}$ & \\
\hline
\end{tabular}

Fonte: elaborado pela autora, a partir dos dados da pesquisa em 2015 
Os entrevistados F09, M15, M22 afirmaram que a legislação é um aspecto facilitador para os trabalhos da Comissão de Ética da UnB, ao passo que F09 acrescenta a participação da Ouvidoria nos trabalhos da comissão, bem como a Lei de Acesso à Informação como facilitadores desse trabalho. Em relação à Ouvidoria, trata-se de

um serviço disponibilizado pela Universidade de Brasília para garantir a efetiva comunicação entre o/a manifestante e os diversos órgãos da UnB, recepcionando e encaminhando sugestões, reclamações, denúncias, pedidos de informação e elogios da comunidade universitária e da sociedade em geral (UNB, 2015 (b).

A participação da ouvidoria pode ser notada quando encaminha reclamações e denúncias para a Comissão de Ética, bem como o Decanato de Gestão de Pessoas e o Gabinete do Reitor, entre outros departamentos da universidade.

Em relação à lei de Acesso à Informação $n^{\circ}$ 12.527/2011 que regulamenta o direito constitucional de acesso às informações públicas, tem-se que a norma entrou em vigor em 16 de maio de 2012 e criou mecanismos que possibilitam, a qualquer pessoa, física ou jurídica, sem necessidade de apresentar motivo, o recebimento de informação pública dos órgãos e entidades" (BRASIL, 2015). Em relação a essa lei, é uma contribuição para o estabelecimento da transparência, e em sequência, da ética em órgãos públicos de modo a fazer com que estes órgãos cumpram com a determinação legal.

Quando M15 afirma que os "casos são menos graves que os disciplinares, processos mais subjetivos", ele se refere às penas aplicáveis pela CPAD, podendo chegar a exonerações e demissões. Lembra-se que a penalidade mais grave da Comissão de Ética é a 'censura' haja vista a finalidade da comissão de educar para a ética. Quanto ao fato de os processos serem subjetivos, esta fala não encontra respaldo legal, haja vista os processos que tramitam na Comissão de Ética obedecerem às normas de funcionamento e de rito processual disciplinados pela Resolução ${ }^{\circ} 10$, de 29 de setembro de 2008, o que corrobora com a fala de M22, quando diz que "[...] a norma traz poder de ação a esta comissão". 
Quanto à legislação da comissão, a qual se encontra disponível em seu site, são citadas as seguintes: Decreto $\mathrm{n}^{\mathrm{o}} 1.171 / 1994$ - Código de Ética Profissional do Servidor Público Civil do Poder Executivo Federal; o Código de Conduta - Servidor da UnB, que, por estar em processo de análise e aprovação, não será aqui considerado; Decreto nº 6.029/2007 Sistema de Gestão da Ética no Poder Executivo Federal; Resolução n ${ }^{\circ}$. 10/2008 da CEP; e de forma subsidiária, a Comissão se pauta também na Lei n ${ }^{\circ} .8424 / 1992$ - Lei de Improbidade; Lei nº 9.784/1999 - Processo Administrativo no âmbito da Administração Pública Federal; Lei no . 8.112/1990 - Regime Jurídico dos Servidores Públicos Civis da União; bem como de Códigos e outras leis que lhe sejam pertinentes, para dirimir dúvidas e suprir lacunas de sua legislação principal.

\subsubsection{Categoria 'Mediação' - Facilitadores}

Em relação ao vocábulo 'mediação' foram encontrados dois registros: F19 e F21, dos quais F19 é mais representativo.

Quadro 38. Categoria 'Mediação' - Facilitadores

\begin{tabular}{|c|c|}
\hline \multicolumn{1}{|c|}{ Categorial Inicial } & \multicolumn{1}{|c|}{ Resultado da Categoria Inicial } \\
\hline \multicolumn{1}{|c|}{ Aspectos Facilitadores } & \multicolumn{1}{|c|}{ Aspectos Facilitadores } \\
\hline $\begin{array}{l}\text { "Mediar uma resolução do problema entre as partes. } \\
\text { A presença de uma secretária que auxilia na dinâmica } \\
\text { desse processo". (F19) }\end{array}$ & $\begin{array}{l}\text { "Mediar uma resolução do problema entre as } \\
\text { partes". A presença de uma secretária que auxilia na } \\
\text { dinâmica desse processo". (F19) }\end{array}$ \\
\hline $\begin{array}{l}\text { "[...] instância de conversa para a mediação de } \\
\text { conflitos". (F21) }\end{array}$ & \\
\hline
\end{tabular}

Fonte: elaborado pela autora, a partir dos dados da pesquisa em 2015 
Os entrevistados F19 e F21 relataram que o fato de a comissão mediar uma resolução de problemas entre as partes configura-se como um aspecto facilitador para os trabalhos da comissão. Em relação à essa mediação, o Regimento Interno da Comissão de Ética, que tem como finalidade regulamentar as disposições relativas à Comissão de Ética local, no âmbito da Universidade de Brasília, de acordo com o Código de Conduta do Servidor Público Civil do Poder Executivo Federal e do Decreto nº 6029/2007, no que tange a competência, estrutura organizacional, atribuições, deveres e responsabilidades de seus membros, funcionamento e disposições gerais, reza o seguinte:

\footnotetext{
Capitulo V - Competências - Art. 10 - Compete à Comissão de Ética, no âmbito da Universidade de Brasília:

II - Atuar como instância consultiva de dirigentes e servidores no âmbito da Universidade de Brasília;

IV - Aconselhar sobre a ética profissional do Servidor Público no trato com pessoas e com o patrimônio público, com vistas ao fortalecimento da ética pública e ao restabelecimento da confiança nas instituições públicas;

VI - Orientar os servidores no sentido de adotar uma conduta conforme os princípios reitores da Administração Pública; inspirando o respeito pelos seus pares e pelo Serviço Público;

XII - propor Acordo de Conduta Pessoal e Profissional.
}

Do exposto, o Regimento Interno dá sustentação para que a Comissão de Ética da UnB possa intervir para a resolução de lides.

\subsubsection{Categoria 'Reconhecimento' - Facilitadores}

Dentro do campo semântico do vocábulo 'reconhecimento' foram encontrados dois fragmentos de resposta, M01 e F11, dos quais F11 é o mais representativo, conforme quadro a seguir. 
Quadro 39. Categoria 'Reconhecimento' - Facilitadores

\begin{tabular}{|c|c|}
\hline Categorial Inicial & Resultado da Categoria Inicial \\
\hline Aspectos Facilitadores & Aspectos Facilitadores \\
\hline $\begin{array}{l}\text { "Reconhecimento }[\ldots] \text { das pessoas }[\ldots] \text { investimentos } \\
\text { nessa área". (M01) }\end{array}$ & "A crescente importância da ética na sociedade \\
\hline $\begin{array}{l}\text { "A crescente importância da ética na sociedade atual } \\
{[\ldots] " .(F 11)}\end{array}$ & atual $[\ldots] \cdot \cdot(\mathrm{F} T 1)$ \\
\hline
\end{tabular}

Fonte: elaborado pela autora, a partir dos dados da pesquisa em 2015

Os entrevistados M01 e F11 alegam que "a crescente importância na sociedade atual", logo seu "reconhecimento" em relação ao tema ética, é facilitadora para os trabalhos da comissão. A esse respeito, Iyer (2013) registra que numa “crescente importância do tema ética, verifica-se a criação de órgãos de controle, comissões, ouvidorias [...], trabalhando com a questão da ética, através da transparência de informações, que em tempos remotos, o cidadão não tinha o referido acesso", no caso do Brasil, em relação à Comissão de Ética, de acordo com IYER (2013), pós-impeachment do Presidente Fernando Collor de Mello, em que o escândalo no Brasil potencializou a desconfiança do cidadão brasileiro em relação ao serviço público. Para iniciar uma reforma gerencial, o Presidente Fernando Henrique Cardoso adotou algumas medidas, dentre elas a criação da Comissão de Ética Pública da Presidência da República - CEP/PR, para lidar com as tensões éticas existentes. Com esta criação adveio os normativos necessários para a efetivação da gestão ética nacional. Todavia, Mendes relata que

não obstante, existe uma crescente mudança no sentido da conscientização para a ética, perceptível tanto para os servidores públicos quanto para a sociedade organizada. O fato não pode ser atribuído exclusivamente ao Sistema de Gestão da Ética. É o conjunto de ações com diferentes atores e políticas que está promovendo mudanças incrementais (MENDES, 2014:6). 


\subsubsection{Categoria 'Implementação' - Facilitadores}

O vocábulo 'implementação' aparece em dois fragmentos de respostas, M14 e M16, dos quais M14 é o mais representativo, conforme mostra o quadro a seguir.

Quadro 40. Categoria 'Implementação' - Facilitadores

\begin{tabular}{|c|c|}
\hline \multicolumn{1}{|c|}{ Categorial Inicial } & Resultado da Categoria Inicial \\
\hline \multicolumn{1}{|c|}{ Aspectos Facilitadores } & Aspectos Facilitadores \\
\hline $\begin{array}{l}\text { "[...] atitudes para implementação e manutenção do } \\
\text { sistema de trabalho". (M14) }\end{array}$ & $\begin{array}{l}\text { "[...] atitudes para implementação e manutenção do } \\
\text { sistema de trabalho". (M14) }\end{array}$ \\
$\begin{array}{l}\text { "Pessoal qualificado e capaz de implementar essa } \\
\text { conscientização ética na UnB". (M16) }\end{array}$ & \\
\hline
\end{tabular}

Fonte: elaborado pela autora, a partir dos dados da pesquisa em 2015

M14 e M16 afirmam que um aspecto facilitador para os trabalhos da comissão é implementar um sistema de trabalho e a sua manutenção. Em relação a essa afirmação, Fonseca (1997:14), observa que "o sucesso e a sobrevivência das organizações são atingidas, se estes se adaptarem ao seu meio envolvente e se forem capazes de manter um equilíbrio estável naquele enquadramento". Dessa forma, para alcançar o sucesso, bem como a sobrevivência, não basta apenas implementar e adaptar ao meio; é necessária a "manutenção do sistema de trabalho", conforme revela M14. 
Quadro 41. Quadro Geral da terceira Subdimensão (Questão 5 - Facilitadores)

\begin{tabular}{|c|c|c|c|}
\hline $\begin{array}{l}\text { Dimensão de } \\
\text { Estudo }\end{array}$ & $\begin{array}{l}\text { Categorias Iniciais } \\
\text { Trechos e Expressões } \\
\text { Compostas em Negrito }\end{array}$ & $\begin{array}{c}\text { Categorias } \\
\text { Intermediárias }\end{array}$ & Categorias Finais \\
\hline & Aspectos Facilitadores & $\begin{array}{c}\text { Aspectos } \\
\text { Facilitadores }\end{array}$ & \\
\hline \multirow{7}{*}{$\begin{array}{c}\text { Gestão da Ética } \\
\text { em relações de } \\
\text { trabalho Brasil } \\
\text { (1994); Brasil } \\
\text { (2007); Brasil } \\
\text { (2008); } \\
\text { Bergami e } \\
\text { Beraldo (2010); } \\
\text { Chagas (2010); } \\
\text { Matos (2008); } \\
\text { Passos (2010); } \\
\text { Puig (1988) e } \\
\text { Soares (2002); } \\
\text { Mendes (2014) }\end{array}$} & $\begin{array}{l}\text { "[...] local de trabalho } \\
\text { ser próprio para } \\
\text { educação, ensino e } \\
\text { extensão". (F05) }\end{array}$ & $\begin{array}{l}\text { Local de trabalho ser } \\
\text { próprio para a } \\
\text { educação }\end{array}$ & \multirow{7}{*}{$\begin{array}{l}\text { Os aspectos facilitadores destacados } \\
\text { são: comissão de ética composta por } \\
\text { pessoal qualificado; canais } \\
\text { disponíveis de comunicação; local } \\
\text { de trabalho ser próprio para a } \\
\text { educação; a crescente importância } \\
\text { do tema 'ética' na sociedade, pela } \\
\text { legislação, ao mediar os conflitos e } \\
\text { em ter atitudes para implementação } \\
\text { e divulgação dos serviços. }\end{array}$} \\
\hline & $\begin{array}{l}\text { "Legislação, código de } \\
\text { ética, participação da } \\
\text { Ouvidoria, lei de acesso } \\
\text { a informação, canais de } \\
\text { comunicação, ambiente } \\
\text { com diversidades". (F09) }\end{array}$ & $\begin{array}{l}\text { Canais de } \\
\text { comunicação; } \\
\text { Legislação }\end{array}$ & \\
\hline & $\begin{array}{l}\text { "A crescente } \\
\text { importância da ética na } \\
\text { sociedade atual...". (F11) }\end{array}$ & $\begin{array}{c}\text { Crescente importância } \\
\text { da ética }\end{array}$ & \\
\hline & $\begin{array}{l}\text { "[...] atitudes } \\
\text { implementação } \\
\text { manutenção do sistema } \\
\text { de trabalho". (M14) }\end{array}$ & Implementação & \\
\hline & $\begin{array}{l}\text { "Pessoal qualificado e } \\
\text { capaz de implementar } \\
\text { essa conscientização } \\
\text { ética na UnB". (M16) }\end{array}$ & Pessoal qualificado & \\
\hline & $\begin{array}{l}\text { "Mediar uma resolução } \\
\text { do problema entre as } \\
\text { partes. A presença de } \\
\text { uma secretária que } \\
\text { auxilie na dinâmica } \\
\text { desse processo". (F19) }\end{array}$ & Mediação & \\
\hline & $\begin{array}{l}\text { "Divulgação } \quad \text { dos } \\
\text { serviços prestados..." } \\
\text { (F23) }\end{array}$ & Divulgação & \\
\hline
\end{tabular}

Fonte: elaborado pela autora, a partir dos dados da pesquisa em 2015

Após analisar e interpretar os fragmentos de fala de todos os entrevistados, por meio da interpretação por palavras-chave ou expressões compostas que emergiram das 
categorias iniciais, foram compostas as categorias intermediárias. A interpretação realizou-se com base no referencial teórico da pesquisa realizada. Já a categoria final é resultado das categorias anteriores, constituindo uma síntese das ideias apresentadas pelos entrevistados, e assim escrita de forma coerente e coesa para o entendimento geral. É importante salientar que as análises dessas categorias auxiliam na compreensão da subdimensão aqui tratada.

Abaixo, seguem as considerações dos autores citados no decorrer deste estudo, principalmente na fundamentação teórica, sobre esta dimensão de estudo.

“O termo Gestão da Ética é utilizado para denominar a política pública para a promoção da ética" (MENDES, 2014:16). O Sistema de Gestão da Ética do Poder Executivo Federal é um sistema mais abrangente, haja vista partir da Comissão de Ética da Presidência da República - CEP/PR para as Comissões de Ética locais. A esse respeito, Almeida (2007:69) diz que "[...] para os sistemas formais influenciarem o comportamento, eles devem ser parte de um sistema mais abrangente, culturalmente coordenado, que apoie a conduta ética em cada momento". Esta citação aplica-se em parte, ao caso concreto das comissões de ética locais, haja vista elas terem autonomia em suas deliberações. Assim, não há que se falar de um controle finalístico por parte da CEP/PR, além do que, este também não se trata de um órgão recursal dessas comissões locais.

Verifica-se a necessidade do Sistema de Gestão da Ética, posto que "a maioria das pessoas é o produto do contexto ao qual descobrem pertencer. Elas tendem a olhar para cima e para os lados, e fazem o que os outros ao redor fazem ou esperam que elas façam" (ALMEIDA, 2007:69).

Matos (2008:122) faz algumas recomendações essenciais ao modelo de Gestão da Ética. O autor diz ser necessário definir a filosofia da empresa quando afirma ser “imprescindível que todos na empresa tenham plena consciência dos valores fundamentais 
que orientam os comportamentos. Significa tornar palpáveis os traços fundamentais da cultura corporativa". Em segundo lugar, Matos (2008) diz ser necessário “definir as diretrizes éticas. Explicitar os padrões de comportamento esperados, consoante aos valores da cultura corporativa". A esse respeito, o Código de Ética, (Decreto $\mathrm{n}^{0}$ 1.171/94), cumpre tal direcionamento.

Em terceiro lugar, Matos recomenda criar instrumentos institucionais para a gestão da ética. O autor acrescenta que "a viabilização do comportamento ético depende fortemente da instituição de meios adequados. Sem os espaços à reflexão e ao exercício participativo da decisão, a gestão torna-se centralizadora e autocrática. Nesses casos, a cultura corporativa fechada inibe a gestão da ética” (MATOS, 2008:122).

No que se refere à cultura corporativa fechada, esse aspecto é um dificultador dos trabalhos, mas o fato de a Comissão de Ética contar com sua instituição por Decreto Presidencial n ${ }^{0}$ 6.029/2007 já abre possibilidades para uma inserção nessa cultura 'fechada'.

Por último, Matos (op.cit.:122), revela ser importante “desenvolver continuamente a consciência ética por meio da educação". Assim, verifica-se a importância desse estudo, haja vista ser esta a principal meta, a qual é recomendação essencial ao modelo de Gestão da Ética. Em relação a essa última orientação, Matos (op.cit.) diz ser necessários "exercícios permanentes de percepção e competência criativas por intermédio de técnicas e metodologias dinâmicas de aprendizagem que reforcem os valores e a práxis da ética no trabalho, contribuindo para a consolidação de uma cultura corporativa aberta”.

\section{- Aspectos Dificultadores}

A análise da dimensão 'Gestão da Ética em Relações de Trabalho' retratou a resposta à questão 'em que aspectos você considera como facilitadores e dificultadores do 
trabalho da Comissão de Ética na UnB? Justifique'. Foram identificadas cinco categorias, referentes aos 'aspectos dificultadores': falta de apoio da administração superior; espaço físico; equipe; marco regulatório frágil; dificuldades do trabalho em equipe; as quais foram explicadas conforme descrições dispostas nos quadros que se seguem.

\subsubsection{Categoria 'Falta de Apoio da Administração Superior' - Dificultadores}

Foram revelados, na primeira triagem, cinco fragmentos em relação à frase 'falta de apoio da Administração Superior'. Todos os fragmentos de resposta da primeira triagem foram codificados por letra e número, em que, por exemplo, ' $F$ ' representa o gênero do entrevistado e o número '23', a ordem da entrevista, nessa primeira análise. Buscou-se isolar padrões repetitivos nos fragmentos codificados por M01, F09, M20 e F23, especificamente, em relação às expressões de mesmo campo semântico de 'Falta de apoio da Administração Superior', e, em seguida, foi feita a escolha pelo fragmento mais representativo, F23, em relação à categoria teórica, conforme pode ser visto no Quadro 42.

Quadro 42. Categoria 'Falta de Apoio da Administração Superior' - Dificultadores

\begin{tabular}{|c|c|}
\hline Categorial Inicial & Resultado da Categoria Inicial \\
\hline Aspectos Dificultadores & Aspectos Dificultadores \\
\hline "Vontade de nossos administradores". (M01) & \multirow{4}{*}{$\begin{array}{l}\text { "Falta de apoio da Administração Superior } \\
\text { que é fundamental". (F23) }\end{array}$} \\
\hline "Poder das autoridades, questões políticas". (F09) & \\
\hline $\begin{array}{l}\text { "Mais premente é falta de um local físico, como uma sala } \\
\text { para que o trabalho seja conduzido". (M20) }\end{array}$ & \\
\hline $\begin{array}{l}\text { "Falta de apoio da Administração Superior que é } \\
\text { fundamental". (F23) }\end{array}$ & \\
\hline
\end{tabular}

Fonte: elaborado pela autora, a partir dos dados da pesquisa em 2015 
Os entrevistados M01, F09, M20 e F23 declararam que falta apoio da Administração Superior, seja através da fala de M01 ao dizer que um aspecto dificultador é a "vontade de nossos administradores", ou "Poder das autoridades, questões políticas", conforme F09, seja pela "falta de um local físico" disponibilizado pela Administração Superior, na fala de M20. A resposta que arremata todas as anteriores e que foi escolhida como a mais representativa é a "falta de apoio da Administração Superior que é fundamental", dita por F23.

Em relação a essa falta de apoio, alguns autores dizem que "a gestão ética e o desempenho social das organizações pode efetivamente constituir, ainda que parcialmente, um reflexo da maturidade moral dos seus dirigentes" (TREVIÑO \& BROWN, 2005:112), o que corrobora com a afirmação de Carrol (apud MEIRA, 2010:15), quando diz que "enquanto os dirigentes não abraçarem completamente os conceitos da gerência moral, a transformação cultural nas empresas, que é essencial para o florescimento da gestão ética, não irá acontecer”.

É certo que há uma forte influência dos dirigentes sobre a cultura nas empresas, e com isso "os empregados devem ser "levados" para a ética a partir do topo, da mesma forma que devem ser levados em matéria de qualidade, competitividade e a um conjunto de outros comportamentos esperados" (TREVIÑO \& BROWN, 2005:74).

\subsubsection{Categoria 'Espaço Físico' - Dificultadores}

'Espaço físico' apareceu em quatro fragmentos de respostas, F02, F03, M20, M13, dos quais M20 é o mais representativo, conforme pode ser visto no Quadro 43. 


\begin{tabular}{|c|c|}
\hline Categorial Inicial & Resultado da Categoria Inicial \\
\hline Aspectos Dificultadores & Aspectos Dificultadores \\
\hline $\begin{array}{l}\text { "Acesso restrito, necessário ir ao Gabinete do Reitor- } \\
\text { GRE, lugar bem visível". (F02) }\end{array}$ & \multirow{4}{*}{$\begin{array}{l}\text { "Mais premente é falta de um local físico, como uma } \\
\text { sala para que o trabalho seja conduzido". (M20) }\end{array}$} \\
\hline “Localização junto ao GRE”. (F03) & \\
\hline "Matéria subjetiva, espaço físico". (M13) & \\
\hline $\begin{array}{l}\text { "Mais premente é falta de um local físico, como uma } \\
\text { sala para que o trabalho seja conduzido". (M20) }\end{array}$ & \\
\hline
\end{tabular}

Fonte: elaborado pela autora, a partir dos dados da pesquisa em 2015

Os entrevistados F02, F03, M20, M13 relataram que um aspecto dificultador é a falta de um local físico que seja adequado aos trabalhos da Comissão, não só no que diz respeito à sua localização, mas também quanto ao seu espaço físico. Atualmente, o layout do espaço físico, em que se encontra a secretaria da comissão, constitui um fator crítico para a realização de atendimentos à comunidade universitária. A sala onde a secretaria da comissão está situada é dividida com outra servidora que trabalha para o gabinete do reitor.

Além do mais, não dispõe de "espaço físico para as pessoas, espaço para o material de trabalho, iluminação, mobiliário, silêncio e temperatura adequada". Faria e Alencar (1996:52) relacionam que esses aspectos são fundamentais para a dignidade da qualidade do ambiente e do trabalho, como é o caso de necessidade da secretaria da comissão, posto que não é adequado para receber as pessoas, realizar reuniões e abrigar o seu arquivo permanente. Os autores falam ainda que um ambiente de trabalho é que estimula a criatividade para o trabalho.

A esse respeito já foram encaminhados ofícios formalizando o pedido de sala exclusiva e adequada para a realização dos trabalhos, porém a resposta obtida é que não há 
espaço físico. Verificou-se que o problema de espaço é de toda a UnB, em que departamentos administrativos, alunos e docentes compartilham dessa mesma dificuldade.

\subsubsection{Categoria 'Servidores da UnB' - Dificultadores}

'Servidores da UnB' apareceu em dois fragmentos F05 e F18, dos quais F18 é mais representativo, conforme exposto no quadro a seguir.

Quadro 44. Categoria 'Servidores da UnB - Dificultadores

\begin{tabular}{|c|c|}
\hline Categorial Inicial & Resultado da Categoria Inicial \\
\hline Aspectos Dificultadores & Aspectos Dificultadores \\
\hline $\begin{array}{l}\text { "[...] dispersão territorial dos servidores, diferenças } \\
\text { de relações entre chefias". (F05) }\end{array}$ & "Administrar um trabalho que envolve grande \\
\hline $\begin{array}{l}\text { "Administrar um trabalho que envolve grande } \\
\text { número de servidores que compõe os recursos } \\
\text { humanos da UnB". (F18) }\end{array}$ & $\begin{array}{l}\text { número de servidores que compõe os recursos } \\
\text { humanos da UnB". (F18) }\end{array}$ \\
\hline
\end{tabular}

Fonte: elaborado pela autora, a partir dos dados da pesquisa em 2015

Os entrevistados F05 e F18 afirmam que o grande número de servidores que compõe os recursos humanos da UnB, bem como a sua dispersão territorial no âmbito da universidade, são aspectos dificultadores para a realização dos trabalhos da comissão. A respeito dos indivíduos que compõem uma organização, Motta (1996, apud HOFSTEDE 2010:5) revela que o individualismo ocorre nas situações em que as pessoas se definem como indivíduos, o que implica em redes sociais que se interligam difusamente. Nessas redes, as pessoas tomam conta apenas de si próprias e daqueles que lhe estão mais próximos. 
Do exposto, verifica-se a necessidade de implementar ações educativas para as pessoas desse grupo, através de ações online, por exemplo, que lhe permitam adequar seu estudo em um melhor horário dentro de sua agenda, além de abarcar esse grande número de servidores de forma mais prática. Outra situação revelada por Hofstede; Hofstede e Minkov é o coletivismo, conforme o que segue:

a situação inversa, o coletivismo, é caracterizada por redes sociais profundas nas quais as pessoas fazem uma distinção entre seus próprios grupos. É o caso em que as pessoas esperam que seus grupos deem proteção a seus membros fornecendo-lhes segurança em troca de lealdade (HOFSTEDE, HOFSTEDE \& MINKOV, 2010:5).

Em relação ao coletivismo, verifica-se que as ações a serem implementadas para esses grupos devem citar a segurança proporcionada às partes, demandante e demandado, em que fiquem cientes de seus direitos junto à Comissão de Ética e de como funciona o rito, inclusive quanto à chancela de reservado, que visa ao sigilo das informações. Hofstede, Hofstede e Minkov (2010) acrescentam ao exposto, a ideia de que em duas orientações, liberdade individual e proteção coletiva, ambas estão sempre em jogo. É quase sempre possível, ao agir, perguntar se estou fazendo o melhor, seja para mim, seja para o meu grupo".

Essas informações de individualismo e coletivismo os referidos autores utilizaram para explicar a cultura de organizações de um país. Entretanto, podem ser trazidas para o contexto de uma organização governamental. Disso apura-se que as ações de educação para ambos os grupos devem levar em conta as características existentes dentro de uma instituição, de modo que a ação a ser executada seja eficaz.

\subsubsection{Categoria 'Marco Regulatório Frágil - Dificultadores}


Foram encontrados três fragmentos em relação ao campo semântico da frase 'Marco regulatório frágil' nos registros de M13, F21 e M22, dos quais M22 é o mais representativo. Acompanhar o quadro a seguir.

Quadro 45. Categoria 'Marco Regulatório Frágil' - Dificultadores

\begin{tabular}{|c|c|}
\hline Categorial Inicial & Resultado da Categoria Inicial \\
\hline Aspectos Dificultadores & Aspectos Dificultadores \\
\hline "Matéria subjetiva, espaço físico". (M13) & \multirow{3}{*}{$\begin{array}{l}\text { "Precariedade do sistema normativo, como um } \\
\text { Decreto que enseja, em casos mais sérios, a } \\
\text { judicialização das atividades". (M22) }\end{array}$} \\
\hline “[...] O marco regulatório é frágil”. (F21) & \\
\hline $\begin{array}{l}\text { "Precariedade do sistema normativo, como um } \\
\text { Decreto que enseja, em casos mais sérios, a } \\
\text { judicialização das atividades". (M22) }\end{array}$ & \\
\hline
\end{tabular}

Fonte: elaborado pela autora, a partir dos dados da pesquisa em 2015

Os entrevistados M13, F21 e M22 alegam, de um modo geral, que o marco regulatório é frágil, haja vista a matéria ser subjetiva. Na fala de M13 não se encontra respaldo legal, posto que os processos que tramitam na Comissão de Ética obedecem às normas de funcionamento e o rito processual disciplinados pela Resolução $\mathrm{n}^{\circ} 10$, de 29 de setembro de 2008. Por sua vez, quando F21 e M22 afirmam que o marco regulatório é frágil e há precariedade do sistema normativo, haja vista as brechas da legislação, como, por exemplo, o fato de as punições dos servidores públicos federais já estar discriminadas na Lei 8.112/90 esta dispõe sobre o regime jurídico dos servidores públicos civis da União, das autarquias e das fundações públicas federais -, e a pena de censura não ter sido contemplada nesta lei. Esta é a justificativa utilizada por advogados para a 'judicialização das atividades’ da Comissão de Ética, conforme fala M22 sobre a Comissão de Ética/UnB, ao passo que não houve um só 
processo finalizado até o presente momento na esfera judiciária, com causa ganha, contra a Comissão de Ética da UnB.

\subsubsection{Categoria 'Dificuldades do Trabalho em Equipe' - Dificultadores}

Dentro do campo semântico de 'dificuldades do trabalho em equipe' foram encontrados dois registros, F05 e M14, dos quais M14 é mais representativo, conforme observa-se no próximo quadro.

Quadro 46. Categoria 'Dificuldades do Trabalho em Equipe' - Dificultadores

\begin{tabular}{|c|c|}
\hline \multicolumn{1}{|c|}{ Categorial Inicial } & \multicolumn{1}{|c|}{ Resultado da Categoria Inicial } \\
\hline \multicolumn{1}{|c|}{ Aspectos Dificultadores } & \multicolumn{1}{|c|}{ Aspectos Dificultadores } \\
\hline $\begin{array}{l}\text { "[...] dispersão territorial dos servidores, diferenças } \\
\text { de relações entre chefias". (F05) }\end{array}$ & $\begin{array}{l}\text { "Todos os problemas [...] que contribuem para } \\
\text { dificultar o sistema de trabalho em equipe". (M14) }\end{array}$ \\
\hline $\begin{array}{l}\text { "Todos os problemas [...] que contribuem para } \\
\text { dificultar o sistema de trabalho em equipe". (M14) }\end{array}$ & \\
\hline
\end{tabular}

Fonte: elaborado pela autora, a partir dos dados da pesquisa em 2015

Os entrevistados F05 e M14 relatam "problemas que dificultam o trabalho em equipe e com as chefias", como aspecto dificultador dos trabalhos a serem realizados pela comissão. A esse respeito, Passos (2010:30) observa que

somente numa sociedade igualitária, onde os indivíduos tenham os mesmos direitos de participar das decisões e das execuções dos projetos sociais, onde o trabalho seja desenvolvido cooperativamente por todos, onde a marginalidade e o preconceito sejam abolidos, será possível o desenvolvimento de uma moral cujos os valores sejam representativos de todos os indivíduos e a vida humana seja respeitada em todos os sentidos. [grifo nosso] 
Do exposto, verifica-se que problemas irão continuar acontecendo, haja vista a sociedade atual não ser igualitária, conforme revela a autora. Entretanto, deve-se buscar soluções, e uma delas é a educação para a ética, seguida da conscientização de tais valores para o alcance de uma vida mais harmônica, seja no trabalho ou em qualquer outro campo da vida.

Outros aspectos foram levantados pelos respondentes, mas, como apresentaram só uma ocorrência, foram excluídos da segunda triagem no quadro das categorias iniciais. Ex: 'diversidade da UnB', 'cultura do jeitinho da comunidade', 'pouca exposição organizacional', 'mistura da matéria ética e disciplinar'.

Quadro 47. Quadro Geral da terceira Subdimensão (Questão 5 - Dificultadores)

\begin{tabular}{|c|c|c|c|}
\hline $\begin{array}{l}\text { Subdimensão } \\
\text { De Estudo }\end{array}$ & $\begin{array}{c}\text { Categorias Iniciais } \\
\text { Trechos e Expressões } \\
\text { Compostas em Negrito }\end{array}$ & $\begin{array}{c}\text { Categorias } \\
\text { Intermediárias }\end{array}$ & Categorias Finais \\
\hline & Aspectos Dificultadores & $\begin{array}{c}\text { Aspectos } \\
\text { Dificultadores }\end{array}$ & \\
\hline \multirow{5}{*}{$\begin{array}{c}\text { Gestão da ética } \\
\text { em relações de } \\
\text { trabalho Brasil } \\
\text { (1994); Brasil } \\
\text { (2007); Brasil } \\
\text { (2008); } \\
\text { Bergamini e } \\
\text { Beraldo (2010); } \\
\text { Chagas (2010); } \\
\text { Matos (2008); } \\
\text { Passos (2010); } \\
\text { Puig (1988); e } \\
\text { Soares (2002) }\end{array}$} & $\begin{array}{l}\text { "Todos os problemas [...] } \\
\text { que contribuem para } \\
\text { dificultar o sistema de } \\
\text { trabalho em equipe". (M14) }\end{array}$ & $\begin{array}{l}\text { Problemas em } \\
\text { equipe }\end{array}$ & \multirow{5}{*}{$\begin{array}{l}\text { Os aspectos dificultadores são: } \\
\text { problemas em equipe, o número } \\
\text { elevado de servidores, a precariedade } \\
\text { do sistema normativo, e a falta de } \\
\text { apoio da Administração Superior é } \\
\text { registrada na falta de um local físico } \\
\text { para que o trabalho seja conduzido. }\end{array}$} \\
\hline & $\begin{array}{l}\text { "Administrar um trabalho que } \\
\text { envolve grande número de } \\
\text { servidores que compõe os } \\
\text { recursos humanos da UnB". } \\
\text { (F18) }\end{array}$ & Servidores & \\
\hline & $\begin{array}{l}\text { "Mais premente é falta de um } \\
\text { local físico, como uma sala } \\
\text { para que o trabalho seja } \\
\text { conduzido". (M20) }\end{array}$ & Local físico & \\
\hline & $\begin{array}{l}\text { "Precariedade do sistema } \\
\text { normativo, como um decreto } \\
\text { que enseja, em casos mais } \\
\text { sérios, a judicialização das } \\
\text { atividades", (M22) }\end{array}$ & $\begin{array}{l}\text { Precariedade do } \\
\text { sistema normativo }\end{array}$ & \\
\hline & $\begin{array}{l}\text { "Falta de apoio da } \\
\text { administração superior que } \\
\text { é fundamental". (F23) }\end{array}$ & $\begin{array}{l}\text { Falta de apoio da } \\
\text { Administração } \\
\text { Superior }\end{array}$ & \\
\hline
\end{tabular}

Fonte: elaborado pela autora, a partir dos dados da pesquisa em 2015 
Após analisar e interpretar os fragmentos de fala de todos os entrevistados, por meio da interpretação por palavras-chaves ou expressões compostas que emergiram das categorias iniciais, foram compostas as categorias intermediárias. A interpretação foi feita com base no que os autores afirmam no referencial teórico desta pesquisa. A categoria final é resultado das categorias anteriores, constituindo uma síntese das ideias apresentadas pelos entrevistados, e assim escrita de forma coerente e coesa para o entendimento geral. É importante salientar que a análise dessas categorias ajuda na compreensão da dimensão aqui tratada.

Abaixo, seguem as considerações dos teóricos, abordados no referencial teórico, sobre essa subdimensão de estudo.

De acordo com os autores Soares, 2002; Chagas, 2010; Bergamini e Beraldo, 2010; Matos, 2008; Passos, 2010; Brasil, 1994; Brasil, 2008; Brasil, 2007; Puig, 1998 esta subdimensão, numa perspectiva da ética, revela que, para que ocorra a Gestão da Ética, é necessário o exercício de quatro funções, as quais são consideradas como básicas para Soares (2002:17), que são “[...] normatização, educação, monitoramento e aplicação de sistema de consequências". Já Chagas (2010:73), em relação à função educação, diz que "a instrução sem educação e o desenvolvimento das qualidades profissionais sem a dimensão cívica podem produzir indivíduos ainda mais antidemocráticos que os sem estudo”.

Na visão desses dois autores, Soares (2002) e Chagas (2010), a educação é requisito essencial para a Gestão da Ética e para o desenvolvimento das qualidades profissionais. Já Bergamini e Beraldo (2010) apontam que deve-se cultivar, não só a técnica, mas também ter atenção e afeto pelas pessoas, caso se esteja realmente interessado em promover o desenvolvimento do indivíduo. Portanto, é necessário acreditar genuinamente nos 
potenciais do ser humano, bem como em sua motivação, para que o grandioso seja construído, do contrário o individualismo aniquilará a força para esta construção (MATOS, 2008).

Em relação a uma das quatro funções básicas para a Gestão da Ética, citadas por Soares (2002), a normatização, os servidores civis do Poder Executivo Federal dispõem do Código de Ética (Decreto ${ }^{\circ}{ }^{1.171 / 94), ~ e m ~ q u e ~ P a s s o s ~ m e n c i o n a ~ o ~ C o ́ d i g o, ~ p a r a ~ d e s t a c a r ~ o s ~}$ deveres do servidor público, a saber:

a Seção II do referido Código destina-se a explicitar os deveres do servidor público. Seu artigo XIV [...] enfatiza que o servidor precisa ser cortês, atencioso, cuidadoso e respeitoso com os usuários do serviço público. Também que é seu dever ser rápido, assíduo, reto, justo, leal e íntegro, escolhendo sempre a opção que for beneficiar o maior número de pessoas. Essa é, sem dúvida, uma orientação moral importante (PASSOS, 2010:160).

Por estar explicitado no referido Código, os deveres do servidor público, não há que se falar em prerrogativa discricionária. Nesse entendimento, Soares afirma que

\footnotetext{
a gestão da ética transita por um eixo bem definido. Em uma de suas pontas, temos os valores e princípios éticos que se deseja norteadores da administração pública. No meio as regras de conduta, um caminho prático para que os valores e princípios sejam observados. Na outra ponta a administração, que deve funcionar como um instrumento garantidor da eficácia dos valores e regras (SOARES, 2002:17).
}

A respeito do dever da administração em funcionar como um instrumento garantidor dos valores e regras apontados por Soares (op.cit.) é que entra o exercício das quatro funções básicas, citadas anteriormente pelo autor, em relação à normatização, a educação, o monitoramento, e por fim, a aplicação do sistema de consequências, que, no caso da Comissão de Ética, é a pena de censura ética, ou o monitoramento, através do ACPP Acordo de Conduta Pessoal e Profissional, em que o servidor é monitorado em seu comportamento, e, caso haja o descumprimento desse acordo, ele é apenado com a censura.

O Código de Ética (Decreto $n^{0} 1.171 / 94$ ) cita expressamente em seu texto, Capitulo I, Seção I, Das Regras Deontológicas do Código de Ética Profissional do Servidor Público Civil do Poder Executivo Federal, o que segue: 
o servidor público não poderá jamais desprezar o elemento ético de sua conduta. Assim, não terá que decidir somente entre o legal e o ilegal, o justo e o injusto, o conveniente e o inconveniente, o oportuno e o inoportuno, mas principalmente entre o honesto e o desonesto, consoante as regras contidas no art.37, caput, e $\$ 4^{\circ}$, da Constituição Federal (BRASIL, 1994).

Em relação à normatização, que é um dos aspectos facilitadores dos trabalhos da Comissão de Ética, haja vista o seu caráter imperativo, com força de lei, a Comissão dispõe dos seguintes normativos, ditos anteriormente neste trabalho, mas apenas para reforçar, haja vista serem aspectos facilitadores do presente estudo, da Resolução ${ }^{\circ}{ }^{\circ} 10$ de 29.9.2008, da Comissão de Ética da Presidência da República - CEP/PR, que estabelece as normas de funcionamento e de rito processual para as Comissões de Ética instituídas pelo Decreto $\mathrm{n}^{\mathrm{o}}$ 1.171, de 22 de junho de 1994, e disciplinadas pelo Decreto $\mathrm{n}^{\mathrm{o}} 6.029$ de $1^{\mathrm{o}}$ de fevereiro de 2007.

Esses normativos são o referencial necessário ao que se deseja do servidor, quanto ao seu comportamento ético. A UnB também dispõe das seguintes normas internas: Ato da Reitoria $n^{\circ} 1.377$, criado em 23.7.2008, que trata da instituição da Comissão de Ética da Universidade de Brasília, tendo como base o disposto no Decreto n ${ }^{\circ}$ 1.171/94 (ANEXO 1); Ato da Reitoria $\mathrm{n}^{\circ} 1.398$, de 1.8.2008 (ANEXO 2), que criou a Secretaria Executiva da Comissão de Ética, com base no disposto nos $\S \S 1^{\circ} \mathrm{e} 2^{\circ}$ do artigo $7^{\circ}$ do Decreto $\mathrm{n}^{\circ} 6.029$, de 1.2.2007; Regimento Interno da Comissão de Ética da UnB (ANEXO 3), de 13.11.2008, elaborado a partir da Resolução no 10/2008 da Comissão de Ética Pública da Presidência da República.

Apesar de a questão ética estar presente nas legislações oficiais, na prática, verifica-se que ocorre conflitos éticos no cotidiano da Administração Pública (Puig, 1988), o que reforça a necessidade de ações educativas que sejam eficazes para o cumprimento da 
normatização existente, haja vista a sociedade contemporânea vivenciar uma crise de valores (PUIG, 1988). Daí a necessidade de que a ética também seja discutida no campo institucional.

A literatura inglesa tem suscitado a ética institucional com o seguinte enfoque: tornar prático o discurso da ética por meio da Gestão da Ética. Assim, verifica-se uma preocupação com a maneira em que ela pode ser efetivada. De acordo com Crane e Matten, a Gestão da Ética, sob o contexto de uma organização:

What exactly it is that we mean by managing business ethics? Obviously managing any area of business, when there it is production, marketing, accounting, human resources, or any other function, constitutes a whole range of activities covering formal and informal means of planning, implementation and control (CRANE e MATTEN, 2010:185). ${ }^{3}$

Segundo os autores a gestão ética nos negócios adviria das várias ações formais e informais de planejamento, implementação e controle, em que a finalidade maior está relacionada à disseminação de forma eficaz, por isto o planejamento, e após o controle, para que toda esta gama de atividades a favor da gestão ética seja efetivada.

Crane e Matten revelam ainda que o código de ética é o instrumento que propicia a abordagem mais ampla para a gestão da ética e que explicita as condutas éticas desejáveis aos funcionários de uma organização, profissão ou indústria, conforme o que segue:

Codes of ethics-these are explicit outlines of what type of conduct is desired and expected of employees from an ethical point of view within a certain organization, profession, or industry. as probably the most widespread approach to managing business ethics (CRANE e MATTEN, 2010:186). ${ }^{4}$

Ainda em relação à importância da existência desses códigos, Viano (1977:75) esclarece que "la ley se convierte en el principal instrumento de dirección de la conducta

\footnotetext{
${ }^{3} \mathrm{O}$ que é que queremos dizer especificamente com a gestão ética nos negócios? É a gestão de qualquer área de negócio, na presença de produção, marketing, contabilidade, recursos humanos, ou qualquer outra função, compõe (É o conjunto) todo o conjunto de atividades que abrangem meios (medidas) formais e informais de planejamento, execução (implementação) e controle (tradução livre).

${ }^{4}$ Os códigos de ética - são esboços (parâmetros/orientações/linhas) explícitos (claros) de que tipo de conduta ética é desejada e esperada da parte dos funcionários dentro de uma determinada organização (estrutura), profissão ou indústria. Assim como provavelmente a abordagem mais difundida (propagada) da gestão ética nos negócios (tradução livre).
} 
humana" e segue fundamentando "de suerte que las acciones humanas permanezcan todas dentro de los limites debidos y consigan la satisfacción aquiescente de quienes la cumplen". Haja vista, segundo o autor, "la ética pública, que tiene em la sociedade su ponto de referencia y, en las leyes, su instrumento".

Portanto, depreende-se destas citações, que, para que haja o estabelecimento da ética, é necessário que haja o marco regulatório, e que o mesmo esteja positivado nos códigos, servindo, assim, de referência para as atitudes que deverão ser tomadas. Além desse importante instrumento de apoio à gestão ética nas organizações, Crane e Matten (2010:186) revelam que a prática do discurso da ética deve acontecer por meio de

\begin{abstract}
reporting/Advice channels. Gathering information on ethical matters is clearly an important input into effective management. Providing employees with appropriate channels for reporting or receiving advice regarding ethical dilemmas can also be a vital means of identifyng potential problems, and resolving then before them escalate and or become public. Some organizations have therefore introduced ethics hotlines or other forms or reporting channels specifically for employees to notify management of ethical abuses or ploblems and to seek help and guidance on solution. ${ }^{5}$
\end{abstract}

Esses canais de divulgação com vistas a prestar consultoria e soluções, nada mais objetivam, do que tornar disponíveis aos interessados os meios apropriados para relatar ou receber conselhos sobre tensões éticas. A instituição desses colegiados e suas medidas preventivas contribuem para a gestão de riscos, posto que a existência de uma política preventiva de Gestão da Ética possa evitar maiores gastos e aborrecimentos com sanções de ordem judicial, conforme explica Crane e Matten (2010:186):

Risk analysis and management. Managing and reducing risks has become one of the key components os business ethics management, not least because awareness of

\footnotetext{
5 Relatórios/Canais (vias/métodos) de aconselhamento. A coleta de informação sobre questões éticas é claramente um importante contributo para uma gestão eficaz. Fornecer aos empregados. canais (vias) apropriados(as) para relatar ou receber conselhos relacionados com dilemas éticos, pode ser também um meio vital de identificar potenciais problemas, e resolvê-los antes que eles se agravem ou que se tornem públicos. Por este motivo, certas (algumas) organizações criaram linhas diretas de ética ou outras formas ou canais de comunicação, para os funcionários poderem especificamente notificar (informar/relatar) a gestão (administração) na ocorrência de abusos (violações/desvios) éticos/as ou problemas e procurar ajuda e aconselhamento a respeito da solução. (tradução livre)
} 
potential reputational and financial risks has been one of the key drivers of increased attention to business ethics in recent year. As Alejo Jose Sison (2000) suggest, the language of risk assessment has enabled business ethics to "show its bite" by spelling out the risks that firms run by ignoring ethics, and measuring these risks in monetary terms, such as the fines, damages, and sanctions that courts can impose (CRANE e MATTEN, 2010:186). ${ }^{6}$

As declarações de Crane e Matten (2010) contribuem para o entendimento de como gerir a ética, e proporcionam maior suporte teórico ao tema proposto. Assim sendo, o estudo de ética é uma opção de aprofundamaento, pois acredita-se que se nasça com ela o poder de agir ou não eticamente, apesar de suas implicações.

\section{CONCLUSÃO}

Esta pesquisa objetivou avaliar a Comissão de Ética como prática educativa para o exercício da gestão ética e democrática na comunidade universitária da UnB. O trabalho foi realizado por meio de estudo de caso de natureza qualitativa. Os dados foram coletados por meio de entrevistas, documentos e pesquisa bibliográfica. Os objetivos específicos desta Dissertação nortearam as perguntas que perfizeram as dimensões e subdimensões deste estudo. Desse modo, chegou-se às seguintes conclusões.

Conclui-se que a compreensão da dimensão ética nas relações de trabalho foi alcançada com a classificação, feita neste trabalho, em categorias para o entendimento da

\footnotetext{
${ }^{6}$ Análise e gestão de risco. Gerenciar e reduzir os riscos tornou-se um dos componentes chave da gestão ética nos negócios. Particularmente a conscientização dos potenciais riscos financeiros e de reputação têm sido um dos principais motores da atenção redobrada na ética de negócios nos últimos anos. Como Alejo Jose Sison (2000) sugere, a linguagem da avaliação dos riscos permitiu a ética nos negócios "mostrar sua dentadura", ao especificar os riscos que as empresas correm ao ignorar éticas, e medir (avaliar) esses riscos em termos monetários, tais como multas, danos e sanções que os tribunais podem impor. (tradução livre)
} 
dimensão Gestão da Ética, conforme a análise de resultados. A compreensão dessa dimensão também ocorreu com as prescrições sobre as atribuições da Comissão de Ética, segundo os normativos, para a gestão ética da Universidade de Brasília.

O referencial teórico da pesquisa, bem como os dados coletados nas entrevistas, evidenciaram que os problemas relacionais influenciam significativamente nos objetivos das organizações e no estabelecimento da gestão ética e democrática, por isso a importância da dimensão ética nas relações de trabalho. Não se pode pensar em resolver tudo, nem tudo de uma só vez, com cartilhas ou regimentos determinados. É necessário realizar uma investigação, tal qual realizada aqui, para, então, identificar o problema e atuar com a solução específica para cada fragmento identificado. Esta compreensão da profundidade em que se pode dar à ética é apenas uma proposta de em um primeiro passo, tornar-se uma reflexão, e, quiçá, no segundo passo já possa se implementar mudanças, na oportunidade deste documento ser aceito pela Comissão de Ética da UnB.

Enxerga-se, portanto, que é possível apontar alternativas que visem solucionar os possíveis conflitos causadores de adoecimento em relações interpessoais, ocorridos na realidade contextual da Universidade de Brasília.

É fácil, portanto, desenvolver um processo de trabalho na Comissão de Ética?

A pesquisa demonstrou que inúmeros aspectos são facilitadores, desde a composição da equipe, os canais de comunicação utilizados, o local de trabalho voltado para educação e, ainda assim, a crescente importância do tema 'Ética' na sociedade. Tais facilitadores, no entanto, sugerem que para que haja a implementação de uma política educativa voltada para a conscientização ética, os problemas em equipe precisam ser minimizados, especialmente por conta do elevado número de servidores atuantes na Universidade de Brasília. É preciso também superar as objeções quanto ao sistema normativo, e a Comissão de Ética precisa 
receber maior apoio da Administração Superior. Esse apoio pode ser demonstrado especialmente com a destinação de espaço físico adequado para a melhor condução dos trabalhos.

Observa-se que, nessa tendência - de maior apoio da Administração Superior -, é possível buscar a implantação de instrumentos de Gestão da Ética. Tais instrumentos revelamse nos programas educativos que precisam ter maior apoio, uma vez que a pesquisa apontou para um pseudo apoio da alta administração da universidade, categoria 'Falta de Apoio da Administração Superior”, que é legítima para que as estratégias nas organizações tenham sucesso na implementação.

Nesse contexto, os instrumentos de educação ética institucional apontam para uma melhor divulgação do papel da Comissão de Ética, realização de 'palestras e seminários de grande expressão', conforme fala dos entrevistados. Dessa forma, é possível romper barreiras como a resistência das pessoas em participar dessas ações.

Por fim, recomendam-se, primordialmente, ações para a educação ética na Universidade de Brasília, como a elaboração de um material que possa ser utilizado nas ações educativas da UnB. A complementação dessa recomendação se dá com os instrumentos de Gestão da Ética levantados pela pesquisa bibliográfica nesse estudo, bem como com a definição de 'ética no ambiente laboral' dada pelos entrevistados.

A Comissão de Ética poderá favorecer um espaço universitário ético, mediando e resolvendo conflitos com estratégias educativas. Para isso, recomenda-se a teoria da Andragogia, estudada por Vogt (2007), como a melhor prática de ensino para adultos, posto que é dotada de princípios sobre a aprendizagem. Destaca-se que ela pode ser usada em paralelo com os princípios do modelo pedagógico - este dedicado às crianças. Ou seja, a 
Andragogia é a forma de atuar junto aos adultos, sem deixar que percam suas motivações no aprendizado.

Não há como promover um estabelecimento da Gestão da Ética, sem os devidos instrumentos e metodologias necessários para uma operacionalização e monitoramento de mecanismos de inserção e participação de todos que ali precisam de tais norteadores, no caso, dos servidores públicos que trabalham e passam suas vidas no contexto da Universidade de Brasília. Eis uma latente necessidade de se trabalhar a informação ética nas organizações, para que, assim, seja promovida a cultura ética organizacional. Qualquer tipo de prática contrária à ética se mostrará desfavorável ao meio, à comunidade, à sociedade, com prejuízo nelas mesmas e em todo tipo de relação - política, econômica, institucional, e mesmo, internacional.

Contribuíram para esta compreensão, os autores que perfizeram o referencial teórico, bem como os entrevistados, que são servidores da UnB, profissionais que trabalham com a questão disciplinar, e por perceberem de um contexto interno, são os mais capazes de identificar e sugerir tais atividades, bem como definições que poderão ser utilizadas para elucidar explicações sobre esta seara em cursos promovidos pela Comissão de Ética.

Todo o levantamento dos dados, sejam eles obtidos por pesquisa bibliográfica, documental ou por análise de conteúdo, contribuíram para a construção da resposta à pergunta inicial, a saber: “a constituição de uma Comissão de Ética contribui como prática educativa para o exercício da gestão ética e democrática na comunidade universitária da Universidade de Brasília?" Pode-se responder positivamente, haja vista essa contribuição ser legalmente uma de suas funções. Como a educação tem um caráter preventivo, a prática educativa dessa comissão supera sua função coercitiva, alcançando, dessa maneira, o exercício da gestão ética e democrática na comunidade universitária. Outra contribuição faz referência à missão 
institucional da UnB, em que a questão ética foi contemplada na missão e nos valores da Universidade de Brasília. Portanto, o presente estudo colabora para o cumprimento dessa missão.

Assim, a gestão ética é uma questão a ser explorada de forma contínua e constante, tendo por norte que as práticas educativas busquem o alcance desta gestão ética e democrática nas instituições, favorecendo um espaço universitário ético, mediando e resolvendo conflitos com estratégias educativas.

Em relação às recomendações acadêmicas, poderá ser feito um estudo sobre a necessidade de treinamento conceitual sobre ética, bem como avaliar dentro do conteúdo dos cursos ofertados pela PROCAP/DGP, se tem algum conteúdo de ética. Em sua ausência, urge que se forme parâmetros norteadores das melhores práticas.

Outra recomendação seria a de fazer um levantamento de toda a universidade, com amostra representativa entre técnicos e professores sobre a questão da ética, no sentido de como se discute a ética na UnB, desde a questão do plágio acadêmico até um objeto furtado de um servidor ou um tratamento discriminatório pelos inúmeros motivos, ou a supressão de pequenos atos que pensam ser possíveis de não causar mal nenhum, mas que contribuem para um quadro de más políticas.

\subsection{Proposta de Gestão da Ética na UnB}

O presente trabalho buscou oferecer elementos que transpusesse o estágio da teorização, pela formulação de um modelo que seja aplicável e, portanto, transformador. Tal modelo deve retratar uma organização que prioriza as relações humanas, assim como deve ser 
flexível, de modo a se estabelecer um ambiente ético e continuado. Para que seja eficaz, devese promover a integração do nível de direção e das lideranças, na promoção da melhor comunicação de forma a somar forças entre os membros das organizações, e assim atuar com um "pensamento lógico, e com relacionamentos harmônicos na formulação e condução das políticas corporativas, contudo agora, já como parâmetros éticos".

Para que assim seja, deve-se aplicar este modelo, levando-se em conta a cultura da organização, de forma que na implementação deste modelo os ambientes laborais estejam flexíveis e mais receptivos a novos condicionamentos e aceitação de novas políticas, sob o enfoque da ética. É, portanto, sempre necessário um trabalho de conscientização antes da implementação desta nova política [de ética]. É por isso que os enfoques proporcionados pela Andragogia se fazem importantes, no tratamento e prática educacional de adultos.

Quanto ao administrador, este possui grandes responsabilidades frente à universidade, devendo sempre compatibilizar a liberdade que possui como cidadão, com suas obrigações e responsabilidades de agente público, prestando um serviço para a coletividade, devendo, para a consecução de tais fins, observar preceitos éticos inseridos nos princípios e na lei, através das delimitações dos seus poderes e deveres, a fim de atuar segundo afirma Arruda (2007), de acordo com observância dos valores de igualdade, justiça, dignidade da pessoa humana, solidariedade, desenvolvimento integral de cada um e de todos, e na tentativa de contribuir para a criação de uma sociedade mais ética, equilibrada e justa a partir de suas decisões e /ou atuações administrativas.

A prática educativa, sob o enfoque da ética, transmite valores conscientizados da cultura corporativa, sob o princípio ético de uma educação contínua, onde a meta é a de inovar para crescer, para expandir os melhores resultados, e, portanto, alcançando também a 
preservação da qualidade das relações então implicadas no contexto organizacional. É conclusão deste trabalho que a educação deve caminhar lado a lado com a ética.

Por oportuno, apresentam-se alguns direcionamentos de trabalho como: a sugestão de ações resolutivas já mencionadas em estudos anteriores, iniciando-se pela práticas educativas formativas e informativas,

"em que as pessoas possam ter um espaço para que o assunto seja falado, entendido, discutido, de maneira que possam explicitar as situações que estejam ocorrendo, fazer frente a elas, contemplar em seus regimentos internos e códigos de ética, cláusulas contra o assédio e de proteção às vítimas" (PASSOS, 2010:139);

e, na concepção de uma renovação do ambiente organizacional, a sugestão de

- diagnose da situação empresarial;

- avaliação situacional preliminar;

- rodada de reflexões estratégicas;

- auditoria de cultura e clima organizacional/ética na empresa;

- fórum de reflexão estratégica com os gestores. O desafio da ética (para assim atender a "Integração da ética no discurso - divulgar a política de promoção da ética dos canais de comunicação interno e externo", conforme revela Mendes (2014:101), ao apresentar o quadro com os instrumentos de Gestão da Ética, elaborados pela OCDE, e tradução da autora.

- Comitê Estratégico de ética corporativa;

- Oficina de Liderança - como, em geral, as pessoas não foram treinadas para "pensar em equipe estrategicamente", é que se emprega a Andragogia como metodologia de aprendizado adulto (Matos, 2008). 
Outra proposta refere-se à solicitação, por meio do expediente ofício, para a reitoria, de integralização das atividades educativas da comissão, de conscientização da ética, em conjunto com outros departamentos da universidade, como, por exemplo: ouvidoria da Universidade de Brasília, Serviço de Informação ao Cidadão (SIC), Coordenação de Processo Administrativo Disciplinar (CPAD) e PROCAP/DGP - Coordenadoria de Capacitação e Educação do Decanato de Gestão de Pessoas, com vistas à realização de um trabalho educativo e preventivo, como relatado no decorrer deste trabalho.

A proposta citada de integralização das atividades educativas para a ética na UnB trará ganhos se implantada, não só do ponto de vista da economia em poder evitar custos provenientes de processos administrativos, mas também para o correto cumprimento da missão institucional da UnB. Outra vantagem faz referência ao fato que se os departamentos envolvidos diretamente com a questão disciplinar (CPAD, Ouvidoria e Secretaria da Comissão de Ética) estiverem juntos, em um mesmo espaço físico, apenas divididos por salas, o acesso do usuário será facilitado, em especial dos deficientes físicos, ao departamento competente para ingressar com a demanda.

A última proposta apresentada corrobora com a seguinte citação: “os empregados devem ser responsabilizados pela conduta ética por meio da gestão de desempenho e dos sistemas de recompensa" (ALMEIDA, 2007:69). No caso específico da UnB, propõem-se aqui, que um dos requisitos para que se obtenha a progressão por capacitação é a de que os servidores (professores e técnico-administrativos) participem de atividade de capacitação com utilização de ferramentas midiáticas com duração mínima de 30 horas.

Recomenda-se que essa última proposta seja apresentada ao Conselho Universitário da UnB (CONSUNI) para apreciação e deliberação, além de ser encaminhada pela Comissão de Ética à CEP/PR. Assim, com a recomendação de capacitação em ética, o 
servidor estudará o Código de Ética (Decreto $\mathrm{n}^{\circ}$ 1.171/94), bem como os demais assuntos relacionados à formação ética do indivíduo. Essa atividade também objetiva estimular a reflexão da conduta ética para a manutenção das boas relações interpessoais, o que poderá, inclusive, refletir no desempenho organizacional.

Outra sugestão já mencionada no trabalho diz respeito ao fato de que é possível qualquer instituição antever-se às auditorias externas e realizar sua própria auditoria interna. A ideia é a de renovação e mudança de atitudes, inclusivamente para o Regimento Interno da Comissão de Ética da UnB, onde ficaria instituído a contratação de uma auditoria interna de forma terceirizada, ocorrendo periódica e anualmente.

Por fim, revela-se que este trabalho é um esforço pela busca de uma construção andragógica que visa à afirmação de padrões éticos na gestão democrática da Universidade de Brasília, tornando indispensável esta contribuição. 


\section{REFERÊNCIAS}

ABRUCIO, Fernando Luiz. O impacto do modelo gerencial na administração pública: um breve estudo sobre a experiência internacional recente. Brasília: ENAP, 1997 (Cadernos ENAP, n. 10).

AGUIAR, Victor Rafael Laurenciano; MEDEIROS, Cláudio Melquiades. Entrevistas na Pesquisa Social: o relato de um grupo de foco nas licenciaturas. IX Congresso Nacional de Educação - EDUCERE. III Encontro Sul Brasileiro de Psicopedagogia. PUCPR, 26 a 29 de outubro de 2009.2 Disponível em: http://www.pucpr.br/eventos/educere/educere2009/anais/pdf/3041_1475.pdf > Acesso em: 12.9.2015.

AGUILAR, Francis J. A ética nas empresas: maximizando resultados através de uma conduta ética nos negócios. Rio de Janeiro: Zahar, 1996.

ALLEDI, Cid; QUELHAS, Osvaldo Luiz Gonçalves. A sustentabilidade das organizações e a gestão da ética, transparência e responsabilidade social corporativa. Universidade Federal Fluminense; LATEC - Laboratório de Tecnologia, Gestão de Negócios e Meio Ambiente; Escola de Engenharia - Centro Tecnológico; UFF - Universidade Federal Fluminense. Niterói: UFF, 2002.

ALMEIDA, Filipe Jorge Ribeiro de. Ética e desempenho social das organizações: um modelo teórico de análise dos fatores culturais e contextuais. Revista de Administração Contemporânea, vol. $11, \mathrm{n}^{\mathrm{o}} 3,2007$.

ALVES, Léo da Silva. Quanto custa um processo administrativo disciplinar? Disponível em: < https://http://www.sedep.com.br/?idcanal=24440> Acesso em: 16 jul. 2015.

AMARAL, Helena Kerr do. Desenvolvimento de competências de servidores na administração pública brasileira. Revista do serviço público, vol. 57, nº 4, 2014.

AMORIN, Sônia Naves David. Ética na Esfera Pública: a busca de novas relações Estado/Sociedade. Revista do Serviço Público, Ano 51, nº 2, abr-jun., 2000.

ARRUDA, Alex Souto. José. A Terceira Revolução Educacional: a Educação na Sociedade do Conhecimento. São Paulo: Moderna, 2007. 
AZEVEDO, Carolina Valença et al. Cyberbullyng-Agressão Diginal na Rede: por quais circunstâncias andam a amorosidade e o respeito na educação? Poiesis Pedagógica. vol. 9, $n^{\circ}$ $2,2012$.

BARDIN, Laurence. Análise de conteúdo. Lisboa: Edições 70, 1977.

BDTD - Biblioteca Digital Brasileira de Teses e Dissertações; - IBICT - Instituto Brasileiro de Informação em Ciência e Tecnologia. 2015. Disponível em: < bdtd.ibict.br/vufind/Contents/Home?section=what > Acesso em: 11.8.2015.

BERGAMINI, Cecília Whitaker; BERALDO, Deobel Garcia Ramos. Avaliação de desempenho humano na empresa. 4. ed. São Paulo: Atlas, 2010.

BERnARDES, José Francisco. As Políticas de Recursos Humanos e suas Influências na Gestão Universitária. Florianópolis: UNTREF - Centro Cultural Borges, 2003.

BILHIN, J. Ciência da Administração. Lisboa: Universidade Aberta, 2008.

BILHIM, JOÃO A. F; GONÇALVES, Andréa. Casos de Ensino em Administração Pública Brasil e Portugal. Vol. 1. São Paulo: Atlas, 2012.

BITTAR, Eduardo C.B. Curso de ética jurídica: ética geral e profissional. 12.ed. São Paulo: Saraiva, 2010.

BIZERRA, André Luiz Villagelim. Governança no setor público: a aderência dos relatórios de gestão do Poder Executivo municipal aos princípios e padrões de boas práticas de governance. Dissertação (Mestrado em Ciências Contábeis). Rio de Janeiro: Faculdade de Administração e Finanças, Universidade do Estado do Rio de Janeiro, 2011.

BOBBIO, Norberto; NOGUEIRA, Marco Aurélio. O futuro da democracia: uma defesa das regras do jogo. Rio de Janeiro: Paz e Terra, 1997.

BONY, V; QUARESMA, S. J. Aprendendo a entrevistar: como fazer entrevista em ciências sociais. Revista eletrônica dos Pós-Graduandos em Sociologia Política da UFSC. Vol. 2 n ${ }^{\circ} .1$ (3) jan.-jul./2005. Disponível em: < https: //periódicos. UFSC.br/ index.php/emtese/ article/view/18027/16976 > Acesso em: 20.9.2015.

BORGES-ANDRADE, Jairo E. et al. Treinamento, desenvolvimento e educação em organizações e trabalho. Porto Alegre: Artmed, 2006.

BORGES, Cândido et al. Comissão de Ética Setorial: os desafios de fazer cumprir a ética na administração pública federal. Revista do Serviço Público - RSP, Vol. 61, n ${ }^{0}$ 2, Abr/Jun 2010 .

BRAGA, Nice. O Processo Decisório em Organizações Brasileiras. Revista Administração Pública, Rio de Janeiro, vol.3, nº 21, jul./set. 1987.

BRASIL. Governo Federal. LAI: A Lei de Acesso à Informação. Acesso à Informação. 
2015. Disponível em: <http://www.acessoainformacao.gov.br/assuntos/conheca-seu-direito/alei-de-acesso-a-informacao > Acesso em: 20.9.2015.

BRASIL. Presidência da República. Comissão de Ética Pública. Disponível em: < http://etica.planalto.gov.br/ > Acesso em: 20.10.2015.

Constituição (1988). Constituição da República Federativa do Brasil: promulgada em 05 de outubro de 1988. Diário Oficial da União, Brasília, 5 out. 1988.

Decreto $\mathrm{n}^{0}$ 1.171, de 22 de junho de 1994.Diário Oficial da União. Poder Executivo, Brasília - DF, 23 jun. 1994.

. Decreto $\mathrm{n}^{\mathrm{o}} 6.029$, de $1^{\circ}$ de fevereiro de 2007. Diário Oficial da União. Poder Executivo, Brasília - DF, 2 fev. 2007.

Lei $\mathrm{n}^{\circ}$ 9.394, de 20 de dezembro de 1996. Diário Oficial da União. Poder Executivo, Brasília -, DF, 23 dez. 1996.

Resolução n ${ }^{\circ}$ 10, de 29 de setembro de 2008. Comissão de Ética Pública (CEP). Diário Oficial da União. Poder Executivo, Brasília - DF, 29 set. 2008.

1. fev. 1967.

Decreto-Lei n ${ }^{\circ}$ 200/1967. Diário Oficial da União. Poder Executivo, Brasília, DF,

CALURI, Lucas Naif. Ética profissional e processual. Cadernos de Direito, vol. 6, $\mathrm{n}^{\mathrm{o}} 11$, 2011.

CAMARGO, Eder Pires de. Ensino de Ciências e Inclusão Escolar. Universidade Estadual Paulista "Júlio de Mesquita Filho" - UNESP. A análise de Conteúdo. Definição para a Realização de uma Análise Categorial. Campus de Bauru, 2015. Disponível em: < http://www2.fc.unesp.br/encine/teseeder/a+analise+de+conteudo+definicao+e+criterios+para +a+realizacao+de+uma+analise+categorial.php > Acesso em: 12.9.2015.

CAMPOS, Gecielda de Souza. O enfoque da gestão democrática da escola no canal educativo TV escola. Dissertação [Mestrado] Programa de pós-graduação em Educação. Brasília: UnB, 2007.

CAPES. Garantindo a fidedignidade dos dados da pós-graduação. Banco de Teses, 25.2.2011. Disponível em: < http://bancodeteses.capes.gov.br/noticia/view/id/1 > Acesso em: 11.8.2015.

CARDOSO, Onésimo de Oliveira. Comunicação empresarial versus comunicação organizacional: novos desafios teóricos. RAP, vol. 40 n ${ }^{\circ}$ 6. Rio de Janeiro, nov./Dez., 2006. Disponível em: < http://www.scielo.br/pdf/rap/v40n6/10.pdf > Acesso em: 20.8.2015.

CARMO, Suzana J. de Oliveira. Serviço Público: exigência de qualidade e eficiência "versus" adversidade do sistema. DireitoNet, 6.4.2004. Disponível em: 
$<$ http://www.direitonet.com.br/artigos/exibir/1528/Servico-publico-exigencia-de-qualidade-eeficiencia-versus-adversidades-do-sistema > Acesso em: 20.10.2015.

CARNEIRO, João Geraldo Piquet et al. Encontro entre meios e fins. A experiência da comissão de ética pública. Comissão de Ética Pública. Brasília: Secretaria Executiva, 2002.

CHAGAS, Júlia Chamusca. Psicologia escolar e gestão democrática: uma proposta de atuação em escolas públicas de educação infantil. Dissertação [Mestrado] Programa de pósgraduação em Processos de Desenvolvimento Humano e Saúde. Brasília: UnB, 2010.

CORTELlA, Mário Sérgio. Entrevista ao Programa do JÓ: o que é ética. 18.3.2013. Disponível em: <https://www.youtube.com/watch?v=vjKaWlEvyvU > Acesso em: 15.10.2014.

ética. Petrópolis: Vozes, 2013.

COSTA, Wellington Soares da. Humanização, Relacionamento Interpessoal e Ética. Caderno de Pesquisas em Administração. vol. 11, nº 1, São Paulo, Janeiro/Março, 2003.

CRANE, Andrew; MATTEN, Dirk. Business ethics: Managing corporate citizenship and sustainability in the age of globalization. Oxford: Oxford University Press, 2010.

DALFOVO, Michael Samir; LANA, Rogério Adilson; SILVEIRA, Amélia. Métodos quantitativos e qualitativos: um resgate teórico. Revista interdisciplinar cientifica aplicada. Vol. $2 \mathrm{n}^{\mathrm{o}}$ 4, Blumenau, Sem. II, 2008.

DE LA TAILLE, Yves. Formação ética: do tédio ao respeito de si. Porto Alegre: Artmed, 2009.

DEWEY, John. Democracia e educação breve tratado de philosofia de educação. Bibliotheca Pedagogica Brasileira. $3^{\text {a }}$ Série. Actualidades Pedagogicas. vol. 21. [Trad. Godofredo Rangel e Anísio Teixeira]. São Paulo: Companhia Editora Nacional, 1936.

ESCOLA NACIONAL DE ADMINISTRAÇÃO PÚBLICA - ENAP. Navegação Produção Científica: teses e dissertações por data. Repositório Institucional, 2015. Disponível em: < repositório.enap.gov.br/handle/1/94/browse?type=dateissued > Acesso em: 11.8.2015.

FARIAS, Vanderlei de Oliveira. Curso de gestão e apuração da ética pública: ética filosófica fundamentação filosófica da ética no serviço público. Brasília: Presidência da República, 2013.

FARIA, Maria de Fátima Bruno de; ALENCAR, Eunice M.L. Soriano de. Estímulos e barreiras à criatividade no ambiente de trabalho. Revista de Administração da Universidade de São Paulo, vol. 31, nº 2, 1996.

FIGUEIREDO, Vanessa da Silva; SANTOS, Waldir Jorge Ladeira dos. Transparência e Controle Social na Administração Pública. Faculdade de Administração e Finanças - FAF. 
Rio de Janeiro: UERJ, 15.1.2013. Disponível em: < http://www.trers.jus.br/arquivos/FIGUEIREDO_transparencia.pdf > Acesso em: 12.10.2015.

FISCHER, Rosa Maria et al. Desafios da atuação social através de alianças intersetoriais. Seminários em Administração da FEA-USP, vol. 6, 2003.

FONSECA, J. M. O paradoxo da inovação: necessidade de certeza num mundo imprevisível. Oeiras: Metáfora, 1997.

FREITAS, Maria Ester de. Por uma Ética na Demissão? RAE, vol 46, nº 1. São Paulo, 2006.

GALINDO, Camila José; INFORSATO, Edson do Carmo. Manifestações de necessidade de formação continuada por professores do $1^{\circ}$ ciclo do Ensino Fundamental. Dialogia, São Paulo, vol. 7, $\mathrm{n}^{\mathrm{o}}$ 1, 2008.

GAULEJAC, Vincent de. Gestão como Doença Social: ideologia, poder gerencialista e fragmentação social. [trad. Ivo Storniolo]. Aparecida/SP: Ideias \& Letras, 2007.

GONÇALVES, Maria Denise Abeijon Pereira. Ética na Administração Pública: algumas considerações. In: Âmbito Jurídico, Rio Grande, XIV, nº. 89, jun., 2011. Disponível em: < http://www.ambito-

juridico.com.br/site/?n_link=revista_artigos_leitura\&artigo_id=9538\&revista_caderno= $\underline{4}$ >. Acesso em: 10.10 .2015 .

GOMES, José Raimundo Pereira. O Processo Decisório na Administração Pública Brasileira e a Teoria das Organizações. Dissertação (Mestrado). Curso de Administração, Departamento de Administração da Faculdade de Estudos Sociais Aplicados. Brasília: UnB, 1999.

HOFSTEDE, Geert; HOFSTEDE, Gert Jan; MINKOV, Michael. Cultures and Organizations: Software of the Mind. $3^{\text {rd }}$ ed. USA: McGraw-Hill, 2010.

IYER, D. Ingraininghonesty, changingnorms: government ethics in Brazil, 1995 - 2004 Innovations for Successful Societies, Princeton University. 2013. Disponível em: < http://www.princeton.edu/successfulsocieties $>$ Acesso em: 10.10.2015.

JOHANN, Jorge Renato. Educação e ética: em busca de uma aproximação [recurso eletrônico]. Dados eletrônicos. Porto Alegre: Edipucrs, 2009.

JORDÃO, Clarissa Menezes. MARTINEZ, Juliana Zeggio. Fundamentos do texto em Língua Inglesa II. Curitiba: IESDE Brasil S.A., 2009.

KNOWLES. The modern practice of adult education: from pedagogy to andragogy. 2 ed. New York: Association Press, 1980.

KNOWLES. The adult learner: a neglected species. 2 ed. Huston: Gulf Publishing Company, 1978. 
KOBASHI, N. Y.; SANTOS, R. N. M. dos. Arqueologia do trabalho imaterial: uma aplicação bibliometria à análise de dissertações e teses. 2008. Disponivel em: http://www. periodicos.ufsc.br/index.php/eb/article/viewPDF. Acesso em 10/11/2015.

KUNSCH, Margarida Maria Krohling. Planejamento de Relações Públicas na Comunicação Integrada. 4 ed. São Pulo: Summus, 2003.

LAKATOS, Eva Maria; MARCONI, Mariana de Andrade. Fundamentos de pesquisa metodológica científica. São Paulo: Atlas, 2003.

LAS CASAS, Alexandre Luzzi. Administração de marketing: conceitos, planejamento e aplicações à realidade brasileira. São Paulo: Atlas, 2006.

LENZA, Pedro. Direito Constitucional esquematizado. 16 ed. São Paulo: Saraiva, 2012. LOPES, José de Sousa Miguel. Educação para a tolerância. $27^{a}$ Reunião. Minas Gerais: ANPEd, 2004.

MACIEL, Carlos Alberto Batista. Políticas Públicas e Controle Social: encontros e desencontros da experiência brasileira. In: X Congresso Internacional de Humanidades. Brasília: UnB, 2007.

MARTINO JÚNIOR, Randolpho. A Reforma Gerencial e o Controle Externo da Eficiência dos Gastos Públicos. JusBrasil, 2010. Disponível em: < http://martino-e-gomesadv.jusbrasil.com.br/noticias/2234200/a-reforma-gerencial-e-o-controle-externo-daeficiencia-dos-gastos-publicos > Acesso em: 12.9.2015.

MATOS, Francisco Gomes de. Ética na gestão empresarial. São Paulo: Saraiva, 2008 MATOS, Francisco Gomes de. Ética empresarial e responsabilidade social. Revista Recre@rte, $\quad \mathrm{n}^{\mathrm{o}} \quad 3, \quad$ junho, 2005. Disponível em: < http://www.iacat.com/revista/recrearte/recrearte03/etica_soc-empr.htm $>$ Acesso em: 20.10 .2015$.

MEIRA, Fabio Bittencourt. A ética empresarial em movimento: as (de) limitações do campo. Gestão \& Planejamento-G\&P, vol. 11, nº 1, 2010.

MENDES, Annita Valléria Calmon. Ética na administração pública federal: a implementação de Comissões de Ética Setoriais - entre o desafio e a oportunidade de mudar o modelo de gestão. Brasília: Fundação Alexandre de Gusmão, 2010.

MENDES, Annita Valléria Calmon. A administração pública e o sistema de gestão da ética: uma análise da política de promoção da ética no Poder Executivo Federal. Tese (Doutorado em Administração). Brasília: UnB, 2014.

MEZZAROBA, Orides; e, MONTEIRO, Cláudia Servilha. Manual de Metodologia da Pesquisa no Direito. 2.ed. São Paulo: Saraiva, 2004. 
MONTEIRO, Tânia. Dilma pede ética e eficiência aos servidores. Jornal Estadão de São Paulo, 2012. Disponível em: < http://www.estadao.com.br/noticias/nacional,dilma-pedeetica-e-eficiencia-aos- servidores, $952339,0 . \mathrm{htm}>$ Acesso em: 15.5.2014.

MORAES, Maria Regina Cariello. Gestão como Doença Social: ideologia, poder gerencialista e fragmentação social. (Resenha). Revista Brasileira de Saúde Ocupacional, vol. 37, $\mathrm{n}^{\mathrm{0}} 126$. São Paulo july/dec., 2012. Disponível em: < http://www.scielo.br/scielo.php?pid=S030376572012000200010\&script=sci_arttext > Acesso em: 20.9.2015.

MORAIS, José L. O. Ética e conflito de interesses no serviço público. Brasília: Esaf, 2009. Disponível em: < https://pt.scribd.com/doc/51407406/LIVRO-ET-1 > Acesso em: 10.10.2015.

MOTTA, Fernando Claudio Prestes. Cultura e organizações no Brasil. Relatório $\mathrm{n}^{0}$ 15/1996. Escola de Administração de Empresas de São Paulo. São Paulo: Fundação Getúlio Vargas, 1996.

NASEER, M.M; MAHMOOD. K. Use of bibliometrics, in Lis research. Library of Information Science Research Eletronic Journal vol. 19, n 2, sept. 2009.

PATRUS-PENA, R.; CASTRO. P.P. Ética nos negócios: condições, desafios e riscos. São Paulo: Atlas, 2010.

PASSOS, Elizete. Ética nas organizações. São Paulo: Atlas, 2010.

PECI, Alketa; PIERANTI, Octavio Penna; RODRIGUES, Silvia. Governança e New Public Management: convergências e contradições no contexto brasileiro. Organizações \& Sociedade, vol. 15, $\mathrm{n}^{\circ} .46,2014$.

PEREIRA, Luiz Carlos Bresser. Exposição no Senado sobre a Reforma da Administração Pública. In Cadernos MARE da reforma do estado; vol. 3., Ministério da Administração Federal e Reforma do Estado: Brasília, 1997.

PEREIRA, Matias José. Reforma do Estado e transparência: estratégias de controle da corrupção no Brasil. In: Congresso Internacional Del Clad sobre La Reforma Del Estado y de La Administración Píublica. nº 7, 2002, Brasília. Anais. Lisboa: CLAD, 2002.

PEREIRA. L. C. Bresser. Reforma do Estado e Administração Pública Garencial. Rio de Janeiro: FGV, 2003.

PINTO, Halley Ferreira. Gestão universitária e a política de informática: o caso do conselho de informática da Universidade de Brasília. Brasília: UnB, 2012.

PRODANOV, Cleber Cristiano; FREITAS, Ernani Cesar. Metodologia do trabalho científico: métodos e técnicas da pesquisa e do trabalho acadêmico. 2. ed. Novo Hamburgo: Feevale, 2013. Disponível em: <http://www.feevale.br/Comum/midias/8807f05a-14d0-4d5bb1ad-1538f3aef538/E-book\%20Metodologia\%20do\%20Trabalho\%20Cientifico.pdf> Acesso em: 22.8.2013. 
POLLITT, Christopher. Cuts and reforms - public services as we move into a new era. Society and Economy, 2010, v. 32, n.1, p. 17-31.

PUIG, Josep Maria. Ética e valores: métodos para um ensino transversal. São Paulo: Casa do Psicólogo, 1988.

RADIN, B. A. Os Instrumentos da Gestão Intergovernamental. Administração pública: coletânea. In: PETERS, G; PIERRE, J. (org.) Administração Pública. São Paulo: Unesp/Enap, 2010.

SALES, Jefferson David Araújo; SILVA, Patrícia Katiana da. Os fatores de resistência a mudança organizacional e suas possíveis resultantes positivas: um estudo de caso na Indústria-Calçados Bibi do Município de Cruz das Almas-BA. In: X SEMEAD. São Paulo: Universidade de São Paulo-USP, 2007.

SAMPAIO, Jáder dos Reis. O Maslow desconhecido: uma revisão de seus principais trabalhos sobre motivação. Revista de Administração da Universidade de São Paulo, vol. $44, \mathrm{n}^{\mathrm{o}} 1,2009$.

SANO, Hironobu; MONTENEGRO FILHO, Mário Jorge França. As Técnicas de Avaliação da Eficiência, Eficácia e Efetividade na Gestão Pública e sua Relevância para o Desenvolvimento Social e das Ações Públicas. Redalyc.org, Rio Grande do Sul, vol. 11, n . 22, 01 jan. 2013.

SILVA, Andréa de Oliveira. Amplitude de Participação da comunidade no Conselho Municipal de Saúde de Porto Alegre: a visão dos conselheiros. Porto Alegre, 1999. Dissertação (Mestrado em Administração) Escola de Administração, Universidade Federal do Rio Grande do Sul, 1999.

SILVA, Lindomar Pinto; FADUL, Élvia Mirian Cavalcanti. A Percepção dos Gestores Públicos Estaduais sobre o seu Papel na Implementação de Novos padrões de Eficiência na Gestão Pública: o gespública. Administração Pública e Gestão Social- APGS, Viçosa, vol. $3, \quad \mathrm{n}^{\mathrm{o}} \quad 2, \quad$ abr./jun. 2011. Disponível em: <http://www.apgs.ufv.br/index.php/apgs/article/view/63\#.U3jncaLeIyY>. Acesso em: 15.5.2014.

SILVA, Andressa Hennig; FOSSÁ, Maria Ivete Trevisan. Análise de Conteúdo: Exemplo de Aplicação da Técnica para Análise de Dados Qualitativos. Qualit@s Revista Eletrônica, vol. $1, \mathrm{n}^{\mathrm{o}} 1,2015$.

SILVA, Maria Júlia Paes da. O Papel da Comunicação na Humanização da Atenção à Saúde. Revista Bioética, vol 10, $\mathrm{n}^{\circ} 2,2009$.

SOARES, Luiz Miguel Pereira. A Ética na Administração Pública. Lisboa: Instituto Superior Ciências Sociais e Políticas, 2014. 
SOARES, Marcos Antônio Striquer. O Princípio Constitucional da Publicidade e Propaganda do Governo. In: Revista Jurídica da UniFil. Ano IV, $\mathrm{n}^{0}$ 4, 2007. Disponível em: < http://web.unifil.br/docs/juridica/04/Revista\%20Juridica_04-5.pdf > Acesso em: 12.8.2015.

SOARES, Mauro Sérgio Bogéa. Encontros entre meios e fins: a experiência da Comissão de Ética Pública. Brasília: Comissão de Ética Pública - Secretaria Executiva, 2002.

SOUZA, Flávia Cruz de. SIQUEIRA, Jean Francisco. A convergência da nova administração pública para governança pública: uma análise dos artigos internacionais e nacionais publicados entre 2000 e 2006. In: Congresso US Controladoria e Contabilidade em Prol do Desenvolvimento, ${ }^{\circ}$ 7. São Paulo, 2007.

SOUSA, Priscilla Kettilyn rosa de França; GONÇALVES, Andrea de Oliveira; ALVES, Elioenai Dornelles. O processo decisório nas Organizações e a sua Dimensão Ética”. Revista Eletrônica Gestão \& Saúde, Vol. 6, nº 01, 2015.

SOVIENSKI, Fernanda. STIGAR, Robson. Recursos Humanos X Gestão de Pessoas. Unidade de Ensino Superior Expoente. Gestão: Revista Científica de Administração e Sistemas de Informação. vol. 10, $\mathrm{n}^{\mathrm{o}}$ 10. Curitiba: Expoente, 2008.

TARAPANOFF, Kira (org.). Inteligência, Informação e Conhecimento. Brasília: Unesco IBICT, agosto de 2006. Disponível em: http://unesdoc.unesco.org/images/0014/001469/146980por.pdf >; Acesso em: 21.9.2015 TOLOV JUNIOR, José. Por que os programas de qualidade falham?. RAE-Revista de Administração de Empresas, vol. 34, n ${ }^{\circ}$. 6, 1994.

TREVIÑO, K. L.; BROWN, Michael E. Gestão ética. GV Executivo, vol. 4, nº 1, 2005. UNESCO - Building Peace in the minds of people. Representação da Unesco no Brasil. Disponível em: < http://www.unesco.org/new/pt/brasilia/ > Acesso em: 20.9.2015.

UNIVERSIDADE DE BRASÍLIA. O que é a Comissão de Ética. Entrevista com Marcel Bursztyn, Presidente da Comissão de Ética da Universidade de Brasília. UNBAGÊNCIA, 22.7.2011. Disponível em: < http://www.unb.br/noticias/unbagencia/unbagencia.php?id=5391 $>$ Acesso em: 12.11.2014.

UNIVERSIDADE DE BRASÍliA - UnB. Plano Anual de Capacitação, 2015. Decanato de Gestão de Pessoas. Diretoria de Capacitação, Desenvolvimento e Educação. Coordenadoria de Capacitação, $2015 \quad$ (a). $\quad$ Disponível em: ftp://ftp.unb.br/pub/download/DGP/Plano_Anual_de_Capacitacao_2015.pdf > Acesso em: 12.9.2015.

UNIVERSIDADE DE BRASÍLIA. A Ouvidoria da Universidade de Brasília. Ouvidoria, 2015 (b). Disponível em: < http://www.ouvidoria.unb.br/ > Acesso em: 20.9.2015.

UNIVERSIDADE DE BRASÍlIA, Ato da Reitoria n. 1.377, de 23 de julho de 2008. Brasília: UnB, 2008. 
UNIVERSIDADE DE BRASÍLIA, Ato da Reitoria n. 1.398, de 01 de agosto de 2008. Brasília: UnB, 2008.

UNIVERSIDADE DE BRASÍlLIA. Anísio Teixeira. 2015.Disponível em: < http://www.unb.br/administracao/reitoria/exreitores/anisio_teixeira > Acesso em: 20.10.2015.

UNIVERSIDADE DE BRASÍlla. Comissão de Ética. Disponível em: <

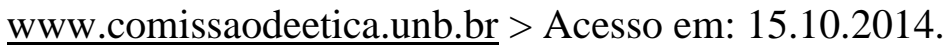

UNIVERSIDADE DE BRASÍLIA - UnB. Decanato de Planejamento e Orçamento. UnB em Números 2014. Disponível em: <http://www.dpo.unb.br/dados_institucional.php> Acesso em: 12.9.2015.

UNIVERSIDADE DE BRASÍLIA. Regimento Interno da Comissão de Ética da UnB, de 13 de novembro de 1998. Brasília: UnB, 1998. Disponível em: < http://www.comissaodeetica.unb.br/regimento-interno $>$ Acesso em: 15.10.2014.

UNIVERSIDADE DE BRASÍLIA - UnB. Repositório Institucional da UnB. 2015. Disponível em: < http://repositorio.unb.br/) > Acesso em: 11.8.2015.

VÁSQUEZ, Adolfo Sánches. Ética. Rio de Janeiro: Civilização Brasileira, 1975. . Ética. Rio de Janeiro: Civilização Brasileira, 1992.

VAZ, Henrique C. de Lima. Ética e justiça: filosofia do agir humano. Síntese: Revista de Filosofia, vol. 23, $\mathrm{n}^{\mathrm{o}} 75,2011$.

VERGARA, Sylvia Constant. Projetos e Relatórios de Pesquisa em Administração. 5. ed. São Paulo: Atlas, 2004.

VIANA, C. O Princípio da eficiência: a eficiente eficácia da administração pública. Revista da Faculdade de Direito da Universidade do Porto. n $^{\circ}$ VII Edição especial, Portugal, 2010.

VIANO, Carlos Augusto. Calábria. Barcelona: Labor, 1977.

VIEIRA, Liliane dos Santos. Pesquisa e Monografia Jurídica: na Era da Informática. 2.ed. Brasília: Brasília Jurídica, 2005.

VOGT, Maria Saletilock. Os princípios andragógicos no contexto do processo ensino aprendizagem em fisioterapia. Tese [Doutorado] Programa de pós-graduação em Ciências da Saúde. Brasília: UnB, 2007.

WAGNER, Linde. "Eu" e o" outro": executivos expatriados e itinerantes vivenciando uma nova realidade cultural no âmbito profissional e pessoal. Dissertação [Mestrado]. Universidade Federal do Rio Grande do Sul. Escola de Administração. Programa de PósGraduação em Administração. Rio Grande do Sul, 2009. 
YIN, Robert K. Estudo de caso: planejamento e métodos. [Trad. Daniel Grassi] 2.ed. Porto Alegre: Bookman, 2001.

A Inserção de Princípios Éticos na Formulação de Estratégias Empresariais. 14.8.2008. Disponível em: www.teses.usp.br/teses/disponiveis/12/12139/tde.../Texto_Dissertacao.pdf > Acesso em: 2.11.2015. 
ANEXOS 


\section{Ato da Reitoria n⿳1.377 (Anexo1)}

UNIVERSIDADE DE BRASILIA

ATO DA REITORIA N.1.377/2008

Institui a Comissăo de Ética da Universidade de Brasilia, e dá outras providéncias.

O PRESIDENTE DA FUNDAÇÃO E REITOR PRO TEMPORE DA UNIVERSIDADE DE BRASILIA, no uso de suas atribuiçbes e considerando o disposto no Decreto n. 1.171, de 22 de junho de 1994 - que "Aprova o Código de Ética Profissional do Servidor Público Civil do Poder Executivo Federal", especificamente os incisos XVI, XVIII, XXII e XXIV do Capitulo II,

\section{RESOLVE:}

Art. $1^{2}$ Instituir a Comissăo de Ética da Universidade de Brasília, vinculada ao Gabinete do Reitor, com caráter consultivo de dirigentes e servidores do âmbito desta Instituiçăo.

Art. $2^{2} \quad$ Fica a cargo da Comissáo de Ética da UnB orientar e aconselhar sobre a ética profissional do servidor da Instituiçá, no tratamento com as pessoas e com o património público, competindo-the conhecer concretamente de imputaçăo ou de procedimento susceptivel de censura.

Art. $3^{2} \quad$ A Comissăo de Ética incumbe fornecer, aos organismos encarregados da execuçăo do quadro de carreira dos servidores, os registros sobre sua conduta ética, para o efeito de instruir e fundamentar promoçōes e para todos os demais procedimentos próprios da carreira do servidor público.

Art. $4^{\circ} \quad$ A pena aplicável ao servidor público pela Comissăo de Ética é a de censura e sua fundamentaçăo constará do respectivo parecer, assinado por todos os seus integrantes, com ciência do faltoso. 


\section{UNIVERSIDADE DE BRASILIA}

Art. $5^{\circ}$ Para fins de apuraçăo do comprometimento ético, entende-se por servidor público todo aquele que, por força de lei, contrato ou de qualquer ato jurídico, preste serviços de natureza permanente, temporária ou excepcional, ainda que sem retribuiçăo financeira, desde que ligado direta ou indiretamente a qualquer órgăo do poder estatal, como as autarquias, as fundaçoes públicas, as entidades paraestatais, as empresas públicas e as sociedades de economia mista, ou em qualquer setor onde prevaleça o interesse do Estado.

Art. $6^{2} \quad$ Para cumprir plano de trabalho, a Comissăo de Ética contará com uma Secretaria-Executiva - vinculada administrativamente ao Gabinete do Reitor e tecnicamente à Comissăo - com funçăo precipua de prover o apoio técnico e material necessário ao cumprimento das atribuiçóes da Comissăo de Ética.

Parágrafo único. O plano de trabalho a que se refere o caput será elaborado pela Secretaria-Executiva e aprovado pela Comissăo de Ética, após análise e inclusăo de sugestớes pelos seus membros.

Art. $7^{2} \quad$ A Comissáo de Ética da Universidade de Brasilia será integrada por trés membros efetivos e trés suplentes, com mandato de um, dois e trés anos, na sua primeira composiçăo.

Art. $8^{e} \quad$ Este Ato entra em vigor nesta data.

Brasilia, 23 de julho de 2008.

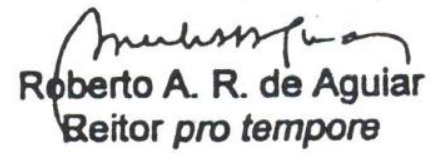

Cl cópia: Vice-Reitor, Decanos, todos os Centros de Custo. 
Ato da Reitoria n⿳1.398, de 1.8.2008 (Anexo 2)

\author{
UNIVERSIDADE DE BRASÍLIA
}

\author{
ATO DA REITORIA N.J398/2008
}

Cria a Secretaria-Executiva da Comissão de Ética da Universidade de Brasilia, e dá outras providências.

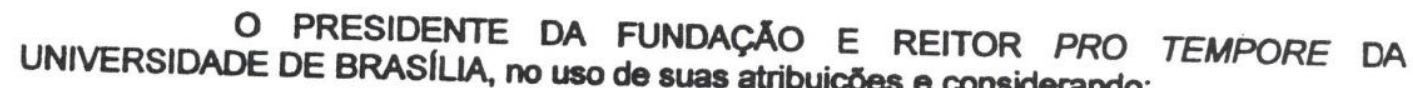
I. a instituiçăo da Comisa uso de suas atribuiçoes e considerando: Reitoria n. 1.377, de 23 de julho de 2008;

II. a constituiçăo da Comissăo de Ética da Universidade de Brasilia, por meio da cáo da Reitoria n. 58, de 23 de julho de 2008;

III. O disposto no $\$ 1^{2}$ e no $\$ 2^{2}$ do art. $7^{2}$ do Decreto n. 6.029 , de $1^{2}$ de fevereiro de 2007 - que institui Sistema de Geståo da Ética do Poder Executivo Federal,

\title{
RESOLVE:
}

Art. $1^{2}$ Criar, com vinculaçăo administrativa direta ao Gabinete do Reitor, a Secretaria-Executiva da Comissăo de Ética da Universidade de Brasilia.

Art. $2^{2}$ A Secretaria-Executiva tem como funçăo precípua prover o apoio técnico e material necessário ao cumprimento, pela Comissăo de Ética, de plano de trabalho.

Parágrafo único. O plano de trabalho a que se refere o caput será elaborado pela Secretaria-Executiva e aprovado pela Comissăo de Ética, após análise e inclusão de sugestőes pelos seus membros.

Art. $3^{0}$

A direçăo da Secretaria-Executiva ficará a cargo de servidor do Quadro de Pessoal Permanente da Fundaçăo Universidade de Brasília, que perceberá FG-1 do Gabinete do Reitor.

Art. $4^{2} \quad$ Este Ato entra em vigor nesta data.

$$
\text { Brasilia, } \text { j}^{\circ} \text { de aqustes de } 2008 .
$$

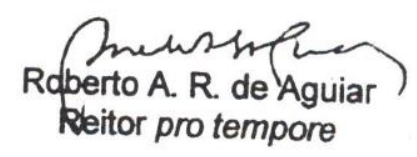




\section{Regimento Interno da Comissão de Ética da UnB (Anexo 3), de 13.11.2008}

\section{Capitulo I -Finalidade}

Este Regimento tem como finalidade regulamentar as disposições relativas à Comissão de Ética Setorial no âmbito da Universidade de Brasília, de acordo com o Código de Conduta do Servidor Público Civil do Poder Executivo Federal e no Decreto n. 6.029/2007; no que tange à competência, estrutura organizacional, atribuições, deveres e responsabilidades de seus membros, funcionamento e disposições gerais.

\section{Capitulo II - Composição e Estrutura Organizacional}

Art. $\mathbf{1}^{\mathbf{0}}$ - A Comissão será composta por três membros titulares e três suplentes, escolhidos entre servidores do quadro permanente de pessoal da Universidade de Brasília, designados pelo Magnífico Reitor, para mandatos de um, dois e três anos.

Art. $2^{\mathbf{0}}$ - Os membros da Comissão não perceberão remuneração de qualquer natureza pelo exercício da função.

Art. $\mathbf{3}^{\mathbf{o}}$ - A Comissão de Ética conta com uma Secretaria-Executiva, vinculada administrativamente ao Gabinete do Reitor e tecnicamente à Comissão.

Art. $4^{\mathbf{0}}$ - A Secretaria Executiva será chefiada por um Secretário-Executivo, integrante do quadro permanente de pessoal da Universidade de Brasília, nomeado pelo Magnífico Reitor.

\section{Capitulo III - Atribuições}

Art. $5^{\circ}$ - Aos membros da Comissão de Ética incumbe:

I - Ao Presidente:

a) convocar e presidir as reuniões da Comissão;

b) representar a Comissão;

c) dar execução às decisões da Comissão;

d) autorizar a presença nas reuniões de pessoas que, por si ou por órgãos/entidades que representem, possam contribuir na condução dos trabalhos da Comissão;

e) orientar e supervisionar os trabalhos do Secretário-Executivo; e

f) decidir os casos de urgência, ad referendum da Comissão.

II - Aos demais membros titulares:

a) examinar as matérias que lhes forem submetidas, emitindo parecer conclusivo e fundamentado;

b) solicitar informações a respeito de matérias sob exame da Comissão;

c) representar a Comissão, por delegação de seu Presidente;

III - Aos membros suplentes da Comissão, substituir os membros titulares em suas ausências;

IV - Ao Secretário Executivo:

a) organizar a agenda e a pauta das reuniões e assegurar o apoio administrativo e logístico à Comissão;

b) secretariar as reuniões;

c) proceder ao registro das reuniões e à elaboração de suas atas;

d) instruir as matérias submetidas à deliberação; 
e) providenciar a instrução de matéria para deliberação da Comissão, nos casos em que houver necessidade de parecer sobre a legalidade de ato a ser por ela editado;

f) manter a guarda dos processos depositados na secretaria da Comissão;

g) desenvolver ou supervisionar a elaboração de estudos e pareceres como subsídios ao processo de tomada de decisão da Comissão;

h) solicitar às autoridades submetidas ao Código de Ética, informações e subsídios visando à instrução de procedimento sob apreciação da Comissão;

i) elaborar anualmente relatório das atividades desenvolvidas pela Comissão.

\section{$\underline{\text { Capitulo IV - Funcionamento }}$}

Art. $6^{\mathbf{0}}$ - As deliberações da Comissão serão tomadas pelo voto da maioria simples de seus membros, cabendo ao Presidente o voto de qualidade.

Art. $\mathbf{7}^{\mathbf{0}}$ - As reuniões da Comissão ocorrerão, em caráter ordinário, mensalmente; e, extraordinariamente, quando necessário, por iniciativa de qualquer de seus membros.

Art. $8^{\mathbf{0}}$ - A pauta das reuniões da Comissão será composta a partir de sugestões de qualquer de seus membros, ou por iniciativa do Secretário-Executivo, admitindo-se, no início de cada sessão, a inclusão de novos assuntos.

Art. $9^{\circ}$ - O processo de apuração de infração ao Código de Ética será instaurado de ofício ou em razão de denúncia fundamentada, desde que haja indícios suficientes, e observado o seguinte:

I - notificação do servidor para manifestar-se, por escrito, no prazo de dez dias;

II - produção de prova documental ou testemunhal, destacando que:

a) a produção de prova poderá ser feita pelo manifestante ou pela própria Comissão;

b) a indicação de testemunhas será de, no máximo, quatro; podendo a Comissão, por intermédio de seu Presidente, indeferir pedidos de produção de provas considerados impertinentes, meramente protelatórios, ou de nenhum interesse para o esclarecimento dos fatos;

c) a Comissão, quando julgar necessário, poderá ouvir outras testemunhas além das indicadas;

d) sempre que possível, a Comissão ouvirá as testemunhas na mesma sessão.

$\S 1^{\circ}$ - O Secretário-Executivo, em suas ausências ou impedimentos, será substituído por um dos membros da Comissão, a ser designado pelo Presidente, mediante termo lavrado em ata.

$\S 2^{\circ}$ - O Secretário-Executivo submeterá anualmente à Comissão um plano de trabalho que contemple as principais atividades a serem desenvolvidas, propondo metas, indicadores e dimensionando os recursos necessários.

\section{Capitulo V - Competências}

Art. 10 - Compete à Comissão de Ética, no âmbito da Universidade de Brasília:

I - Zelar pelo cumprimento do Código de Ética Profissional do Servidor Público Federal e do Código de Conduta dos Servidores da Universidade de Brasília e submeter à Comissão de Ética Pública propostas para o aperfeiçoamento do referido Código;

II - Atuar como instância consultiva de dirigentes e servidores no âmbito da Universidade de Brasília;

III - Instaurar, de ofício ou a requerimento, processos éticos e aplicar a sanção cabível, conforme a sua competência; buscando precipuamente a prevenção de conflitos e a preservação da moralidade na Administração Pública; 
IV - Aconselhar sobre a ética profissional do Servidor Público no trato com pessoas e com o patrimônio público, com vistas ao fortalecimento da ética pública e ao restabelecimento da confiança nas instituições públicas;

V - Promover seminários, simpósios e outros eventos correlatos, que propiciem a difusão e a conscientização de condutas éticas;

VI - Orientar os servidores no sentido de adotar uma conduta conforme os princípios reitores da Administração Pública; inspirando o respeito pelos seus pares e pelo Serviço Público;

VII - Explicitar os desvios éticos e superá-los por meio de uma atuação positiva e pedagógica, buscando a prevalência da ética no contexto prático da Instituição;

VII - Conhecer, identificar e administrar os conflitos de interesses no âmbito da UnB; tendo como premissa básica a conscientização do Servidor Público;

IX - aplicar ao servidor público a pena de censura, exclusivamente, mediante parecer devidamente fundamentado, assegurando sempre o contraditório e a ampla defesa, e o caráter reservado em seus procedimentos;

$\mathrm{X}$ - fornecer à Secretaria de Recursos Humanos os registros sobre a conduta ética dos servidores da UnB, para efeito de instruir e fundamentar promoções e para todos os demais procedimentos próprios da carreira do Servidor;

XI - encaminhar a decisão e o respectivo procedimento de apuração de desvio de conduta ética à Comissão de Ética Pública da Presidência da República, para as providências pertinentes;

XII - propor Acordo de Conduta Pessoal e Profissional.

\section{Capitulo VI - Deveres e Responsabilidade dos Membros da Comissão de Ética}

Art. 11- Os trabalhos da Comissão devem ser desenvolvidos com celeridade e observância dos seguintes princípios:

a) proteção à honra e à imagem da pessoa investigada;

b) proteção à identidade do denunciante, se este assim o desejar;

c) independência e imparcialidade de seus membros na apuração dos fatos.

Art. 12 - Eventuais conflitos de interesse, efetivos ou potenciais, que possam surgir em função do exercício das atividades profissionais dos membros da Comissão deverão ser informados aos demais integrantes do Colegiado.

Parágrafo único. O membro da Comissão estará impedido de participar de procedimento envolvendo servidor ou autoridade com quem tenha relação de parentesco ou que lhe seja direta e hierarquicamente superior ou subordinado.

Art. 13 - As matérias examinadas nas reuniões da Comissão têm caráter sigiloso, ao menos até sua deliberação final, quando será decidida sua forma de encaminhamento e de normatização, por ementa.

Parágrafo único. Os membros da Comissão não poderão manifestar-se publicamente sobre situação específica que seja objeto de deliberação formal do Colegiado.

Art. 14 - O membro da Comissão deverá justificar, antecipadamente, a eventual impossibilidade de comparecer às reuniões, de modo a possibilitar a convocação tempestiva do respectivo suplente.

Capitulo VII - Das Disposições Gerais

Art. 15 - Estão sujeitos ao presente Regimento todos os membros desta Comissão. 
Art. 16 - No final de cada ano será realizada uma atividade de avaliação da consecução do planejamento adotado por esta Comissão.

Art. 17 - Caberá à Comissão de Ética da Universidade de Brasília dirimir as dúvidas e resolver os casos omissos decorrentes da aplicação deste Regimento.

Art. 18 - Este Regimento entra em vigor a partir desta data.

Brasília, 13 de novembro de 2008

Observação: O art. 90, inciso II, alínea "b" recebeu nova redação, por decisão tomada na Reunião de 05/08/2011. 


\section{APÊNDICES}




\title{
Apêndice A - Roteiro De Entrevista Estruturada
}

ROTEIRO DE ENTREVISTA ESTRUTURADA APLICADO AOS SERVIDORES DA UnB

\author{
UNIVERSIDADE DE BRASÍLIA \\ PROGRAMA DE PÓS-GRADUAÇÃO EM GESTÃO PÚBLICA
}

Prezados,

Convido-os a participar da presente pesquisa, que tem por objetivo avaliar a Comissão de Ética como prática educativa para o exercício da gestão ética e democrática na comunidade universitária da UnB. Toda a informação será tratada de maneira que assegure total sigilo. Agradeço a sua colaboração em fornecer as informações abaixo.

Sexo: Idade: Departamento:

Tempo de serviço nesse setor:

1- O que entende por ética nas relações interpessoais no ambiente laboral? Justifique

2- Você acha que a universidade apoia programas educativos para os servidores? Em caso positivo, como é dado esse apoio? 
3- $\quad$ Partindo da premissa de que a educação ética, de uma forma geral, propicia uma vida melhor para as pessoas, o que você acha que a Comissão de Ética pode fazer para transformar essa expectativa em realidade?

4- $\quad$ Em caso negativo, em que na sua opinião, seria impossível o desenvolvimento de um trabalho de conscientização da ética na UnB, quais os motivos que impediriam essa implementação?

5- Em que aspectos você considera como facilitadores e dificultadores do trabalho da Comissão de Ética na UnB? Justifique.

Mestranda Priscilla Kettilyn Rosa de França Sousa

Programa de Pós-Graduação em Gestão Pública - FUP/ UnB

Telefone: 8167-0177

E-mail: priscillafranca@unb.br 


\title{
Apêndice B - Termo De Consentimento Livre E Esclarecido
}

\author{
UNIVERSIDADE DE BRASÍLIA \\ PROGRAMA DE PÓS - GRADUAÇÃO EM GESTÃO PÚBLICA \\ Termo de Consentimento Livre e Esclarecido - TCLE
}

O (a) Senhor(a) está sendo convidado(a) a participar, como voluntário, em uma pesquisa que tem por objetivo avaliar a Comissão de Ética como prática educativa para o exercício da gestão ética e democrática na comunidade universitária da UnB. Leia cuidadosamente as informações a seguir. Este estudo está sendo conduzido pela Mestranda Priscilla Kettillyn Rosa de França Sousa, sob a orientação da Professora Doutora Andrea de Oliveira Gonçalves. Após ser esclarecido sobre as informações a seguir, no caso de aceitar fazer parte do estudo, assine ao final deste documento, que está em duas vias. Uma delas é sua é a outra é do pesquisador responsável. Em caso de recusa você não será penalizado (a) de forma alguma.

\section{ESCLARECIMENTO SOBRE A PESQUISA}

Título da pesquisa: “A Comissão de Ética como Prática Educativa: o Caso da Universidade de Brasília"

Pesquisador Responsável: Priscilla Kettilyn Rosa de França Sousa

Instituição/Departamento: Universidade de Brasília- UnB/ Programa de Pós-Graduação em Gestão Pública-FUP/UnB

Telefone para contato: (61) 8167-0177

A pesquisa tem como objetivo: Avaliar a Comissão de Ética como prática educativa para o exercício da gestão ética e democrática na comunidade universitária da UnB. Será garantido o acesso a pesquisa em qualquer etapa do estudo, você terá acesso aos pesquisadores responsáveis para esclarecimentos de eventuais dúvidas.

Se o senhor(a) concordar em participar do estudo seu nome e identidade serão mantidos em sigilo. Ressalta-se que a presente pesquisa não trará risco, prejuízo, desconforto ou lesões. Não existe para essa pesquisa indenizações ou forma de ressarcimento.

\section{Consentimento de participação da pessoa como sujeito}

$\mathrm{Eu}$ $\mathrm{RG} / \mathrm{CPF}$

abaixo assinado fui suficientemente informado sobre as informações que eu li sobre o presente estudo "A Comissão de Ética como Prática Educativa: o Caso da Universidade de Brasilía" e concordo em participar da pesquisa como sujeito. Ficaram claros para mim quais são os propósitos do estudo e procedimentos da pesquisa. Assim, concordo voluntariamente em participar deste estudo e poderei retirar o meu consentimento a qualquer momento, antes ou durante o mesmo, sem penalidade ou prejuízo.

Brasília, de de 2015.

Assinatura participante 


\section{Assinatura do pesquisador}

Declaro que obtive de forma apropriada e voluntária o Consentimento Livre e Esclarecido deste sujeito de pesquisa para a participação neste estudo.

Brasília, de de 2015 .

Priscilla Kettilyn Rosa de França Sousa Pesquisadora responsável 